\title{
Anales de Literatura Española
}

N.27, 20I5 (SERIE MONOGRÁFICA, I7)

\section{Hacia otra luz más pura (Memoria de Francisco Giner de los Ríos)}

Edición de Ángel L. Prieto de Paula

ElíAs Díaz Giner de los Ríos: la Institución como Ilustración

Nicolás Ortega CAnTero Francisco Giner y el descubrimiento moderno del paisaje de España

JuAn NAVARRo de SAn Pí «Tan práctico es pensar como cavar la tierra»: filosofía, educación y paisaje en Giner de los Ríos

AnTONio de Murcia Conesa «Un santo de corte hispánico»: Giner de los Ríos y el espectro del sujeto español

Ricardo Pinilla Burgos La idea de Crítica del arte en el pensamiento estético de Francisco Giner de los Ríos

FerRán Riesgo Martínez Reformismo, difusión y legado musical de Francisco Giner de los Ríos

Joaquín Juan Penalva Giner de los Ríos, crítico literario

Delia MANZANERo La competencia de la razón práctica en la conformación del humanismo gineriano

Ángel L. Prieto de Paula Panenteísmo y mística activa en «A don Francisco Giner de los Ríos», de Antonio Machado

José Luis González Geraldo \& Benito del Rincón Igea Francisco Giner de los Ríos o el arte de forjar almas

Raquel López SÁnchez Francisco Giner, estudiante de Bachillerato en el Instituto Jorge Juan de Alicante (una nota documental)

Adelina SiRvent GÁrriga La influencia de la Institución Libre de Enseñanza en Rodolfo Llopis

\section{ÁREA DE LITERATURA ESPAÑOLA}

DEPARTAMENTO DE FILOLOGÍA ESPAÑOLA,

LINGÜÍSTICA GENERAL Y TEORÍA DE LA LITERATURA

\section{Universidad de Alicante}



ANALES DE LITERATURA ESPAÑOLA 


\section{ANALES DE LITERATURA ESPAÑOLA}

\section{Director}

Enrique Rubio Cremades

Codirector

Miguel Ángel Lozano Marco

Secretaría académica

Eva García Ferrón \& Cristina Ros Berenguer

Secretaría técnica

Alexandra García MiLÁN

\section{Consejo editorial}

Carmen Alemany Bay (Universidad de Alicante)

Beatriz Aracil Varón (Universidad de Alicante)

Miguel Ángel Auladell Pérez (Universidad de Alicante)

M. ${ }^{a}$ Ángeles Ayala Aracil (Universidad de Alicante)

Jean-François Botrel (Université Rennes 2)

Helena Establier Pérez (Universidad de Alicante)

Jean-Pierre Étienvre (Casa de Velázquez)

José María Ferri Coll (Universidad de Alicante)

Dante Liano (Università Cattolica di Milano)

Renata LONDERo (Università degli Studi di Udine)

Gregorio Martín (Duquesne University)

Remedios Mataix Azuar (Universidad de Alicante)

Ermitas Penas Valera (Universidad de Santiago de Compostela)

Ángel L. Prieto de Paula (Universidad de Alicante)

Monserrat Ribao (Universidad de Vigo)

Juan A. Ríos Carratalá (Universidad de Alicante)

José Carlos Rovira Soler (Universidad de Alicante)

Diego Saglia (Università degli Studi di Parma)

Marisa Sotelo VÁzquez (Universidad de Barcelona)

Dolores Thion Soriano-Mollá (Université de Pau et des Pays de l'Adour)

Eva Valero Juan (Universidad de Alicante)

Comité científico

Joaquín Állvarez Barrientos (CSIC)

Francisco Javier Díez de Revenga (Universidad de Murcia)

Ana M. ${ }^{a}$ Freire López (UNED)

Salvador García Castañeda (Ohio State University)

Davis T. GIEs (University of Virginia)

José Manuel GonzÁlez Herrán (Universidad de Santiago de Compostela)

Yvan Lissorgues (Université de Toulouse-Le Mirail)

Francisco José Martín Cabrero (Università di Torino)

Piero Menarini (Università di Bologna)

César Oliva (Universidad de Murcia)

Leonardo Romero Tobar (Universidad de Zaragoza)

Santos Sanz Villanueva (Universidad Complutense de Madrid)

$(\dagger)$ Russell P. Sebold (University of Pennsylvania)

Philip W. Silver (Columbia University)

M. ${ }^{a}$ Carmen Simón Palmer (CSIC)

Adolfo Sotelo Vázquez (Universidad de Barcelona) 
ANALES DE LITERATURA ESPAÑOLA

Núm. 27 (2015). Serie MONOGRÁFicA, 17

ÁREA DE LITERATURA ESPAÑOLA

Departamento de Filología Española, Lingǘstica General y Teoría de la Literatura

UNIVERSIDAD DE ALICANTE

\section{Hacia otra luz más pura (Memoria de Francisco Giner de los Ríos)}

Edición de Ángel L. Prieto de Paula 
Los artículos publicados han sido evaluados por informantes externos, que en pares y de forma anónima han recomendado su publicación.

I.S.S.N.: 0212-5889

Depósito legal: A-537-1991

Maquetación: Marten Kwinkelenberg Impresión: Kadmos
Anales de Literatura Española se halla indizada en los índices RESH-CSIC y LATINDEX (catálogo). Asimismo, aparece recogida en las bases de datos de calidad PIO, ISOC y MLA. 


\section{HACIA OTRA LUZ MÁS PURA (Memoria de Francisco Giner de los Ríos)}

En Francisco Giner de los Ríos, de cuya muerte se han cumplido cien años en 2015, se concitan dos circunstancias singulares. La primera tiene que ver con el hecho de que su obra, diversa en los temas y de evidente aunque desigual interés, ha sido oscurecida por la ejemplaridad del autor como texto vivo, automática e inercialmente contrario a lo que se suele entender por «letra muerta» (o sea, por los artículos y libros). La segunda es relativa a la absorción que la persona ha sufrido por parte de la Institución Libre de Enseñanza, con todas sus derivaciones e hijuelas, hasta el punto de desaparecer en ella. Y si nos centramos en esta última faceta pedagógica, deberíamos matizar algo en lo que no siempre se repara: me refiero a que la influencia de la ILE no depende tanto de ella misma como de la que llamó López-Morillas eficacia reactiva que provocó o suscitó en las corporaciones educativas católicas o estatales: muchas de estas terminaron (¿paradójicamente?) incorporando buena parte de las propuestas de la Institución a la que se oponían, o a la que se les oponía, precisamente para cargarse de razones — del adversario- y poder así hacerle frente.

Y cabría añadir una tercera peculiaridad, si se quiere más lateral que las anteriores aunque muy poderosa en el imaginario colectivo (y el término «colectivo» no es de aplicación al común de la ciudadanía, sino al común, muy reducido, de quienes tienen algún conocimiento de nuestro hombre). Se trata de la semblanza moral de Giner de los Ríos que compuso Antonio Machado apenas informado de la muerte del maestro, primero en prosa y enseguida en verso, en un poema que terminaría incorporándose a las reediciones de Campos de Castilla: curiosamente, el poema pronto se convirtió en un retrato moral del homenajeante, Antonio Machado, que desplazó al homenajeado. ¿O hay muchos lectores que, cuando leen «A don Francisco Giner de los Ríos», pueden sustraerse a la idea de que en 
ese medallón se inscribe, junto a la de «don Francisco», una etopeya de «don Antonio»? Así, sobre la falsilla gineriana, se constituyó la conformación espiritual de Antonio Machado como «santo laico» que prevaleció en la posguerra y, a través de él, de un extendidísimo modelo de comportamiento ético.

Lo anterior se tradujo, incluso, en una formulación maniquea que llevó a establecer bandos poéticos y morales en el franquismo, enfrentados entre sí y encabezados respectivamente por Antonio Machado uno -ya no podía defenderse de sus «defensores»—, y por Juan Ramón Jiménez el otro. Uno enterrado, otro desterrado: ambos impotentes frente a su utilización simbólica. Uno, ejemplo del poeta civil y representante del pueblo; el otro, a quien se quiso ver encerrado en su urna de cristal, como poeta «turriebúrneo», y ello a pesar de su exilio. Lo cual es condenable no tanto por reductivo y maniqueo cuanto por mentiroso: ¡como si hubiera muchos españoles de ese tiempo más hermanados con don Francisco que Juan Ramón, y muchas obras más afectas al franciscanismo gineriano que Platero y yo! El librito estaba aún caliente de las prensas cuando murió Giner, quien en sus últimas Navidades regaló muchos Plateros, sin duda porque se reconocía en su aura estético-moral a pesar de estar trazada por mano ajena. «Con esta sencillez debía escribir usted siempre», le dijo el moribundo a Juan Ramón en la última visita que este le hizo. Y Juan Ramón también escribió su elegía a Giner. En todo caso, y volviendo a Antonio Machado, es bien hermoso el aludido fenómeno de transferencia desde el homenajeado al homenajeante, donde se cumple, aquí sí, la observación unamuniana de que el verdadero autorretrato lo traza uno en los retratos de personas a las que admira y con las que busca la identificación.

Todo lo cual ha terminado por emborrachar de color la imagen de Giner de los Ríos, que hoy, cien años después de su muerte, ha llegado el tiempo de repensar. Krausista de la generación de Gumersindo de Azcárate, Dorado Montero o Nicolás Salmerón, en su maestro Julián Sanz del Río encontró «no una filosofía, sino la filosofía», según afirmó Manuel Bartolomé Cossío, su sucesor en la dirección de la ILE. Y no deja de sorprender que Menéndez Pelayo, tan áspero con profetas de la novísima filosofía krausista como Sanz del Río, Nicolás Salmerón o Fernando de Castro, fuera contemporizador con don Francisco Giner, de quien resalta - como de los otros- la capacidad propagandística que le permitía «convertir en krausistas hasta las piedras», pero también —frente a alguno de los otros- su condición de «hombre honradísimo [...] y de buena fe». 
En este número de Anales de Literatura Española se pasa muy somera revista al Giner teórico del Derecho; al pedagogo que llevaba de su mano a niños y a hombres; al filósofo cuya línea de pensamiento debe perseguirse tanto en escritos propios como en la selección de autores a cuya traducción se aplicó; al tratadista de estética y musicología; al crítico literario; al «descubridor» moderno del paisaje; $y$, en fin, al texto vivo para cuyo conocimiento cabal haría falta haberlo tratado personalmente, pero que, pese a todo, se nos desvela con una nitidez asombrosa, además de en su obra escrita — que no, no es «letra muerta»—, en los juicios y evocaciones de sus contemporáneos y de sus discípulos.

Á. L. P. de P. 



\section{ÍNDICE}

Elías Díaz

Giner de los Ríos: la Institución como Ilustración

13

Nicolás Ortega Cantero

Francisco Giner y el descubrimiento moderno del paisaje de España

Juan Navarro de San Pío

«Tan práctico es pensar como cavar la tierra»: filosofía, educación y

paisaje en Giner de los Ríos

Antonio de Murcia Conesa

«Un santo de corte hispánico»: Giner de los Ríos y el espectro del

sujeto español

Ricardo Pinilla Burgos

La idea de Crítica del arte en el pensamiento estético de Francisco

Giner de los Ríos....

Ferrán Riesgo Martínez

Reformismo, difusión y legado musical de Francisco Giner de los Ríos ... 107

Joaquín Juan Penalva

Giner de los Ríos, crítico literario

Delia Manzanero

La competencia de la razón práctica en la conformación del

humanismo gineriano

Ángel L. Prieto de Paula

Panenteísmo y mística activa en «A don Francisco Giner de los Ríos», de Antonio Machado. 
José Luis González Geraldo \& Benito del Rincón Igea

Francisco Giner de los Ríos o el arte de forjar almas

Raquel López Sánchez

Francisco Giner, estudiante de Bachillerato en el Instituto Jorge Juan

de Alicante (una nota documental)

Adelina Sirvent Gárriga

La influencia de la Institución Libre de Enseñanza en Rodolfo Llopis

215

\section{RESEÑAS}

Gerardo Diego, Prosa musical, I: Historia y crítica musical

227

Rafael Alarcón, Vértice de llama: El Greco en la literatura hispánica (Estudio y antología poética) 233

Carmen Rivas Máximus, La literatura brasileña en España: recepción, contexto cultural y traductografía 237

Carmen Alemany Bay (coord.), Artes poéticas mexicanas. De los Contemporáneos a la actualidad 241

Alberto Santamaría, La vida me sienta mal: argumentos a favor del arte romántico previos a su triunfo 245

Cecilia Eudave, Diferencias, alteridades e identidad (Narrativa mexicana de la primera mitad del siglo $\mathrm{XX}$ )

Los autores 253

Normas para la presentación de originales 261 


\title{
GINER DE LOS RÍOS: LA INSTITUCIÓN COMO ILUSTRACIÓN
}

\author{
ELÍAS DÍAZ \\ Universidad Autónoma de Madrid
}

\section{Resumen}

La vinculación de Giner de los Ríos al krausismo y a la Institución Libre de Enseñanza no significa una reclusión en ellos. Su propuesta, que hunde sus raíces en la Ilustración, es la cara optimista o positiva (tesis) del 98 (antítesis), cuya síntesis sería la generación del 14, más científica y política. El pensamiento de Giner no es un pensamiento neutro ni una suma ecléctica carente de originalidad, pero tampoco debe contaminarse de los dogmas de un partido político o un credo religioso. Lo fundamental en él es la conjunción de ciencia y conciencia: racionalismo armónico (frente a los argumentos de autoridad); Estado laico; filosofía social de carácter organicista, que concede protagonismo a la sociedad civil; filosofía política de sentido liberal radical; economía con intervención social; educación como instancia fundamental para la transformación social; razón ética frente a razón instrumental.

Palabras clave: Giner de los Ríos; krausismo; Institución Libre de Enseñanza; racionalismo armónico; razón ética.

\begin{abstract}
Giner de los Ríos was not confined to Krausism and the Institución Libre de Enseñanza. His proposal, rooted in the Enlightenment, is the optimist or positive side (thesis) of the '98 (antithesis), the synthesis of which would be the Generation of ' 14 , more scientific and political. Giner's thought is not a neutral thought nor an eclectic sum lacking in originality, but neither should it be contaminated by the dogmas of a political party or religious creed. Its fundamental point is the conjunction of science and consciousness: harmonic rationalism (opposed to arguments from authority); secular State; social philosophy with an organicist character, conceding protagonism to the civil society; political philosophy of a radical liberal sense; economy with social
\end{abstract}


intervention; education as a fundamental instance towards social transformation; ethical reason, as opposed to instrumental reason.

Keywords: Giner de los Ríos; krausism; Institución Libre de Enseñanza; harmonic rationalism; ethical reason.

El punto de partida, génesis y conexión de fondo, es sin duda la recepción por Julián Sanz del Río (1814-1868) de la filosofía del alemán Karl Ch. F. Krause (1781-1832), a través de los discípulos de este en el histórico viaje de aquel a Heidelberg en 1843. Recepción, pues, de la filosofía krausista en nuestro país, proseguida por Francisco Giner de los Ríos (1839-1915) y la Institución Libre de Enseñanza creada por él en 1876. Pero bien en claro la relevancia de lo anterior, yo, a mi vez, vengo insistiendo hoy en la necesaria interpretación para nuestros días de un Giner «no reducido ni recluido».

No reducido ni siquiera a la escuela filosófica del krausismo; no recluido ni siquiera en la casa madre del paseo del Obelisco. En el breve espacio de este artículo, yo querría suscitar algunas ideas, proponer algunas líneas de interpretación, en relación con Francisco Giner de los Ríos, sobre la base de lo que todos conocemos ya sobradamente acerca de su pensamiento, de sus actitudes intelectuales, políticas y sociales. Sobre esa base me propongo sugerir, como digo, algunas consideraciones que puedan añadir algo más a todo este acervo común de conocimientos ${ }^{1}$.

Querría así recuperar principalmente la perspectiva de un Francisco Giner germinal o seminal, mucho más que terminal. Sin alterar lo fundamental, todos sabemos que resaltar unas cosas u otras implica también entender a los clásicos de una u otra manera. Cada tiempo lee a los clásicos destacando ciertos aspectos o poniendo de manifiesto unas características preferentes y dejando otras más en segundo lugar. Hablo, pues, de un Giner de los Ríos germinal, seminal, y no terminal, porque quiero sobre todo transmitir la idea de que aquel no se termina, no se agota, en ese mundo filosófico que conocemos muy estrictamente como krausismo. Desde ahí, sin embargo, sus aportaciones e influencia personal, su simiente institucionista, sus ideas básicas, van a posibilitar después, a lo largo del

1. Para mejor explicación y ampliación de estas páginas conmemorativas del centenario de la muerte de Giner, reenviaría a dos libros míos: uno, de 1973, La filosofía social del krausismo español (última ed., Madrid, Debate, 1989); otro, muy reciente, titulado De la Institución a la Constitución. Política y cultura en la España del siglo XX (Madrid, Trotta, 2009). 
siglo Xx y para nuestro tiempo también, el desarrollo en España con otra serie de direcciones intelectuales (positivismo, neokantismo, socialismo humanista) de algún modo derivadas germinalmente de aquel. La suya es una actitud, por tanto, germinal, origen de cosas nuevas que encontrarán amplia acogida social. Su pensamiento no va a significar un cierre, una terminación, el final del krausismo en el momento de su muerte, sino, a partir de ahí, un impulso renovador que va a desarrollarse críticamente, abiertamente, a lo largo del complejo y difícil siglo xx. Lo que quiero, en definitiva, resaltar es que Giner no es solo (ni principalmente) el último krausista, sino sobre todo el comienzo, con la Institución, de un decisivo renacimiento intelectual, científico y filosófico, de nuestro país.

Me detendré solo un momento en su recíproca influencia con el 98. En un esquema no distorsionante, creo, se podría decir que las posiciones del krausismo y la Institución Libre de Enseñanza representan el momento de la afirmación en el ámbito del pensamiento, la afirmación de la filosofía, el momento de la tesis, si se quiere. La generación del 98 sería en cierto modo el momento de la antítesis, de la duda, incluso de la negación, de la negatividad. La relación 98-Institución no es para nada una relación de continuidad sin más, lineal, sino una relación de oposición, de antítesis; pero la negación necesita siempre la afirmación previa - y esta de aquella- para poder avanzar y dar lugar a algún tipo de síntesis posterior. Están Giner y Unamuno en el mismo mundo, el de la modernidad, pero uno lo vive desde la armonía y otro desde la agonía.

En una reconstrucción un tanto demasiado resumida del pensamiento español del siglo Xx, señalaría, pues, que lo que representan Giner y la Institución es precisamente esa afirmación de una filosofía que enlaza directamente con la Ilustración. Atreverse a saber, atreverse a pensar libremente, hacer uso público de la propia razón. La Institución fue la Ilustración en España; una recepción tardía de la Ilustración, lo cual implicaba a su vez inconvenientes (patologías) y ventajas (conciencia del límite, mayor sentido histórico). Todo ello no era, por supuesto, algo privativo o exclusivo de España. Pero la recepción de la Ilustración no se realiza solo a través de la Institución. Lo que significa en España la generación del 98, el momento de la negatividad, es algo (¿Nietzsche, Freud?) que se produce en toda Europa en el fin de siglo. En este esquema, diría, con evidente abuso de la dialéctica (y de Hegel), que la generación del 14 y sus derivaciones podrían significar de alguna forma la síntesis de aquella afirmación y aquella negación. 
Ya sé que todo esto necesitaría muchas más precisiones de fondo y de detalle: y asumirlo, además, con espíritu crítico, y no dogmático. Pero pienso que puede ser útil para el debate esta perspectiva dialéctica del pensamiento español, de la filosofía española del siglo Xx, en la cual la negación fin de siglo se hace sobre la afirmación institucionista, y la síntesis viene representada por la generación del 14, más científica y política. Esta - recuérdese- también deriva directamente, pero a través de este proceso de negación y de afirmación, de los hombres que, gracias a la Junta para Ampliación de Estudios, han salido afuera a ampliar sus estudios y regresan a España en torno a estos años. La generación del 14, por lo tanto, Ortega y todo el grupo plural congregado en torno a la revista España, los que están tras la Liga para la Educación Política y todo lo que viene después, la generación del 27, la generación de la República, los socialistas como Besteiro o Fernando de los Ríos, son, de esa manera compleja y dialéctica, un derivado de Giner y del pensamiento ilustrado de la Institución. Pero - hago observar otra vez- nada de esto hubiera podido salir, ni explicarse, solo desde la influencia de Krause y del krausismo alemán. Hay también mucho del mejor Kant en las tareas y creaciones de la Institución.

Pero vendría en seguida la guerra (in)civil y la condena por el fascismo católico de los «sin patria y sin dios» de la nefanda Institución. Hubo después que recuperar todo esto, a partir de los años cincuenta y sesenta, fundamentalmente. El resto, hasta hoy, es ya nuestra historia, quiero decir la de las generaciones de los jóvenes del 56 y del 68 frente al franquismo para llegar a 1978. Sin forzar esas líneas críticas y dialécticas de nuestra reciente historia, me parece, no obstante, que desde ahí y andando el tiempo puede establecerse también en nuestros días un nexo claro entre Institución y Constitución. Yo he hablado, en este sentido, y en más de una ocasión, de un siglo de pensamiento liberal y democrático en España, en resistencia ante la persecución, comprendiendo ese largo y difícil tiempo que va desde 1876 a 1978 bajo el arco común de la Institución a la Constitución.

Esta perspectiva germinal, y no terminal, en la que estoy situando aquí mi interpretación implica también entender a Giner de los Ríos como no recluido ni reducido. Al decir «no recluido» quiero decir no recluido tampoco en el ámbito habitacional, a veces un poco estricto o estrecho, de la propia Institución Libre de Enseñanza. Hay, ha habido, un cierto regusto de un punto de vista interiorista que en vida ve a Giner de los Ríos (los que no somos institucionistas por herencia y tradición siempre lo sentimos así, como un tanto empequeñecido) según esa imagen doméstica de 
reclusión en esa casa, en la casa del paseo del Obelisco, hoy del General Martínez Campos, con don Manuel Bartolomé Cossío, con don Ricardo Rubio, rodeado en todo momento por las familias de unos y otros... Me parece bien, pero — icorríjanme los viejos institucionistas cuando les parezca oportuno! - creo que con ello se facilita una visión de Giner y de la Institución, como digo, excesivamente doméstica y recluida entre esos muros, en esa casa, lo cual impone también unos usos, unas rutinas, un cierto tipo de relaciones, hasta prejuicios y manías, con celos y enfrentamientos personales no precisamente muy atrayentes.

Me parece que esa reclusión no es buena ni verdadera. Pero, de hecho, alguna de las últimas biografías que se han escrito sobre Giner de los Ríos - una en concreto, diría yo, en verdad infame, con intencionada y total distorsión de su personalidad y su pensamiento- se ceba injustamente e incide con total exceso en esa perspectiva interiorista, en esa perspectiva de reclusión elitista, de grupo cerrado y sectario. Creo que todo ello empobrece gravemente el talante, la actitud personal y la amplitud social de los proyectos de aquel y del pensamiento mismo de la Institución. Más que la reclusión, lo que habría que destacar como fundamental y más cierto de su obra es - creo- la perspectiva de extensión. Recordemos justamente la famosa Extensión Universitaria y su acercamiento al pueblo con muy válidas propuestas de reforma. Y lo mismo en el campo del pensamiento: no una escuela cerrada en sí misma, sino abierta a las otras corrientes de la filosofía europea y española en el siglo Xx. Influye y es influida por lo mejor de esas filosofías, y con su recuperación tras los tiempos de persecución y silencio, asumiendo toda esa ilustrada tradición y la que está también presente en la obra de los exiliados republicanos, va a repercutir en el interior con buenas inspiraciones y aportaciones a la Constitución, que es tanto como decir, con todos sus problemas, a la democracia española actual.

Señalo, pues, que desde esa perspectiva germinal, no terminal, junto a ese Giner de los Ríos no recluido, hay también, decía, un Giner «no reducido». ¿No reducido a qué? Pues —esto es lo principal aquí- no reducido ni siquiera al krausismo. Como se sabe, «krausismo» fue el mote, el rótulo que, tras la recepción y difusión de Krause hecha por Sanz del Río, precisamente más utilizaron los adversarios integristas y ultramontanos para denominar e intentar denigrar, por foránea y extraña, esta filosofía. Por supuesto que nadie podría decir que Giner y los primeros institucionistas no fueron krausistas y que no tuvieron mucho que ver con Krause; eso, comparativamente, era hasta muy positivo. Pero yo insistiría, a mi 
vez, en que su amplio desarrollo y extensión posterior en nuestro país no se pueden reducir a ello. Por otro lado, asistimos hoy a una recuperación (incluso en Alemania) de Krause, mucho más importante de lo que se dijo en su tiempo y de lo que Menéndez Pelayo, que no lo conocía, dejó ya sentenciado como verdad dogmática. Reconociendo, pues, el pensamiento de Krause como base de esa filosofía, sobre todo en Sanz del Río, pero asimismo en Giner, aunque ya con otras influencias y exigencias, me parece - como digo- que no puede entenderse el reconocimiento de Giner y de las creaciones institucionistas (Junta para Ampliación de Estudios, Residencia de Estudiantes y tantas otras obras científicas y culturales hasta los años de la República) como si hubiesen sido producto de una mera aplicación de las ideas krausistas, de la filosofía de Krause. Es preciso, en consecuencia, no reducir absolutamente el hispánico institucionismo al germánico krausismo. En esa vía reencontramos entonces a un Giner germinal, no terminal, un Giner no recluido, no reducido: y con eso - creo- recuperamos al mejor Giner de los Ríos.

Tenemos buena base para ello. Recordemos un muy fundamental artículo de los Estatutos de la ILE que todos conocemos y que hemos leído con frecuencia, pero sobre cuyo fondo creo que no siempre se obtienen las adecuadas conclusiones. Decía así el artículo 15: «Esta Institución es completamente ajena a todo espíritu o interés de comunión religiosa, escuela filosófica o partido político». Por de pronto, completamente ajena a todo espíritu o interés de comunión religiosa: es decir, no se identifica la ILE con una religión, lo que defiende es el pluralismo religioso, la libertad de interpretación de la religión, incluso la posibilidad de su negación. Es decir, el mejor laicismo. Tampoco se identifica —ni se reduce, vengo subrayando aquí- con una escuela filosófica, ni siquiera, pues, con el krausismo, declaración de la cual habría que sacar las debidas consecuencias. Y obviamente la ILE no es un partido político. ¿Significa esto - como a veces extrañamente se ha querido interpretar- que Giner y la Institución tendrían un ideado, una concepción del mundo, sin implicaciones de ninguna escuela filosófica, de ninguna religión, de ningún partido político? En modo alguno cabe tal absurdo. ¿Sería un pensamiento neutro o, si se prefiere, completamente adiáforo, neutralista? Yo tampoco lo veo así en el sentido, sin más, de mero eclecticismo o, peor aún, de indiferencia respecto de valores éticos, políticos, intelectuales. De lo que se trata es de una filosofía que no es de una escuela, que no es de un partido, que no es de una comunión religiosa. Se señala allí, en la segunda parte de ese mismo 
artículo quince, que lo fundamental es la conciencia crítica y la ciencia, es decir, ciencia y conciencia: esto es, otra vez la Ilustración.

Me parece que aquí, en la conexión Ilustración-Institución, radica la base para entender mejor a Giner y para desvincularlo de esas y otras adscripciones dogmáticas y unilaterales. Pero nunca hay indiferencia neutral. Siempre que oigo hablar de neutralismo y neutralidad, me acuerdo de aquello de Unamuno cuando le interpelaban: «Don Miguel, usted en la próxima guerra civil será neutral, viendo cómo está criticando a unos y a otros». Y contestaba aquel: «No, no, jamás, yo no soy nunca neutral, porque neutral es neuter, ni con unos ni con otros»; es decir — añado yo-, con nadie, salvo con uno mismo. «Seré si acaso alterutral», añadía Unamuno, es decir, con unos y con otros, uniéndolos, fundiéndolos y confundiéndolos incluso. En alguno de mis libros me he ocupado más detenidamente de estas cuestiones y también de la no confusión, en el tema de la objetividad (mejor que de la neutralidad), entre las weberianas «referencia a valores» (Wertbeziehung) y «liberación de los juicios de valor» (Wertfreiheit). La referencia a valores es ineludible (ninguna realidad es adiáfora, valorativamente neutra, indiferente); pero hay que librarse de los juicios de valor que deforman u ocultan el conocimiento de la realidad. Me parece que esa filosofía de la Ilustración-Institución fue, y sigue siendo, buena guía para los mejores planteamientos y orientaciones del pensamiento español, que tiene a Francisco Giner de los Ríos como referente imprescindible.

¿Cómo especificar los principales caracteres de ese pensamiento? Casi telegráficamente, para terminar, pero reasumiendo todo lo anterior, cabe - creo- decir que lo que Giner de los Ríos y la Institución aportan al acervo común crítico de todo ese pensamiento español podría concretarse en los siguientes puntos (ya enumerados y desarrollados más detenidamente en esas publicaciones mías ya mencionadas aquí):

a. Una filosofía que ellos, desde Sanz del Río y el propio Giner, denominan racionalismo armónico: es decir, el reconocimiento de la razón frente a los argumentos de autoridad de la escolástica impuesta casi desde siempre en nuestro país, así como durante todo aquel tiempo y otra vez, con la guerra civil, hasta mucho después. Racionalismo armónico significa razón y experiencia, razón e historia, razón teórica y razón práctica... Me permitiría decir que aquí, además de Krause, hay también o casi más de Kant.

b. Una actitud religiosa — dejemos ahora al margen el famoso panenteísmo- de afirmación de la conciencia crítica, de la libertad 
religiosa, de un cristianismo racional o incluso de agnosticismo, siempre que todo ello sea asumido de buena fe y con buena conciencia. Es decir, un Estado laico.

c. Una filosofía social de carácter organicista — por tanto, no individualista, pero tampoco colectivista-, que ve la sociedad, el grupo social, como compuesto por asociaciones intermedias plurales. Puede señalarse que en esta filosofía social —no cité antes la conexión con la Constitución en vano- hay base para un entendimiento de la sociedad políticamente organizada en una situación cercana a lo que sería hoy en España el Estado de las autonomías e, incluso, un Estado federal. También debe haber base para la inclusión de los movimientos sociales, que articulan pluralmente en nuestro tiempo el conjunto de la sociedad civil.

d. Una filosofía política de sentido liberal radical. Como se ve, soy partidario de recuperar el término «radical». Nada que ver con su uso, como ocurre actualmente, como sinónimo de extremista o, incluso, de violento o terrorista. El autor de la biografía infame a la que me he referido antes cifra siempre su condena — «Giner es un radical»- en lo que para él constituye el peor de los males. Sí, yo creo que es un liberal radical, en el sentido de que va al fondo de lo que es la filosofía liberal, a sus raíces, que implican y exigen coherentemente una actitud democrática de verdad, la libertad para todos. Por eso diría que, aunque Giner — a finales del XIX - no es partidario explícitamente del sufragio universal, porque cree que no se dan todavía las condiciones para ello (su propuesta educativa general subsanaría con el tiempo esa deficiencia, piensa él), sin embargo, me parece que en ese liberalismo radical están potencialmente las bases de un liberalismo democrático que podría ir incluso bastante más allá (por ejemplo, la socialdemocracia de institucionistas como un Julián Besteiro o un Fernando de los Ríos). Se trata en todo caso de una filosofía política de, por lo tanto, oposición clara y rotunda a todo tipo de absolutismos, a todo tipo de dictaduras y totalitarismos, a todo tipo de tradicionalismo. Giner de los Ríos, como filósofo del derecho, es un hombre que postula expresamente a principios del siglo Xx un Estado de Derecho entendido ya como un Estado social de Derecho, y que además - y esto, digámoslo, sí que proviene más de Krause que de Kant- reclama, en consecuencia, los derechos sociales, los derechos de la mujer, los derechos del medio ambiente, de la ecología, 
de la paz, de la atención preferente a los niños, a los ancianos... Es decir, los derechos fundamentales que constituyen la base en nuestro tiempo del Estado social y democrático de Derecho. Dejemos esto apuntado aquí, como referencia, una vez más, a su presencia, junto a esas otras derivaciones democráticas, en la Constitución de 1978.

e. ¿Cuál y cómo es en esa concepción la función de la economía? Desde luego, no lo es el abstencionismo estatal y social que a veces se quiere unir inescindiblemente al pensamiento ilustrado. El laissez faire, laissez passer del liberalismo económico no es la respuesta en la perspectiva liberal radical (ética) de Giner y de la filosofía política de la Institución. Se propugna más propiamente un intervencionismo social, pero, por supuesto —y está bien—, nunca un exclusivo y excluyente intervencionismo estatal. Su intervencionismo público, social y estatal, con sector privado también, se ha visto asimismo como una vía de aproximación al socialismo democrático: eso será ya obra, como señalé, de Fernando de los Ríos o de Julián Besteiro, que tampoco son estatalistas, pero desde luego sí deja claro Giner que el liberalismo económico — hoy diríamos el «liberismo», paleoliberalismo o neoliberalismo conservador (neocon) — no es para nada lo más concorde con su pensamiento.

f. La ética y la educación como instancias más radicales para la transformación social. Se puede avanzar hacia ella a través del derecho, la política, la economía, es cierto, y más aún con la cultura, con la ciencia, con la moral de la ciencia, con el acercamiento a la ciencia europea... Pero todas esas dimensiones habrán de ser entendidas (no reducidas) no desde una razón instrumental (de medios), sino, otra vez la Ilustración, desde una razón de fines, una razón ética. Si, en consecuencia, falta la ética, y si falta la educación en sus valores fundamentales, los cambios lo serán solo en la superficie de las cosas. El resorte más radical de este ideario de Giner de los Ríos que he resumido aquí muy sucintamente es, pues, la ética y la educación. Formar hombres, caracteres, criterios: esa será su propuesta pedagógica en la ILE y en sus otros centros de educación. El saber y la virtud, la ética unida al conocimiento, teoría y práctica, ciencia y conciencia son la base de ese pensamiento. A ello dedicó su vida. Querría, en ese sentido, terminar recordando unas palabras de Giner, cuando en 1899, el año siguiente al Desastre, todo el mundo está debatiendo sobre qué hacer en este país 
después del 98. Habla así: «En los días críticos en que se acentúan el tedio, la vergüenza, el remordimiento de esta vida actual de las clases directoras, es más cómodo para muchos pedir alborotados a gritos una revolución, un gobierno, un hombre, cualquier cosa, que dar en voz baja el alma entera para contribuir a crear lo único que nos hace falta: un pueblo adulto».

Pienso que desde entonces, a pesar de todas las interrupciones y obstáculos que la historia (es decir, nosotros, los hombres y las mujeres) desgraciadamente hemos introducido en este proceso, resulta posible constatar que a la acción y al pensamiento de Giner de los Ríos y de todos quienes participaron en las diferentes instituciones y organismos derivados de la Institución Libre de Enseñanza se les debe reconocer en justicia la destacada aportación que han llevado a cabo para lograr que este país haya formado, diría yo (si no antropológicamente optimista, espero que algo realista), un pueblo relativamente adulto. $\mathrm{Y}$ al decir pueblo incluyo a todos. Las tareas presentes y futuras que tenemos ante nosotros serán la mejor medida y comprobación de la validez de este aserto que sigue siendo también para mí una muy firme esperanza. Incluso a la altura de este difícil año de 2015 en que conmemoramos, recordando siempre el poema de Antonio Machado, el centenario de su muerte.

Fecha de recepción: 22-4-2015

Fecha de aceptación: 12-10-2015 


\title{
FRANCISCO GINER Y EL DESCUBRIMIENTO MODERNO DEL PAISAJE DE ESPAÑA
}

\author{
Nicolás Ortega CANTERo \\ Universidad Autónoma de Madrid
}

\section{Resumen}

Francisco Giner de los Ríos (1839-1915), fundador en 1876 de la Institución Libre de Enseñanza, inició, en los últimos decenios del siglo XIX, un verdadero descubrimiento del paisaje de España. Planteó una nueva visión del paisaje español, que incorporó la perspectiva del paisajismo geográfico moderno, inicialmente promovido por Humboldt. Esta nueva perspectiva atribuyó a ese paisaje un conjunto de valores culturales que se consideraron expresivos de la propia historia y de la identidad colectiva o nacional derivada de ella. Giner y sus colaboradores de la Institución Libre de Enseñanza vieron en el paisaje español (y sobre todo en el paisaje de Castilla y la Sierra de Guadarrama) un verdadero símbolo nacional.

Palabras clave: Francisco Giner de los Ríos; paisajismo geográfico moderno; paisaje español; Castilla; Sierra de Guadarrama.

\begin{abstract}
Francisco Giner de los Ríos (1839-1915), a founder in 1876 of the Institución Libre de Enseñanza, initiated, in the last decades of 19th century, a true discovery of the landscape of Spain. He proposed a new vision of the Spanish landscape, which incorporated the perspective of modern geographical landscaping as pioneered by Humboldt. This new perspective attributed to that landscape a cultural value set that was considered reflective of the Spanish history and of the collective or national identity derived from it. Giner and his colleagues of the Institución Libre de Enseñanza understood the landscape of Spain (and especially the landscape of Castilla and the Sierra de Guadarrama) as a real national symbol.
\end{abstract}

Keywords: Francisco Giner de los Ríos; modern geographical landscape's view; Spanish landscape; Castilla; Sierra de Guadarrama. 


\section{Introducción}

Recuerda Alfonso Reyes, en uno de los breves relatos de sus Simpatías y diferencias, una noche de fin de año que pasó, con Américo Castro y Antonio Solalinde, en la Sierra de Guadarrama. Se alojaron en el chalet que tenía el doctor Madinaveitia, suegro de Castro, en El Ventorrillo, cerca de las primeras instalaciones serranas del Club Alpino Español. Al hilo de ese recuerdo, habla Reyes del importante papel que habían jugado Francisco Giner y sus colaboradores de la Institución Libre de Enseñanza en el descubrimiento de aquel paisaje montañoso y en el fomento de las excursiones, allí y en muchos otros lugares. Habían inaugurado en España «la tradición del amor a la naturaleza», y con ella se había desarrollado también, gracias a ellos, el «culto al Guadarrama», que contaba en los años veinte, cuando escribe Reyes su recuerdo, con «sacerdotes» como Ramón Menéndez Pidal o Enrique de Mesa. Y todo ello procedía en último término de la nueva actitud hacia la naturaleza y el paisaje que Giner había iniciado y promovido, desde los años ochenta del siglo anterior. «Supongo —escribe Reyes-que fue Francisco Giner de los Ríos el inventor del Guadarrama» (Reyes, 1956: 393).

Y no solo del Guadarrama. Puede decirse también, en términos generales, que Giner fue el inventor del paisaje de España, en la medida en que fue precisamente él quien introdujo y promovió un nuevo modo de verlo y valorarlo, abriendo así el camino de su descubrimiento moderno. Fue el hallazgo de algo nuevo, ignorado hasta entonces. Porque el paisaje, tal y como se entiende en el horizonte de la modernidad, no es solo materialidad, objetividad visible, sino también, al tiempo, elaboración cultural, imagen subjetiva apoyada en ideas y sentimientos. Para hacerse paisaje, lo visible necesita el concurso de la mirada, que juega, como ha señalado Jean-Marc Besse, un «papel constituyente» (Besse, 2010: 121). Y eso fue lo que aportó Giner por vez primera en España: la mirada de la modernidad paisajística, capaz de elevar lo visible a la categoría de paisaje. Esta fue la clave de su invención de la Sierra de Guadarrama y, yendo más allá, del paisaje de España. Veamos cómo se concretó y desenvolvió esa perspectiva paisajística de Francisco Giner ${ }^{1}$.

1. Las páginas que siguen se apoyan en buena medida en algunos trabajos anteriores del autor sobre el mismo asunto, entre los que se cuentan principalmente Ortega Cantero, 2001; 2007a; 2012. 


\section{La perspectiva del paisajismo geográfico moderno}

La mayor parte de la amplia labor de Francisco Giner se llevó a cabo en el marco de la Institución Libre de Enseñanza, fundada en Madrid en 1876, en la que tuvo durante cuarenta años, hasta su muerte en 1915, el principal protagonismo, y con la que mantuvo siempre una profunda identificación. La Institución fue, en palabras de Rafael Altamira, «su creación más honda y su medio de influencia más poderoso» (Altamira, 1915: 61), y en su Boletín ofreció, como advirtió Juan López-Morillas, «sus ideas y esperanzas, sus recelos y aversiones», hasta hacer de él «una especie de diario íntimo» (López-Morillas, 1988: 30). La actividad de Giner —y la de la Institución - tuvo una finalidad principal: modernizar el panorama educativo, científico y cultural de España, o, dicho en otros términos, europeizarlo. Se trataba de incorporar los fundamentos de la cultura europea —su «sustancia», como precisó López-Morillas, no sus «accidentes» o sus «formas aisladas» (López-Morillas, 1980: 29-30)_, y de aplicar sus posibilidades a la modernización de la situación española. Y todo ello sin renunciar a lo español, a los valores de variada índole del propio horizonte cultural. Había en la Institución Libre de Enseñanza, como señaló Azorín, «una nota de universalidad y otra nota de españolismo», y ambas notas se hallaban igualmente presentes en el pensamiento de su principal impulsor: "Giner y su europeísmo, aliado al amor por el paisaje de Castilla. Giner, europeo y apasionado del Guadarrama» (Azorín, 1967: 124, 127).

Ese empeño de modernización fue uno de los rasgos característicos de los planteamientos de Francisco Giner y de la Institución Libre de Enseñanza. A ello se refirió el propio Giner, entonces Rector, en su discurso inaugural del curso académico 1880-81. La Institución se había orientado, dijo, «en los progresos obtenidos por otras naciones», y había enviado a sus profesores "para estudiarlos de cerca», procurando después aplicar esos progresos a la situación española, adaptándolos a su «genio y circunstancias» y completándolos con los resultados de la propia experiencia. Esa era precisamente la clave para «iniciar algún nuevo camino», acorde con los planteamientos actualizados de la cultura pedagógica de entonces (Giner de los Ríos, 2004a: 267). Y con ese afán de modernización, de introducir en España, procurando adaptarlos y completarlos, los progresos obtenidos por otras naciones, se relaciona la visión del paisaje ofrecida inicialmente por Francisco Giner y prolongada después, siguiendo sus pasos, por la Institución Libre de Enseñanza. 
Entre los progresos foráneos de índole intelectual y educativa que interesaron a Giner y a la Institución, se contó la perspectiva de la geografía moderna, inicialmente promovida, desde principios del siglo XIX, por Alexander von Humboldt y Karl Ritter, y, dentro de ella, el nuevo modo de entender el paisaje principalmente debido al primero de ellos. El paisajismo geográfico moderno, conformado primeramente por Humboldt y continuado después en la geografía decimonónica posterior, fue así unos de esos progresos obtenidos por otras naciones que Francisco Giner y la Institución Libre de Enseñanza incorporaron y aplicaron a sus consideraciones sobre el paisaje español. Conocieron y aplicaron, por tanto, las actitudes y las intenciones que caracterizaron los planteamientos paisajísticos de la geografía moderna, su manera de acercarse a lo que el paisaje es y a lo que significa, y su interés en aunar en el empeño puntos de vista distintos pero complementarios, en términos físicos y también intelectuales, apoyándose siempre en lo que Vincent Berdoulay y Hélène Saule-Sorbé denominaron «la movilidad de la mirada» (Berdoulay \& Saule-Sorbé, 1998). La visión del paisaje español conformada por Giner y secundada por la Institución recoge todos esos ingredientes, y se inscribe de forma plena en las coordenadas de la modernidad paisajística europea de su tiempo. Se introdujo así en España el componente geográfico (y paisajístico) de la cultura europea moderna, es decir, la cultura geográfica y, dentro de ella, la cultura geográfica del paisaje, vinculadas a la modernidad cultural europea.

Ese paisajismo de cuño geográfico, conformado en el marco del horizonte romántico, compartía con otras modalidades coetáneas de similar finalidad — desde las predominantemente artísticas, al modo de Rousseau, Saint-Pierre, Friedrich o Turner, hasta las más vinculadas a intenciones científicas y naturalistas, como las de Saussure o Ramond- las claves de la nueva manera de entender el paisaje, de verlo y de valorarlo, pero aportaba también algunas peculiaridades. Una de ellas, sin duda la más interesante y fecunda, fue la búsqueda de una relación equilibrada entre las miradas explicativa y comprensiva —entre la ciencia y el arte, si se prefiere, o entre la razón y el sentimiento- a la hora de entender el paisaje. El paisajismo geográfico alentado por Humboldt tuvo en cuenta al tiempo el modo de ver y valorar el paisaje de los naturalistas, a la manera de Saussure, con su énfasis explicativo, científico, y el de los artistas, más dados a lo comprensivo y estético, como había mostrado ejemplarmente Rousseau. Unos y otros habían sido ya conscientes, desde luego, de la necesidad de compaginar la explicación y la comprensión, los puntos de vista de la ciencia y el arte, a la hora de entender el paisaje, pero en ambos 
casos la importancia concedida a esos dos componentes se inclinaba decididamente hacia uno de ellos, el explicativo o el comprensivo, dejando al otro en un lugar secundario. La singularidad de la propuesta paisajística de Humboldt, apoyada en su amplitud de miras y en su sólida formación naturalista y humanista al tiempo, fue conformar una visión en la que la explicación y la comprensión igualaban su importancia.

El propio Humboldt señaló con claridad su intención de aunar equilibradamente ambas miradas en sus Cuadros de la Naturaleza, el libro que abrió, en 1808, el camino de ese nuevo paisajismo geográfico. Quería hablar a la razón y al sentimiento de sus lectores, hermanar la historia natural y la estética, «cautivar la imaginación y enriquecer la vida con ideas y conocimientos nuevos» (Humboldt, 1990, I: 5). El editor de la traducción francesa de ese libro llamó la atención en una nota sobre la original convergencia en sus páginas de la explicación científica y la comprensión artística: era, decía, una obra maestra, capaz de ofrecer la suma de la perspectiva de Bernardin de Saint-Pierre y la exactitud de la ciencia. Humboldt era un científico destacado y, además, un buen escritor, dotado de sensibilidad literaria y de una notable capacidad expresiva, y ambas cualidades hicieron posible su modo de entender el paisaje y de representarlo, aunando la mirada explicativa y la comprensiva. Y este rasgo característico del paisajismo geográfico de Humboldt, que se prolongó después en los exponentes más destacados del paisajismo geográfico, ayudó a ampliar su influencia posterior: no solo se dejó sentir en el mundo de la ciencia, en el mundo más interesado por describir y explicar el paisaje, sino también en el ámbito del arte, entre los autores más preocupados por sentirlo y comprenderlo. El paisajismo de Humboldt tuvo así una influencia directa y notable en la cultura europea decimonónica, en sus manifestaciones científicas y en sus expresiones artísticas, pictóricas y literarias.

En ese panorama general de influencia se enmarca la que tuvo la perspectiva paisajística de Humboldt en Francisco Giner y, en buena medida a través de él, en la Institución Libre de Enseñanza. Bernardo Giner, hermano del anterior, tradujo entre 1874 y 1878, años cercanos a la fundación de la Institución, tres obras paisajísticamente fundamentales de Humboldt: Cuadros de la Naturaleza, Sitios de las cordilleras y monumentos de los pueblos indígenas de América, y Cosmos: ensayo de una descripción física del mundo. Y a la influencia directa de Humboldt se añadió la del geógrafo francés Élisée Reclus, que prolongó la perspectiva paisajística del primero y la aplicó, en el tomo primero de su Nouvelle Géographie Universelle, publicado en 1876, el año del nacimiento de la Institución, al 
paisaje de España. La influencia de la obra de Reclus, con sus imágenes del paisaje español y, en especial, del paisaje castellano, contribuyó a reforzar la presencia del paisajismo geográfico moderno en el círculo gineriano e institucionista.

Esa fue la perspectiva paisajística de signo geográfico que incorporaron Giner y la Institución Libre de Enseñanza. Con ella pudieron superar los límites estéticos de las anteriores imágenes románticas del paisaje de España y proponer un modo de entenderlo más amplio y complejo, simultáneamente interesado en su explicación y en su comprensión. Y esta nueva visión del paisaje español promovida por Giner y la Institución estuvo estrechamente relacionada con su ideario y sus aspiraciones, con su forma de entender la situación del país, de valorar su pasado y su presente, y de imaginar las soluciones que consideraban más adecuadas para sus problemas. Las cualidades que Francisco Giner y los institucionistas descubren en el paisaje, los valores y los significados que le atribuyen, son inseparables de su pensamiento y de sus creencias. La imagen del paisaje forma parte de su «imaginario», del conjunto de representaciones que expresan simbólicamente la concepción del mundo que les rodea y las posibilidades de mejorarlo. De ahí que hubiese una clara conexión entre su visión del paisaje de España y su orientación patriótica, con su interés por definir las claves de la identidad nacional, los rasgos distintivos del carácter y de la historia del pueblo español. Porque, como señaló Inman Fox, Giner y la Institución participaron activamente en «la construcción de una identidad nacional española» (Fox, 1997: 15), y su modo de entender el paisaje estuvo estrechamente relacionado con los diagnósticos y las aspiraciones de ese horizonte. Para Giner y para la Institución, acercarse al paisaje era un modo de acercarse al pueblo español, a su carácter y a su historia. Esa conexión no hacía sino traducir la convicción del paisajismo geográfico moderno sobre la existencia de correspondencias entre los paisajes y los pueblos que los habitan. Por eso desempeñó el paisaje un papel destacado en el horizonte intelectual y político del círculo gineriano e institucionista: su modo de verlo y valorarlo comprendía una clara intención de afirmación nacional, de búsqueda de las notas distintivas, propias, de la identidad nacional española.

\section{Los valores del paisaje}

Francisco Giner resumió su perspectiva paisajística en el artículo que, con el título de «Paisaje», publicó en 1886 en La Ilustración Artística, en el que puede distinguirse con bastante claridad la presencia del horizonte 
geográfico moderno. La cercanía de Giner a ese horizonte pudo verse favorecida, en primer lugar, por su conocimiento de la obra de Humboldt, al que cita en ese artículo, y, en segundo lugar, por la común ascendencia, idealista y alemana, del pensamiento geográfico y del gineriano, que hizo que ambos mostrasen coincidencias significativas a la hora de entender y valorar el mundo exterior, la naturaleza y el paisaje, y que las propuestas paisajísticas del primero pudiesen integrarse fácilmente en los planteamientos del segundo. La idea de paisaje manejada por Giner es un ejemplo expresivo de esa cercanía. Al igual que la geografía moderna, Francisco Giner concibe el paisaje como la expresión visible de un orden natural —un paisaje natural - en el que queda comprendido el hombre. Lo entiende por tanto como una entidad natural, de la que forman parte diversos elementos, «tantos como fuerzas, seres y productos despliega la naturaleza ante nuestros ojos», desde «la tierra y el agua en sus formas» $\mathrm{y}$ «el mundo vegetal con sus tipos, figuras y colores», hasta «el hombre con sus obras» (Giner de los Ríos, 2004d: 792). Y entre estos elementos, el relieve juega, como lo jugaba en el paisajismo geográfico coetáneo, un papel de especial relevancia en la caracterización del paisaje, incluyendo sus cualidades estéticas. Hay una estrecha relación, dice Giner, entre el suelo y el paisaje, entre la geología y la estética, y esa relación depende de la naturaleza litológica, de la disposición tectónica y del comportamiento frente a la erosión química superficial de los materiales. Sus comentarios sobre este asunto son una muestra sumamente elocuente de la vertiente geográfica de su perspectiva paisajística, como puede comprobarse en párrafos como el que sigue:

Esta relación del suelo con el paisaje, de la geología con la estética, que ya ilustraron en sus tiempos un Cuvier y un Humboldt, presenta problemas de interés extraordinario. Respecto de los materiales de los terrenos arcaicos, v. g., pueden observarse delicadas diferencias entre las formas graníticas y las gnéisicas, diferencias tan visibles casi como las que separan ambas clases de formas de las que ofrecen los conglomerados de Montserrat, o las calizas carboníferas en las cumbres de los Picos de Europa, o los depósitos lacustres de los llanos de la Tierra de Campos. Sin embargo, la distinta posición orográfica de unos mismos materiales, esto es, el plegamiento de las capas, influye considerablemente en el paisaje. Igualmente, una acción química superficial puede dar a las rocas un aspecto muy diverso del que usualmente revisten. Recuerdo el magnífico tono frío amoratado de los acantilados del circo de las Dos Hermanas, en el macizo de Peñalara, debido a la hidratación del óxido de hierro contenido en las micas de sus gneises; mientras que en el puerto del Reventón, 
en el vallecito de la Berzosa (debajo de la Maliciosa y de las Cabezas de Hierro), y en tantas y tantas otras partes, ese mismo gneis, por cuyas lajas corre una fina capa de agua, ofrece los rojos más cálidos, ricos y transparentes, merced a otro grado de hidratación de esos mismos hierros (Giner de los Ríos, 2004d: 796-797).

Los elementos del paisaje - el relieve, la vegetación, el agua, el cielo, la atmósfera, los animales, el hombre y sus obras - forman una unidad natural, resultado de un conjunto de relaciones naturales, de la que el hombre es un componente natural más, que, al igual que los restantes, pertenece al orden de la naturaleza. El hombre y sus obras forman parte del paisaje, advierte Giner, «a condición de avenirse a no representar más que uno de tantos accidentes, de subordinarse a la naturaleza - por decirlo asídeshabitada». De esa forma, acatando el orden natural y las relaciones que comprende, es como pasan a formar parte del paisaje las obras debidas al hombre - casas, caminos, tierras cultivadas - y «el hombre mismo, cuya presencia anima con una nueva nota de interés el cuadro entero de la naturaleza». El paisaje expresa así el orden natural, el resultado unitario, sintético, de las relaciones naturales entre todos sus componentes, físicos y humanos. El paisaje es la expresión visible de una unidad geográfica natural. «En su más rigurosa acepción —añade Giner-, el paisaje es la perspectiva de una comarca natural; como la pintura de paisaje es la representación de esa perspectiva» (Giner de los Ríos, 2004d: 792-793).

Esta visión naturalista del paisaje, similar a la que suscribió la geografía a lo largo del siglo XIX, entraña algunos aspectos sin duda importantes. Supone que el hombre es parte de la naturaleza, que mantiene con ella una relación continua que queda plasmada en el paisaje. Hay, según Giner, una clara «relación entre la constitución geológica, el relieve del suelo, el clima, el medio natural, en suma, y el hombre», y esa relación deja su huella «en la constitución de nuestro cuerpo como en la de nuestra misma fantasía, de donde trasciende a nuestros gustos, hábitos, artes, a la obra y modo entero de la vida» (Giner de los Ríos, 2004d: 797). El paisaje expresa la conexión entre el hombre y su ambiente natural, y entender el paisaje es, en consecuencia, entender los rasgos característicos que ambos comparten. Podemos descubrir en el paisaje las cualidades principales de su caracterización natural, y tales cualidades serán también atribuibles a los hombres que allí habitan. Hay hondas correspondencias entre la naturaleza y el modo de ser, de pensar y de sentir de los hombres relacionados con ella, y de todo ello da cumplida cuenta el paisaje. El acercamiento al 
paisaje es un modo de acercarse al conocimiento del orden natural del mundo y del lugar que el hombre ocupa en él.

El paisaje se entiende además como una realidad dotada de sentido, con valores, cualidades y significados, que hay que tener en cuenta para captarlo cabalmente. Por eso el acercamiento al paisaje requiere, como advirtió Humboldt, aunar la explicación y la comprensión, simultanear el conocimiento apoyado en la razón y el pensamiento con el que se apoya en el sentimiento y la imaginación. Son dos vías de conocimiento distintas y complementarias, y ambas son necesarias para llegar a entender la verdadera entidad del paisaje, a explicar sus formas y a comprender su sentido. De ahí que la visión de Giner no solo atienda a la descripción e interpretación de los rasgos fisonómicos del paisaje, sino que se adentre en la comprensión de su sentido, procurando valorar sus significados subyacentes, su dimensión cualitativa. Y todo ello contribuye a agrandar el interés del paisaje. Entenderlo es también abrirse a un mundo de significados, de valores y cualidades, cuya comprensión puede ayudar sustancialmente a mejorar la educación del hombre. El contacto con el paisaje se convierte así en un medio educativo de primer orden: permite educar no solo la inteligencia, sino además, al tiempo, la sensibilidad y la imaginación; ayuda a cultivar simultáneamente, sin disociaciones inconvenientes, las capacidades intelectuales, éticas y estéticas de la persona. El «contacto purificador de la Naturaleza» favorece siempre, en palabras de Giner, «la expansión de la fantasía, el ennoblecimiento de las emociones, la dilatación del horizonte intelectual, la dignidad de nuestros gustos y el amor a las cosas morales» (Giner de los Ríos, 2004d: 799).

El contacto directo con el paisaje puede ser una experiencia gozosa. A través de él, el hombre puede compenetrarse con el orden natural, establecer conexiones profundas — «analogías misteriosas y morales armonías», en palabras de Humboldt (1874-1875, II: 4)— con lo que le rodea, y captar la entidad y el alcance de las correspondencias entre lo exterior y lo interior que la visión moderna del paisaje considera fundamentales. Humboldt habló también de estas correspondencias, de los «lazos secretos e indisolubles» que unen lo de fuera y lo de dentro, de cómo «el mundo físico se refleja en lo más íntimo de nuestro ser con toda su verdad viviente», para concluir que es justamente en esa relación, en esa «armonía», en la que "descansan los más nobles goces que la naturaleza nos ofrece» (Humboldt, 1876: 210). De esos nobles goces, asociados a las correspondencias entre lo exterior y lo interior que se dejan sentir en la relación directa con el paisaje, habla Giner de forma elocuente, evocando, 
con aliento pictórico, la impresión que había sentido durante un anochecer en la Sierra de Guadarrama:

Jamás podré olvidar una puesta de sol, que, allá en el último otoño, vi con mis compañeros y alumnos de la Institución Libre desde estos cerros de las Guarramillas. Castilla la Nueva nos aparecía de color de rosa; el sol, de púrpura, detrás de Siete Picos, cuya masa, fundida por igual con la de los cerros de Riofrío en el más puro tono violeta, bajo una delicada veladura blanquecina, dejaba en sombra el valle de Segovia, enteramente plano, oscuro, amoratado, como si todavía lo bañase el lago que lo cubriera en época lejana. No recuerdo haber sentido nunca una impresión de recogimiento más profunda, más grande, más solemne, más verdaderamente religiosa (Giner de los Ríos, 2004d: 799).

En la existencia de conexiones y correspondencias entre el paisaje y quienes lo habitan, reconocidas expresamente por el paisajismo geográfico y por Giner, se apoya la importancia adquirida por el conocimiento del primero a la hora de descubrir los rasgos característicos de los segundos. La solidaridad entre el hombre y el paisaje se manifiesta a la vez de forma individual y colectiva. Conocer el paisaje es un medio para conocer a los hombres relacionados con él. Francisco Giner habla, por ejemplo, del «grave, seco, y un tanto bravío habitante de la no menos grave, seca y bravía tierra de Campos» (Giner de los Ríos, 2004e: 786). Y junto a su expresión individual, esos nexos muestran también una dimensión colectiva o social. Las características propias de los grupos sociales - de los pueblos- están asociadas a las de los paisajes en los que viven y se desenvuelven, y por eso estos adquieren significado histórico e identitario. El conocimiento del paisaje ayuda así a identificar las claves del propio pasado histórico y de la identidad común conformada a lo largo de ese pasado. En el horizonte historiográfico gineriano e institucionista, deudor de las ideas de Herder y Krause, interesado siempre en descubrir, bajo la superficie de la historia externa u oficial, la historia interna o intrahistoria del pueblo español, la que se identifica con su carácter o psicología, con su cultura colectiva, la consideración del paisaje adquiere una notable importancia. Al igual que ocurre con el arte o la literatura, el paisaje nos acerca a la caracterización intrahistórica del pueblo español, a los rasgos más genuinos de su tradición cultural y de su identidad colectiva. En este marco interpretativo se sitúan los elocuentes comentarios de Rafael Altamira sobre el sentido y el alcance del paisajismo de Giner, de quien dice que supo sentir el paisaje castellano «con una emoción tan honda y una tan grande claridad de concepto, que le llevaron hasta la más profunda 
raíz de patriotismo que emana de la tierra en que formó un pueblo su alma y su historia» (Altamira, 1921: 220).

La aportación paisajística de Francisco Giner fue valiosa y fecunda. Su modo de entender el paisaje, de verlo y valorarlo, que incorporó la perspectiva del paisajismo geográfico moderno, fue tan innovador como feraz. Abrió el camino de la cultura moderna del paisaje en España, e influyó de manera muy notable no solo en todo el paisajismo promovido, hasta su desaparición en 1936, por la Institución Libre de Enseñanza, que secundó fielmente sus ideas y sugerencias, sino también, al tiempo, en otros círculos intelectuales, artísticos y deportivos interesados por el paisaje. Es lo que sucedió, por ejemplo, con los escritores y pintores de la denominada generación del 98 (Martínez de Pisón, 2012; Ortega Cantero, 2007b), o con los enfoques de la política turística dirigida por el marqués de la VegaInclán (Ortega Cantero, 2014b), o, en fin, con el planteamiento cultural y excursionista de las primeras sociedades de alpinismo madrileñas (Ortega Cantero, 2014a). Giner contribuyó así notablemente a que arraigaran y se extendiesen en España las claves de la visión moderna del paisaje. Su modo de entenderlo, de pensarlo y de sentirlo, quedó ejemplarmente plasmado en su artículo de 1886 y en las diversas evocaciones de paisajes españoles que aparecieron en algunos de sus restantes escritos.

\section{Imágenes del paisaje español}

Francisco Giner ofreció diversas imágenes del paisaje español, generalmente asociadas a sus relatos de excursiones. En el dedicado a «Santiago de Peñalba», por ejemplo, de 1884, habló del paisaje «de primer orden» en el que se inscribe la iglesia, característico del Bierzo: «valles risueños y estrechísimos, montañas de rápida pendiente, copioso arbolado, y una abundancia de cascadas y arroyos sin igual en otras comarcas semejantes de Asturias, Santander y Galicia, y que mantiene en la vegetación indescriptible frescura» (Giner de los Ríos, 2004e: 788). Y entre sus impresiones paisajísticas más acabadas, se cuentan las incluidas en sus escritos sobre «Mérida y Badajoz», de 1879, y sobre «El Real Sitio del Pardo», de 1883 , y, por supuesto, en el titulado «Paisaje», ya citado, de $1886^{2}$. En el primero, habla Giner de las ruinas de los acueductos romanos de

2. Tanto el escrito sobre «Santiago de Pañalba», como los dedicados a «Mérida y Badajoz» y a «El Real Sitio del Pardo», se recogieron en el tomo vigésimo de las obras completas de Francisco Giner, aparecido en 1936, con el título de Arqueología artística de la Península y una nota preliminar de Juan Uña y Sarthou. Los tres, junto al titulado «Paisaje», que no se recogió en esas obras completas, han sido incluidos después en el apartado 
Mérida, grandiosas y pintorescas a la vez, que se funden con otros elementos naturales y humanos - la llanura, el río, la vegetación, la luz, el cielo, las cigüeñas, el ferrocarril- para formar conjuntamente un paisaje de "gravedad serena y melancólica», capaz de producir una honda impresión. Nada mejor para comprobar esas cualidades que contemplarlo, como hace Giner, desde el puente romano del arroyo Albarregas:

Desde este punto de vista pintoresco, nada excede a la impresión de los gigantescos pilares que se contemplan desde el puente de Albarregas (Alba regia), romano también, pero completamente modernizado: aquellas masas imponentes, apenas enlazadas por las mal unidas dovelas de alguno que otro tramo; aquel tono tan grave, tan riguroso y caliente; aquella llanura suavemente ondulada, como la campiña de Roma; aquel verdor que brota en los cimientos y pugna por elevarse hasta las más altas piedras, sobre las cuales se apiñan las cigüeñas en inmenso número; aquel ferrocarril tendido por bajo de los arcos, y aquel río, y aquella luz, y aquel cielo, forman uno de esos paisajes que excitan un mundo de ideas, de sentimientos, de representaciones en la fantasía (Giner de los Ríos, 2004c: 749-750).

El Pardo fue uno de los lugares más visitados por Giner y sus compañeros institucionistas. Fueron proverbiales sus paseos dominicales, desde la sede de la Institución Libre de Enseñanza, en el Paseo del Obelisco (el actual Paseo del General Martínez Campos) desde mediados de los años ochenta, hasta la Puerta de Hierro y El Pardo. Acompañaban a Giner sus amigos y colaboradores de la Institución, y cuenta Constancio Bernaldo de Quirós que algunos de los que residían fuera procuraban aprovechar sus estancias en Madrid para participar en esos paseos y tener así ocasión de hablar con él tranquilamente (Bernaldo de Quirós, 1964: 175-179). «De recién llegado a Madrid —decía Juan Ramón Jiménez-, todos los domingos iba yo al Pardo y regresaba a pie, acompañando a D. Francisco Giner» (en Reyes, 1956: 393). Al norte y al lado de la ciudad de Madrid, unido a ella por una carretera pequeña y agradable — con «las más hermosas perspectivas en todo su trayecto», en palabras del propio Giner (2004b: 761)—, El Pardo ofrecía a los institucionistas no solo el atractivo de su paisaje natural, con el valioso encinar que lo caracterizaba, y de su palacio renacentista, sino también el interés añadido de constituir un sitio privilegiado para contemplar el panorama de la Sierra de Guadarrama. Acercarse al Pardo era

«Sobre arte, literatura y paisaje» de sus Obras selectas (Giner de los Ríos, 2004b; 2004c; 2004d; 2004e). 
también, al tiempo, acercarse a una visión amplia, panorámica, de la Sierra de Guadarrama. Giner trazó una imagen muy expresiva de las cualidades paisajísticas del Real Sitio del Pardo:

Este hermosísimo parque, último resto casi, con la Viñuela, la Escorzonera de Remisa, el monte de Boadilla y algún otro manchón insignificante, de la espléndida selva que un tiempo rodeaba a Madrid y que el atraso, la preocupación y la ignorancia han ido talando y reduciendo hasta dejarla trasformada en pobrísima tierra de pan llevar, ofrece todavía, gracias a haberse librado de las imprudencias de la desamortización, un admirable paisaje, donde el sombrío verdor de las encinas, la esmeralda de los pinos, la plateada seda de las retamas, las zarzas, jaras, rosales, espinos, sauces, fresnos, chopos y álamos blancos, cuyo pie alfombran con inagotable profusión el tomillo, el cantueso, el romero, la mejorana y otras olorosas labiadas, que huellan sin cesar gamos y conejos, forman una vista grandiosa, coronada por la vecina sierra con su cresta de nieve en el invierno, sus radiantes celajes en el verano, y en todo tiempo con su imponente masa y graves tintas (Giner de los Ríos, 2004b: 760-761).

Del paisaje de Castilla habló Giner en diferentes ocasiones, y su modo de verlo y valorarlo renovó decisivamente su imagen, distanciándola de la que habían generalizado antes, casi siempre en términos despectivos, los autores románticos. Fue esta una aportación paisajística muy innovadora e influyente. «Giner —advirtió López-Morillas — se adelanta en muchos años a los hombres del 98 en lo que es, también a su modo, un "descubrimiento" suyo: el paisaje castellano, de cuyo aprecio y enaltecimiento tantos testimonios dejó» (López-Morillas, 1988: 103). A propósito de Paredes de Nava, lugar de nacimiento del escultor Berruguete, «en el corazón de lo más castellano de Castilla», habló Giner, por ejemplo, de «esa Castilla la Vieja, tan grave, tan adusta, tan entristecida, tan pálida, cuyo paisaje, como ha dicho un pensador original, está en el cielo, es decir, en las pompas de su azul profundo hasta la negrura y de sus incomparables celajes» (Giner de los Ríos, 1936: 65). En su mencionado artículo de 1886, habló también del paisaje castellano, distinguiendo sus dos modalidades madrileñas - montaña y llano - y trazando una imagen moderna, profundamente innovadora, de la Sierra de Guadarrama, atenta a sus valores naturales, históricos y culturales, que acuñó un modelo posteriormente muy influyente. La revista Peñalara estableció un cierto paralelismo entre Rousseau, que fue para todo el ámbito europeo «el descubridor de la belleza alpina», y Giner, que «fue para nosotros el revelador del Guadarrama» (Peñalara, 1915: 33). Y Eduardo Martínez de Pisón incluyó la visión de la Sierra de 
Guadarrama ofrecida por Giner y por la Institución Libre de Enseñanza entre las que contribuyeron de manera más destacada a conformar el significado cultural, incluso simbólico, de algunas montañas europeas. El valor cultural que adquiere el Guadarrama en el horizonte de Giner y la Institución es comparable, como advierte Martínez de Pisón, al que logran otras montañas europeas "por el estudio y el esfuerzo realizado en ellas por un ilustrado o un científico: así el Mont Blanc con De Saussure, el Monte Perdido con Ramond o el Teide con Humboldt, en el paso del siglo XVIII al XIX» (Martínez de Pisón, 1983: 139).

\section{El paisaje de la Sierra de Guadarrama}

La imagen de la Sierra de Guadarrama ofrecida por Francisco Giner fue la mejor expresión de su modo de entender el paisaje. Y a través de ella, teniendo en cuenta sus fundamentos y sus características, es posible distinguir con bastante claridad las claves de ese modo de verlo y valorarlo. Lo primero que conviene señalar, en este sentido, es que, en consonancia con las directrices del paisajismo geográfico moderno, la visión de la Sierra de Guadarrama de Giner estuvo estrechamente relacionada con las nuevas interpretaciones de ese ámbito montañoso - y de la Meseta a la que, como parte de la Cordillera Central, pertenecía- elaboradas por los geólogos de su tiempo. José Macpherson, que fue profesor de «Trabajos geológicos» de la Institución Libre de Enseñanza y dirigió la «Sociedad para el estudio del Guadarrama» creada en su seno a finales de 1886, desempeñó un papel destacado en todo ello. Mantuvo una gran amistad con Giner - que le consideraba «el primero de nuestros geólogos en su tiempo» (Giner de los Ríos, 1922: 13)—, a quien inició en el conocimiento naturalista de la Sierra de Guadarrama, aportándole, dice Bernaldo de Quirós, la educación que necesitaba para «comprender la grandiosa tectónica de la tierra» (Bernaldo de Quirós, 1922: 186). Las investigaciones de Macpherson renovaron la concepción de la organización geológica de la Península Ibérica, y ofrecieron una nueva interpretación del importante papel desempeñado en ella por la Cordillera Central en general y la Sierra de Guadarrama en particular. A esta última, y en especial al ámbito del macizo de Peñalara y del valle del Lozoya, le atribuyó Macpherson una singular importancia: formaba parte de la Cordillera Central, la «verdadera columna vertebral de la Península Ibérica» (Macpherson, 1883: 358), y era además el sector más antiguo y más resistente de esa alineación montañosa, perteneciente toda ella al núcleo originario del conjunto geológico peninsular. 
El significado atribuido por Macpherson a la Cordillera Central y, dentro de ella, a la Sierra de Guadarrama estaba relacionado con el que se concedió entonces a la Meseta, expuesto con claridad por Salvador Calderón, que fue también profesor de la Institución. La Meseta central o castellana era, según Calderón, el núcleo originario de la Península, la parte medular de lo que el autor denominó, con criterio naturalista, «la primitiva España», que había presidido la historia geológica peninsular: «La Meseta central es el gran factor de toda la constitución geológica, estructura y orografía de la Península, desde la cuenca del Ebro y límites españoles de las estribaciones pirenaicas, hasta las playas meridionales». Adquirió así la Meseta, en la interpretación actualizada de la organización geológica peninsular que se impuso en los últimos decenios del siglo XIX, una importancia natural sobresaliente. Recordando lo que había dicho, a mediados de los años setenta, el autor de la Nouvelle Géographie Universelle, Calderón afirmó que la Meseta castellana «es la Península en pequeño con todos los rasgos fundamentales de su forma, pudiendo decirse geológicamente de ella, como en sentido geográfico y político lo ha dicho Reclus, que es la España por excelencia» (Calderón y Arana, 1885: 136, 169-170).

Ambas valoraciones naturalistas, geológicas, de la Meseta central o castellana y de la Sierra de Guadarrama no fueron ajenas a las valoraciones culturales que Giner y sus compañeros de la Institución Libre de Enseñanza ofrecieron de esos mismos ámbitos. Hay evidentes correspondencias - congruentes con los planteamientos del paisajismo geográfico moderno- entre las nuevas valoraciones naturalistas de la Meseta central o castellana y de la Sierra de Guadarrama, con la importancia que les atribuyen en la historia geológica peninsular, y las también nuevas valoraciones culturales que de esos mismos ámbitos - Castilla y el Guadarramaproponen Giner y sus colaboradores de la Institución, con la importancia que les atribuyen en relación con la historia de España y la conformación, a lo largo de esa historia, de la identidad nacional. La elevada significación cultural que Francisco Giner y la Institución Libre de Enseñanza concedieron a Castilla y, dentro de ella, a la Sierra de Guadarrama estaba directamente conectada con la importante significación natural que las interpretaciones geológicas modernas atribuyeron a esos mismos ámbitos geográficos.

Giner ofreció en su artículo de 1886 una imagen del paisaje de la Sierra de Guadarrama en la que convergían la explicación y la comprensión. La explicación del paisaje era de índole naturalista, y procuraba dar cuenta 
de los componentes y relaciones naturales que lo organizaban, mientras que su comprensión era de signo cultural, e intentaba captar y valorar sus cualidades y significados. En relación con lo primero, con la vertiente explicativa, Giner señala algunos lugares del Guadarrama especialmente impresionantes por su situación y su caracterización natural. Es el caso de «las Cabezas de Hierro, y los espléndidos valles que dominan», o de «la magnífica y vecina Peñalara, con sus ventisqueros, sus lagunas, sus circos, sus acantilados, sus panoramas espléndidos, que abrazan desde el Pisuerga al Manzanares» (Giner de los Ríos, 2004d: 800). Y en sus descripciones panorámicas, de esos panoramas a menudo espléndidos que permiten abarcar las alturas del Guadarrama, se deja sentir el aliento naturalista y geográfico del modo gineriano de ver el paisaje. Procura en ellas prestar atención al tiempo a los elementos principales del paisaje y a las formas de organización natural que resultan de las relaciones entre ellos. Como en el horizonte geográfico moderno, la visión panorámica es en Giner un modo de acercarse a la organización del paisaje, al orden natural que lo fundamenta. Tal es el caso, por ejemplo, de la descripción panorámica que ofrece desde la cumbre de las Guarramillas, después de haber recorrido el camino entre la estación del ferrocarril de Villalba y el puerto de Navacerrada:

Dejamos muy atrás la zona de la vid; estamos en plena región alpestre. Sigamos, y llegaremos a la cumbre, al puerto de Navacerrada, límite de las dos Castillas, cuyo desnivel se advierte al punto, y divisoria entre el Tajo y el Duero; y si tomamos por la ladera hacia el Este, con solo subir unos cien metros, al primer cerro de las Guarramillas, contemplaremos el más grandioso panorama. Tenemos debajo las apretadas masas de los pinares de Valsaín, al fin de cuyos tonos, oscuros y enérgicos, clarean con espléndida luz los llanos de Segovia, que muestra allá en la bruma las torres de sus monumentos; coronándolo todo el imponente macizo de Peñalara, al E. del cual se extiende el suave cordón, que forma el puerto del Paular y defiende el valle del Lozoya; mientras que al Sur, la meseta de Castilla la Nueva, en que Madrid dibuja apenas su silueta cárdena, prolonga las curvas de su modelado hasta perderse en el celaje; y al O., la cadena de la cordillera viene corriendo por cima del Escorial a cerrar del otro lado el puerto con las quebradas alturas de Siete Picos. Desde este núcleo, multitud de ríos se van formando y despeñando en distintas direcciones: por la vertiente meridional, el Guadarrama, el Manzanares, el Guadalix, el Lozoya, el Jarama, que más o menos pronto llevan sus aguas hasta el Tajo; por la vertiente norte, el Eresma, el Valsaín, el Clamores, el arroyo de Moros, que van a acabar en el Duero (Giner de los Ríos, 2004d: 798-799). 
Ofrece Giner también algunos comentarios que no se limitan al ámbito del Guadarrama, sino que se refieren al conjunto del paisaje de la provincia de Madrid, relacionando, con sus similitudes y diferencias, el paisaje montañoso de la Sierra y el de la cuenca sedimentaria. A semejanza de lo que estaban planteando Macpherson y Calderón en términos geológicos, la valoración que Giner propone de la Sierra de Guadarrama se inscribe en la que, con carácter más general, plantea a propósito de Castilla. Montaña y llano se asocian en la perspectiva de Giner, y ambas formas, aunque distintas, comparten características y valores que remiten, en último término, a su común pertenencia al núcleo de la Meseta castellana. El razonamiento desarrollado por Giner para caracterizar y comparar esas dos modalidades del paisaje castellano se apoya en la mirada naturalista. Tiene en cuenta los dos componentes naturales que el enfoque geográfico moderno consideraba fundamentales: el relieve y la vegetación. Considera sus formas, sus fisonomías, usando criterios geológicos y botánicos. Las formas del relieve de la Sierra y del llano dependen de la naturaleza de los materiales geológicos y de su consiguiente comportamiento frente a los agentes erosivos. De ahí procede el primer contraste natural importante entre el paisaje de la montaña, que Giner ejemplifica en el conjunto granítico de la Pedriza de Manzanares, y el paisaje del llano, formado por sedimentos recientes. Frente a las formas abruptas del relieve del Guadarrama, aparecen las formas muy suaves del «valle de Madrid», de los llanos de la cuenca sedimentaria, donde Giner dice encontrar uniformidad, pero no monotonía. A ese contraste geológico se añade el botánico, y Giner advierte la correspondencia que existe, en cada caso, entre el relieve y la vegetación. Las diferencias geológicas entre el paisaje de la Sierra y el paisaje del llano aparecen asociadas a diferencias de vegetación no menos importantes. Presta atención a esas diferentes vegetaciones y, al describirlas y comentar su notable contribución fisonómica, aporta una imagen interesante y significativa de los dos paisajes, en la que, con marcado sentido pictórico también en esta ocasión, se refiere a la valoración de las características y las cualidades estéticas y aun morales que ha descubierto en ellos:

En la montaña, severa hasta la majestad, todo es mate y adusto: los líquenes que tiñen el verdoso granito; el monte bajo, cuyo tono apenas templan, allá en la primavera, el morado cantueso, la amarilla flor de la retama, el rojo de tal cual amapola o de las opulentas peonías; el sombrío verdor de los pinos, que se alzan sobre ellos, ora esbeltos y erguidos, ora corpulentos y nudosos, o muertos con el gris de plata de sus ramas 
desnudas, retorcidas y secas. Abajo, en el amplio valle, la luz es más igual; las sombras menos acentuadas, los tonos más ricos y brillantes; los olmos, los chopos, los sauces, los espinos, las zarzas, agotan casi todos los matices del verde, desde el álamo blanco al negro de la encina; y en medio de las tierras sembradas y de las praderas, con su yerba corta, fina y rala, clarean sobre el suelo anchas ráfagas sonrosadas, de una espléndida carnación luminosa (Giner de los Ríos, 2004d: 795).

La montaña y el llano de Madrid son dos ámbitos naturales diferentes, con distintos rasgos geológicos y botánicos, que ofrecen, por tanto, distintas fisonomías, paisajes diferentes. Pero ese contraste natural, fundado en la consideración naturalista, se va a ver muy atenuado, en el razonamiento de Giner, a través de una mirada más subjetiva y más amplia, de signo cultural, que se adentra en el descubrimiento y en la valoración de sus cualidades y significados de índole intelectual, estética y moral. A la explicación naturalista sucede, sin desconectarse de ella, la comprensión cultural del paisaje. Y con ella culmina el modo gineriano de entender la Sierra de Guadarrama y, en general, el paisaje castellano. En la montaña y en el llano cabe encontrar, según Giner, contrarrestando sus diferencias naturales, rasgos cualitativos comunes que permiten igualarlos en términos de valoración cultural. Tales rasgos proceden de la común pertenencia de los dos ámbitos al paisaje castellano. Y es en este terreno de la valoración cultural donde Giner ofrece las reflexiones más originales sobre el paisaje de la Sierra de Guadarrama. Después de referirse al contraste natural entre la montaña y el llano, habla de esas cualidades y valores que lo suavizan, razona sobre su singularidad y su significado, procura aclarar su sentido, y ofrece así una valoración cultural densa y sugestiva de la Sierra de Guadarrama:

Suaviza, sin embargo, este contraste una nota fundamental de toda la región, que lo mismo abraza al paisaje de la montaña que el del llano. En ambos se revela una fuerza interior tan robusta, una grandeza tan severa, aun en sus sitios más pintorescos y risueños, una nobleza, una dignidad, un señorío, como los que se advierten en el Greco o Velázquez, los dos pintores que mejor representan este carácter y modo de ser poético de la que pudiera llamarse espina dorsal de España (Giner de los Ríos, 2004d: 795).

Esta es la esencia de la imagen cultural del paisaje de la Sierra de Guadarrama ofrecida por Francisco Giner y adoptada luego por la Institución Libre de Enseñanza. Atribuyó a ese paisaje un conjunto de cualidades morales —robusta fuerza interior, severa grandeza, nobleza, dignidad, 
señorío, carácter y modo de ser poético- que se correspondían con las cualidades que consideraba propias, distintivas, del pueblo español. La Sierra de Guadarrama no solo ofrecía la más acabada muestra de las cualidades del paisaje castellano del que formaba parte, sino que, además, esas cualidades se correspondían con bastante fidelidad con las que el horizonte historiográfico de Giner y de la Institución atribuyó a Castilla - la Castilla medieval-, y que, a través del protagonismo histórico castellano, contribuyeron de manera decisiva, según ese mismo horizonte, a conformar la comunidad nacional española. Esas correspondencias entre las cualidades del paisaje y los rasgos característicos de la propia historia y de la identidad nacional forjada en ella fundamentaron el significado de la imagen de la Sierra de Guadarrama ofrecida por Giner - y, en general, por el círculo institucionista- Su interpretación hizo de la Sierra de Guadarrama un lugar especialmente importante y significativo. Las cualidades que Giner descubrió allí, y el hondo significado que su visión concedió a tales cualidades, hacen del paisaje de la Sierra de Guadarrama un lugar cargado de valor cultural y simbólico. Ese paisaje entraña así un conjunto de valores - éticos, estéticos e intelectuales- que se corresponden con los que fundamentan el ideario gineriano e institucionista, y pasa a desempeñar por ello un importante papel simbólico en relación con las claves del horizonte liberal y reformista vinculado a ese ideario.

Teniendo en cuenta la valoración natural de la Sierra de Guadarrama promovida por los geólogos de la época, Giner añadió su propia valoración cultural de ese mismo paisaje. Explicación naturalista y comprensión cultural quedaron así conectadas en su visión de ese paisaje. Y existen, como dijimos antes, marcadas analogías entre esas dos valoraciones: la importancia natural de la Meseta central, su decisivo papel en la historia geológica de España, se corresponde con la importancia cultural que adquiere Castilla en el horizonte gineriano, con el singular significado que se atribuye a su participación en la historia de España. Lo mismo sucede, dentro de la Meseta y de Castilla, con la Sierra de Guadarrama: si en términos naturalistas, geológicos, Macpherson había dicho, en 1883, que la Sierra de Guadarrama formaba parte de la «columna vertebral de la Península Ibérica», poco después, en 1886, Giner la consideraba, desde el punto de vista cultural y moral, la «espina dorsal de España». La Sierra de Guadarrama se ve como una atalaya natural y, al tiempo, como una atalaya cultural. Acercarse a ella, andar por sus caminos y ascender a sus cumbres, era para Giner y los institucionistas una forma de elevarse a una mejor comprensión cultural, histórica y nacional, de Castilla y de 
España. «Giner y sus amigos —escribió Joaquín Xirau- emprendieron el camino de la Sierra. Fue uno de sus primeros y grandes descubrimientos. Desde lo alto de la Sierra dominaban Castilla y desde Castilla España entera» (Xirau, 1969: 42). El paisaje de la Sierra de Guadarrama se convirtió así, dentro del horizonte reformista de Giner y de la Institución, en un verdadero símbolo de los valores vertebradores de la propia historia y de la identidad nacional. Y la imagen que ofrecieron de ella fue la más acabada muestra de su modo de entender el paisaje, directamente relacionado con la perspectiva geográfica, que inició en España la trayectoria del paisajismo moderno.

\section{Bibliografía citada}

Altamira, Rafael, «Giner de los Ríos», BILE [Boletín de la Institución Libre de Enseñanza], 39, 659-660 (1915), pp. 59-62.

— «El paisaje y los Parques Nacionales de España», BILE, 45, 736 (1921), pp. 220-222.

Azorín, «Cossío», en Crítica de años cercanos, Madrid, Taurus, 1967, pp. 124-127.

BERDOULAY, Vincent \& Hélène SAULE-SORBÉ, «La mobilité du regard et son instrumentalisation. Franz Schrader à la croisée de l'art et de la science», Finisterra, 33, 65 (1998), pp. 39-50.

BERNALDO DE Quirós, Constancio, «La memoria de Don Francisco Giner», BILE, 46, 740 (1922), pp. 185-187.

- «Recuerdos y enseñanzas de don Francisco Giner», en AA. VV., Estudios jurídicos en homenaje al Profesor Luis Jiménez de Asúa, Buenos Aires, AbeledoPerrot, 1964, pp. 167-203.

BESSE, Jean-Marc, «La fisionomía del paisaje: de Alexander von Humboldt a Paul Vidal de la Blache», en La sombra de las cosas. Sobre paisaje y geografia, ed. Federico López Silvestre, trad. Marga Neira, Madrid, Biblioteca Nueva, 2010, pp. 115-137.

CALDERÓN y ARANA, Salvador, «Ensayo orogénico sobre la Meseta central de España», Anales de la Sociedad Española de Historia Natural, 14 (1885), pp. 131-172.

FOX, Inman, La invención de España: nacionalismo liberal e identidad nacional, Madrid, Cátedra, 1997.

GINER DE LOS RÍOS, Francisco, «Instrucción y educación», en Estudios sobre educación (Obras completas, VII), pról. Ricardo Rubio, Madrid, s. e., 1922, pp. 3-18.

- «La escultura castellana», en Arqueología artística de la Península (Obras completas, XX), pról. Juan Uña, Madrid, s. e., 1936, pp. 63-71. 
— «El espíritu de la educación en la Institución Libre de Enseñanza. A. Discurso inaugural del curso 1880-1881», en Obras selectas, ed. Isabel Pérez-Villanueva Tovar, Madrid, Espasa Calpe, 2004a, pp. 257-274.

— «El Real Sitio del Pardo», en Obras selectas, cit. supra, 2004b, pp. 760-764.

- «Mérida y Badajoz», en Obras selectas, cit. supra, 2004c, pp. 747-759.

— «Paisaje», en Obras selectas, cit. supra, 2004d, pp. 792-801.

— «Santiago de Peñalba», en Obras selectas, cit. supra, 2004e, pp. 786-791.

Humboldt, Alejandro de, Cosmos: ensayo de una descripción física del mundo, 4 vols., trads. Bernardo Giner \& José de Fuentes, Madrid, Imprenta de Gaspar y Roig, 1874-1875.

- Cuadros de la Naturaleza, trad. Bernardo Giner, Madrid, Imprenta y Librería de Gaspar, 1876.

- Tableaux de la Nature, 2 vols., trad. M. Ch. Galuski, intr. Charles Minguet \& Jean-Paul Duviols, Nanterre, Éditions Européennes Erasme, 1990.

LÓPEZ-MORILLAS, Juan, El krausismo español: perfil de una aventura intelectual, México D. F., FCE, 1980, 2. ${ }^{a}$ ed.

- Racionalismo pragmático: el pensamiento de Francisco Giner de los Ríos, Madrid, Alianza Editorial, 1988.

MACPHERSON, José, «Sucesión estratigráfica de los terrenos arcaicos de España», Anales de la Sociedad Española de Historia Natural, 12 (1883), pp. 341-378.

MARTíNEZ DE PISÓN, Eduardo, «El espacio natural de Madrid», Revista de Occidente, 27-28 (1983), pp. 137-150.

- Imagen del paisaje: la Generación del 98 y Ortega y Gasset, pról. Helio Carpintero, Madrid, Fórcola Ediciones, 2012.

Ortega Cantero, Nicolás, Paisaje y excursiones (Francisco Giner, la Institución Libre de Enseñanza y la Sierra de Guadarrama), Madrid, Caja Madrid / Editorial Raíces, 2001.

— «La valoración patrimonial y simbólica del paisaje de Castilla (1875-1936)», Ería, 73-74 (2007a), pp. 137-159.

- «Lectura geográfica del paisajismo literario de la generación del 98», en Valerià Paül i Carril \& Joan Tort i Donada (eds.), Territorios, paisajes y lugares (Trabajos recientes de pensamiento geográfico), Cabrera de Mar, Galerada y Asociación de Geógrafos Españoles, 2007b, pp. 281-297.

- «Los valores del paisaje: la Sierra de Guadarrama en el horizonte de Francisco Giner y la Institución Libre de Enseñanza», en José García-Velasco \& Antonio Morales Moya (eds.), La Institución Libre de Enseñanza y Francisco Giner de los Ríos: nuevas perspectivas. 2: La Institución Libre de Enseñanza y la cultura española, Madrid, Fundación Francisco Giner de los Ríos / Acción Cultural Española, 2012, pp. 673-711.

- «Montañismo y valoración del paisaje: la Real Sociedad Española de Alpinismo Peñalara (1913-1936)», Ería, 95 (2014a), pp. 253-279. 
- «Paisaje, patrimonio e identidad en la conformación de la primera política turística española», Ería, 93 (2014b), pp. 27-42.

Peñalara, «Don Francisco Giner de los Ríos», Peñalara, 2, 15 (1915), pp. 33-34.

REYES, Alfonso, «Un recuerdo de Año Nuevo», en Obras completas, IV: Simpatías y diferencias. Los dos caminos. Reloj de sol. Páginas adicionales, México D. F., FCE, 1956, pp. 393-397.

Xirau, Joaquín, Manuel B. Cossío y la educación en España, Barcelona, Ariel, 1969, 2. ${ }^{\mathrm{a}} \mathrm{ed}$.

Fecha de recepción: 15-6-2015

Fecha de aceptación: 1-12-2015 


\title{
«TAN PRÁCTICO ES PENSAR COMO CAVAR LA TIERRA»: FILOSOFÍA, EDUCACIÓN Y PAISAJE EN GINER DE LOS RÍOS
}

\author{
JUAN NAVARRo DE SAN PíO \\ Doctor en Filosofía
}

\section{Resumen}

Giner de los Ríos transformó el krausismo en una filosofía práctica. De nada sirve la filosofía si no es capaz de suscitar un pensamiento autónomo que inspire a su vez una acción. Y esa renovación filosófica se llevó a cabo por medio de la educación, arte de vivir que permite armonizar la teoría y la práctica, la inteligencia y la voluntad, la naturaleza y el espíritu. Aprendemos a filosofar cuando prescindimos de las ideas ajenas y extraemos el pensamiento del contacto directo con el mundo circundante. De igual modo, captamos el sentido de lo bello cuando nuestra sensibilidad dialoga con la naturaleza sin el reflejo del espejo artístico. El excursionismo y la pedagogía del paisaje confieren sentido estético y ético a la filosofía gineriana, cuya herencia intelectual será más reconocible en Ortega que en la generación finisecular.

Palabras clave: Giner de los Ríos; filosofía; educación; paisaje; Ortega y Gasset; Unamuno.

\begin{abstract}
Giner transformed Krausism into a practical philosophy. Philosophy is useless if it is not able to create an autonomous thinking that in turn inspires action. And this philosophical renewal was carried out by means of education, art of living that allows to harmonize theory and practice, intelligence and will, nature and spirit. We learn to philosophize when we ignore other people's ideas and thinking draws direct contact with the surrounding world. Similarly, we grasp the sense of beauty when our sensibility dialogues with nature without the reflection of the artistic mirror. Hiking and pedagogy landscape confer an aesthetic and ethical sense to Giner's philosophy, whose intellectual legacy will be more recognizable in Ortega than in the finisecular generation.
\end{abstract}

Keywords: Giner de los Ríos; philosophy; education; landscape; Ortega y Gasset; Unamuno.

Anales, 27 (2015), pp. 45-57

DOI: 10.14198/ALEUA.2015.27.03 


\section{Aprender a filosofar}

El pensamiento de Giner de los Ríos nunca adoptó la forma del sistema filosófico cerrado sino que lo concibió como una actividad ética e intelectual. Meditando y dialogando con sus alumnos en excursiones fue el modo en que desplegó su filosofar. No es de extrañar que ese otro «agitador de espíritus», Unamuno, viera en su amigo Francisco la encarnación del «Sócrates español»: «Nunca olvidaremos nuestras conversaciones con él, con nuestro Sócrates español, con aquel supremo partero de mentes ajenas. Inquiría, preguntaba, objetaba, obligábanos a pensar» (Unamuno, 1966: 1178). Claro que Giner, a diferencia de Sócrates, dejó una voluminosa obra escrita sobre filosofía del derecho, sociología, pedagogía o crítica literaria. Pero para él las ideas apenas tenían valor si no eran vividas, si no eran conversadas con los otros o con el paisaje. De ahí la dificultad de llevar a cabo un análisis de sus ideas pensadas y vividas. Como escribiera Manuel García Morente, «sus escritos de filosofía son como momentos inmovilizados, fragmentos arrancados violentamente» de su pensamiento (García Morente, 1922: 7). ¿Cómo resolver entonces esta aporía? ¿Tiene sentido entonces interpretar la filosofía de Giner? A pesar de esa inconmensurabilidad del concepto respecto al sustrato vital originario, cabe ensayar una reconstrucción de su filosofar a partir no únicamente de sus textos sino de los diversos testimonios que glosan su sentido vital y valor educador.

Como es sabido, el krausismo fue traído a España por Julián Sanz del Río tras su estancia en Heidelberg en 1843 y 1844. La razón por la que Sanz del Río eligió a este filósofo idealista y críptico, Krause, como referente regenerador de la sociedad española sigue siendo hoy un enigma. Lo cierto es que el krausismo fue un «estilo de vida» que influyó decisivamente en la educación, la cultura y política española, desde la Gloriosa hasta la II República. Giner confesó que la importancia del pensamiento de Sanz del Río no fue tanto el legado de una determinada doctrina ideológica como el haber representado una «corriente de emancipación espiritual» y de «austeridad ética» (Giner, 1933: 235). Algo similar podría decirse de Giner de los Ríos, aunque sin olvidar que este no fue el filósofo solitario que se retiró durante años para dar forma al krausismo aprendido durante su peregrinaje místico por tierras germánicas. A diferencia del «pensador de Illescas», como calificó Ortega a Sanz del Río en uno de los ensayos anunciados tras la publicación de Meditaciones del Quijote, Giner siempre tuvo claro que el filosofar era una actividad compartida: si el paseo fue el 
escritorio donde las ideas caminaban, el paisaje y el paisanaje fueron la biblioteca que inspiraba la meditación ética y estética:

Mas donde esa acción de influjo ético, estético, educador, en suma, del maestro se produjo con más éxito y eficacia fue en los paseos o excursiones por el campo, por los montes del Pardo, por los de la Sierra [...]. Don Francisco sentía en lo más hondo el paisaje austero y grandioso de los místicos lugares y, como nadie, sabía comunicar la emoción de su alma serena y vibrante a quienes le acompañaban, jóvenes casi siempre. Aquellos paseos — inolvidables paseos! — eran verdaderos ejercicios espirituales (Posada, 1981: 92).

Tras el fracaso político de la efímera I República, presidida por el catedrático krausista de Metafísica Nicolás Salmerón, la segunda generación krausista, liderada por Giner de los Ríos, se dio cuenta de que los cambios sociales buscados debían comenzar por la educación. "Donde hay que hacer la revolución es en las cabezas, es decir, en los espíritus». De este modo, Giner logró dar un giro práctico y educativo al krausismo, corriente filosófica que constituye un inmenso y abstracto sistema metafísico. Su labor resolvió la encrucijada del krauso-institucionismo: ni metafísica ni política. Solo a través de la educación podría alumbrarse el esperado horizonte transformador de la sociedad. Y lleva razón Pedro Cerezo al sostener que, aunque no fuera un pensador original, Giner «inflexionó el krausismo en un sentido práctico y educativo» (Cerezo, 2013: 64). Por tanto, la regeneración o la «redención» (López-Morillas) se alcanzaría a través de la educación. El humanismo ético de Giner supo combatir el fanatismo, la ignorancia, la vulgaridad o la corrupción en unos tiempos muy convulsos como los que le tocó vivir (Payo de Lucas, 2012: 73-74). La educación fue la clave para emprender esta reforma social, sin sucumbir a la tentación revolucionaria —que en su opinión no erosionaba las entrañas del mundo, apenas arañaba su superficie- y sin buscar refugio en la soledad del soliloquio metafísico.

El pensamiento de Giner, de acuerdo con la tesis de López-Morillas, «liquida el krausismo como filosofía especulativa para convertirlo en un racionalismo pragmático, en un estilo de vida» (López-Morillas, 1988: 11). Y en este giro pragmático y vitalista de la razón, habría que ver un antecedente del proyecto orteguiano de la razón vital. Partiendo de un bagaje formativo marcado por el idealismo krausista (Giner) y neokantiano (Ortega), ambos autores buscan, desde atalayas filosóficas muy diferentes, una reformulación de la razón sin excluir la vida, el cuerpo y el paisaje. Aunque Ortega nunca se tomó muy en serio la filosofía krausista —a 
juzgar por el relato de formación intelectual que describe en Prólogo para alemanes - , la influencia del racionalismo armónico pudo llegarle a partir de la lectura de Renan. Europeístas convencidos y reformadores elitistas, Giner y Ortega se distancian por igual de los sueños metafísicos —adheridos a los sistemas idealistas-y del nihilismo irracionalista que empieza a propagarse en la conciencia finisecular. Quizá por ello pueda establecerse un arco generacional de continuidad entre Giner y Ortega, pasando por encima del paréntesis que supuso el pesimismo contemplativo de la generación finisecular. Aunque esta es una cuestión que desborda claramente la pretensión de este ensayo, podría sugerirse que mientras la llamada Generación del 98 heredaría de Giner una estética del paisaje (especialmente en Azorín y Unamuno) ${ }^{1}$, en el caso de Ortega habría que añadir a esa mirada en torno a la circunstancia una importante herencia ética y política, dando forma así a una tradición liberal que muy pronto sería sepultada por el franquismo.

Tanto la Institución Libre de Enseñanza como la Generación del 14 se percibieron a sí mismas como «minorías pensantes» (López-Morillas, 1988: 60) comprometidas con la puesta en práctica del discurso regeneracionista, algo que no llegó a hacer efectivo la generación intermedia. Ortega se alejó muy pronto del pesimismo finisecular, encontrando en la figura de Giner de los Ríos un referente regenerador. Como sostuvo otro miembro de la generación del 14, Josep Pijoan, «teníamos abuelo, pero no teníamos padre espiritual». La mente sosegada de Giner huía también de los «rugidos de la desesperación» que proferían los intelectuales nihilistas. Su «obra lenta pero segura» era la educación, con el objetivo de «podar e injertar el Espíritu en los ramos tiernos de la nueva generación» (Pijoan, 2002: 59).

Tal vez Giner de los Ríos viese en el joven Ortega la posibilidad de continuar la labor regeneradora de la cultura y la sociedad. Una carta del maestro al discípulo apunta en esta dirección:

1. Podría hablarse de una influencia mutua en la relación entre Unamuno y Giner de los Ríos. En una carta del 25 de marzo de 1908, Giner le habla a Unamuno de «nuestra inmortal comunión espiritual». Años atrás, el 5 de diciembre de 1902, Giner le agradece a Unamuno que le haya enviado su libro Paisajes, dentro del cual estaba el importante ensayo «La Flecha», que causó una honda impresión en Giner. Las cartas aparecen recopiladas en el volumen editado por M. ${ }^{a}$ Dolores Gómez Molleda, Unamuno, agitador de espíritus y Giner de los Ríos, Salamanca, Universidad de Salamanca, 1976. He desarrollado el tema de la estética del paisaje en mi tesis Crítica de la razón topográfica. Génesis cultural del paisaje y la circunstancia en el joven Ortega y Gasset (Universidad de Valencia, 2007). 
Tengo toda mi vida en perpetua sacudida enfermiza entre la desesperación y la esperanza. Sí, renacemos y desde abajo, que es donde están siempre las raíces [...] Yo solo pienso en el nuevo estadio que en esa nueva sesión de fermentación ganará $\mathrm{V}$. para la espiritualidad de nuestra España [...] En VV. —y en V. personal y especialmente- está la fuerza de hoy y por tanto la responsabilidad (Giner, 1965: 133).

Si Elías Díaz estableció un posible paralelismo entre la krausista «razón armónica» y la orteguiana razón vital, en su crítica al racionalismo absoluto (Díaz, 1987: 116), posteriormente Villacañas llegó a situar a Ortega como miembro destacado de la tercera generación krausista, no tanto por afinidades filosóficas sino por la voluntad de reformar intelectual y moralmente la sociedad española (Villacañas, 2004: 116).

Pero más allá de esta continuidad regeneracionista entre ambas generaciones, un análisis de algunos de los ensayos ginerianos dedicados a la filosofía anticipa parte de la crítica que realizará Ortega al idealismo. Las ideas pierden todo su valor si no se ponen en conexión con su horizonte vital; no son un producto exclusivo de la razón sino que surgen desde el paisaje circundante.

En «Cómo empezamos a filosofar» (1887), sostiene Giner que el pensamiento "no es una esfera distinta y aun opuesta a la vida». No darse cuenta de ello supone incurrir en posiciones dogmáticas y doctrinarias. De ahí que las cosas y el mundo circundante sean para Giner el inicio de toda actividad intelectual. Si el filosofar nace del diálogo con el mundo, la belleza surge en contacto con la naturaleza. Solo después, reflexionando en torno a un ensayo filosófico o una obra de arte, se despierta en el educando un "espíritu crítico» ante el pensamiento o la estética de otros. Pero nunca el «comercio [...] con el pensamiento ajeno a nadie hará filósofo» (Giner, 1973: 145).

De acuerdo con el dictum kantiano, aprender a filosofar sería más importante que el conocimiento de la historia de la filosofía. "Aprender Filosofía" es ante todo aprender a filosofar», escribe Giner en otro texto esencial, «La enseñanza de la Filosofía». En él, Giner atribuye a la filosofía una función práctica en la medida que se trataría de un saber que enseña a vivir y a actuar. La pedagogía filosófica, al igual que el resto de materias y disciplinas, ha de estar sometida a este imperativo práctico y vitalista: «Se nos enseña a formarnos ideas de las cosas, a ver, a oír, a pensar, a andar, a manejar un instrumento, a hablar, a exigir, a hacer, a evitar, a guardar tales o cuales reglas de conducta: en suma, vivir y obrar. Toda enseñanza 
lo es, pues, de cosa práctica: tan práctico es pensar, como cavar la tierra» (Giner, 1973: 153).

Siguiendo la estela de otros autores, como Epicuro o Montaigne, Giner concibe la filosofía como una actividad, como una forma de vivir y actuar desde la reflexión y el pensamiento. Frente a la tradicional oposición entre saberes teóricos y prácticos, la pedagogía institucionista quiso disolver ese antagonismo. Es en este sentido en el que habría que entender que tanto el pensamiento como el cultivo de la tierra sean dos experiencias prácticas que modulan una filosofía de vida donde la razón y el sentimiento, la inteligencia y la voluntad no se excluyen sino que se integran y dialogan en una filosofía de la vida armónica. Como el jardín de Epicuro, el campo puede ser un lugar para cultivar hortalizas y pensamientos. Y es que, para Giner, «todas las enseñanzas deben darse con preferencia al aire libre» (Giner, 2011: 156). También la propia actividad filosófica, que en muchas ocasiones se despertaba en el transcurso de una excursión o ante la contemplación del paisaje. Pero, ¿en qué consistiría filosofar para Giner? Aprender a filosofar supondría «aprender a investigar y hallar relaciones, aspectos, problemas, que trascienden, no solo del conocer sensible, sino de cada particular objeto, y lo enlazan gradualmente con otros y con todos hasta reconocerlo lo más completamente posible como un objeto de valor y trascendencia universales» (Giner, 1973: 153).

Pero para Giner la «función del filósofo no es crear los movimientos ideales que en cada sociedad se desenvuelven» (López-Morillas, 1988: 62). Es decir, el filósofo debe renunciar a una metafísica de lo absoluto. Su labor crítica y reflexiva surge del «espíritu del tiempo» con la intención de modificar el entorno. La educación filosófica de Giner persigue extraer el pensamiento de las cosas y no solo de las doctrinas filosóficas: «Cuando halla el espectador harto más realidad en el objeto que en las concepciones de un Platón o de un Hegel, harto más que ver en la sociedad y el Estado que en los libros de Aristóteles, Montesquieu o Stuart Mill» (Giner, 1973: 146).

Se trata, pues, de iniciar el filosofar en la realidad, el bien y la justicia en la sociedad y en sus instituciones, y la belleza en la naturaleza. Pensar es saber mirar desde el asombro: aprender por sí mismo (sapere aude), atreverse a mirar el mundo que nos rodea sin la tutela ajena. Y ello ha de hacerse sin olvidar que las cosas no coinciden con el pensamiento, como sostiene el idealista. El pensamiento no puede reemplazar a la experiencia, la idea no puede eliminar la sensación. Lo que representa el sujeto en su actividad intelectual «es solo una visión, aunque directa, en parte errónea 
y siempre limitada de su inagotable realidad». La realidad no solo es pensada a partir de perspectivas singulares sino que, además, la expresión de esas ideas también es particular: «La riqueza interior de nuestras representaciones, que son ya una visión finita del objeto, fluctúa constantemente, desvaneciendo y deformando sus límites para responder de algún modo, a fuerza de sustituir unas por otras, a la inabarcable riqueza de la realidad» (Giner, 1973: 147).

En el fondo, estas reflexiones de Giner ponen de manifiesto la relación entre pensamiento y vida, teoría y práctica: «Y es que la teoría auxilia fundamentalmente la práctica, la dirige, la fecunda, hasta la hace posible, pero no la substituye» (Giner, 2011: 41). A través de la educación pretenderá Giner superar el «irracional divorcio entre teoría y práctica» que afecta a la mayoría de filósofos, científicos, políticos y demás intelectuales. El pensamiento vivo, cuyas ideas no mueren perdidas en el laberinto solipsista de la conciencia, adquiere una dimensión práctica y ética porque «trasciende y se realiza en el mundo y en la sociedad» (Giner, 1973: 168).

\section{La educación y el arte de ver el paisaje}

La Institución Libre de Enseñanza combatió el intelectualismo estéril — «antiguo intelectualismo dogmático y verbalista», lo denomina Ginerque reinaba en las aulas, buscando una educación integral y armónica que cultivase en equilibrio la razón y la voluntad, la ética y la estética. De acuerdo el Ideal de la humanidad krausista, compartido por Sanz del Río y Giner, el ser humano sería un todo unitario e inseparable de espíritu y cuerpo, ciencia y arte: «Debe, pues, el hombre, educado en el puro y entero sentido humano, abrazar en unidad la esfera de la ciencia y el arte [...] Hombre no quiere decir solo cuerpo y espíritu en simple compañía, uno al lado de otro, sino en libre armonía y omnilateral comercio, en intimidad de vida, de fuerzas y de expresión» (Krause / Sanz del Río, 1985: 101 y 103).

Más allá del dualismo platónico y cristiano, el racionalismo armónico y vitalista de Giner busca la integración no excluyente. El antídoto contra el dualismo lo brinda «el arte de vivir, en que ética y estética, valor moral y buenas maneras encuentran su reconciliación y armonía» (Cerezo, 2013: 57).

La vida, como en Nietzsche, adquiere la forma de una obra de arte. Y la pedagogía para Giner constituye el arte del desarrollo armónico de la persona donde el maestro, «en el choque y contraste de su pensamiento con el discípulo, sacude en este el ánimo apocado y le despierta al ansia de la 
razón» (Giner, 1973: 34). Las ideas y la reflexión que despierta el diálogo mayéutico con el maestro ha de «inspirar la conducta», transformando el pensamiento en acción.

Lo que busca Giner son «escolares activos que piensan, que hablan, que discuten, que se mueven, que están vivos». En este mismo texto, «El espíritu de la educación en la Institución Libre de Enseñanza», Giner se lamenta del espectáculo escolar de ver a «jóvenes macilentos, consumidos por una vejez prematura, víctimas de un intelectualismo despótico, sin vitalidad, sin salud, sin alegría, apartados de la Naturaleza, de la sociedad y aun de sí propios» (Giner, 1973: 107-108). La pedagogía activa del institucionismo considera que la instrucción teórica no tendría sentido si no formase parte de una educación integral; para ello la memoria y la inteligencia han de cultivarse junto a otras facultades esenciales, como la imaginación, la voluntad, la conciencia moral, la sensibilidad estética y la salud física, que no suelen ser atendidas en el medio educativo. Así Giner considera que «la inteligencia por sí misma, da luz, no calor» (Giner, 1973: 169), anticipando en un siglo las teorías de las inteligencias múltiples (Howard Gardner) y emocionales (Daniel Goleman). Se trata, pues, de subordinar la instrucción a la educación. Y como escribiera el amigo y principal discípulo de Giner, Manuel Bartolomé Cossío, «[e]ducar antes que instruir; hacer del niño, en vez de un almacén, un campo cultivable» (en López-Morillas, 1988: 191).

En la escuela se enseñan muchas cosas pero se olvida lo esencial: enseñar a pensar y a vivir. Los dos principales problemas de la educación son, según Giner, los siguientes: considerar que el «elemento intelectual» es el único que interviene en el proceso de aprendizaje y enseñanza; y, consecuencia de lo anterior, el predominio de una educación «casi exclusivamente, pasiva, asimilativa, instructiva», que no procura el desarrollo de la espontaneidad, la originalidad, la inventiva. Así, el maestro suele limitarse a poner a prueba la memoria y la inteligencia del educando, recurriendo al «procedimiento usual de estampación» en su mente, pero dejando a un lado esas otras facultades antes mencionadas. La educación integral, autónoma, activa y crítica pasa, además, por la sustitución de la lección magistral — «sistema de mera exposición» y «discurso»— por el diálogo socrático: «conversación familiar, práctica y continua entre maestro y discípulo» (Giner, 1973: 87).

El maestro ha de ser «a la vez maestro y discípulo». Sin deseo de aprendizaje ni de renovación, el maestro acaba languideciendo en sus rutinarias tareas de transmisión y estampación de contenidos en sus alumnos. Quien 
pretenda enseñar a dudar, deberá empezar a cuestionar sus propios métodos de enseñanza, buscando y experimentando diferentes caminos en la filosofía de la educación: Locke, Rousseau, Pestalozzi, Herbart, Froebel, Spencer y Dewey son algunos de los referentes que aparecen en la obra de Giner.

El aprendizaje del educando no comienza en las "palabras del maestro», sino en las cosas mismas que forman parte del entorno educativo. Lo que rodea al niño: el espacio del aula, el jardín, el huerto, el campo escolar, el camino que lleva a la escuela. «No es posible tolerar que los niños permanezcan horas y horas seguidas en un local cerrado» (Giner, 2011: 154). En este «epicureísmo institucionista» (García-Verlasco, 2013: 152) el paisaje educa antes que las ideas. La dimensión paisajística de la educación resulta esencial para el «esparcimiento de su imaginación —que también pide espacio»—, estimulando así la creatividad y la fantasía del niño.

Para aprender a mirar la naturaleza, Giner propone un proceso que se iniciaría en la contemplación directa del mundo. En ese instante debemos dejarnos llevar por la curiosidad y la libre observación. Después, la mirada se sumerge en otros paisajes pintados o escritos, que nos enseñan a ver la naturaleza de otro modo. Ese bagaje cultural va dando forma a nuestra sensibilidad. Pero el verdadero disfrute de lo visto acontece cuando nos distanciamos de esos otros paisajes culturales, cuando evitamos que ellos se apoderen de la escena contemplada. Al final de esta pedagogía del paisaje alcanzaríamos una autonomía estética:

De tal modo en que llega un día en que, prescindiendo del mérito del artista y atendiendo solo a la función de su obra, hallamos que la pintura de paisaje [...], por fiel y noblemente que interprete la belleza del campo, es una simple nota de atención, un estímulo para que nos representemos interior y libremente cien y cien originales llenos de varonil realidad, de encanto y de poesía, en cuya comparación el cuadro del más grande artista palidece (Giner, 1973: 145).

Es decir, que el sentido estético nace en la naturaleza y se cultiva en el arte para, después, poder captar mejor la belleza del mundo. El arte sería, según Giner, "una preparación para el natural”, en el amplio sentido del mundo exterior, ya físico, ya social: una educación que nos enseña a verlo, a penetrar y a sentir sus delicadezas» (Giner, 1973: 162).

Tanto Giner como Cossío estaban convencidos de que educar consistía en el arte de hacer ver: "Las tres cuartas partes, y aun es poco, de lo que sabe un hombre culto, no lo aprende en los libros, sino viendo las cosas, quiero decir, sabiendo verlas» (Cossío, 1985: 19). Se trata, pues, de 
aprender a mirar la circunstancia más próxima, dentro y fuera del aula. A partir del método intuitivo, el educando forja su sensibilidad y reflexión autónoma. Al igual que Nietzsche, los institucionistas creían que la educación de la mirada eran tan importante como la lectura o escritura: «Se ha de aprender a ver, se ha de aprender a pensar, se ha de aprender a hablar y a escribir» (Nietzsche, 1996: 84). El autor de Así habló Zaratustra critica el prejuicio intelectualista de la educación que desconfía de la imagen y deposita toda su esperanza en la palabra.

Y ese «arte de hacer ver» fue el que se cultivó en las excursiones institucionistas. En el valle del Manzanares, junto al Palacio del Pardo, Giner salía a pasear los domingos con amigos y discípulos. En las conversaciones que tenían mientras recorrían esos parajes, relatadas desde el recuerdo de Pijoan, llama la atención la diferente sensibilidad con que vivían el paisaje. Los acompañantes percibían el paisaje como un fondo o escenario donde reflexionar y debatir. Para Giner esto era secundario: mientras hablaban y hablaban, ensimismados en sus propias ideas y creencias, el paisaje se les escapaba. En ocasiones, Giner les apremiaba para que mirasen y escuchasen el paisaje: «¡Escuchen ustedes al cuclillo que canta! ¡Miren este cielo azul! Vivamos, vivamos; gocemos de este vivir como gozan de él todas las demás cosas...» (en Pijoan, 2002: 72).

Ese ideal místico de fusión con el paisaje fue expresado por Giner una tarde que paseaba con Pijoan en Barcelona. Estando junto al mar, le dijo: «Yo no quisiera humanizar al Océano —añadió suspirando-, sino ser como él. Solo entonces comprendería su esencia» (Pijoan, 2002: 109). Para captar el paisaje hace falta despojarse de toda cultura y palabra. Tan solo mirar, escuchar y sentir en silencio. Devolver el paisaje a la naturaleza, desidealizarlo. Es así como cobra sentido ese imperativo estético que Giner propuso ante el paisaje: «Mira y goza».

Para Ortega, en cambio, el paisaje lo lleva uno puesto de casa, como le comentó Giner en una de las excursiones que realizaron juntos:

Poco antes yo había manifestado mis opiniones sobre el paisaje y don Francisco Giner habló así: - Yo no pienso como usted, pero como usted pensaba aquella admirable mujer, doña Concepción Arenal. No olvidaré nunca que en cierta ocasión me decía: Desengáñese usted, con los paisajes ocurre lo que en las posadas de aldea. Cuando llega el viajero y pregunta a la posadera: «¿Qué hay de comer?», la posadera contesta: «Señor, lo que usted traiga». Pues esto es el paisaje; lo que cada cual traiga (Ortega, 1988: 48). 
A pesar de esas diferencias, acentuadas tras el descubrimiento de la fenomenología, el joven Ortega heredó el espíritu gineriano del paisaje en escritos anteriores a Meditaciones del Quijote (1914). De Giner aprendió Ortega el valor pedagógico y místico del paisaje. En algunos de sus primeros ensayos, como «La pedagogía del paisaje» (1906), Ortega despliega un diálogo filosófico con un interlocutor imaginario, Rubín de Cendoya, con el que camina «por las lomas nerviosas del Guadarrama» (Ortega, 1983: I, 53). El personaje de Rubín de Cendoya, inspirado en la figura de Giner, es presentado en otro texto como un místico español, cuya dedicación preferida es la «estética espacial» (Ortega, 1983, I: 434).

El paisaje enseña a ver y a ser; trasmite virtudes como la sinceridad y la serenidad. Rubín de Cendoya, al igual que Giner, piensa que el paisaje enseña antes que las ideas: «cada paisaje me enseña algo nuevo y me induce una nueva virtud. En verdad, te digo que el paisaje educa mejor que el más hábil pedagogo» (en Ortega, 1983, I: 54).

Como he desarrollado en otro lugar (Navarro de San Pío, 2011: 151172), este panteísmo spinozista que comparten Giner y Ortega tendría ciertas afinidades estéticas con la filosofía del paisaje de Emerson y Thoreau. Tanto Emerson como Giner se convirtieron en pedagogos del paisaje para las generaciones trascendentalista e institucionista, respectivamente. En torno a Concord y al Guadarrama se expandió una cultura del paisaje que modeló la sensibilidad vital e intelectual de pensadores, poetas y científicos. Caminar y conversar con la naturaleza se convirtieron en tareas esenciales para el conocimiento de sí mismo y del mundo circundante.

El paisaje, además de transmitir valores éticos y estéticos, es símbolo de identidad individual y colectiva. Giner y los institucionistas hicieron de la Sierra del Guadarrama un poderoso símbolo identitario y existencial heredado por las generaciones sucesivas. Pero fue Ortega quien articuló filosóficamente, a través de su razón topográfica, esa cultura del paisaje iniciada por Giner de los Ríos: «Mi salida natural hacia el universo se abre por los puertos del Guadarrama o el campo de Ontígola. Este sector de realidad circunstante forma la otra mitad de mi persona: solo al través de él puedo integrarme y ser plenamente yo mismo» (Ortega, 1983: I, 322).

Giner y Ortega devolvieron la mirada al paisaje, absorta hasta entonces en lejanos y difusos mundos metafísicos. «Mira y goza», sugería Giner; mientras que Ortega buscaba «posibles maneras nuevas de ver las cosas» (modi res considerandi) que no desatendieran la realidad más inmediata. Una cultura viva ha de despertar del ensimismamiento intelectual, asumiendo que las ideas, aisladas de su horizonte vital y paisajístico, nacen ya 
muertas. La tragedia de la cultura acontece, según Simmel, cuando el régimen intelectual acaba siendo enemigo de la vida: cuando pensamos que el paisaje se da solo en el arte y no en la naturaleza más próxima, cuando creemos que no hay más filosofar que el que cabe en la historia de la filosofía, cuando educar se reduce a una estampación de conocimientos. De ahí que la regeneración cultural y social pasara, para Giner y Ortega, por un nuevo equilibrio armónico entre razón y sensibilidad, ciencia y arte, pensamiento y vida.

\section{Bibliografía citada}

Cerezo Galán, P., «Giner de los Ríos, el "Sócrates español". De la política a la pedagogía», en AA. VV., La Institución Libre de Enseñanza y Francisco Giner de los Ríos, II: La ILE y la cultura española, Madrid, Fundación Francisco Giner de los Ríos / Acción Cultural Española, 2013.

DíAz, E., «Ortega y la Institución Libre de Enseñanza», Revista de Occidente, 68 (1987), pp. 113-127.

G[ARCía] M[OREnTE], M., «Introducción» a Francisco Giner de los Ríos, Estudios filosóficos y religiosos [Obras completas, VI], Madrid, La Lectura, 1922.

GARCÍA-VELASCO, J., «Giner y su descendencia. La Institución Libre de Enseñanza y la cultura española contemporánea», en AA. VV., La Institución Libre de Enseñanza y Francisco Giner de los Ríos, II: La ILE y la cultura española, cit. supra.

GINER DE LOS Ríos, F, Estudios sobre educación [Obras completas, VII], Madrid, Espasa-Calpe, 1933, 2. ${ }^{a}$ ed.

— «Carta a Ortega» [13 de mayo de 1911], Revista de Occidente, 23 (1965), pp. 125-133.

- Ensayos, ed. Juan López-Morillas, Madrid, Alianza, 1973.

- Educación y enseñanza, Madrid, Espasa, 2011.

Gómez Molleda, M. ${ }^{a}$ D., Unamuno, agitador de espiritus y Giner de los Ríos, Salamanca, Universidad de Salamanca, 1976.

KRAUSE / SANZ DEL Río, Ideal de la humanidad para la vida, trad. y adapt. Julián Sanz del Río, Barcelona, Orbis, 1985.

LóPEZ-Morillas, J., Racionalismo pragmático: el pensamiento de Francisco Giner de los Ríos, Madrid, Alianza, 1988.

NAVARRO DE SAN Pío, J., «La sombra mística del paisaje orteguiano: Giner de los Ríos y Emerson», Revista de Estudios Orteguianos, 22 (2011), pp. 151-172.

Ortega y GASSET, J., Obras completas, Madrid, Alianza / Revista de Occidente, 1983. 
— «Temas del Escorial», en Notas de andar y ver: viajes, gentes y países, Madrid, Alianza, 1988.

PaYO DE LuCAS, J., La antropología de Giner de los Ríos: en busca de la libertad democrática, Madrid, Dykinson, 2012.

Pijoan, J., Mi Don Francisco Giner (1906-1910), intr. O. Ruiz-Manjón, Madrid, Biblioteca Nueva, 2002.

Posada, A. G., Breve historia del krausismo español, Oviedo, Universidad de Oviedo, 1981.

UnAmuno, M. de, «Recuerdo de don Francisco Giner», en Obras completas, III, Madrid, Escelicer, 1966.

Villacañas, J. L., «Introducción»a J. Ortega y Gasset, Meditaciones del Quijote, Madrid, Biblioteca Nueva, 2004.

Fecha de recepción: 17-6-2015

Fecha de aceptación: 1-12-2015 



\title{
«UN SANTO DE CORTE HISPÁNICO»: GINER DE LOS RÍOS Y EL ESPECTRO DEL SUJETO ESPAÑOL
}

\author{
ANTONIO DE MurCia CONESA \\ Universidad de Alicante
}

\section{Resumen}

Este artículo estudia la relación de la obra de Giner de los Ríos con el problema del sujeto español desarrollado, en oposición al individualismo moderno, por algunos de sus discípulos como Américo Castro. Se examina la presencia de este sujeto colectivo, bajo la forma de «espíritu social» o «sentido común histórico», en tres aspectos distintos de la obra de Giner: su idea de tradición literaria nacional, que influyó notablemente en los trabajos de historiadores y filólogos posteriores; su concepción organicista del derecho y de la inmanencia social de la soberanía política, presente en la noción de derecho consuetudinario y de opinión pública, y su idea sublime del sujeto de la educación, objeto principal de su labor pedagógica. Estos aspectos guardan una estrecha relación con el tópico del pensamiento en acción y la imagen de ascetismo que ha dominado la recepción de Giner de los Ríos.

Palabras clave: sujeto español; individualismo moderno; persona social; organicismo; spencerismo; pedagogía institucionista; soberanía política; sublime; opinión pública; derecho consuetudinario; krausismo; pensamiento conservador; metafísica del derecho; Américo Castro; estado latente.

\begin{abstract}
This paper explores the relationship between the work of Francisco Giner de los Ríos and the problem of the Spanish subjectivity which, in opposition to modern individualism, was studied by some of his followers as Américo Castro. The presence of a collective ego, in the form of «social spirit» or «common historical sense», is examined in three aspects of the work of Giner: his idea of national literary tradition, which significantly influenced the works of historians and philologists; his organic conception of the social immanence of political sovereignty, present in its notion of customary law and public opinion; and his sublime idea of the Spanish self, main
\end{abstract}

Anales, 27 (2015), pp. 59-80

DOI: 10.14198/ALEUA.2015.27.04 
subject of his educational work. All these aspects will be discussed in relation to the topic of thinking in action and the image of asceticism that has dominated the reception of Giner de los Ríos.

Keywords: Spanish Self; modern individualism; social person; organicism; spencerism; pedagogy; sublime; political sovereignty; public opinion; customary law; krausism; conservative thought; metaphysics of law; Américo Castro; latency.

\section{Introducción}

«Astucia de lo inconsciente» es una expresión de Eduard von Hartmann que Giner de los Ríos utilizó ocasionalmente, en una nota sobre Spencer, para explicar los imprevisibles efectos de la acción individual en sociedad y el enmarañado «encadenamiento de toda obra con el sistema general de las causas y efectos en el mundo» (Giner, 2015: 352). Al proponer como caso ejemplar el contraste entre los efectos provocados por las obras de Spencer y los probables propósitos que este albergaría al escribirlas, acertó, al menos, en lo que a la recepción española del positivista británico se refiere. Pero la expresión, de cuño más metafísico que psicoanalítico, podría aplicarse también a la propia obra de Giner y a su relación con la sociedad española. Inconsciente frente a inconsciente, o astucia por astucia, su irregular recepción durante un siglo ha dado lugar a imágenes encontradas, que lo convierten en enemigo extranjerizante del sujeto nacionalcatólico, educador modélico de un sujeto liberal de cuño ilustrado - por el que en realidad sintió escasa simpatía-; o mentor paradigmático de un derrotado sujeto republicano, entre otras.

Con independencia de las aleccionadoras imágenes del individuo Francisco Giner, su magisterio y su obra escrita fueron una constante referencia, no siempre explícita, en las posteriores tentativas por describir un sujeto general de la historia y la cultura españolas: una forma peculiar de subjetividad colectiva, entendida siempre en confrontación con el moderno individualismo europeo.

Las páginas que siguen examinan la heterogénea presencia en la obra de Giner de esa idea de un hispánico sujeto colectivo, como espíritu social y como sentido común histórico. Una presencia que casi siempre es negativa: en oposición a otros modelos de sujeto, o como una ausencia - un espectro- - y una meta cuyo logro sería la principal misión de una larga y tenaz labor educadora. Sus efectos en la obra de Giner pueden apreciarse, como veremos, en tres aspectos de esta que resultan inseparables: su prolongada influencia sobre el ensayismo en torno al tópico del problema de 
España, cultivado por algunos de sus mejores discípulos; su concepción organicista del Derecho y del Estado; y el proyecto pedagógico de la Institución Libre de Enseñanza.

En todos ellos, esa latente subjetividad común —idea regulativa y constitutiva del pensamiento de Giner- se revela como un dispositivo para la armonización de contrarios: lo individual y lo social, lo natural y lo histórico o la teoría y la acción.

\section{La «doctrina en el vivir»: el mito del pensamiento en acción}

En unas páginas dedicadas a la figura intelectual y educativa de Alberto Jiménez, a cuento de un libro sobre Juan Valera y la generación de 1868 («De grata recordación: Juan Valera y Alberto Jiménez»), Américo Castro incluye una digresión sobre su viejo maestro, Francisco Giner, que eclipsa el resto del artículo (Castro, 1975 [1957]). Además de inevitable mentor, Giner comparece aquí como paradigma de una intelectualidad española abocada a la dispersión. Entre los siglos XIX y XX, las inteligencias espontáneas e inagotables de un Valera, un Cossío o del mismo Jiménez, incapaces de sistematizar sus grandes intuiciones en un programa teórico y acuciadas por las urgencias prácticas del momento, se vieron abocadas al nomadismo diplomático, la conversación brillante o la construcción de refugios intelectuales como la Residencia de Estudiantes. En Giner, la ausencia de una obra redonda, que expresara con nitidez y decisión su «pensamiento radical», cobraba a ojos de Castro, como de buena parte de los epígonos del maestro, un superior valor pedagógico y filosófico. En primer lugar, en relación con su apostolado educativo, en el que, dos décadas antes del citado artículo, don Américo había visto redivivo «el ardor de nuestros cazadores de almas del siglo XVI» (Castro, 1975 [1937]). En segundo lugar, por su encarnación de la mejor intelectualidad hispánica: aquella cuyos protagonistas ofrecían «el espectáculo de cómo iba proyectándose la doctrina en el vivir».

A la imagen de un sabio entregado a moldear la cultura española desde la formación integral de sus sujetos más jóvenes se une la de un ascético estudioso, solitario, capaz de internacionalizar el pensamiento español abriéndolo a la mejor ciencia extranjera: más allá del clerc francés o del excitator patrio de cuño germano, Giner, educador, es también el gran mediador, el medium capaz de cerrar las fisuras entre el pasado y el presente o entre el individuo y la colectividad ${ }^{1}$. Y eso no sería consecuencia

1. Américo Castro desarrolla esta noción del investigador como medium en su Ensayo sobre historiología. Analogías y diferencias entre hispanos y musulmanes (1950). 
de la sistematización y clausura de su obra escrita, sino de la capacidad para proyectar en ella su misma acción. Que los pragmata se subordinen a los logoi, y la vida a la propia escritura, choca con la biografía humilde de un profesor que, indiferente a su probable olvido, escuchaba atentamente las ocurrencias de los muchachos que, como Castro, le seguían por las cumbres de Guadarrama. La conjunción de tenacidad vital y renuncia personal se ajusta al aura más o menos redentora que ha nimbado la imagen del fundador de la Institución Libre de Enseñanza. Castro lo dijo en varias ocasiones: «En el fondo fue un santo de corte hispánico» (1975: 164).

Esta sentencia hagiográfica evoca, además del carácter de religión laica que aún hoy se atribuye al institucionismo (García Cárcel, 2011: 438), la fe en una vaga pero convencida salvación por la acción, que el autor de España en su historia consideraba rasgo sobresaliente del sujeto hispánico. Con una fe parecida, solventes intérpretes resumen el valor específicamente filosófico de la obra de Giner con el retrato apasionado de un filósofo en acción (Capellán, 2015: 21-34). Los argumentos extraídos de sus obras jurídicas, sociológicas, estéticas y pedagógicas para justificar esa imagen no han sido más importantes que los relatos sobre el excepcional ethos quijotesco con que el rondeño habría templado su «racionalismo pragmático» (López-Morillas, 1988: 9-12), dentro y fuera del krausismo. El relato repetido de las vicisitudes de ese pensamiento en acción, evidente tanto en el entusiasmo por mejorar el mundo como en el escepticismo ante la imposibilidad de conseguirlo, ha funcionado como un mito de obligada referencia, no en el sentido de una ilusión infundada, sino en el de una imagen fundadora con la que reinterpretar y compensar los derroteros perdidos de la tradición filosófica y científica española y el olvido al que fueron condenados sus mejores defensores e instituciones, incluida la ILE. Algunos de los que han lamentado ese olvido han intentado enmendarlo recuperando su singular sujeto histórico o, más bien, transhistórico. Castro no fue desde luego una excepción: más aún que Pidal y otros discípulos, vio en Giner de los Ríos una figura clave para rescatar a ese singular sujeto de sus cenizas.

\section{El yo español y el sentido común histórico}

En la conferencia con que inauguró su primer curso en la Universidad de Princeton (1941), el exiliado Castro, dispuesto a mostrar al público ilustrado de Norteamérica la excepcionalidad cultural y ontológica que había llevado a España hasta su reciente guerra civil, y que, paradójicamente, podría conducirla a su salvación, invocaba la autoridad de Giner de los 
Ríos. Tras asegurar que "[e]l yo español no es el del cogito ergo sum», sino «el de La vida es sueño de Calderón» y el de Cervantes, proseguía su descripción de ese yo con igual rotundidad:

un ego que prolonga la voluntad de la existencia en las direcciones más opuestas, pues piensa que las actitudes exclusivistas o parciales le llevarán a laberintos inacabables. Es el yo de Francisco Giner, que quería para España un presente que fuese al mismo tiempo su pasado tradicional y su espléndido futuro. O el de Goya, en el que convivían belleza y horror, infierno y paraíso... Y el de Lope, con su amor y su deber (Castro, 1976: 30).

El resto del discurso presenta notables afinidades con los argumentos que Giner escribió mucho antes en un trabajo especialmente apreciado por Castro: La política antigua y la política nueva. La crítica suele interpretarlo en el marco de la metafísica jurídica del krausismo bajo su singular modulación hispánica. Ciertamente no puede leerse sin tener en cuenta las doctrinas aprendidas de Sanz del Río y sobre todo de Ahrens, y sus particulares concepciones sociológicas alimentadas por la metafísica positivista de Comte, la teoría de las multitudes de Tarde o el darwinismo spenceriano, entre otras fuentes. Volveremos más adelante a este importante texto y a sus distintas lecturas. Lo importante en relación con el discurso de Castro es su significación para el problema de la subjetividad que acució al ensayismo sobre lo que se ha llamado «problema de España» y que don Américo encarnó de forma modélica. Su aspiración, como la de Giner, era defender y difundir el conocimiento de una forma de subjetividad que, en contraste con las líneas del individuo moderno, cartesiano, archicientífico, maquiavélico y, a la postre, kantiano, revelaría una suerte de Sonderweg, una vía especial de la cultura española cuyo reconocimiento definitivo podría superar o aliviar la conciencia de la crisis: una conciencia que en Giner era con frecuencia agónica y difícilmente curable por las ensoñaciones krausistas de lo absoluto (Giner, 2015: 214 ss.). Esa vía, transitada literariamente por notables humanistas formados en la Junta de Ampliación de Estudios, fue abierta por las síntesis conceptuales del maestro de Ronda.

La inmanencia de la soberanía política en el todo social o, más exactamente, la persona social, que Giner intentó justificar con minuciosa reiteración, acredita una prodigiosa habilidad para integrar las doctrinas más heterogéneas, propia de lo que ha venido en llamarse «krausismo positivo» (Núñez, 1987: 47-64). Los argumentos ontológicos y antropológicos que sostuvieron esos ensayos de integración, no obstante formularse como 
correspondencia entre la soberanía del Estado y la del individuo, tuvieron una proyección más duradera en los estudios histórico-literarios que en los jurídico-políticos. Cuando el krausismo jurídico era un fenómeno intelectual casi olvidado, seguían publicándose apasionadas tentativas por demostrar la singularidad de los españoles en la literatura y en la historia, o el «centaurismo» (Castro, 1996: 206- 210) latente de una cultura que, desde la Edad Media, habría armonizado sin resquicios la exterioridad con la interioridad y el pasado con el presente. Esa hermenéutica nacional seguía la huella, o, más bien, el espectro de un «sentido común histórico», que décadas antes Giner había justificado «por la compenetración irreflexiva de todas las actividades sociales que, cruzándose en múltiples direcciones según leyes desconocidas u olvidadas por los colaboradores de la misma cultura general, forman la trama de esta» (2015: 198).

Conceptualizar la realidad jurídica y social de la subjetividad portadora de ese «sentido común histórico» requería rastrearla en el resto de esferas que forman la historia hispánica como totalidad. Semejante tarea, sin perjuicio del firme rechazo a las mitologías de la historiografía española (López-Morillas, 1988: 33-42), no podía llevarse a cabo sin una estetización de categorías jurídicas, políticas e historiográficas. Con ese horizonte por delante, una parte central de la obra de Giner puede ser leída como la persecución de un ideal de absoluto jurídico, que, encauzado en un proyecto de reeducación de la subjetividad española, comparte las formas de lo absoluto literario, y que, como se argumentará más adelante, cristaliza en el ideal de un sujeto de lo sublime, encarnado en el pueblo español.

\section{Los «poderes latentes»: del derecho consuetudinario a la opinión pública}

Las referencias más explícitas de Giner al problema del sujeto aparecen en el marco de su concepción del Derecho y del Estado y, más concretamente, en sus intentos por armonizar la autonomía del individuo con su determinación como órgano jurídico. La etimología de subjectum, sobre todo en La persona social (Giner, 2015: 299 ss.), lo remite a la sumisión ontológica y moral del individuo al género, y del hombre particular al hombre ideal. El término, para Giner — como para Joaquín Costa o los discípulos Alfredo Calderón y Adolfo Posada - expresaría la sujeción, inherente a la naturaleza del Estado, que hace a la persona individual soberana y súbdita al mismo tiempo. Toda su reflexión acerca del problema de la soberanía y la representación política gira en torno a esta idea de «hombre sujeto» (Vázquez-Romero, 2009: 49 ss.), inseparable de la tesis de la inmanencia 
del derecho, pero también de la mencionada hipótesis, convertida en hipóstasis, de un «sentido común histórico». Giner localiza al subjectum sociológico en el espacio de correspondencias entre la persona individual y la persona social, y justifica la necesidad de su existencia jurídica en el sometimiento de la política al derecho, o, más exactamente, de la filosofía política a la filosofía del derecho. Pero cuando trata de apuntalarlo históricamente sus conceptos se cruzan con las categorías literarias, que nutrieron las posteriores síntesis sobre la tradición hispánica.

Estas síntesis han sido interpretadas como expresión de un nacionalismo heredero del alemán, que el fundador de la Institución Libre de Enseñanza compartió con su maestro Sanz del Río, con Fernando de Castro y con todos cuantos de un modo u otro contribuyeron a una antropología histórica del carácter español (García Cárcel, 2011: 439 ss.). Aunque sesgada, la etiqueta nacionalista es eficaz para entender algunas derivas del pensamiento liberal y el rechazo que encontró en el tradicionalismo neocatólico por parte de quienes, como Menéndez Pelayo, anteponían estética y culturalmente la idea de Imperio a la de nación. La que el erudito cántabro llamaba «infección de la enseñanza» de los institucionistas (Menéndez Pelayo, 1992: 1388), extendió entre sus mejores alumnos una decidida inclinación a buscar los rasgos etnoformadores de comunidad, que culminaría Menéndez Pidal y proseguiría, por vías más sinuosas, Américo Castro. La perspectiva que da la obra del primero permite apreciar históricamente el alcance de esa inclinación, especialmente en las reconstrucciones de la tradición literaria española, que dieron a parar en la celebrada y espinosa noción de «estado latente».

Como es sabido, la fórmula posibilitaba a Pidal, por una parte, articular la gramática histórica con la historia literaria y, por otra, reconducir esta a la historia nacional prescindiendo de argumentos míticos tan enojosos para él como para los miembros de la Institución. Con ese sustrato que «presiona sobre las fuerzas actuantes en cada momento», propiciando lentos cambios fonéticos cuya lucha con los usos antiguos dura «muchos cientos de años y aun milenios», Pidal extendía su explicación morfodinámica de los cambios idiomáticos a la evolución de las formas poéticas comunes a través de un mismo medio ecológico: el pueblo, «base de toda la producción literaria de un país, como el terreno donde toda raíz se nutre, y del cual se alimentan las más exóticas semillas que a él se lleven» (Menéndez Pidal, 1963: 129-152).

No es el de «nación» un concepto habitual en Pidal, sino el de «pueblo»; tampoco lo fue en Castro, que, utilizó con más entusiasmo el de 
«civilización». «Pueblo» era una evidente herencia del viejo Volk romántico que, más sensible a los rasgos latentes de la cultura, permitía sustituir la artificiosa dimensión política de la estructura nacional por la natural pureza de la forma popular. «Civilización», más cercana al concepto de Rafael Altamira que al de Oswald Spengler, se ajustaba a un sujeto de la historia entendido como vital, antes que institucional y nacional. Tampoco Giner de los Ríos cultivó un uso nacionalista del concepto de nación. En sus estudios sociológicos lo situaba en el mismo rango que la familia: el de las sociedades totales frente a las sociedades especiales, como las corporaciones profesionales o agrupaciones científicas (Giner, 2015: 336-342). A diferencia del carácter artificial de estas últimas, que mantienen unidos a sus miembros por los fines de su mutua cooperación, las primeras constituyen una «comunión total» que exige naturalmente la convivencia inmediata. Pero por encima de ambas, lo que define el modo de ser sujeto de cada uno de sus miembros es la organización jurídica.

El concepto de Estado es, pues, mucho más relevante que el de nación, para pensar la comunidad. Y ambos son subsumidos bajo el concepto de sociedad. Lo que, según Giner, singulariza a la nación con respecto a otras formas sociales, o estatales, incluida la familia, es la particular adhesión necesaria e involuntaria de sus miembros. Esta necesidad se sustenta en la noción de una sociedad total, entendida como un sujeto general en sentido distributivo (universal) y atributivo (histórico-cultural). Explicar cómo es posible la adhesión política y social — una cuestión abordada por Giner al tratar de justificar la subordinación de las penas jurídicas a la reinserción del delincuente- requiere ponerle rostro al sujeto de la sociedad total.

El autor de La soberanía política parece resolver la cuestión con la idea de «persona social», proyección colectiva de la subjetividad individual. Pero eso no hace más que esquivar el asunto, pues deja sin determinar las formas, espontáneas por necesarias, en las que aquella experimenta su adhesión el orden común. Nada dice de esas formas la convicción humboldtiana, suscrita por Giner, de que esa comunión es fundamental para la «promoción de los varios fines de la vida, en su unidad e integridad», toda vez que el institucionista no coloca como premisa, como sí hace Humboldt, a un individuo libre anterior al Estado (Giner, 2015: 147 nota) ${ }^{2}$. Tampoco ayuda, aunque sea un argumento incontestable para librar a Giner y sus discípulos del socorrido etiquetado nacionalista, sostener que

2. Esto es coherente con la posición combativamente anticontractualista que mantiene en toda su obra. 
la adhesión a la comunidad, del mismo modo que la unidad de esta, no es una cuestión «de procedencia»: no obedece a principios étnicos o de sangre, sino al espacio compartido, la convivencia en un mismo lugar. Se puede, en efecto, cambiar voluntariamente de lugar; pero nadie puede sustraerse a su necesaria integración en una comunidad nacional.

El problema es, entonces, interpretar qué quería decir Giner, como Posada y otros discípulos, al insistir en que aquella, sin ser una comunidad de descendencia, es una "comunidad de vida». Como en otras ocasiones, la vida se convierte en un concepto central, cuya invocación parece justificarse de suyo. Las razones biologicistas que puedan flanquearla, precisamente por el uso siempre matizado, si no desenfocado, que de ellas hace Giner, terminan pidiendo el principio. En realidad, las referencias a Spencer o Huxley en busca de argumentos que de inmediato eran corregidos, daban carta científica a la creencia, constante en la constelación krausista y bien asentada en el pensamiento conservador europeo del XIX ${ }^{3}$, en que para alcanzar alguna norma de orientación no debemos depender de impulsos subjetivos, sino recurrir a fuerzas e ideas que se han objetivado en nosotros y en nuestro pasado, como una forma interna que solo se puede percibir morfológicamente.

La afición a las grandes morfologías, exentas de ordenación sistemática en la fragmentaria recepción del darwinismo en España (Núñez, 1969: passim), terminó por someter la perspectiva biologicista a otra existencial, que confundía los procesos de la vida con los de la vivencia y, a la postre, el organicismo con la moralidad. En la obra de Giner, esta interpretación vivencial se expresa como latencia irreflexiva que produce, «por una génesis oscura», las relaciones de derecho. El vigor de la metáfora de lo latente, que Pidal explotó con éxito al explicar la continuidad histórica entre oralidad y literatura, reactualizó filológicamente el ideal protorromántico del poema que hace a una comunidad y la comunidad, o el pueblo, que hace al poema. Pero como argumento para identificar al sujeto de esa comunidad

3. Giner fue muy consciente de la dimensión conservadora de su organicismo: «Verdad es que si algún raro presentimiento de la naturaleza orgánica del Estado rompe a trechos la oscura niebla de nuestros partidos políticos, débese las más de las veces a hombres conservadores, sobre todo a los antiguos, no a los que conciben el derecho de Estado como la suma de los derechos de sus miembros o como el custodio que garantiza su ejercicio» (1973: 195). Para conocer la génesis alemana de este conservadurismo organicista son fundamentales los análisis sociológicos del pensamiento conservador publicados por Karl Mannheim en los años veinte y editados en español en los sesenta (Mannheim, 1963; 1966). 
el recurso a lo latente solo funciona en el estudio de las sociedades tradicionales sustentadas en la oralidad ${ }^{4}$.

El propio Giner había abierto este camino a los investigadores del Centro de Estudios Históricos al afirmar que, en la epopeya, «la sociedad es siempre su verdadero poeta»:

siendo el asunto de la Epopeya la sociedad y la realidad toda, requiere, a más de la unidad de ideas y la unidad de costumbres, la de su mutuo intrínseco encadenamiento: la unidad del fondo con la forma, del pensamiento con los hechos sensibles, de los principios con las instituciones; de suerte que todos estos elementos concuerden y se correspondan entre sí, concurriendo a mostrar el orden entero de la vida (1973: 62)

Esta percepción cultural de la epopeya desplaza el modelo biológico de la vida por ese otro existencial, del que nunca saldrá Américo Castro ${ }^{5}$. Pero una teoría de la epopeya, por mucho que en ella se vislumbren conceptos sociológicos o que pueda servir de ejemplo pedagógico para exponer la tenacidad del sentido común histórico, difícilmente podía aportar nada a la explicación de la persona social. Giner, sin embargo, siguió invocando la poética de los «poderes latentes» para entender el sujeto de las modernas relaciones de derecho. Y situó esa latencia en el plano del derecho consuetudinario, que, ya en Joaquín Costa, como luego en Pidal y antes en Eduardo de Hinojosa (bajo la influencia de la escuela historicista de Savigny $^{6}$ ) cortaba transversalmente el plano de la tradición literaria medieval. En esto, una vez más, Américo Castro será un aventajado epígono ${ }^{7}$.

4. Paul Zumthor, a finales del siglo xx y de manera bastante más fecunda que los discípulos españoles de Pidal, hizo suyo este concepto del estado latente como el propio de una «oralidad profunda» a la que define sociológicamente como «un conjunto complejo de conductas y modalidades discursivas comunes, que determinan un sistema de representaciones y una facultad de todos los miembros del cuerpo social de producir ciertos signos, de identificar y de interpretarlos de la misma manera»; una oralidad, en fin, que «hace referencia a la fuente primera de la autoridad que rige la práctica (a falta de ideología) de una sociedad» (Zumthor, 1989: 167-191).

5. Para la influencia de Giner y la Institución sobre Pidal y Américo Castro, cf. J. Portolés (1986).

6. En Pidal, a través de Hinojosa, influyen las ideas que Savigny expone, entre otros lugares, en Vom Beruf unserer Zeit für Gesetzgebung und Rechtwissenschaft, donde presenta al derecho como exigencia natural, producto vivo de la cultura de cada nación que germina intuitivamente en la «conciencia común del pueblo» y cristaliza en el Volksgeist. Entre la recepción catalana de estas teorías germanistas del derecho, destaca Martí de Eixalá, en cuya obra hay continuas referencias a la conciencia colectiva y el espíritu popular en Cataluña.

7. Esta cita de Castro resulta muy reveladora al respecto: «los cantares de gesta, tanto en España como en Francia, aparecen donde predomina el derecho consuetudinario y no 
Pero la pretensión de Giner no era medievalizar la historia moderna, sino fundamentar ontológicamente, bajo un ecléctico manto sociológico y al dictado del krausismo jurídico de Ahrens, una concepción del sujeto moderno y, por tanto, de las sociedades democráticas, alternativa al tradicionalismo católico y al individualismo liberal. De ahí sus esforzados intentos por atribuir al derecho consuetudinario, también en el Estado moderno, la capacidad para «establecer reglas generales de vida» y para encender «en los pueblos una fuente viva de inspiración superior, que se infunde luego en la mente de sus hombres de Estado» (Giner, 2015: 199). Y de ahí su interpretación de la opinión pública como la manifestación moderna de ese derecho consuetudinario.

El ejemplo de la Constitución inglesa es muy ilustrativo. En su crítica general al doctrinarismo político de su tiempo, desde el neoliberalismo al neocatolicismo, pasando por el socialismo, La política antigua y la política nueva encuentra en el constitucionalismo británico una expresión genuina de la relación entre la vida y la política o, lo que es lo mismo, entre la sociedad y el Estado. Su origen no residiría en la institucionalización parlamentaria ni en ninguna de las instituciones ni ordenaciones del derecho positivo inglés, sino en el protagonismo que en el orden constitucional cobra la continuidad de la costumbre, expresión inmediata de soberanía y, por tanto, de la «política real y verdadera» a la que aspirarían Giner y los juristas iluminados por Krause. Por el contrario, todo el doctrinarismo político francés, que desde Montesquieu quiso imitar literalmente la Constitución británica e incluso el doctrinarismo empirista inglés, que Giner considera vicario de aquel, muestra su incapacidad absoluta para entender la naturaleza de una constitución abierta siempre a los «progresos de la vida».

En esto Giner está muy próximo a las tesis de Azcárate desarrolladas en La Constitución inglesa y la política del Continente de 1878. Y no dista mucho de las tesis conservadoras que ya expusiera en Francia De Maistre, al ponderar la Constitución inglesa como argumento para despreciar las racionalistas revoluciones de Norteamérica y Francia; o del hegeliano

el tradicional de Roma. La costumbre es a la ley lo que la inmanencia del existir a la trascendencia de la norma sobrepuesta a ese existir... Las instituciones de tradición germánica — venganza y prenda privadas - contribuyen a llenar y fortalecer la forma de la vida castellana... En perfecta congruencia con ellas aparecen los personajes épicos de carne y hueso... La lengua hablada consuetudinariamente saltó sobre el latín de los clérigos, como la costumbre jurídica sobre la ley escrita... lo mismo que Castilla se rebeló contra la tutela política de León, una monarquía regida por Santiago y San Isidoro sin enlace con los proyectos de vida castellanos» (Castro, 1996: 229-230). 
Adam Müller, quien también sostuvo la imposibilidad de trasplantar el modelo consuetudinario británico al continente (Müller, 1935). «Se copian las leyes, no la vida», sentenciaba Giner (2015: 144), soslayando de nuevo la cuestión del sujeto de esa vida o más bien convirtiendo a esta en el sujeto.

Fuera del excepcional ejemplo de la Constitución inglesa, solo en la opinión pública encontró Giner una cristalización real de lo que consideraba esencia de la ley consuetudinaria: «el presentimiento de la unión y esencial comunión de todos los ciudadanos en el poder del Estado» (2015: 147), y un motor para articular las ideas políticas de una sociedad «en medio del inextricable laberinto en cuyo fondo germinan secretamente». De esta forma, despojaba a la opinión pública de su sentido sociológico y de su ropaje liberal para convertirla en una fuente de soberanía, muy por encima del «despotismo social» de las mayorías. En los términos aprendidos en los Principios de política de Röder, la realidad profunda de la opinión pública, entendida como realidad orgánica y no como el producto de la discusión pública, era la prueba manifiesta de la permanente subordinación de la ley a la costumbre. Cuando, en 1896, Giner vuelve al tema de la opinión pública, reitera su definición organicista, síntoma y a la vez factor de la «comunión de sentido» entre instituciones, autoridad y sociedad, favorecida por el «contagio de las masas»:

no es una suma, ni siquiera una resultante mecánica de fuerzas rígidas aisladas, sino el producto orgánico de las acciones y reacciones mutuas entre las diversas unidades sociales, que se penetran recíprocamente en sus estados de conciencia (2015: 327).

Lejos de la interpretación ilustrada como el espacio genuino de la crítica y la publicidad política — un espacio, por otra parte, casi inexistente en la sociedad española-, la opinión pública es, desde la perspectiva organicista de Giner, una morfología inmanente en la que, de modo análogo a la «poesía ingenua, popular y anónima» (Giner, 2015: 356), coexisten las formas «espontánea y reflexiva» de «todas las esferas del espíritu social» mostrando la soldadura orgánica de sus «fuerzas moleculares». El latente sujeto colectivo de esa opinión, como el sujeto del derecho, se intuye en términos de una conciencia inconsciente, en parte "pensamiento difuso de la sociedad» (359), en parte, una vez más, «sentido común histórico».

Paradójicamente, la «compenetración irreflexiva de todas las actividades sociales» dentro de ese sujeto colectivo (y, por tanto, dentro del Estado) requiere de los individuos que integran la sociedad — «órganos 
involuntarios de ella» (199)— una conciencia apolítica o, más bien, impolítica. Esta exigencia sería la lección práctica que puede extraerse del sometimiento de la filosofía política a la metafísica del derecho, y la condición antropológica necesaria para que una sociedad esté a la altura de sus «leyes desconocidas u olvidadas».

\section{Contra las «extravagancias del individualismo»: metafísica, política y policía}

Publicada entre el Sexenio Democrático y la Restauración, La política antigua y la política nueva suscitó reacciones encontradas. La crítica de Joaquín Costa fue elogiosa y prolija; la más lacónica de Manuel de la Revilla resultó, al menos para Costa, irreverente, sobre todo por reprochar la insignificancia del ensayo para la práctica política. Los argumentos del reproche apuntan a las irregulares relaciones de Giner con el trasfondo intelectual de su tiempo; estrechas y fructíferas con el krausismo, el positivismo e incluso con el marxismo; superficiales o inexistentes con el neokantismo y en general el criticismo. A pesar de que -o precisamente por eso- - Giner fuera una referencia en sus obras, Revilla lamentaba las «vagas síntesis armónicas» que desplegaba en sus escritos jurídico-políticos, y su reiteración de «vagos principios abstractos deducidos de una metafísica nebulosa», cuyos frutos prácticos no daban más que en «deplorables equivocaciones» (Giner, 2015: 417-419, 465-466). Estas equivocaciones que, según Revilla, Giner compartía con el krausismo y con el pensamiento conservador en general, preocupaban a quienes esperaban de la filosofía una orientación crítica del juicio político.

Revilla había encontrado el sujeto de ese juicio en el trascendental kantiano traído desde Heidelberg a España por José del Perojo, cuyos textos, pronto indexados por la censura eclesiástica, sufrieron, como todo el primer neokantismo español, el silencio de quienes no siguieron los rituales del debate entre krausistas y neocatólicos ni participaron en su prolongado reparto del espacio filosófico español (Villacañas, 2006: 75-98). En ese escenario, la filosofía de Kant era subsumida bajo un positivismo sofisticado, al servicio de las síntesis imaginadas por los krausistas entre especulación metafísica y espíritu científico naturalista. Esa imaginación era irreconciliable con la separación kantiana y luego weberiana entre las esferas del conocimiento y de la vida. Muy lejos de ella, el organicismo de Salmerón proclamaba la síntesis definitiva entre el monismo científico de Haeckel y el especulativo de Krause. Giner fue lector de Haeckel y de Kant. Pero, a pesar de su admiración, leía al autor 
de la Crítica de la razón con un recelo similar al que le despertaba toda la tradición del individualismo moderno en el que de manera confusa lo incluía. El sujeto social, como el sujeto del derecho, como el sujeto de la educación que inspiró a la Institución Libre de Enseñanza, no era precisamente el individuo moderno en ninguna de sus manifestaciones, por dispares que fueran: kantiana, rousseauniana o liberal a lo Stuart Mill (Giner, 2015: 179). De un modo u otro, todos eran síntoma de la «extravagancia» atomista del individualismo, fuente de un «sinnúmero de errores» (198). Las síntesis metafísicas que Revilla encontraba en su respetado Giner aspiraban a conjurar los peligros del atomismo, que eran también los de la modernidad.

Giner no ocultaba sus paradójicas afinidades electivas con los pensadores socialistas, además de los conservadores, quienes por vías diferentes concebían la sociedad «no como un agregado de sujetos sumados, sino como un todo real y sustantivo», y reconocían

la esencial y permanente inherencia en su personalidad superior de diversas fuerzas, esferas, órdenes que la constituyen por naturaleza, no por la mera arbitrariedad de los hombres, que pudiera muy bien destruir todos esos elementos; su proclamación de la necesidad de modelar la organización social según principios éticos e interiores, fundados en el destino humano (Giner, 2015: 155).

Giner reformuló la síntesis metafísica de sus maestros hispanogermanos como la fórmula política con la que superar las limitaciones de, por un lado, la vía neocatólica, que, especialmente en la versión de Donoso, situaba en el gobierno del Estado el fundamento de soberanía (Giner, 2015: 120-121), y, por otro, la vía socialista, lastrada por el irracionalismo revolucionario y el error de buscar el espíritu interno de la sociedad en la «fuerza material» y no en la «vida misma en su unidad» (156). Esa superación no podía llevarse a cabo tampoco desde la doctrina de Kant (que, para mayor malentendido, Giner situaba en la misma constelación de Schelling, Hegel o Savigny) de la equivalencia entre derecho y libertad, incomprensible para una concepción vitalista del sujeto, en frontal oposición a la formal kantiana (185).

En esta constelación de categorías, a un tiempo antimodernas y antirreaccionarias, el concepto de acción, que muchos consideran medular en la obra de Giner, se refiere en primera instancia a la «constitución dinámica» de una realidad social sustantiva y a las interacciones de sus miembros. Solo de una manera oblicua, cuando no negativa, concierne a la praxis individual, a la acción racional orientada por la reflexión de los 
propios fines, o al problema de la decisión. La refutación de la ilusión individualista es el principal motor de una pasión por la sociología que termina siendo casi siempre una antropología metafísica próxima al Comte más místico, al que tradujo tempranamente. Desde esta perspectiva, el sujeto político solo es tal cuando deja a la política fuera de lo individual, o, dicho de otro modo, cuando se reconoce en el fondo esencial, «olvidado», de vida política que constituye el ser común desplegado en la historia y en el Estado, y se manifiesta en todas las formas de la vida pública y privada, como la familia. Bajo la cosmovisión de una política total, lo político concreto se reduce a objeto de un artificioso doctrinarismo y se convierte en mera policía.

Traduciendo la anglosajona policy, Giner llama «policía» a una «forma limitada de la política», que consiste en la mera administración por parte de instituciones como los tribunales, el ejército y «otros agentes de inferior consideración $»^{8}$. Su concepción del término se vuelve más clara y peliaguda cuando lo utiliza en polémica con Calixto Bernal, para descalificar su definición de la política en Teoría de la autoridad como «la ciencia que enseña la mejor manera de conducir a los hombres en el respeto mutuo de sus derechos» (Giner, 2015: 415). Giner aprecia en esta definición una simple tarea de administración coercitiva, por encima de la cual la «verdadera idea» de la política se eleva a «racional armonía de las relaciones proporcionadas entre seres recíprocamente libres y unitariamente encaminados al bien por el Derecho». No extraña la sumisión de la política, esta política, a su noción metafísica del derecho social — «un orden de cosas racional, eterno, inmutable» (Giner, 1973: 191) cuando el fin de ambos y, por supuesto, el del Estado, es «coadyuvar a la realización de nuestro destino».

La libertad que, siguiendo a Humboldt, Giner ve amenazada por la «funesta inmixtión» del Estado, no es la del sujeto de la decisión y de los conflictos políticos, sino la del «desenvolvimiento natural de las facultades». La localización del verdadero sujeto de la política, es decir, el sustrato común de estas facultades ciegas, no puede salir más que de la idea de organismo o de «espíritu social». Pero esta idea, que se corresponde con «la inmanencia de la soberanía en el todo social» (Giner, 1973: 194), entraña, paradójicamente, la negación del individuo político.

8. La filosofía política contemporánea ha utilizado también la dualidad policía-política para sostener tesis completamente contrarias a las de Giner sobre la naturaleza de lo político (Rancière, 2006: passim). 
El apoliticismo que subyace a las tesis políticas de Giner no puede confundirse con el pensamiento impolítico ${ }^{9}$ moderno, del mismo modo que su exposición del biologicismo político nada tiene que ver, a pesar de los esfuerzos de algunos exégetas, con la crítica de las prácticas de poder concebidas bajo el término de «biopolítica» ${ }^{10}$. Más tiene que ver con la «vitalidad apolítica de los españoles» que, una vez más, Américo Castro argumentó en la posguerra civil, para justificar el «realismo» y el «integralismo» del sujeto hispánico (Castro, 1996: 336). Para entonces la política, en cualquiera de sus concepciones, ya había perdido toda posibilidad de definir una supuesta realidad común de los españoles, que era confiada definitivamente a las fuerzas ocultas de la tradición literaria. Y en eso, ya lo hemos dicho, los epígonos siguieron teniendo muy presente al Giner convencido de que, por su capacidad para revelar la «coexistencia de las formas espontánea y reflexiva», la poesía popular (denominada, a lo Schiller, «ingenua») es «expresión inmediata del alma de las naciones».

\section{El sujeto sublime de la educación}

«Cuando el pueblo español esté a la altura de su paisaje...»: esta sentencia inacabada y acaso inacabable, que Américo Castro decía haber oído en boca de Giner (Castro, 1973: 90) y que aún evocan algunos historiadores (García Cárcel, 2011: 439), expresa la esperanzada resignación del maestro ante las dificultades para realizar en su propio país el ideal de

9. Uso este término en el sentido en que lo hace la filosofía política contemporánea; $c f$. Alfonso Galindo Hervás, Pensamiento impolítico contemporáneo, Madrid, Séquitur, 2015.

10. Me refiero en particular al texto de José Manuel Vázquez-Romero «El concepto de estado individual krausista y su relevancia biopolítica» (2009). Cuando se insiste en releer en el siglo XIX a Giner de los Ríos bajo el lema de la actualidad de un pensador krausista, es comprensible que se actualice también la afición hispano-krausista por sintetizar especulativamente doctrinas importadas. La neutralización de los antagonismos políticos en la obra de Giner y el krausismo, bajo la normalización del hombre como sujeto, parece encontrar lugares de coincidencia en la obra de algunos filósofos contemporáneos - todos ellos reconocidos bajo la amplia etiqueta de impolíticos-. La reproducción de referencias cruzadas entre las tesis de Giner, Calderón, Posada o Costa, por un lado, y de los filósofos Agamben, Esposito o Foucault por otro, a cuenta del problema de la representación y de las relaciones entre poder y sujeto, confunde la conceptualización de los términos en unos y en otros. Lo mismo ocurre con la identificación entre la biología organicista de la política y las prácticas de la biopolítica (Vázquez-Romero, 2009: 51 ss.). Es evidente que cuando Giner describía al Estado en los términos del biologicismo de cuño darwinista, o incluso cuando mencionaba ocasionalmente a la Biología política y la Política médica como una de las muchas funciones de los órganos y poderes del Estado (Giner, 2015: 203), no se refería a las prácticas de poder-saber como agentes de transformación y control de los individuos. 
una educación universal. Pero también dice mucho de la naturaleza a un tiempo espectral y sublime del sujeto al que ese ideal iba destinado. Espectral, por su presencia inasible, y por la amplitud, larga hasta el etcétera, de sus apariciones, que, al modo del «espíritu social», comparecen bajo un continuo de categorías intercambiables; sea como

sustancia dada, al modo como se suele concebir el alma del individuo; sea como un producto derivado a posteriori de las mutuas relaciones entre estos y consolidado en obras [...]; sea como un sujeto hipotético, un quid, que suponemos sirve de base a esas manifestaciones; o como lo común en los mismos individuos; o como una energía actual, que reduce a unidad la pluralidad de estos, etc., etc. (Giner, 2015: 305).

Y sublime porque, como sujeto general, ese quid, «el pueblo español», y en particular sus jóvenes educandos, habría de saber medirse con su colosal paisaje: la manifestación de una desbordante naturaleza, que, como todo kantiano sabía, más allá de su distante espectáculo no se muestra disponible al orden de nuestra subjetividad, salvo que esta se disuelva confundiéndose con aquella ${ }^{11}$. El ideal pedagógico de Giner se podría entonces reformular como una empresa estética fundamental: educar a la persona individual y social para convertirla en sujeto de lo sublime. Una tarea inseparable de otra políticamente no menos crucial: educar para lograr «una sociedad que esté a la altura de sus leyes olvidadas y desconocidas». La versión hispánica, en fin, de una educación de la Humanidad.

Sin duda, cientos de páginas dedicadas a la pedagogía por Giner y sus discípulos institucionistas obligan a matizar esta interpretación, inspirada en una sentencia ocasional. Sus extraordinarios métodos de enseñanza -hoy ignorados, al mismo tiempo que elogiados, por los administradores de la pedagogía-; su rechazo de las estrategias educativas tradicionales sostenidas en la desigualdad, o su infatigable batalla contra unos gobernantes enemigos de la formación de sus gobernados, convergen en la misión última de educar a la persona individual en libertad. Pero otras muchas páginas, precisamente aquellas que justifican sociológica y metafísicamente ese propósito y los métodos para conseguirlo, describen a esa persona por educar en los términos de una «cristalización» en la que han de confluir armónicamente naturaleza, sociedad e historia.

11. Américo Castro, al rememorar sus excursiones infantiles con Francisco Giner por la sierra de Guadarrama, afirma: «aprendimos a concebir el sin límite de las cosas» (Castro, 1975: 89). 
En esa confluencia, en esa totalidad dinámica y en esa noción podría decirse que sublime, por lo desbordante, del sujeto, residiría el germen, metafísico antes que político, de «la idea de un fin común y de una igual dignidad». El problema es cómo educar, cómo formar a una persona semejante. El único modelo pedagógico a la altura de la tarea era el platónico, que Giner defendió con entusiasmo ${ }^{12}$. Pero mientras el platonismo de la Academia salvaba la inconmensurabilidad entre los individuos geometrizando sus relaciones, el platonismo institucionista aspiraba a neutralizar los antagonismos de las subjetividades —amenazadas por la «idolatría de la nivelación y de las grandes masas» (Giner, 1973: 116)— disolviéndolas en esa persona orgánica que es la sociedad, a quien la ILE, «después de a Dios, todo lo debe» (Giner, 1973: 102).

Conciliar a Sócrates con Platón no es nada fácil, por mucho que el último se empeñara. Tampoco lo es conciliar una enseñanza que favorece el diálogo en «la intimidad entre maestro y discípulo» con una rigurosa educación integral, en la que la jerarquía entre ambos se viste de común vitalidad $^{13}$. La dificultad crece cuando la formación del individuo se entiende como «su diferenciación de lo que podríamos llamar la masa amorfa» (Giner, 2015: 353), despertándole, al mismo tiempo, la conciencia de su plena integración en ella. Pero, más aún que al educando, el problema de las relaciones con la «masa amorfa» concierne a la figura del educador, que se eleva por encima de los mayores obstáculos y las más hostiles condiciones ${ }^{14}$. Giner abordó la doble y contradictoria naturaleza del maestro (a un tiempo excepción y representación) en su estudio de la función social de la ciencia y del científico: el lugar de ambos en el organismo social y, por tanto, su relación con los saberes y los sujetos no científicos.

12. «Platón será el eterno modelo de toda enseñanza digna de tal nombre» (Giner, 1973: 90).

13. «Y entonces la cátedra es un taller y el maestro un guía en el trabajo; los discípulos, una familia; el vínculo exterior se convierte en ético e interno; la pequeña sociedad y la grande respiran un mismo ambiente; la vida circula por todas partes y la enseñanza gana en fecundidad, en solidez, en atractivo lo que pierde en pompa y en gallardas libreas» (Giner, 1973: 107). Y: «Maestro y discípulos, a despecho de los reglamentos, se juntan en medio de la sociedad, en un solo cuerpo y un alma, donde cada cual da su parte para el fin común; obra, por una parte, de la serenidad, de la reflexión y la experiencia, y, por otra, del brío y el empuje inicial de la idea y la honrada alegría de la vida» (137).

14. «Dadme al maestro y os abandono la organización, el local, los medios materiales, cuantos factores, en suma, contribuyen a auxiliar su función. Él se dará arte para suplir la insuficiencia o los vicios de cada uno de ellos» (Giner, 1973:114). 
En el fondo, este era también el problema de las élites: el de su formación y su influencia en el cambio social y político. Giner coincidía con quienes explicaban la «génesis de los grandes hombres» según «un proceso gradual, análogo al de la diferenciación de las funciones sociales, que Spencer resume con exactitud» (Giner, 2015: 357). El spencerismo era un buen antídoto biológico contra la tentación de imaginar un individuo único, como el héroe de Carlyle, segregado de ese hombre masa que décadas más tarde preocuparía tanto a Ortega. Pero ni siquiera Spencer fue capaz, según Giner, de percibir cómo «la raíz de este orden de actividad», de la ciencia, de la obra del sabio, y del saber de la minoría, «arranca del fondo general de la vida y del pensamiento comunes» (Giner, 2015: 361). Sus críticas a Tarde, Le Bon y, sobre todo, Renan censuran el miedo a la creación de una «medianía universal» (tan temida también por Ortega) por «la extensión de la cultura, al producir cierta nivelación de los espíritus».

El maestro Giner, volcado en la ingente tarea de sacar a su país de la ignorancia, conjuraba estos temores argumentando que la «masa de ideas fragmentaria, incoherente», se acababa incorporando "como esferas concéntricas» a las investigaciones científicas y en general al saber reflexivo (375). El entrecruzamiento entre lo reflexivo y lo espontáneo, lo consciente y lo inconsciente, lo individual y lo colectivo, configura entre maestros y educandos un espacio de relaciones semejante al que determina los vínculos entre el genio literario y la poesía anónima, o entre el legislador y el fondo común de leyes olvidadas. Lo que singulariza los efectos del magisterio, como los de la ciencia, es el enriquecimiento cuantitativo y cualitativo del patrimonio material y espiritual de la sociedad de la que surge. Giner no puede salir de la contradicción inevitable entre la «minoría directora» y el «cuerpo social», sino apelando a una imprecisa «vuelta de la educación por la realidad a la concepción orgánica española» (Giner, 1973: 137).

El cometido de su Institución fue roturar y cultivar la realidad de un país cuya incultura, hostilidad, inexperiencia e ingratitud, encarnadas en sus élites políticas, Giner describió con aspereza. A pesar de sus diferencias con Tarde, estaba convencido del poder educativo de las corrientes de la imitación. Pero no pudo explicar cómo su «ministerio educador» podía emerger gradualmente de «las profundidades del espíritu nacional». No deja de sorprender la tenacidad con que mantuvo la existencia de ese espíritu, reconvertido en un sujeto social y estético: un sentido común hispánico cuya presencia, como una teología negativa, parece cobrar fuerza cuanto más evidente es su ausencia. La suya no fue una sociología 
del conocimiento. Más que en los argumentos sociológicos, la clave de su confianza en la realización institucional de sus ideales educativos se encuentra en su manera de entender las relaciones entre soberanía y representación, fundadas en una metafísica del Derecho: a la «soberanía inmanente en el cuerpo social» le corresponde el valor representativo de sus corporaciones, y el de «una minoría directora, compuesta de hombres de diverso tipo, según su individualidad, pero [en la] que todos colaboran al movimiento de un modo semejante» (2015: 345 nota).

La resistencia de Giner a ser considerado parte de esa «minoría» intelectual, que sus epígonos interpretan como rasgo de un sobrio ethos hispánico, no tiene que ver tanto con una apología del principio de acción frente al diletantismo del hombre teórico, como con su fidelidad a esa raíz colectiva de vida y pensamiento. Fidelidad a una fe inamovible en la existencia de un sujeto oculto, cuya soberanía inmanente habría de manifestarse en la actitud de los individuos ante la naturaleza y el arte: una actitud forjada, como el resto de energías vitales, en un amplio programa de educación, lento y duradero.

A la sombra de ese sujeto, el ascetismo que le hacía renegar de su relevancia pública lo acercó a la figura de santo, humilde y digno, que describiera Castro ${ }^{15}$, además de Antonio Machado o Manuel Cossío. Y le inviste de un excepcional poder representativo del espíritu hispánico: un poder que Machado calificó, en un telúrico obituario, de magnético e invisible ${ }^{16}$. Probablemente esa invisibilidad fuera el mejor modo, si no el único, de ejercer el papel de educador y, a su pesar, de intelectual y clerc de una nación y una opinión pública aún más invisibles.

\section{Bibliografía citada}

CAPELlán, Gonzalo, «Giner de los Ríos: un viaje crítico por la historia del pensamiento político y social», en F. Giner de los Ríos, El pensamiento en acción (Textos), ed. G. Capellán, cit. infra, pp. 9-66.

CASTRO, Américo, Ensayo sobre historiología. Analogías y diferencias entre hispanos y musulmanes, New York, Feger, 1950.

15. «Tras la humilde envoltura se percibía al señor de la estirpe distinguidísima y, ante todo, la prodigiosa dignidad de su espíritu. Pudo serlo todo, brillar como gobernante o en la vida social más alta. Mas no aspiró a ninguna popularidad, y ante él se recataba la lisonja trivial» (Castro, 1975: 88).

16. «Toda la España viva, joven y fecunda acabó por agruparse en torno al imán invisible de aquel alma tan fuerte y tan pura» (Machado, 1915). 
— [1957] «De grata recordación (Juan Valera y Alberto Jiménez», en Españoles al margen, cit. infra, pp. 143-165.

- [1973] Españoles al margen, Gijón, Júcar, 1975.

- [1937] «Francisco Giner», en Españoles al margen, cit. supra, pp. 87-96.

- [1941] «The meaning of the Spanish civilization», en José Rubia Barcia (ed.), Américo Castro and the meaning of Spanish civilization, Berkeley / London, University of California Press, 1976, pp. 23-40.

- [1948], España en su historia. Cristianos, moros y judíos, Madrid, Crítica, 1996.

GARCÍA CÁRCEL, Ricardo, La herencia del pasado. Las memorias históricas de España, Barcelona, Galaxia Gutenberg, 2011.

Giner DE LOS Ríos, Francisco, Ensayos, ed. de Juan López-Morillas, Madrid, Alianza Editorial, 1973.

- El pensamiento en acción (Textos), ed. Gonzalo Capellán, Madrid, Biblioteca Nueva, 2015.

LóPeZ-Morillas, Juan, Racionalismo pragmático. El pensamiento de Francisco Giner de los Ríos, Madrid, Alianza, 1988.

MACHADO, Antonio, «Don Francisco Giner de los Ríos», Idea Nueva (Baeza), 23 de febrero de 1915; Boletín de la Institución Libre de la Enseñanza, 664 (1915).

MANnheIm, Karl, Ensayos sobre sociología y psicología social, México, FCE, 1963.

- [1929], Ideología y utopía, Madrid, Aguilar, 1966.

MenÉndez Pelayo, Marcelino [1882], Historia de los heterodoxos españoles, II, Madrid, CSIC, 1992.

MENÉNDEZ PIDAL, Ramón, «El estado latente en la vida tradicional», Revista de Occidente, segunda época, 2 (1963), pp. 129-152.

MÜLLER, Adam [1809], Elementos de teoría política, Madrid, Revista de Occidente, 1935.

NÚÑEZ, Diego [1975], La mentalidad positiva en España, Madrid, Universidad Autónoma de Madrid, 1987.

- (ed.), El darwinismo en España, Madrid, Castalia, 1969.

PORTOLÉs, José, Medio siglo de filología española (1896-1952). Positivismo e idealismo, Madrid, Cátedra, 1986.

RANCIÈre, Jacques [1998], Política, policía y democracia, Santiago de Chile, LOM, 2006.

REVILLA DE LA, Manuel, reseñas a «La política antigua y la política nueva», Revista Contemporánea, 1, 1 (1875), pp. 124-125; y 2, 4 (1876), p. 530; cit. en F. Giner de los Ríos, El pensamiento en acción, cit. supra, apéndice II ( «Reseña a los Estudios jurídicos y políticos de Giner»), pp. 417-419 y 465-466.

VÁzQUeZ-Romero, José Manuel, «Dos en uno. El concepto de Estado individual krausista y su relevancia biopolítica», en J. M. Vázquez-Romero (ed.), Francisco Giner de los Ríos. Actualidad de un pensador krausista, Madrid, Marcial Pons, 2009, pp. 27-81. 
Villacañas Berlanga, José Luis, Kant en España. El neokantismo en el siglo XIX, Madrid, Vérbum, 2006.

ZumThor, P., La letra y la voz. De la literatura medieval, Madrid, Cátedra, 1989.

Fecha de recepción: 1-11-2015

Fecha de aceptación: 28-11-2015 


\title{
LA IDEA DE CRÍTICA DEL ARTE EN EL PENSAMIENTO ESTÉTICO DE FRANCISCO GINER DE LOS RÍOS ${ }^{1}$
}

\author{
RICARDO PINILLA BURGOS \\ Universidad Pontificia Comillas
}

\section{Resumen}

En sus lecciones estéticas, aparecidas en el BILE en 1877-1878, Giner hace una defensa de la Estética como disciplina autónoma, su valor práctico, y su relación con las artes y la literatura, respondiendo desde el horizonte fundamental de su concepción krausista a cuestiones y polémicas unidas a la Estética en el contexto cultural y político de su tiempo. A partir de un rico pensamiento estético y una amplia concepción del arte como actividad esencial humana, Giner elabora en esas lecciones, entre otras cuestiones, una idea de Crítica del Arte, en íntima vinculación con la producción de una obra singular y con la interpretación de los principios generales, que permitirá una reconsideración profunda de la actividad del crítico, que Giner ejercerá de modo brillante en distintos ámbitos, y que se abre a una importante reflexión sobre la peculiaridad y relevancia vital del juicio estético.

Palabras clave: Estética; Crítica; Principios; juicio; producción artística.

\begin{abstract}
In his Aesthetics-Lectures (BILE 1877-1878), Giner makes the case for Aesthetics as an independent subject, with a practical value of its own and its particular relationship to the Arts and Literature from Krause's thought perspective. In his work, he also answers several questions and controversies associated with Asthetics in his cultural and political context. From a starting point of rich aesthetical thought and a broad concept of art, Giner also presents in these lectures, among other topics, an idea of Criticism, in close relation with the production of a singular work of art and also with
\end{abstract}

1. Este artículo se ha realizado en el marco del proyecto de investigación FFI2011-23682: «Fundamentos y desarrollo de la idea krausista de Europa: universalismo, internacionalismo, educación y cultura».

Anales, 27 (2015), pp. 81-106

DOI: 10.14198/ALEUA.2015.27.05 
the interpretation of general principles. Giner has an interesting body of work on several arts that lead him to a conception of Criticism closely connected to an important reflection about the special meaning and relevance of the aesthetic judgment in life.

Keywords: Aesthetics; Criticism; Princips; judgment; artistic production.

\section{Dos proyectos krausianos en el universo gineriano: Estética y Ciencia del Arte}

Ya ha pasado una centuria desde la muerte de Francisco Giner de los Ríos, y su figura no deja de agrandarse y, aún más, de enriquecerse y matizarse conforme se estudia su obra. Más allá de loas y elogios, o de recordar las estelas vibrantes de su magisterio, hoy día el mejor homenaje que podemos hacer a Giner es leerlo y releerlo y ponerlo a hablar con nuestra actualidad y nuestro horizonte. Es seguro que, en ese ejercicio, la letra de don Francisco no palidecerá. Antes bien, veremos cómo revive en ella el espíritu inquieto e incansable de quien buscó con ahínco la verdad y vivió de modo muy íntimo la educación como una tarea inaplazable y siempre abierta.

Entre los muchos aspectos y contribuciones importantes que ofrece su pensamiento, el tema de la estética y las artes es sin lugar a dudas uno de los pilares que consolidaron su personalidad como maestro y verdadero forjador de cultura y de horizontes educativos para muchas generaciones. De su actividad en este campo quedan traducciones (sobre todo su crucial labor de traductor y receptor de la Estética de Krause), y su magisterio e influencia en multitud de realizaciones de todo orden relacionadas con el mundo del arte, la música, la literatura, el patrimonio artístico o las artes industriales. Pero también y sobre todo para nuestra actual reflexión, como reflejo de una meditación viva, nos llegan sus agudos escritos que plantean un pensamiento original, digno desarrollo de los postulados krausistas, y abiertos a muchos problemas estéticos y culturales de su tiempo ${ }^{2}$.

No obstante, sería algo limitado tasar la aportación de Giner a la Estética ciñéndonos a su concepción de esta disciplina. Trataré de explicarme. Diferente aunque superpuesta a la idea de una «ciencia estética», en Giner hay elementos muy importantes para una amplia «ciencia del arte» como teoría general de la acción humana y la valoración de medios y fines en

2. Estos aspectos los he desarrollado en varios trabajos: cf. 2005, 2009a, 2010, 2012. Sobre la actividad musical de Giner y la Institución Libre de Enseñanza, son ya imprescindibles los estudios de Leticia Sánchez de Andrés (2009a, 2009b). 
la realización de sus obras. En la obra de Krause hay elementos muy interesantes para ver estos dos proyectos, que, lejos de ser incompatibles, se complementan e interseccionan. En Giner se puede decir que conviven ambos sin por ello necesitar confundirse, aunque sí se relacionan en puntos muy importantes, manteniendo a su vez una sólida independencia.

En la filosofía de Krause la idea de arte pronto fue relevante como un ideal de la actividad humana, y es verdad que la concreción de esa idea de modo paradigmático como arte bello no es algo ausente en su obra, pero Krause, de una manera ya un tanto anacrónica o a contracorriente en su época, conservó en sus escritos la acepción general de arte (Kunst) como algo más amplio que el dominio del arte bello. A su vez, la idea de belleza, verdadero epicentro de la Estética krausiana, entendida como una filosofía de lo bello y del arte bello, es central en su pensamiento metafísico y acerca de lo real, y una característica esencial del Ser supremo; descubriendo en lo bello la señal de semejanza de cada ser con Dios dentro de su finitud, a la vez que concentrando en sí todo el cuadro de categorías krausianas acerca de las cosas y su realidad (unidad, diversidad, armonía) en su carácter orgánico, como una unidad cuyo contenido son diversas partes compensadas y contrastadas entre sí.

De otra parte, el arte en su más amplio sentido formó para Krause un binomio fundamental junto a la ciencia como actividad fundamental de la Humanidad. El modo en el que la íntima condición de lo humano podría realizarse consiste en ir descubriendo y conociendo la verdad a través de la ciencia, realizando lo esencial en el tiempo en los diversos ámbitos de la vida, a través de las distintas artes, no solo las bellas o libres. De ahí que la idea de arte se resuelva en Krause como la esfera de la acción y del poder hacer (können), como complemento co-esencial de la acción humana junto a la capacidad de conocer (kennen) de la ciencia (Krause, 1829: 553) ${ }^{3}$.

En el célebre artículo de Giner «El Arte y las artes», aparecido en 1871, se explora a partir de este último planteamiento la necesidad de una profundización en este concepto y se llega a un resultado contundente, que nos permite hablar de una teoría de la acción humana en tanto que acción artística en su sentido amplio. Hoy quizá utilizaríamos otras palabras como técnica, o acaso acción y actividad, pero el uso de este preciso término y el trabajo gineriano no nos permite tan fácilmente hacer esta traslación. Recordamos un conocido pasaje de ese artículo en este sentido:

3. Para una exposición del amplio pensamiento estético de Krause, cf. Pinilla, 2002, 2013.

Anales, 27 (2015), pp. 81-106 
[...] obra artísticamente quien, en la ejecución de una empresa cualquiera, procede de tal modo que toda su acción, recogida en sí misma y atenta cuidadosamente a su objeto, sin distraerse de él un punto, hace converger y servir para este con perseverancia y delicado tacto cuantos medios se requieren, hasta lograr que el resultado corresponda a su idea (Giner, 1919: 2).

Resuenan en esta definición lo mejor de la idea clásica aristotélica de tecné y la acepción krausiana del arte como la actividad originaria humana que realiza lo esencial y conforme a Ser en el tiempo (Krause, 1882: 184). Este pasaje retrata muy bien un aspecto del modo de Giner de acometer cualquier empresa: esa concentración o recogimiento cuidadoso, esa entrega al objeto del quehacer. Ahora bien, a pesar de propiciar esta reflexión una posible interpretación de la relevancia del arte para Giner en un campo ya extra-estético, cabe decir que tanto el modelo de la formación del gusto y del espíritu artístico bello, como la educación de la razón y el discernimiento para formular juicios críticos válidos en torno a las obras de arte bello (lo que se venía a denominar crítica en un sentido amplio en el mundo del arte), siempre fueron para don Francisco guías muy presentes en el contexto de su ideal formativo. Tan erróneo sería por lo tanto no distinguir los dos proyectos mencionados, como divorciarlos o meramente yuxtaponerlos circunstancialmente. En esa diferencia y relación reside posiblemente uno de los elementos más genuinos de todo el universo gineriano.

Pensar lo bello y el fenómeno estético en todas las esferas de la vida, y a la vez asumir de modo responsable y reflexivo la actividad humana como un arte general del vivir, son en definitiva esos dos horizontes bien nítidos y diferentes, pero que no dejan de fecundarse en el pensamiento krausiano y por ende gineriano. Y es desde esos horizontes desde donde cabe entender la profundidad y alcance de las reflexiones de Giner en torno a la tarea del crítico de arte y, en general, de la relación de nuestro pensamiento y juicio ante la obra humana en su diversidad, pero en esa vocación tan especial a la que es llamado el artista bello en la factura de su obra y en la expresión de esa poesía interior que, como una profunda voz y guía, le lleva a emprender el camino de la creación libre en busca de la belleza.

\section{Ubicación sistemática de la crítica del arte en las lecciones estéticas del Boletín de la Institución Libre de Enseñanza}

Entre finales de 1877 y 1878 sabemos que Giner publicaba en el Boletín de la Institución Libre de Enseñanza unas lecciones tituladas «Estética con especial aplicación a las bellas artes». En el título ya llama la atención el 
énfasis en las bellas artes, que de equipararse la Estética a la Teoría del arte parecería innecesario. Giner pretende de un lado afianzar el carácter legítimo de esta disciplina, y de otro apelar a la aplicación y valor práctico de esta en las bellas artes.

Estas ocho lecciones se presentan en ese tono modesto y funcional que encontramos en otros escritos de Giner. De hecho aparecen publicadas en el apartado del BILE titulado «Resúmenes de enseñanzas», donde se publican otros resúmenes de diversos cursos impartidos por los profesores de la Institución Libre de Enseñanza. Así, comienza don Francisco indicando que «[e]sta enseñanza tiene un carácter elemental», por lo que no pretende ser una «investigación radical», sino «una exposición de los resultados que hoy de común acuerdo aceptan en esta esfera las más diversas escuelas y partidos» (Giner, 1877: 77). En efecto, Giner nos trazará un completo estado de la cuestión y aludirá a numerosos autores, pero en absoluto son estas lecciones mero eco de opiniones «de la cultura actual». Disintiendo así de la intención manifestada por el propio Giner, creemos que, dentro de su pretensión sumaria, contienen estas lecciones algunos aspectos fundamentales de un pensamiento estético y sobre el arte muy original, con un amplio marco filosófico, a la vez que, eso sí, en respuesta directa a cuestiones que la ciencia estética planteaba en su época.

Los títulos de las lecciones desvelan un interés por dejar clara la legitimidad científica de esta ciencia (lecciones $1 .^{a}, 2 .^{a}$ y especialmente $5 .^{a}$ ), así como lo que Giner llama su valor práctico $\left(3 .^{a}, 4 .^{a}\right)$ y su relación con las teorías de las artes particulares, de modo especial con la Teoría de la Literatura $\left(6 .^{a}, 7 .^{a}\right)$; pero también con la Ciencia del Arte como tal $\left(8 .^{a}\right)$, asunto con el que concluye el ciclo y denota la nitidez con la que Giner concebía los dos proyectos o ciencias distintas: la Estética y la Ciencia del Arte, lo que no excluía por supuesto que ambas se relacionasen fecundamente en la teoría del arte estético, dado que puede haber un arte que no tenga como fin la belleza. Giner valora en esto la aportación de Krause desde su distinción de arte bello, arte útil y arte bello-útil, admitiendo que es una clasificación «de tal importancia que es la dominante», frente a otras como las de artes bellas frente a artes meramente agradables o recreativas (Kant, Jungmann), o artes independientes y dependientes (Vischer). Giner no deja de ver problemas en esta división, como es el hecho de clasificar no tanto cada obra, como él propondría, sino las artes como tales. Él entiende que todo arte es susceptible de estar encaminado a la belleza y también a la utilidad. De otro lado, se pregunta si aun en las artes estéticas, aunque el fin sea la belleza pura, en tanto que artes y por lo tanto como organización 
y manejo de unos medios y unas destrezas para un fin, no hay siempre una utilidad en un sentido profundo. Con todo, lo que valora de la clasificación de Krause es que con ella, y acaso con la indagación krausiana de la idea de arte y su amplia concepción, se nos ofrece «la primera [clasificación del arte], tal vez, en que se ha intentado abrazar la esfera total artística» (Giner, 1878: 27).

La cuestión de la legitimidad de la Estética y de su valor práctico y aplicación al mundo del arte, como nos desvelan algunos trabajos sobre la introducción de la Estética en España (Orden, 2001; Roviró, 2011), sabemos que no estaba exenta en ese momento de implicaciones indirectamente políticas, pues la Estética como disciplina autónoma respecto a la Literatura y la Retórica, y como una materia dentro de los estudios de Filosofía, se convertiría en seña de identidad del pensamiento liberal y progresista. En efecto, la nueva disciplina de la Estética, nacida en Alemania a mitad del siglo XVIII, se introduciría en España inicialmente dentro de los estudios literarios como una materia auxiliar. El ubicarla autónomamente y reclamando su base filosófica, operación propiciada especialmente por Sanz del Río y los krausistas (Orden, 2001: 262 ss.), otorgaba al análisis del hecho literario y artístico en general una libertad y un amplio horizonte, a la vez que completaba el campo del pensamiento y la formación, asumiendo la dimensión estética y la actividad artística como algo primordial y sustantivo dentro de la cultura. Cuando revisamos cómo esta materia fue incluida y suprimida en los planes de estudio de Filosofía en varias ocasiones según los cambios de orientación del gobierno de turno, comprobamos que estas cuestiones no son meras disquisiciones abstractas, a la vez que no podemos dejar de constatar que la Estética como materia filosófica se convirtió en todo un síntoma o símbolo de las pugnas entre liberales y conservadores. Por eso no es irrelevante que Giner escribiera estas lecciones precisamente en esos años, después de su importante trabajo de traducción del Compendio de Estética de Krause, aparecido como libro completo en 1874, y que aún retomaría después en una segunda edición ampliada a la luz de las ediciones extensas de la Estética y las obras sobre teoría e historia de la música krausianas (Krause, 1883).

Pero ¿qué quería decir que el filósofo estudiase Estética? De un lado que la belleza y las bellas artes eran un tema digno del pensamiento más especulativo; pero también que el profesional y estudioso del arte, a la hora de establecer criterios de valoración y en definitiva de ejercer la crítica artística, debería tener y manejar un horizonte filosófico de los problemas, y también un escrúpulo crítico con su misma forma de juzgar y de 
manejar sus juicios sobre las obras, a la hora de aplicar una supuesta regla general o canon para clasificar y valorar las obras de arte. La formación del estudioso de la literatura, que incluía la Estética como un complemento a su educación histórica y estilística, debía adquirir los vuelos necesarios de un ejercicio reflexivo y responsable de primer orden. En este sentido, recordando en parte lo que había sido la discusión en torno a la crítica del arte en el romanticismo alemán, se puede decir que Giner aspiraba a presentar, ya en estas lecciones, los rudimentos para una correcta y renovada idea de la crítica del arte.

La revisión de la idea de crítica no va a ser un excurso coyuntural o un añadido a la teoría estética, sino que viene dada desde la misma concepción de la Estética como ciencia y a la vista del programa entero de su desarrollo; para ello, Giner dialoga activamente con el proyecto de Krause, que en la Estética, en su sentido amplio, vería tres grandes partes: la puramente filosófica, la histórica-empírica y, reuniendo las otras, la filosófico-histórica (Krause, 1882: 7). En sus lecciones de Estética, Krause era consciente de desarrollar, y aun de modo no completo, la parte filosófica. Aún podría haberse completado una fundamentación metafísica mayor de estas lecciones en lo que compete al concepto de belleza, sobre todo, y también en lo referente al concepto de arte y arte bello, tal como haría en sus lecciones sobre el sistema de la Filosofía (Pinilla, 2002: 322 ss.). La parte histórica o empírica requeriría un estudio desde la experiencia del desarrollo de las artes en su diversidad y estilos, y también de la misma idea de belleza. Krause entiende que la belleza es un concepto absoluto, pero no deja de asumir que el ideal de la belleza se va desvelando a lo largo de la historia, y, en este sentido, la parte histórica sería solo artística sensu stricto. Giner corroborará y apoyará este amplio planteamiento. Finalmente, la parte tercera sería una filosofía a la vista de ese desarrollo histórico y empírico. Krause es consciente de que no puede desarrollar esta parte, y hay que recurrir a algún manuscrito y sobre todo quizá a sus trabajos musicológicos amplios (su Teoría de la Música y su Historia de la Música) para entender las dimensiones de su proyecto y sus tres fases o partes (Pinilla, 2013: 121 ss.).

En la segunda lección de las mencionadas, bajo el título «El carácter de la Ciencia Estética», planteará Giner este asunto, resultando en ella al final el esquema general de esta disciplina y el carácter de cada una de las partes. Es ahí donde aparecerá el tema de la Crítica. Giner señala que la Estética hegeliana en realidad ha marcado el desarrollo de esta disciplina, aunque disiente de la idea de reducirla a una ciencia o filosofía del arte. 
Giner hace aquí una lectura sintética pero certera de Hegel, pues aunque en sus lecciones estéticas se aborde preliminarmente el concepto de belleza y de belleza natural, no es este concepto en realidad el rector de su pensamiento estético, sino el de «la idea de lo bello artístico» (Idee des Kunstschönen) (Hegel, 1986: 127 ss.), acorde con la valoración hegeliana del arte como creación del espíritu que, en este sentido, está en un nivel superior a cualquier belleza natural.

Hecha esta consideración, Giner plantea abordar «el problema de la belleza» apelando «a la observación y al sentido común culto y no a teorías preconcebidas» (Giner, 1878: 4), y desde ahí no duda en señalar que es la belleza el objeto central de la Estética, pues el «fenómeno estético» puede encontrarse en las obras de arte, por supuesto, y se diría que en ellas de modo muy especial, pero también «en la vida ordinaria». En realidad, como en otras ocasiones, Giner sigue aquí a Krause, quien comenzaba sus lecciones estéticas apelando al sentido común, para desgranar la belleza como su objeto central. La consideración de la belleza más allá del arte, en el enfoque krausiano, no es en realidad un problema de grado, como plantearía Hegel, sino que, antes de nada, hay que considerar lo bello como un rasgo esencial de lo real y de Dios, entendido este como Ser y Ser supremo. Como tal, la belleza es susceptible de manifestarse en todas las cosas, sin perjuicio del valor ejemplar del arte. Pero Giner no quiere en sus lecciones prescribir grandes fundamentos metafísicos, sino, siguiendo el objeto didáctico de estas, acompañar al pensamiento del oyente y del lector.

La asunción de la belleza como una dimensión de la realidad posee para Giner tres niveles diferentes aunque interrelacionados: $\left.1 .^{\circ}\right)$ percibir lo bello en un objeto individual, como algo específico y diferente de otras características; $2 .^{\circ}$ ) juzgar su valor y grado de belleza; $3 .^{a}$ ) y finalmente indagar las razones y fundamentos de nuestro juicio. A estos niveles Giner los llama problema individual, problema crítico, y problema general o filosófico, que pondrá en relación con las tres partes o «ciencias particulares» pertenecientes a la Estética: la «Historia de las manifestaciones estéticas»; la «Estética crítica», que sería una de las dos partes de la Estética filosóficohistórica; y la «Filosofía de lo bello». Al enumerar estas ciencias, Giner coloca la tercera (Filosofía de lo bello) en segundo lugar. Este cambio es significativo, pues atiende ya no a una exposición descriptiva ascendente, que correspondería a las acciones de observar, juzgar y buscar el fundamento; sino a un orden sistemático, en donde el juicio crítico ha de tener como base tanto la observación empírica e histórica como la fundamentación filosófica. La crítica así se inserta, sin agotarla tal vez, en la parte 
más compleja o sintética de la Estética, en donde se han de combinar los conocimientos histórico-empíricos con la fundamentación filosófica en primer lugar de la idea de belleza, como concepto central de todo el fenómeno estético.

Aunque Giner está hablando del carácter y de las partes de la disciplina de la Estética, ya podemos suponer el alto valor que asignaba al oficio de crítico de arte, incidiendo con esto en un contexto de preocupación de muchos intelectuales y literatos españoles por armar a la crítica de una fundamentación sólida, y curarla de caer en un mero ejercicio arbitrario y caprichoso. En su estudio sobre la Teoría del arte del krausismo español, Francisco J. Falero nos recuerda con detalle este contexto que se remonta a las preocupaciones del movimiento ilustrado y romántico, aludiendo a autores como Milá y Fontanals o Menéndez Pelayo y su Historia de las ideas estéticas, entre cuyas motivaciones, señala, estaría esa necesidad de fundamentar la crítica del arte desde la misma historia y conceptos de la Filosofía y la Estética (Falero, 1998: 93 ss.). En esa línea incluye también Falero a quien fuera maestro de Giner en temas estéticos: Francisco Fernández y González, y también alude a institucionistas como José Echegaray, Hermenegildo Giner y el mismo Manuel de la Revilla, del que analiza un interesante discurso pronunciado en el Ateneo madrileño en 1879. Se trata de un discurso resumen dentro de la sección de literatura, que llevaba el significativo título de «Principios a que debe obedecer la crítica literaria para influir provechosamente en la educación del gusto y en el desarrollo del arte». Al parecer, Fernández y González había impartido un curso sobre «Crítica de literatura y artes» entre 1876 y 1878 en el Ateneo, del que no se conserva su contenido. Fernández y González contribuyó sin duda a presentar en el ámbito cultural español la Estética como una ciencia filosófica de primer orden, y en íntima relación con el desarrollo último de la filosofía, especialmente en Alemania a partir de Kant, el romanticismo y el idealismo, momento que históricamente coincide también con la necesidad de una refundación de la crítica literaria y del arte en sus implicaciones filosóficas, culturales y políticas.

Las lecciones de Giner son coetáneas a los cursos y discursos del Ateneo mencionados, y por ello sus alusiones a la Crítica y su ubicación y fundamentación sistemática cobran especial relevancia y significado. Giner apela inicialmente al problema de una ubicación sistemática de la Crítica dentro del plan completo de la ciencia estética, con lo que el oficio del crítico encuentra ya de partida un horizonte científico y filosófico de indudable alcance. En realidad Giner, con las partes señaladas de la Estética, 
sigue muy directamente la división ya aludida de Krause, que organiza el plan completo de esta ciencia en una parte histórica o empírica, una parte filosófica, y una tercera que sería una «Filosofía de la Historia de lo bello y del arte» (Pinilla, 2005: 72; Krause, 1837, §4: 3). En la primera edición de la traducción del Compendio de Estética de Krause, Giner traduce literalmente la denominación de esta parte (Krause, 1874: 5), si bien en sus lecciones del BILE (1877-1878), como hemos visto, no duda en incluir la Crítica en esa tercera parte; en la segunda edición del Compendio de Estética modifica la denominación de esa parte, nombrándola como «ciencia filosófico-histórica o crítica de lo bello y el arte» (Krause, 1883: 4). No hay que ver, no obstante, esta variación como una suerte de incursión externa, o adaptación de esta parte a las ideas ginerianas. El mismo Krause observa que en esta parte se hace posible una acogida y un aprecio de lo bello y el arte en todas sus manifestaciones:

Ese conocimiento científico [la Filosofía de la Historia de lo bello y del arte] implica primeramente que el que lo posee acoge todo lo bello que encuentra en la unidad de la idea [de lo bello], y lo comprende y aprecia, y por otro lado como artista configura con riqueza artística todo lo bello individual en la intuición íntima de la idea de lo bello (Krause, 1882: 7).

Esta declaración no aparece como tal en el Abriss der Aesthetik (Compendio de Estética), sino en las lecciones amplias de Estética, concretamente en las Vorlesungen der Aesthetik, que se publicaban póstumamente de la mano de Hohlfeld y Wünsche en 1882, y que Giner tuvo presentes a la hora de revisar la traducción del Compendio de Estética. La modificación aludida, aunque leve, vemos cómo se hace eco de la profundización en la articulación de esta parte por el mismo Krause, en confluencia con el planteamiento del propio Giner ya expresado con nitidez en sus lecciones estéticas impartidas en la Institución. Si reparamos brevemente en el pasaje aludido, vemos cómo, más que de un oficio concreto del crítico, Krause habla de una relación comprensiva o contemplativa, junto a una más directamente activa. El ser humano, desde la ciencia estética, quedaría facultado para ambas, tanto para el juicio y valoración de lo bello y el arte, como para la realización concreta de lo bello, en tanto que artista. Es sin duda un horizonte amplio en el que se inscribe la tarea del crítico, y que compartiría con la misma actividad el artista; un horizonte de conocimiento histórico y de reflexión filosófica, que, si no siempre presente, se señala como deseable, a la luz del amplio proyecto tripartito de la ciencia estética krausiana, y que Giner asume con viveza. 
Es verdad que las lecciones estéticas de Krause ni siquiera en sus ediciones amplias contemplan el desarrollo completo de las tres partes, siendo sin duda un programa ambicioso, acaso solo realizado en el campo de la teoría musical. Lo que sus lecciones desarrollan es más bien la parte puramente filosófica: una amplia filosofía de la belleza, una filosofía o teoría del arte y las teorías particulares de cada arte, faltando el desarrollo de la parte empírica e histórica y la parte tercera, filosófico-histórica. Ahora bien, ya en la teoría del arte (segunda parte principal de su Estética), Krause contempla, dentro de lo que llamará el círculo del arte, la figura del juez o del conocedor de arte (en el que se incluirían no solo los críticos, sino los historiadores y estudiosos del arte en toda su amplitud) (Pinilla, 2002: 876 ss.). Ese oficio en realidad, a la vista del programa completo de la Estética, debería partir, de acuerdo con lo expuesto, de una amplia fundamentación filosófica, del conocimiento de la idea de lo bello y del arte, así como de un conocimiento empírico e histórico del desarrollo del gusto y de las artes en los diversos pueblos y épocas.

Cuando Giner apela a las partes de la Estética, es interesante reparar en que procura reconstruir un proceso, que podríamos llamar más experiencial o fenomenológico, que no corresponde todavía directamente con el esquema sistemático y conceptual. Este planteamiento nos indica que Giner no solo está interesado en una suerte de legitimación académica o sistemática de la Crítica, sino que inscribe a esta en un marco amplio de relación con el fenómeno estético, en ese marco que va de la observación dispersa al juicio, y que apela en definitiva a la búsqueda de fundamentos. El horizonte amplio o macroscópico de este planteamiento experiencial se traduce en el desarrollo de un conocimiento empírico e histórico, una reflexión filosófica amplia, y una síntesis de ambos desarrollos. De estas partes, apunta Giner que es la Historia del Arte la más desarrollada de la parte empírica, dando a entender, acorde con el planteamiento krausiano, que habría una ciencia empírica e histórica más amplia que abordaría no solo el arte, sino el fenómeno de lo bello y lo estético en general. Esto, que en su momento podría parecer un planteamiento algo abstracto y con un referente impreciso, se ha demostrado un objeto fecundo en la Estética en el siglo Xx (en autores como W. Benjamin, Auerbach o H.-R. Jauss), que aborda también una historia de los modelos de experiencia estética (no simplemente un desarrollo de diferentes cánones estéticos).

Giner tiene a la vista el gran despliegue de la Estética hegeliana, que en principio consideraría el aspecto histórico y de desarrollo del ideal de lo bello artístico a lo largo de diferentes etapas o figuras desde la antigüedad 
(forma simbólica, clásica, romántica). Es significativo observar que en este sentido la propuesta hegeliana, que no duda en admitir como la dominante, no acaba de resultarle satisfactoria, y parece que no realizaría en realidad esa tercera parte de síntesis entre lo filosófico y lo histórico, siendo más bien un repliegue de los dos elementos hacia lo puramente filosófico. En otras palabras, vería una síntesis precipitada en el, de otro lado, magno programa hegeliano:

Para Hegel, la Historia del arte (a que reduce toda la de la belleza) no expresa sino la serie de los grados que necesariamente ha tenido que recorrer el espíritu en su manifestación, por ley indeclinable de su naturaleza: de donde el problema histórico en la Estética, como en todo (según el principio de la doctrina hegeliana) se convierte en filosófico, planteándose y resolviéndose en el dominio de la idea pura (a priori). Mas, de todos modos, la evolución del arte y la crítica de sus obras entra de un manera esencial, no por vía de mera aplicación y de ejemplo, en la Estética de aquel filósofo (Giner, 1878: 4).

Giner viene a ver de un lado una cierta reducción del problema histórico de lo estético a la historia del arte, y de otro cierta conversión urgente de lo histórico bajo el prisma filosófico. La concesión posterior, frente a estéticas más racionalistas, admite que en Hegel hay una consideración del arte y la crítica en sus desarrollos concretos. En otras palabras, a pesar de la censura a Hegel no piensa que supedite su análisis de modo artificial o forzado a su ideal de lo bello.

Al decir que no opera Hegel «por vía de mera aplicación», es posible que Giner tuviera en mente algunos estéticos franceses racionalistas, como Th. S. Jouffroy o Charles Lévêque, quien en su Estética precisamente entendía el abordaje del arte como una aplicación de los principios de la «ciencia de lo bello». En 1862 publicaba Lévêque en París La science du beau, étudiée dans sus principes, dans ses applications et dans son historie. Justo en 1878 aparecía en Valladolid la traducción de esta obra, con el título de Estética o Ciencia de lo bello, a cargo Santos Santamaría del Pozo, catedrático de Principios generales de Literatura y Literatura española en la universidad vallisoletana. En el prefacio del traductor, aclaraba que había traducido las dos primeras partes: los principios sobre lo bello y las «aplicaciones», donde abordaba el arte, la poesía y la elocuencia. Quedaba clara la intención de suministrar principios sólidos a los estudiantes de literatura e insistía este estudioso de la literatura en la idea de «aplicación» de los principios. 
Giner abogaba naturalmente por una reflexión filosófica y de los principios, pero se distanciaría de una aplicación meramente descendente o deductiva de un principio o un ideal a la obra concreta o al ejemplo o caso analizable, sea en el oficio crítico, sea en la mera apreciación de algo bello. En las notas a la traducción del Compendio de Estética de Krause, encontramos una alusión crítica precisamente a los estéticos racionalistas franceses, citando expresamente a Lévêque y Jouffroy, que pretenden juzgar algo bello desde una idea previa o un ideal. El pasaje es un momento central de la indagación krausiana de lo bello, en la que el filósofo alemán afirma que algo bello es bello «por lo que es, no por lo que significa, de ahí que tampoco se le conozca comparándolo con otro término, siendo como tal incomparable, ni por tanto con lo feo y deforme, ni con esferas superiores de belleza, ni con la idea de esta, ni con el bello ideal [...], sino que debe lucir por sí propio, por ser precisamente la idea realizada, el ideal vivo» (Krause, 1883, §12).

Es al final de esta reflexión (Compendio de Estética, §12) cuando Giner introduce en nota la crítica a la Estética racionalista francesa. Krause plantea esta importante tesis en la dilucidación de la objetividad de lo bello y la idea objetiva de belleza, y defiende, en una línea cercana en esto a como lo haría Solger (Pinilla, 2002: 479 ss., 487), la entidad de algo bello frente a su significado, o el ideal bajo el que se sustenta. Si algo es bello por el ideal o la idea a la que remite, lo bello quedaría como mera mediación, y se disolvería la patencia y el valor intrínseco de eso bello, como mero signo o alusión, desplazándose el problema de la belleza a ese ideal. Esa reivindicación de la fuerza de algo en su belleza concreta la encontramos en algunas de las más señeras consideraciones de la metafísica de lo bello, así en el Fedro platónico (Platón, 1988, 250d ss.), o en Kant, cuando determinaba que el juicio estético puro, si debía prescindir de todo concepto, no podría ser un juicio basado en un ideal de belleza (Kant, 1986, §17).

Nos interesa destacar la ubicación de esa alusión, en relación con el tema de la organización sistemática de la Estética y la ubicación de la Crítica. Para Giner estos asuntos tienen una clara relación, y advierte que, tanto en las estéticas espiritualistas e idealistas como en las positivistas, se asumen de manera rígida y abstracta una serie de principios generales; aunque en el caso de las positivistas, estos principios queden sin reconocer (Giner, 1878: 4). Este punto de ubicación filosófica de la Estética posee en Giner un componente gnoseológico y epistemológico claro, como veremos, pero acaso tiene también directamente que ver con la naturaleza de lo que se juzga, esto es, la belleza; un fenómeno del que podemos y 
debemos pensar e indagar su esencia, pero del que no podemos derivar reglas o preceptos de modo lineal a la hora de evaluar una obra concreta.

El hecho de no reconocerse las tres partes aludidas, su independencia a la vez que su relación, es a ojos de Giner un error filosófico que está en la base de muchas cuestiones y aporías de la Estética de su tiempo, que confunden una y otra parte, y provocan un desorden de diversas cuestiones, lo que llevaría de modo erróneo a asumir tanto la crisis de la teoría y de las reglas y preceptos universales para el arte, como la visión del mismo arte como algo ya desplazado o subalterno en nuestro presente, frente al dominio de la ciencia, acorde con las tesis hegelianas del carácter pretérito del $\operatorname{arte}^{4}$. Giner apuesta por un desarrollo independiente y a la vez conjuntado de las tres partes, labor que entiende desborda esas lecciones sumarias y requeriría «las fuerzas de un reformador» (Giner, 1878: 4).

\section{Entre lo universal y lo particular: la idea de Crítica y la cuestión de la creación artística}

Una vez tenemos presente la visión crítica de Giner respecto a la idea de «aplicación» sin más de un principio a un análisis de una obra o un ejemplo concreto, deberemos revisar con distancia el mismo título de sus lecciones: «Estética con especial aplicación a las bellas artes». Queda claro que Giner no espera de la Estética una aplicación en el sentido censurado. Por eso, sin desatender el asunto o enfoque de estas lecciones, en la tercera nos habla de «las ideas relativas al valor práctico de la Estética», aclarando de partida en qué consiste esa dimensión práctica o, cabría decir, aplicada de la Estética, que no es sino la capacidad de la ciencia estética para proporcionar principios generales que orienten acciones concretas. Esas acciones a veces parece que se moverían en un plano puramente crítico intelectual, pero Giner piensa sin duda también en el plano práctico operativo del mismo artista. En este sentido, el problema del juicio -o la aplicación de un principio a un caso- no quedaría circunscrito al oficio habitual del crítico, sino que apelaría también al problema mismo de la creación y la producción del arte desde el seguimiento, aplicación u observación de unos principios o leyes.

4. En su prefacio a Estudios de literatura y arte, fechado el 20 de junio de 1876, Giner hacía una aguda crítica de las tesis hegelianas sobre el fin del arte, reconociendo un momento crítico, pero no por eso de final en el arte de su tiempo (Giner, 1919: XXXI ss). Sobre este asunto, cf. Pinilla, 2009a: 144 ss. 
Giner acude aquí de nuevo a la historia y nos presenta dos grupos opuestos: aquellos que niegan el valor práctico a la Estética, considerándola solo como una ciencia teórica (y más centrada en la idea de belleza), y aquellos que, por el contrario, sí defienden el valor práctico de esta disciplina (y se centran más en el arte). Hay otros, como por ejemplo Vischer, según nos indica Giner, que colocan la Estética más allá de esta división entre lo teórico y lo práctico. De otro lado, donde más se encuentra un tratamiento aplicado de los principios estéticos a la estimación concreta del arte o a la caracterización de las reglas de la creación, es en el mundo de los tratadistas, llamados de modo general «preceptistas», que han escrito obras con esa intención explícita de determinar principios y criterios orientativos a la acción y a la contemplación. Así, piensa Giner en el elenco clásico de Poéticas, desde Aristóteles, Horacio o Vitrubio, y los tratadistas y artistas del Renacimiento, hasta los poetas, artistas, historiadores, tratadistas y críticos del Neoclasicismo, como Boileau, Raphael Mengs, Hugo Blair, Winckelmann o Moratín. El objeto y método principal sobre todo de los tratados neoclásicos era establecer unos cánones a partir de obras ejemplares que servirían como modelos para imitar. Giner cree que este planteamiento pretende convertir en absoluto y modelo fijo e inmóvil algo que en realidad es concreto y temporal, y que en general en este planteamiento de los llamados preceptistas (entendemos que sobre todo en los neoclásicos) hay una falta de análisis filosófico previo de la idea de belleza y de arte como tal; lo que lleva a no distinguir en las obras maestras lo que tienen de universal y lo que pertenece a su tiempo y a las circunstancias históricas. De otro lado, no deja de ver Giner una tendencia a dogmatizar en exceso los criterios sobre el hacer artístico de uno u otro tipo heredado de tratados clásicos, como pueden ser las unidades aristotélicas de la tragedia, o el canon dórico de Vitrubio.

Giner no niega el valor de muchas aportaciones de los llamados preceptistas, sino que rechaza sobre todo su método y su afán de establecer la crítica de arte como una suerte de código o conjunto de cánones y recetas que, más que criterios universales, retratan una concepción histórica y concreta del arte y de la producción artística, la neoclásica, que no hay que considerar como la única posible y ni mucho menos la más perfecta, como de algún modo sí pretendían prescribir teóricamente este tipo de tratados.

Frente a este universalismo rígido y excluyente de los preceptistas, ubica Giner la reacción romántica, que negaría la existencia de toda regla para el arte, y sometería la creación a la «dictadura del genio». Hay que señalar que, en sus artículos literarios, Giner distingue entre un 
romanticismo excesivo y uno más «sensato», en relación con el sentimiento y la arbitrariedad del genio, apreciando en este movimiento en todo caso la conexión con la vida y la raíz genuina de lo popular, algo que quedó extinto en el clasicismo francés más radical. En el campo concreto de la crítica, no parece Giner valorar explícitamente la preocupación de autores como F. Schlegel por renovar precisamente la actividad del crítico desde la nueva filosofía alemana. Se puede decir de otro lado que en Giner hay un progresivo distanciamiento y matización del romanticismo, al menos en la utilización de este término, que contrastaría con una inicial adhesión a este movimiento en su factura más original (romanticismo alemán e inglés) ${ }^{5}$.

En este sentido encontramos un pasaje muy interesante para nuestro tema en su artículo "Consideraciones sobre el desarrollo de la literatura moderna». Giner está sintetizando ahí dos ingredientes fundamentales en el arte de toda época, a saber: la combinación y presencia de aspectos universales, referentes a las «leyes necesarias de lo bello»; y la relación con lo temporal y con el contexto de la civilización en el que cada obra nace. En otras palabras, el buen arte debe combinar «lo accidental y lo absoluto». Si falta alguno de estos aspectos, las obras quedarán condenadas a ser producciones caducas y efímeras. A continuación, en la versión primera de este pasaje, Giner señala que «[t]ales son los fundamentos de la esthética del romanticismo» (1862: 423). En la versión revisada de este texto, pocos años después, preparada para su libro Estudios literarios, ya aparece sustituida la expresión «esthética del romanticismo» por la de «crítica moderna» (1866: 15). Esta sustitución se podría interpretar, de un lado, como un distanciamiento, pero de otro, como una comprensión del romanticismo en su impulso original en cuanto momento fundador de una nueva idea ya no de arte, sino de crítica de arte como tal, que asumiera tanto el elemento universal y metafísico del arte, cristalizado en la idea de belleza, como el aspecto temporal, histórico y circunstancial.

Si volvemos a la alusión a «los críticos románticos» en las lecciones del BILE, vemos que esa consideración de la «Crítica moderna», sea identificada con el mismo romanticismo o con su sustitución, no aparece, y pervive más la idea negativa y polarizada de una reacción romántica frente

5. Véanse los cambios y matizaciones en las alusiones al romanticismo a la luz de la comparación de la primera edición (1862) y la posterior revisión (ya de 1866 y aún reeditada por Giner en 1876) del importante artículo «(Algunas) consideraciones sobre el desarrollo de la literatura moderna». Sobre este asunto, cf. Pinilla, 2009a: 143 ss. También, Giner, 1919: 231, 233. 
a los excesos del preceptismo neoclásico y su imposición abstracta de cánones. Giner personaliza esta posición en Victor Hugo, pensando seguramente en su célebre «Prefacio» de Cromwell (1827), donde se defiende de las censuras neoclásicas y apela a la creación libre de la subjetividad del artista frente a cánones establecidos. Giner piensa que ese modo de reacción romántica y defensa de la libertad subjetiva provoca una negación de la capacidad práctica de los principios en la crítica heredera del romanticismo, como se había dado en otros autores anteriores que basan la belleza en criterios subjetivos, como Diderot, Hume o Taine, o, de otro lado, se daría en propuestas estéticas que apelan a la creación como un proceso misterioso o inconsciente: es el caso de las Estéticas de Eduard von Hartmann, o de los estudios sobre la percepción de Helmholtz, denotando Giner con esta referencia un agudo conocimiento de las implicaciones de las investigaciones de este físico, que influiría en autores como Freud (Cros, 2011). El liberalismo de Spencer será también a juicio de Giner un elemento que contribuye a este desprestigio o abandono de la pretensión normativa práctica de los principios estéticos.

Curiosamente ambos extremos, tanto los preceptistas como los románticos y partidarios de un carácter arbitrario o no consciente y racional de la creación artística, tendrían en común la ausencia de una indagación filosófica rigurosa del fenómeno estético en sus leyes y de un análisis cuidadoso del modo de interpretar o considerar esas leyes en los fenómenos o casos concretos a la hora de juzgar una obra de arte.

Por eso la solución que plantea Giner en la siguiente lección $\left(4 .^{\mathrm{a}}\right)$ acerca del valor práctico de la Estética y sus principios contiene una exposición que ya no es histórica, sino mucho más sistemática y argumentativa. Ahí es donde encontramos condensada su propuesta o consideración filosófica acerca del modo adecuado de aplicar los principios al caso concreto, y esto tanto para una consideración o juicio sobre la obra concreta, tarea propia del crítico, como para la acción misma del artista a la hora de producir su obra, de acuerdo con unas reglas o leyes generales. A pesar de las alusiones a la parte crítica, Giner parece así resolver el tratamiento de esta parte en la que se pone en relación lo general con lo particular, como campo práctico de aplicación de los principios, tanto en el ejercicio del juicio como en la misma acción artística.

Giner comienza describiendo un panorama errático a la hora de entender el sentido de los principios generales de la Estética y su aplicación en los casos particulares, como si «el artista tuviese una guía exterior para cada uno de los diversos pormenores a que debe atender» (1878: 19). 
Como se ve, Giner piensa primeramente en el artista más que en el crítico, si bien abordará desde este dilema el problema de la elaboración del juicio concreto a partir de un principio estético general.

La explicación de ese estado de error es que hay una oposición radical entre el principio general y el caso individual. La regla no puede «aplicarse de manera inmediata y directa», pues «se necesita enlazar ambos extremos, lo universal y lo particular merced a un proceso intermedio de interpretación y asimilación» (Giner, 1878: 29). Se podría aquí decir que Giner apela a una teoría comúnmente aceptada de juicio, y que Kant perfiló con agudeza en su idea de «capacidad de juzgar» (Urteilskraft) como facultad mediadora que hace posible, con el concurso de la imaginación y el esquematismo trascendental, subsumir lo particular en lo universal, esto es, poner en relación el fenómeno concreto con los conceptos del entendimiento. Esta idea aparece ya en el contexto de la crítica kantiana del conocimiento, en la Crítica de la Razón pura, y queda enriquecida al ahondar en ese especial tipo de juicio que son los juicios estéticos en la Crítica del Juicio (Kant, 1986a: 183 ss; 1986b, Introd. IV). En efecto, en su tercera Crítica acuña ese interesante concepto de «juicio reflexionante», por el que en juicios como los estéticos, y también en los teleológicos, se daría una subsunción sin que lo universal esté dado.

Giner no apela a esta precisa conceptología kantiana, pero lo que nos dice queda sin duda iluminado desde ella, pues apunta que, en el caso de la misma producción de la obra, se da la conjunción de lo universal en un complejo proceso que entraría en cada detalle de la misma obra:

Pero cada pormenor, cada momento de ejecución del caso concreto forma por sí un nuevo caso, con exigencias análogas correspondientes, el problema se repite hasta el último acto en que la obra termina: hasta el último golpe de cincel, por ejemplo, del escultor en su estatua (Giner, 1878: 29).

No duda don Francisco en calificar esto como un «proceso complicadísimo de continua y mutua referencia» entre el principio general y la obra. Por eso no basta conocer las leyes generales, sino que se precisan numerosas dotes de talento, tacto, dominio de la materia, etc., que quedan resumidas en su más alta expresión en la idea de «genio». Giner sigue razonando aquí de modo muy parecido a la idea de lo reflexionante en Kant, o al trabajo de la imaginación en la idea estética, que produce una representación que no se puede precisar desde un lenguaje o concepto determinado (Kant, 1986b, §49). Giner no alude como hemos dicho a la Crítica del Juicio, aunque sí deja indicado un inicial diálogo con los 
teóricos del inconsciente en la creación artística (E. von Hartmann, Dreher, Helmholzt), algo ya implícito en la idea kantiana de genio (ibid., §46).

Podemos preguntarnos, a la vista de lo planteado, si se está pensando aquí más en el puro problema de la creación artística o en el ejercicio de relación y aplicación de un principio general estético a una obra determinada. Aunque parece que, por los ejemplos dados, Giner piensa en el primer caso, esto es, en la creación del genio artístico como tal, la continuación de sus argumentos nos lleva más bien no solo a incluir la segunda opción, sino también a ampliar esta cuestión a un problema general de la interpretación de los principios en relación con la circunstancia, caso o acción concretos. Giner señala en este sentido que este problema de la relación entre lo universal y lo particular no es «peculiar de la producción estética, sino de toda obra de la vida en sus varias esferas» (Giner, 1878: 30). Estamos aquí ante la implicación del arte y del modelo de acción y comportamiento que afecta a la vida humana en toda su amplitud. Pero ¿y la crítica? ¿Dónde queda esa parte de la Estética que sintetiza precisamente lo empírico e histórico con los fundamentos filosóficos? ¿No sería esa parte el fundamento estético-filosófico de la actividad concreta del crítico de arte? Parece que así podría ser, en combinación con la reflexión filosófico-histórica, pero, a la vista de esa ampliación, esa síntesis entre lo filosófico y lo concreto (empírico e histórico) no sería solo un problema específico de la dimensión estética.

De otro lado, a juzgar por el interés que manifiesta Giner al principio de sus lecciones y en otros lugares por la fundamentación renovada de la crítica, uno echaría en falta una explicitación más clara del oficio del crítico o al menos del tema en sí del juicio estético sobre una obra concreta a la luz de los principios. En otros textos, en efecto, Giner apunta algunas condiciones de ese tipo de juicios, no como ejercicio periodístico o actividad profesional, sino en su sentido educativo más amplio. Así en un apunte sobre una excursión, titulado «La crítica espontánea de los niños en bellas artes», fechado en 1885, don Francisco señala con nitidez los dos momentos indispensables del enjuiciamiento de una obra. En primer lugar, «la definición de la obra, definición que comienza por la vaga e instintiva percepción de sus notas, hasta que la reflexión va fijándolas una a una y concluya para resumirlas en una característica sintética»; y en segundo, el «juicio respecto al mérito comparativo» de la obra en relación con otras (Giner, 1925: 57). Esto es, toda crítica tendría un momento de definición y otro de valoración y comparación. Como nos ilustra bien el citado apunte, la crítica ha de surgir en todo caso de la observación y la 
valoración directa y personal de la obra, aunque luego sea asistida desde el razonamiento y los conocimientos teóricos y filosóficos.

Pero si volvemos a las citadas lecciones, comprobamos que Giner hace una interesante y original alusión que redefine su argumentación, haciéndola aplicable al crítico y a quien se enfrenta a una obra ya acabada desde la mera actividad observante, judicativa y valorativa. Esa alusión es del mundo del Derecho, ámbito de especialización universitaria de Giner. Concretamente se refiere a la Escuela Histórica de Savigny, por «abrir el camino de la recta idea de la interpretación jurídica, como el proceso de asimilación y adaptación individual de la regla legal al caso práctico, de lo cual da un ejemplo la sentencia del juez» (Giner, 1878: 30). En efecto, en sus escritos jurídicos y sobre el concepto de la ley, Giner critica un racionalismo mecánico que aplique sin más y con rigidez inamovible la ley, por perfecta que pueda ser, al caso concreto, y se imparta desde ahí justicia. La justicia debe proceder a esa interpretación y relación de lo universal y lo concreto en sus circunstancias singulares de espacio y tiempo. Esto no es caer en un arbitrarismo o en un causalismo inconsistente. En un momento histórico, reflexiona Giner, el imperio ilustrado de la ley fue necesario para cribar el gobierno humano establecido desde el privilegio y la arbitrariedad, en definitiva desde la opresión y la injusticia, pero una vez conseguido un nivel de legalidad y de moralidad en la relación libre entre las personas, la aplicación ciega y rígida de la ley es, como vemos, un acto en contra del mismo hecho de juzgar y de valorar lo concreto a la luz de los principios ${ }^{6}$.

Otro campo interesante que Giner señala como ejemplo es el del dogma religioso y su relación con la «infinita variedad con la que se lo asimila, lo comprende y expresa el pensamiento de cada hombre, conforme su individualidad y su cultura» (Giner, 1878: 30) ${ }^{7}$.

6. Además de las lecciones de Filosofía del Derecho y otros numerosos escritos jurídicos ginerianos, son de especial interés para este asunto dos artículos de Giner de 1908 en torno al concepto de ley: «Sobre el concepto de la ley en el derecho positivo» y «Acerca de la función de la ley»; ambos reeditados con ocasión del quincuagésimo aniversario de su muerte: Giner, 1965: 17-38. Cf. también Pinilla, 2009b: 33 ss.

7. Desde aquí se podría seguir muy bien una de las claves del interesante planteamiento krausoinstitucionista sobre la religión y la educación, abiertas a la pluralidad y variedad religiosa, y alejadas tanto del dogmatismo religioso como de un laicismo cerril o una visión disolvente o relativista de lo religioso. Sobre el tema de la religión en el krausismo, cf. E. M. Ureña, 1996. A este respecto recordamos la traducción que hizo Giner del texto de Leonhardi «Religión y ciencia» (incluido en Giner, 1922), que tanto influyó en todos los profesores institucionistas. 
Sin duda, la educación del gusto y del juicio estético sería para Giner una magnífica escuela, si no imprescindible, para el ejercicio de esa interpretación y esa relación entre lo universal y lo particular, ese complicado proceso intermedio para el que no dudaba en requerir facultades geniales. Dicho ejercicio se alejaba tanto del arbitrarismo subjetivista, del juicio meramente caprichoso, como de un presunto racionalismo a ultranza. La opción gineriana no se autocomprende como un racionalismo débil o abierto a la circunstancia:

Nada más racional, según lo dicho, que protestar y condenar los cánones de los preceptistas, que quieren convertir los principios en recetas, esto es, en fórmulas abstractas, monótonas, incapaces de prestarse a aquella adaptación, y para las cuales nada representa el elemento individual (ibid.).

El enfoque gineriano permite leer las afirmaciones de los grandes teóricos y filósofos del arte como indicaciones y sugerencias, nunca como dogmas rígidos, y con ello libera al discurso filosófico de un mal trazado de la relación con la práctica que siempre resultaría tirante, y que, aun en nuestra actualidad, por un celo mal entendido en el ejercicio del pensamiento o de la acción creativa, presenta conflictos y ángulos oscuros que, a la vista del meridiano planteamiento gineriano, deberían estar más que resueltos, propiciando antes que nada una colaboración fecunda entre acción creadora y pensamiento; un pensamiento que, cuando se ejerce como crítica concreta, no deja de tener un tanto de verdadero arte.

\section{La actividad de Giner como crítico. Una meditación vital del presente artístico y la cultura}

A lo largo de su amplia y variada producción, y también en el marco de su actividad pedagógica y docente en la Institución Libre de Enseñanza, Giner nos brinda ejemplos vivos y muy válidos de su ideal de crítica, que como vemos apela a un horizonte fundamental de la relación humana entre lo universal y lo particular. Basta recordar sus artículos sobre la nueva pintura en Inglaterra (los prerrafaelistas) y sobre el impresionismo francés, sus numerosas críticas literarias, sus artículos sobre música y escultura, su interés por las artes decorativas y por el nuevo movimiento de Arts \& Crafts, o sus estudios sobre artes industriales ${ }^{8}$. A estos trabajos habría que

8. Hace unos años, Adolfo Sotelo publicaba una espléndida antología de Giner, titulada El Arte y las Letras y otros ensayos, donde precisamente potenciaba esta faceta amplia de 
añadir sus numerosos artículos sobre la arquitectura y el patrimonio artístico tanto de España como de Portugal, reunidos en ese maravilloso libro titulado Arqueología artística de la Península, en el que Riaño compilaba y ordenaba buena parte de estos trabajos (Giner, 1936). En todos estos escritos muestra Giner un conocimiento de detalle que se manifiesta en la observación y la información sobre las obras y los diversos movimientos o planteamientos estéticos. No ahorra Giner la crítica, pero siempre orientada desde sólidos fundamentos provenientes de su pensamiento estético. Esos fundamentos no le impiden, sobre el trabajo mismo de análisis, elaborar conceptos, comparaciones o aserciones concretas; como, por ejemplo, esa interesante comparación de las categorías de lo romántico y lo simbólico en la nueva música y la cuestión de la ausencia del realismo o naturalismo en el desarrollo de la música (Giner, 1894: 118 ss.), o la valoración de la profundización de las nuevas técnicas del arte moderno, aún deficiente a su juicio, en la pintura contemporánea en comparación con la clásica, así como sus interesantes reflexiones sobre el dilema en la creación de su tiempo, entre lo decorativo y lo útil, de un lado, y de otro la creación autónoma de la obra (Giner, 1900: 89 ss.). No solo hay que ver en estos trabajos la curiosidad inagotable de un intelectual vivo y atento a cuanto le rodeaba, o las expresiones de un amante de toda manifestación artística, que también, sino el ejercicio pulcro y responsable del tránsito y la conjugación de la observación, el pensamiento de los fundamentos y la valoración concreta de cada obra y cada problema planteado.

De los numerosos trabajos aquí solo aludidos, cabría elegir algunos de los artículos de Arqueología artística de la Península, o quizá el que versa sobre el impresionismo, como modelos de ejercicio crítico. Por otro lado, el titulado «¿Qué son las artes decorativas?», aparecido en el BILE en 1900, es todo un ensayo sobre la situación del arte contemporáneo, especialmente atendiendo a las tendencias de ese momento pujantes en Inglaterra en el campo de las artes plásticas y la arquitectura, y donde reflexiona con lucidez sobre los nuevos desafíos tanto técnicos como sociales y filosóficos.

En todos los escritos mencionados advertimos que el crítico siempre da paso al gran pensador, atento a la vida en su manifestación plural; por eso contienen estos textos meditaciones de gran calado también sobre el problema del arte y de la expresión humana como tal, y su relación con

Giner como crítico y reunía, junto a otros escritos, buena parte de los artículos y textos de esta naturaleza: cf. Giner, 2007; cf. también Giner, 1886, 1894, 1895, 1900, 1916, 1919: 237 ss., 1923, 1926, 1936. 
la cultura y la historia, sin por ello desviar en ningún momento el rigor analítico de estilos, obras y autores. En su bello texto sobre «Cómo empezamos a filosofar», aparecido en el BILE en 1887 (Giner, 1925: 15 ss.), don Francisco no dudaba en poner la educación del gusto como un ejercicio afín y paralelo a la formación del mismo pensamiento, y en ambos casos, cifraba la madurez en esa formación cuando de la obra del filósofo, o de la obra de arte, se pasaba a admirar la vida y sus manifestaciones cotidianas y concretas como obras aún superiores o más sugerentes. En este sentido, cabe presumir que el ejercicio del crítico, insertado en el saber que propicia un pensamiento estético amplio, tanto en su conocimiento histórico del arte como en sus fundamentos filosóficos, se yergue para Giner como una actividad fundamental del saber humano abierto a enriquecer la vida en toda su extensión, tanto en nuestra relación con el entorno, como con los demás y con la historia.

\section{Bibliografía citada}

\section{De Francisco Giner de los Ríos}

\section{1.a. Artículos}

«Algunas consideraciones sobre la literatura moderna», Revista Meridional [Granada], I (1862), pp. 65-72; 109-116; 137-147; 212-218; 329-333; 413-425. «Estética con especial aplicación a las bellas artes», BILE [Boletín de la Institución Libre de Enseñanza], 20 (1877), pp. 77-78.

«Estética con especial aplicación a las bellas artes», BILE, 22 (1878), pp. 4-5; 24 , pp. 21-22; 25, pp. 29-30; 27 , pp. 45 ss.; 29, p. 61; 33, pp. 92-93; 35, pp. 106-107.

«La pintura contemporánea en Inglaterra. Los Pre-Rafaelistas», BILE, 222 (1886), pp. 129-132.

«La música romántica y la música simbolista», BILE, 404 (1894), pp. 117-119. «La pintura impresionista francesa», BILE, 420 (1895), pp. 83-90.

«¿Qué son las artes decorativas?», BILE, 480 (1900), pp. 88-91.

«Cartas literarias», BILE, 671 (1916), pp. 48-54.

«¿Por qué la escultura griega es superior a las demás?», BILE, 755 (1923), pp. 58-61.

\section{1.b. Libros}

Estudios literarios, Madrid, R. Labajos, 1866.

Estudios de literatura y arte. Obras completas, III, Madrid, La Lectura, 1919. 
Estudios filosóficos y religiosos. Obras completas, VI, Madrid, La Lectura, 1922.

Educación y enseñanza. Obras completas, XII, Madrid, La Lectura, 1925.

Estudios sobre artes industriales y cartas literarias. Obras completas, XV, Madrid, La Lectura, 1926.

Arqueología artística de la Península. Obras completas, XX, Madrid, Espasa-Calpe, 1936.

Ensayos y cartas. Edición homenaje en el cincuentenario de su muerte, México D. F., Tezontle / FCE, 1965.

El Arte y las Letras y otros ensayos, ed. Adolfo Sotelo Vázquez, Sevilla, Fundación José Manuel Lara, 2007.

\section{Otra bibliografía citada}

Cros, E., «El campo cultural de la segunda mitad del XIX y su articulación con la historia (Freud, Saussure, Poética, Pintura abstracta)», Sociocriticism, 26, 1-2 (2011), pp. 69-109.

FALERO, Francisco J., La Teoría del arte del krausismo español, Granada, Universidad de Granada, 1998.

HEGEL, G. W. F., Vorlesungen über die Ästhetik, I, Frankfurt a. M., Suhrkamp, 1986.

KANT, Kritik der reinen Vernunft. Werke in zehn Bänden, III-IV, ed. W. Weischedel, Darmstadt, Wissenschaftliche Buchgesellschaft, 1986a.

- Kritik der Urteilskraft und Schriften zur Naturphilosophie. Werke in zehn Bänden, VIII, ed. W. Weischedel, Darmstadt, Wissenschaftliche Buchgesellschaft, 1986b.

KRAUSE, K. Ch. F., Vorlesungen über die Grundwahrheiten der Wissenschaft, zugelich in ihrer Beziehung zu dem Leben. Nebst einer kurzer Darstellung und Würdigung der bisherigen Systeme der Philosophie, vornehmlich der neuesten von Kant, Fichte, Schelling und Hegel, und der Lehre Jacobi's. Für Gebildeten aus allen Ständen, Gotinga, 1829.

- Abriss der Aesthetik oder der Philosophie des Schönen und der schönen Kunst, Aus dessen Nachlass herausgegeben von J. Leutbecher, Dr. und Privatdozent der Philosophie und der Friedrich-Alexanders-Universität, Gotinga, 1837.

- Compendio de Estética, traducido del alemán por Francisco Giner, profesor de la Universidad de Madrid, Sevilla, Imprenta Girondés y Orduña, 1874.

- Vorlesungen über Aesthetik oder über die Philosophie des Schönen und der schönen Kunst, Aus dem handschriftlichen Nachlasse des Verfassers herausgegeben von Dr. Paul Hohlfeld und Dr. Aug. Wünsche (Angehängt: Drei Dresdner Vorlesungen, ein Brieffragment und eine Abhandlung über Schönheit), Leipzig, 1882.

- Compendio de Estética, traducido del alemán y anotado por Francisco Giner, profesor en la Institución Libre de Enseñanza y en la Universidad de Madrid, 
2. a edición aumentada, con la Teoría de la Música, del mismo autor, Madrid, Librería de V. Suárez, 1883.

LÉVÊQUE, Charles, La science du beau, étudiée dans sus principes, dans ses applications et dans son historie, 2 vols., Paris, Auguste Durand, 1861-1862.

- Estética o Ciencia de lo bello, traducida al español por D. Santos Santamaría del Pozo, catedrático numerario de Principios generales de Literatura y Literatura española en la Universidad de Valladolid, Valladolid, Imp. y Librería Nacional y Extranjera de Hijos de Rodríguez, 1874.

ORDEN, R. V., «La introducción de la Estética como disciplina universitaria: la protesta de Sanz del Río contra la Ley de Instrucción Pública», Revista de Filosofía, 26 (2001), pp. 241-271.

Pinilla, R., El pensamiento estético de Krause, Madrid, Universidad Pontificia Comillas, 2002.

- «Francisco Giner de los Ríos como traductor y receptor de la Estética de Krause», en P. F. Álvarez Lázaro \& J. M. Vázquez-Romero (coords.), Krause, Giner y la Institución Libre de Enseñanza: nuevos estudios, Madrid, Universidad Pontificia Comillas, 2005, pp. 53-106.

— «Arte y sociedad en Francisco Giner de los Ríos», en J. M. Vázquez-Romero (coord.), Francisco Giner de los Ríos: actualidad de un pensador krausista, Madrid, Marcial Pons, 2009a, pp. 137-198.

- «Autonomía moral e independencia judicial. Consideraciones a partir de Kant», en Miguel Grande (ed.), Independencia judicial: problemática ética, Madrid, Dykinson, 2009b, pp. 19-37.

- «La Arqueología artística de la Península de Francisco Giner de los Ríos y la contribución krausoinstitucionista a una historiografía artística del arte», en J. L. Mora et al., La Filosofía y las lenguas de la península ibérica, Madrid, Fundación I. Larramendi / Asociación Hispanismo Filosófico / Real Sociedad Menéndez Pelayo / Societat Catalana de Filosofía, 2010, pp. 209-228.

- «El pensamiento estético krausoinstitucionista», en José García Velasco \& Antonio Morales Moya (eds.), La Institución Libre de Enseñanza y Francisco Giner de los Ríos. Nuevas perspectivas, 2: La Institución Libre de Enseñanza y la cultura española, Madrid, Fundación Francisco Giner de los Ríos / Institución Libre de Enseñanza / Acción Cultural Española, 2012, pp. 278-302.

- Krause y las artes, Madrid, Universidad Pontificia Comillas, 2013.

Platón, Diálogos III: Fedón, Banquete, Fedro, ed. y trad. C. García Gual, M. Martínez \& E. Lledó, Madrid, Gredos, 1988.

Roviró, I., «La introducción de la Estética en España», Pensamiento. Revista de Investigación e Información Filosófica, 67, 251 (2011), pp. 149-159.

SÁNCHEZ DE ANDRÉS, L., «El pensamiento y la actividad musical de Francisco Giner de los Ríos. Iniciativas krausoinstitucionistas en el ámbito de la educación musical (1869-1815)», en J. M. Vázquez-Romero (coord.), Francisco 
Giner de los Ríos: actualidad de un pensador krausista, Madrid, Marcial Pons, 2009a, pp. 199-258.

- Música para un ideal. Pensamiento y actividad musical del krausismo e institucionismo españoles (1854-1936), Madrid, Sociedad Española de Musicología, 2009b.

UREÑA, E. M., «La crisis religiosa en la Alemania de mediados del siglo XIX y la alianza krausista para la religión», en P. Álvarez Lázaro (ed.), Librepensamiento y secularización en la Europa contemporánea, Madrid, Universidad Pontificia Comillas, 1996, pp. 93-128.

Fecha de recepción: 29-11-2015

Fecha de aceptación: 12-12-2015 


\title{
REFORMISMO, DIFUSIÓN Y LEGADO MUSICAL DE FRANCISCO GINER DE LOS RÍOS
}

\author{
FERRAN RIESGO MARTÍNEZ \\ Universidad de Alicante
}

\section{Resumen}

Francisco Giner de los Ríos creció y se formó en una España en que la música culta, ya perdida la ilusión de consolidar una ópera nacional propia, braceaba desordenadamente para no hundirse del todo, y la enseñanza musical reglada daba sus primeros y torpes pasos. En esta coyuntura, entre finales del siglo XIX y principios del XX, Giner comenzó a trabajar en varios frentes para cambiar las formas de enseñar música, siempre apoyándose en el ideario krausista. Este artículo propone un panorama de la tarea gineriana e institucionista en este campo, dividida en tres grandes cursos de acción: el impulso reformista en las enseñanzas profesionales de música, la importancia concedida a lo musical en la ILE, y la labor que la Residencia de Estudiantes o las Misiones Pedagógicas continuaron desempeñando tras la muerte del maestro.

Palabras clave: Giner de los Ríos; Eduardo Martínez Torner; Institución Libre de Enseñanza; Misiones Pedagógicas; Residencia de Estudiantes; música; educación; enseñanza.

\begin{abstract}
In the Spain where Francisco Giner de los Ríos was born and educated, classical music was desperately struggling not to sink completely. The hope for a consolidated national opera was definitely lost, and formal musical education was timidly starting to develop. Thus, in the late $19^{\text {th }}$ century, Giner, always loyal to Krause's aesthetics and social beliefs, started to work in order to change the way music was being taught. This article offers an outlook on the Institución Libre de Enseñanza and Giner's efforts on this field, divided in three main courses of action: the reform on professional music education, the importance of music within the ILE, and the way institutions like the «Misiones Pedagógicas» or the «Residencia de Estudiantes» continued Giner's work after his death.
\end{abstract}

Keywords: Giner de los Ríos; Eduardo Martínez Torner; Institución Libre de Enseñanza; Misiones Pedagógicas; music; teaching; education.

Anales, 27 (2015), pp. 107-129

DOI: 10.14198/ALEUA.2015.27.06 


\section{Obertura}

Cuarenta canciones españolas (Madrid, Residencia de Estudiantes, 1924) no es la obra más conocida del musicólogo asturiano Eduardo Martínez Torner, pero sin duda es la que está más estrechamente relacionada con los esfuerzos que Francisco Giner de los Ríos y otros intelectuales afines hicieron en favor de la música. En el prefacio de este libro escribe Torner:

Es innegable el valor de la música como medio para la formación del espíritu. Pero si, en realidad, las obras de los grandes maestros solo pueden ser gustadas actualmente por una minoría selecta, la canción popular, en cambio, encuentra en el espíritu de todos suficientes puntos de referencia para que sea escuchada con emoción, y ofrece, además, abundantes ejemplos de buen arte para que el sentido musical se desarrolle de modo adecuado hasta elevarse a aquel grado de sensibilidad que hace posible ulteriormente la comprensión de las obras geniales (Torner, 1924: XIV).

Son las palabras de alguien que habla de emprender una larga tarea, la de sentar las bases de una cultura y un gusto musicales elevados para todos los estratos sociales. Y, sin embargo, Torner recorrió solamente las últimas etapas - trabajó intensamente en la Residencia de Estudiantes y las Misiones Pedagógicas - de un camino que Giner había comenzado a andar mucho antes, al mismo tiempo que sentaba las bases de la futura ILE. Este, por su parte, escribía en el prólogo de Estudios de literatura y arte: "el nuevo [arte] ideal se halla en germinación, y tan segura como ha de ser en todas las esferas su victoria, tan imposible es lograrla en nuestros días» (Giner, 1876: XII); pero se trataba, con todo, de un alegato optimista: «prepararemos el suelo para que el germen eternamente sembrado arraigue, y prospere, y llegue en su día a florecer y dar fruto» (ibid.). El contenido es similar al del texto de Torner, pero, a pesar de las décadas que median entre ambos, la semejanza de los mensajes no revela una tarea infructuosa, sino, al contrario, la perseverancia y la coherencia de un proyecto reformista que se mantuvo hasta el fin mismo de la II República.

Giner y sus colaboradores no fueron los primeros en diagnosticar los males de la música española en el XIX, pero sí fueron el núcleo generador de un verdadero cambio en el panorama de la pedagogía musical. Los puntos más criticados por los intelectuales de la época eran el excesivo gusto por lo extranjero - lo italiano, sobre todo-, la baja cultura musical del público, el poco o nulo amparo prestado por los gobiernos, el mal estado de los teatros, la precariedad de los intérpretes y, en definitiva, la falta de una verdadera tradición musical viva. Son todas facetas de una 
misma realidad: pasados los esplendores del Renacimiento y el Barroco, en España el interés y el apoyo a la música se habían ido desplomando década tras década, y a finales del Ochocientos los intelectuales miraban hacia Europa con franca añoranza y amargura.

Don Francisco no era una excepción, y en sus escritos sobre educación se referiría ocasionalmente a las prácticas de otras naciones en materia de música ${ }^{1}$. El pedagogo era lo que por entonces llamaban «un filarmónico»: un amante de la música, que frecuentaba conciertos y reuniones privadas, se defendía bien al piano, y, desde su llegada a Madrid en 1863, fue un habitual de la Sociedad Filarmónica y la Sociedad de Cuartetos. Ello aportaba un trazo distintivo a su perfil de ilustrado y esteta, e indudablemente parte de su interés por la pedagogía musical nacía de la inclinación personal, de la propia experiencia artística. Sin embargo, las raíces más recias de su empeño reformador debemos buscarlas en el sustrato común de la doctrina krausista, que concedía una importancia capital a la faceta artística de la vida humana. Giner, que en Estudios de literatura y arte definía, siguiendo a Krause, la música como «el bello arte que expresa la belleza interior de la vida del ánimo en el mundo de los sonidos» (1876: 89), concretaba en la música esta capacidad especial del arte para influir en el espíritu de las personas:

Y pues que el sonido es esencial manifestación de la vida toda del sentimiento, así de la del cuerpo como de la del espíritu, pudiendo esta vida ser informada poéticamente mediante la libertad del espíritu y por ministerio de la fantasía en la bella vitalidad de los tonos; y pues la vida del ánimo humano se corresponde y concuerda con aquella de la Naturaleza, asemejándose por esto, en sus límites, a la divina, debe considerarse a la Música, en cuanto comprende la expresión de la vida entera de todos los seres, como un arte verdaderamente humano-divino (ibid.).

Conservamos las mayúsculas de Giner. Detrás de esta visión de la música está la triada platónica de belleza, verdad y bien, asumida a su modo por Krause y sus seguidores, que aparece aquí relacionada con ese equilibrio orgánico entre el hombre y lo divino, entre el hombre y la Naturaleza. Por consiguiente, la música debía jugar un papel central en la educación del individuo, en tanto que una de las bellas artes (y la de influjo más intenso

1. Vid. especialmente Obras completas, XVI: Ensayos menores sobre educación y enseñanza ( La enseñanza superior y técnica en Francia», 276 ss.). De ahora en adelante, las fuentes de textos de Giner se indicarán así: las iniciales OC (Obras completas) y, tras coma, el número de volumen de la edición de Espasa-Calpe, salvo en el caso de Estudios sobre literatura y artes (1876); aquí: OC, XVI: 276 ss. 
y sutil), y Giner mostraba en el «Prólogo» una preocupación sincera por el estado general del arte del momento. Una belleza «privada de toda su propia y sustantiva finalidad, como de toda virtud ética, y con esto de su dignidad y elevado sentido» (1876: XIV), no podía sino dañar la conciencia de los jóvenes: «de esta suerte, torcida la natural tendencia con que gravita hacia lo bello el espíritu, se pervierte y corrompe, por falta de dirección adecuada» (ibid.). Se entiende así que el objetivo central fuera lograr una influencia sólida, duradera y general en la sociedad española a través del arte. La circulación del arte bello, puro, que los krausistas distinguían del «arte útil» (vid. el mismo «Prólogo» a Estudios...), debía producirse de forma piramidal: unos pocos profesionales —músicos y compositoresdebían estar excelentemente formados para poder transmitir un objeto artístico puro a un público que había de estar educado en su recepción y aprecio; si era posible desde la infancia, tanto mejor, pues el propio influjo de la música y otras artes contribuiría a su crecimiento en esa «dirección adecuada» a la que se refería el maestro.

Para sostener esta estructura de comunicación Giner siguió tres cauces de acción principales, bien diferenciados: por un lado, la educación musical superior, es decir la formación de músicos profesionales; por otro, la presencia de la música en la educación primaria y secundaria, y más concretamente en los cursos de la ILE; finalmente - aprovechando las infraestructuras primero de la ILE, luego del Ateneo y más adelante de la Residencia y las Misiones-, la difusión musical pública, más allá del sistema educativo reglado. Naturalmente, desde dentro y fuera de la Institución contó con la ayuda de muchas otras gentes de cultura que, casi siempre de forma desinteresada, pusieron sus conocimientos sobre música al servicio de una tarea ambiciosa y muy exigente. De todas ellas, probablemente fue Eduardo Martínez Torner quien más contribuyó a la causa tras la muerte de Giner.

\section{Sobre el Real Conservatorio y la Academia de Santa Cecilia}

Podemos tomar un lugar y una fecha, Cádiz y el 1 de abril de 1875, como puntos de partida para la cruzada de Giner por una enseñanza musical profesional de calidad. Había llegado la madrugada del día 1 a la ciudad, destituido de su cátedra en la Universidad Nacional y desterrado tras el conocido como «Decreto Orovio» ${ }^{2}$. Allí recibió la visita de los krausistas

2. Manuel Orovio Echagüe, marqués de Orovio y Ministro de Fomento de Alfonso XII en 1875 elevó al rey una petición que consistía, esencialmente, en eliminar la libertad 
Alfonso Moreno Espinosa y Romualdo Álvarez Espino, y pronto comenzó a participar intensamente en la vida cultural gaditana. En una carta a Gumersindo de Azcárate hablaba de una «gran sesión musical» que se celebraba los martes y los domingos en casa de un comerciante: «suele agregarse el director del Instituto, hombre joven, culto, sumamente listo. Tocamos, por supuesto, Mozart, Haydn, Beethoven, Wagner. Tenemos quinteto de cuerda, dos pianos y armónium» (en Sopeña, 1990: 133); la cursiva es suya.

Una vez introducido en el ambiente, ese mismo año entró en contacto con los docentes de la Academia de Santa Cecilia, una floreciente escuela profesional de música donde buena parte de los enseñantes eran krausistas o simpatizantes del movimiento. Fundada en 1859, Antonio Martín la considera «una de las instituciones musicales más importantes del siglo XIX en España», y recoge una cita de su Memoria en que se afirma que, en el año 59, "ya no existía... sociedad ni establecimiento alguno donde se practicara públicamente la enseñanza de la música» (Martín Moreno, 2005: 86-87), salvo la propia Santa Cecilia, claro. El centro, pues, contaba casi veinte años de historia cuando Giner entró en su círculo, y era ya un enclave famoso de la vida musical de Cádiz.

Por lo que Giner conocía del Real Conservatorio de Madrid y otras escuelas, su deseo era principalmente ampliar la formación teórica, estética e histórica de los futuros intérpretes, cuyos estudios estaban basados en un enfoque excesivamente técnico de la música: a su juicio, el Conservatorio estaba formando solo instrumentistas, no músicos completos, y este era un grave error que debía subsanarse. Más tarde haría públicas sus críticas al centro madrileño, pero empleó su temporada en Cádiz en comprender cómo se trabajaba en Santa Cecilia y, por más que de entrada se hubiera admirado de su autonomía y calidad, también en revisar y reformar sus enseñanzas. A modo de consejero externo, colaboró en la

de cátedra en todos los niveles de la educación. Publicado como Real Decreto el 26 de febrero, y conocido como «Decreto Orovio», algunos de sus artículos establecían que «los Catedráticos de segunda enseñanza y los de la superior y profesional» debían remitir al Gobierno, «por conducto de los Rectores los programas que hayan formado o adoptado para sus respectivas asignaturas» (art. 4), o que sería el Consejo de Instrucción Pública el que se ocuparía de «los programas generales de estudios para el curso próximo, extensivos a todos los grados y órdenes de la pública enseñanza» (art. 5). Giner, que se negó a acatarlo, fue expulsado de su cátedra, desterrado a Cádiz y recluido la madrugada del 1 de abril en el castillo de Santa Catalina, aunque permaneció poco tiempo allí; gravemente enfermo de anginas, el día 15 fue trasladado al hospital, donde comenzó a mejorar. 
ampliación y mejora del programa de estudios, y animó a algunos de los maestros del centro a escribir manuales para las nuevas asignaturas. Hay cartas y registros de las actas de la Academia en los que consta el agradecimiento del claustro y la dirección por los consejos recibidos (Sánchez de Andrés, 2009: 230 ss.).

En algunos casos los manuales escritos fueron los primeros textos españoles específicos sobre la materia: allí habían enseñado o enseñaban Salvador Arpa y López (autor del Manual de Estética y Teoría del arte escrito para la enseñanza de las alumnas y alumnos del Instituto Musical de Santa Cecilia de Cádiz, de 1876), Romualdo Álvarez Espino (autor del Sumario de Historia de la Música moderna para uso de las alumnas del Real Instituto Filarmónico de Santa Cecilia, de 1883) o José Alcolea (Elementos de Acústica y Teoría física de la Música, del mismo año). Don Francisco estaba especialmente orgulloso del manual de acústica, una disciplina aún joven en el país, y que él consideraba indispensable para un conocimiento completo del hecho musical; para un esteta krausista habría sido erróneo desatender la vertiente más científica de una de las bellas artes, especialmente de una tan vinculada a la física y las matemáticas desde la Antigüedad.

En Santa Cecilia Giner encontró un clima idóneo para comenzar su labor y fortalecer sus convicciones pedagógicas. Cierto es que también tuvo que enfrentarse a la oposición de algunos padres de alumnos, y a la indiferencia o el desdén de varios estudiantes y profesores (Sánchez de Andrés, 2009: 239), pero no fue la tendencia dominante. Queda claro, en cualquier caso, que para el desarrollo de una disciplina musical sólida, tan importantes eran la cultura y las opiniones sobre música de Giner como el disponer de un círculo de eruditos que las sostuvieran y pusieran, a veces, las primeras piedras de saberes todavía lejos de afianzarse en España ${ }^{3}$.

Mientras tanto, en Madrid funcionaba regularmente el único conservatorio de la nación. Como tal, el conservatorio era una institución nacida en Italia en el siglo XVI, y no comenzó a extenderse por Europa hasta principios del XIX. En España, el primero, el actual Real Conservatorio Superior de Música de Madrid, fue fundado en 1830, y se abrió a los alumnos en enero de 1831. Algo después (1838) abrieron sus puertas

3. Giner también animó a su hermano Hermenegildo a escribir manuales de estética, y este respondió con Teoría del Arte e Historia de las Artes Bellas en la Antigüedad (1873), y un Manual de Estética y Teoría del Arte e Historia abreviada de las artes principales hasta el cristianismo (1894), obras semejantes entre sí y parecidas, asimismo, al Compendio de Estética traducido por Giner o las ideas presentadas por él en Estudios de literatura y arte. Parte de estos textos, sobre todo los de Hermenegildo, serían luego utilizados en la ILE. 
el de Barcelona y el del Teatro del Liceo (1847), en la misma ciudad; les siguen el de Valencia (1879), Oviedo (1887) y Sevilla (1888). A partir de la década de los 70 comienzan a inaugurarse más academias de música y formarse bandas de carácter civil pero, como se puede ver, todo sucedió durante el último cuarto del siglo (Gómez Amat, 1988: 259); y, en todo caso, el Real Conservatorio fue el único centro autorizado para emitir títulos oficiales de músico hasta 1905 (Sarget Ros, 2000: 127). Cuando se inauguró lo hizo con el nombre de Real Conservatorio de Música y Declamación de María Cristina, a cuyo patrocinio se debió, al menos en parte, su existencia. Era conocida la afición de la reina consorte por la música, y aunque de entrada la opinión pública recibió con alegría la apertura del Conservatorio, las críticas llegaron pronto. Como ya se ha dicho, el gusto desmesurado por lo italiano era entonces la característica más evidente y a la vez la mayor tara de la sociedad burguesa aficionada a la música en España ${ }^{4}$. La reina, napolitana de origen, había puesto al frente de la institución al cantante italiano Francesco Piermarini, cuyo programa consistía esencialmente en imitar el del conservatorio de Nápoles. Resulta natural, por ello, que fuera diana habitual de críticas y debates durante casi toda la centuria, cosa que propiciaron una sucesión de directores poco aptos o demasiado politizados y las magras ayudas que recibió de la Corona tras su aparatosa fundación.

Cuando Giner regresó a Madrid, el hombre al frente del Real era Emilio Arrieta (1823-1894), compositor — principalmente de ópera y zarzuelay antiguo profesor de composición de la misma casa. Tomó la dirección en 1868, y no la dejó hasta su muerte en el 94. Federico Sopeña dibuja un afilado retrato de su forma de operar:

Arrieta es un claro testimonio de una cierta «constante de adaptación» política en los directores del Conservatorio, desde Eslava hasta Bordas, con la muy digna y liberal excepción de Bretón. El caso de Arrieta es singular por el descaro y deja pálido aquello de «siempre con la situación» atribuido a Eslava. Protegidísimo por Isabel II, que construye para sus óperas un teatro en Palacio, le vemos en 1868 como autor de una marcha

4. Tomás Marco asevera que solamente el teatro lírico italiano o italianizante tuvo algún predicamento entre el público burgués durante el XIX, y si hubo intentos de cambiar este paradigma, chocaron contra «el baluarte de la indiferencia social impenetrable». Es más: «los raros compositores que atravesaron el muro del Teatro Real lo hicieron en circunstancias penosas y precarias y, muchas veces, al precio de traducir sus libretos al italiano» (Marco, 1989: 25). El célebre Tomás Bretón, afirma Marco, se vio obligado a presentar su ópera Los amantes de Teruel (1889) traducida al italiano y bajo el título de Gli amanti di Terolo (ibid.). 
titulada «Abajo los Borbones» [...]. Encarga muy pronto un buen retrato del Rey Amadeo y luego compone otra marcha con motivo del primer matrimonio de Alfonso XII, marcha que bien podría subtitularse «Arriba los Borbones». Navega siempre de la mano de su gran amigo Adelardo López de Ayala, con quien vive (Sopeña, 1990: 134).

Sopeña afirma, además, que Arrieta fue un claro partidario del decreto de Orovio, cosa que afecta a Giner tanto ética como personalmente. Don Francisco dejaba su postura rotundamente clara en un conocido artículo de 1878 llamado «Sobre la Institución y el Conservatorio», publicado en el diario El Pueblo Español, en el que criticaba duramente la gestión del director. Entre otras cosas, reprochaba a Arrieta que se hubiera centrado en inversiones superficiales, como la de arreglar un salón de conciertos, descuidando necesidades más acuciantes e incluso ordenadas por decreto real, como la creación de una cátedra de Estética y Literatura musical:

Acaso el Sr. Arrieta, desestimando el valor de esta clase de estudios, ¿podría creer que nada hay tan natural como el que un músico desconozca teórica y prácticamente la historia de su arte, la serie de sus grandes obras, el carácter y estilo de las diversas épocas, todo aquello que, por ejemplo, con tanta modestia y tan general aplauso, ha enseñado el Sr. Rodríguez, una de nuestras primeras ilustraciones, en la Institución Libre de Enseñanza? (OC, XV: 223).

Giner reivindica, como ya lo hiciera en Cádiz, la importancia de la estética y la teoría, y de ese equilibrio entre acción y conocimiento que se encuentra en la concepción artística de Krause. Incluso las voces más filorrománticas del momento, insiste el autor, «se afanan por reivindicar, no obstante, el valor de la reflexión y del estudio, para dar a ese fruto [la creación "pura"] suelo favorable en que pueda desarrollarse libremente» (225).

La primera parte del artículo comienza como una glosa al discurso de apertura del curso en la ILE, y es en realidad una queja explícita contra la política estatal en materia de educación. Giner habla del espíritu libre de la Institución, «al cual debe la historia intelectual del mundo sus grandes hechos y todos sus nombres ilustres», y que «no se cultiva en España hoy por hoy, para nuestra mengua, más que en un solo centro docente, en aquel donde el profesor es absolutamente libre en sus creencias y doctrinas» (220). Al colocar después de estas aseveraciones la crítica al Conservatorio, Giner estaba reforzando sus acusaciones contra Arrieta: este, como la ILE, sí tenía libertad y medios para mejorar las enseñanzas de su centro, y había elegido no hacerlo. Pero la Institución no es el único contraejemplo que propone Giner en el artículo: 
¿No siente, además, el Sr. Arrieta, que una institución privada, la Academia de Santa Cecilia en Cádiz, cuyo próspero estado (unos 700 alumnos) habrá podido pasar inadvertido al celo del Director de nuestro primer Instituto musical, se le haya anticipado desde hace tres o cuatro años a crear clases teóricas (Historia Universal, Acústica, Estética e Historia de la Música, e Historia general de las Bellas Artes), comprendiendo discretamente lo funesto de la general incultura de nuestros artistas — con cortísimas excepciones - y aspirando a remediarla por medios de tan pausado como seguro influjo?

Don Francisco, que aún consideraba que el centro matritense «más merecía el nombre de Conservatorio que el de Escuela» —en ese momento se llamaba solamente Escuela de Música y Declamación-, a causa de su inmovilismo, no olvidaba sus vínculos con Santa Cecilia, ni ocultaba el orgullo por el trabajo bien hecho.

Las demandas de Giner fueron escuchadas, pero no serían satisfechas hasta 1901, tras la muerte de Arrieta, el tránsito de dos directores fugaces y la toma de posesión del cargo por parte de Tomás Bretón, bajo cuyo liderazgo el Real comenzó a mejorar sensiblemente; célebre como operista y zarzuelista, fue uno de los más decididos a cambiar el estado de cosas en el Real. En 1894 hubo un intento serio de aplicación de las reformas propuestas por Giner, con Gabriel Rodríguez y el célebre Felipe Pedrell como adalides, pero la nueva dirección del Conservatorio - Jesús de Monasterio- y el cambio en el gobierno nacional —Cánovas subió al poder- retrasaron la reforma (Sánchez de Andrés, 2009: 248). Un nuevo cambio de gobierno, ahora con Sagasta al frente, la creación del Ministerio de Instrucción Pública y un clima general de aperturismo respecto a la innovación educativa permitieron el comienzo efectivo de una nueva etapa: Bretón fundó la cátedra de Historia y Filosofía de la Música y, además, hizo instalar la calefacción en el centro, que hasta entonces había carecido de ella.

\section{La música y la ILE}

Platón, en el libro III de la República ${ }^{5}$, es el primer pensador occidental en señalar de forma práctica y aplicada la importancia de la música en la

5. «Así los jóvenes, como si fueran habitantes de una región sana, extraerán provecho de todo, allí donde el flujo de las obras bellas excita sus ojos o sus oídos como una brisa fresca que trae salud desde lugares salubres, y desde la tierna infancia les conduce insensiblemente hacia la afinidad, la amistad y la armonía con la belleza racional [...]. La educación musical es de suma importancia a causa de que el ritmo y la armonía 
educación de los jóvenes, y lo cierto es que sus ideas cuadran, a grandes rasgos, con el discurso institucionista en el momento: desde los primeros estatutos de la ILE se implementa la presencia de la música en sus programas y, más concretamente, de la música enseñada de tal manera que su aprendizaje resulte orgánico, placentero, natural. Si Giner había denunciado la excesiva instrumentalización del aprendizaje musical en el Conservatorio, y su carencia de un arquitrabe teórico-estético que la soportara, el pecado de las enseñanzas generales de música hasta la fecha era, podríamos decir, el opuesto: un exceso de historia y teoría que no permitía al niño o al adolescente ejercitar sus capacidades musicales ni comprender de manera práctica el funcionamiento de aquello que le estaban explicando.

Hay acuerdo casi unánime en que los modos más naturales de aprendizaje musical son los que se basan en el ritmo corporal y en la voz, antes de prestar atención a los instrumentos; asimismo, las actividades en grupo resultan más estimulantes y promueven un desarrollo cognitivo más intenso que la práctica en solitario. En los programas de la ILE se contemplaban ambas cosas. Como sabemos, la Institución comenzó funcionando como una escuela de enseñanza superior, de un nivel parejo al de las universidades; más adelante veremos qué desarrollo tuvo lo musical en este periodo. En 1888, sin embargo, las enseñanzas primaria y secundaria acapararon mayor protagonismo en la Institución.

son lo que más penetra en el interior del alma y la afecta más vigorosamente, trayendo consigo la gracia, y crea gracia si la persona está debidamente educada, no si no lo está. Además, aquel que ha sido educado musicalmente como se debe es el que percibirá más agudamente las deficiencias y la falta de belleza, tanto en las obras de arte como en las naturales, ante las que su repugnancia estará justificada; alabará las cosas hermosas, regocijándose con ellas y, acogiéndolas en su alma, se nutrirá de ellas hasta convertirse en un hombre de bien. Por el contrario, reprobará las cosas feas - también justificadamente- y las odiará ya desde joven, antes de ser capaz de alcanzar la razón de las cosas; pero, al llegar a la razón, aquel que se haya educado del modo descrito le dará la bienvenida, reconociéndola como algo familiar» (República, III, 401c, d, e, y 402a). Después, Aristóteles y pensadores romanos como Cicerón o Quintiliano siguieron teniendo muy en cuenta la música en la formación de las personas y, especialmente, de los niños. Ya en el siglo X, Boecio volvió a insistir en la relevancia de la música para la configuración del espíritu, y se puede decir que desde entonces a finales del siglo XVIII es el ámbito eclesiástico el que acapara la tribuna de opinión en la materia. Si, por su parte, Platón adopta una actitud beligerante contra ciertas escalas y modos de canto o tañido, Giner, más moderado, no dejaría de criticar algunas de las músicas más nuevas, como la de Wagner, cuyos desarrollos cercanos a la atonalidad juzgaba demasiado ambiguos y confusos. 
Había dos formas complementarias en que los alumnos más jóvenes accedían a la educación musical. Por una parte, en las propias lecciones de música, que a veces impartió Giner en persona; por otra, y de modo transversal, en otras materias, de acuerdo con el sistema de aprendizaje continuo y circular favorecido por la Institución:

La ILE realizó una verdadera innovación educativa en nuestro país (siguiendo el antecedente del Colegio Internacional de Salmerón) al integrar la música como materia de la enseñanza general a todos los niveles, algo completamente novedoso en España. El hecho de que se incorporase así a los programas de enseñanza [...] y que nunca desapareciese de ellos, a pesar de las dificultades económicas de algunas etapas, demuestra que Francisco Giner y los institucionistas en conjunto consideraban la música como una materia fundamental que debía formar parte de la cultura general de cualquier hombre y de cualquier ciudadano español (Sánchez de Andrés, 2009: 256-257).

De acuerdo con estos principios de actuación, Giner de los Ríos incluía cuidadosamente referencias a la música en asignaturas como Lógica, Ética o, especialmente, Retórica y Poética — ha quedado registrado en su diario de clase y en los de sus alumnos-, por cuya integración en los programas educativos había abogado siempre. Con esta estrategia no solo se conseguía aumentar el caudal de enseñanzas musicales, un objetivo en sí mismo, sino, además, y esto es más importante, conectar sólidamente los diversos saberes. Así, de nuevo según Sánchez de Andrés, cuando terminaba de explicar los géneros literarios mayores, Giner dedicaba una lección completa a estudiar «la combinación de la poesía dramática con la música: Ópera-Zarzuela-Vaudeville-Tonadilla» (ibid.: 255). Igualmente, cuando trabajaba por las reformas en Santa Cecilia y el Real Conservatorio, Giner puso mucho énfasis en el estudio de la acústica desde el punto de vista más científico-físico, un hecho que también favorecía la cohesión entre materias educativas diversas.

Otro aspecto en que los institucionistas acertaron, como avanzábamos, fue el de insistir en la práctica de la música. Se había hecho desde los primeros tiempos de la ILE, cuando los alumnos eran de mayor edad: según Sopeña, don Francisco «tenía miedo de que apareciera la Institución sin que los que tocaran y cantaran fueran los alumnos. El conflicto estaba en no saber cantar la gente mayor y allí no había todavía niños» (1990: 139). A pesar de ello, afirma, «se cantó alrededor de un viejo armónium que había pertenecido a Don Fernando de Castro, al que se unieron las desafinaciones de aquellos señores que no habían cantado en su vida» (ibid.). 
Las actividades de conjunto coral fueron de gran importancia para que la ILE pudiera continuar con su fomento de la música. En un artículo sobre ciertas «escuelas industriales» norteamericanas —en Coloradoque proponía como modelo, el maestro describía la práctica coral en las mismas: «se reúnen para cantar, a veces, hasta varias clases, si bien en ocasiones se forma una Sección especial para atender a las necesidades del individuo o al cultivo de las aptitudes musicales que puedan tener algunos» (OC, XII: 139) ${ }^{6}$. Las actividades de canto coral, además, reforzaban el cariz igualitario de esta doctrina de enseñanza; en el mismo volumen escribía Giner:

Y no hablemos de cuanto hay que hacer en la esfera moral y en la afectiva, no menos importantes, aunque sí harto más desatendidas todavía ante el soberano despotismo del talento, que todo lo disculpa, a todo se atreve y lo puede todo. Porque si las deficiencias y lagunas de los estudios y la cultura intelectual piden remedio, no menos lo piden los vicios del sentimiento (ibid.: 82).

Es importante, además, el hecho de que todas las lecciones de Historia de la Música incluyeran audiciones que las ilustraran. Giner lo planteaba de un modo más sencillo: se trataba, simplemente, de educar a una generación en el aprendizaje activo, en el cultivo del pensamiento, «tan imperfecto en nuestra juventud, ya por desordenada sobrestima de la vivacidad y agilidad de entendimiento - uno de los mayores estímulos de perversión intelectual y moral-, ya por el hábito de la memoria mecánica y pasiva» (ibid.).

A pesar de su satisfacción por los avances en la ILE, don Francisco también había escrito, en el artículo sobre el Conservatorio: «es tan exiguo todavía el movimiento de nuestra cultura intelectual, que a nadie extrañará, probablemente, si tratamos aún de discursos e inauguraciones» (OC, XV: 217). Así, al tiempo que actuaba directamente sobre el sistema educativo, Giner logró prestar atención a otras formas más amplias de difusión de la cultura musical. Aprovechando el edificio de la propia ILE y,

6. También escribía, en el apartado sobre la música de Estudios de literatura y arte: «así, en la originaria poesía interior del ánimo, la Música de todo espíritu es polífona; consta de muchas voces: y de este modo el músico representa interiormente la vida estética mediante dos, tres, cuatro y muchas voces diferentes; sin lo cual, no podría componer sino música de una voz, y siempre de la misma voz. Interesa además esto para reconocer cuán natural y conforme a la esencia del pensamiento y del sentimiento es acompañar a una voz cantante con otras varias, y aun expresar un determinado sentimiento y estado de ánimo de un solo hombre por medio de dos, tres y más voces» (Giner, 1876: 88-89). 
más adelante, el del Ateneo de Madrid, comenzaron a celebrarse una serie de conciertos y conciertos-conferencia que dieron en llamarse «veladas musicales».

Entre 1876 y 1888, su etapa universitaria, en la ILE se celebraron muchas de estas reuniones. La asistencia de Giner era muy frecuente, y, junto con Gabriel Rodríguez, se ocupó de la organización de varias de ellas. La mayoría consistía en una suerte de conciertos didácticos o conciertos-conferencia, en los que se seleccionaba un programa determinado y se complementaba con una explicación histórico-teórica accesible al público general. De ahí, en parte, el éxito de estas veladas musicales frente al de otros ciclos de conferencias que se programaron: comenzaron a atraer gente ajena a la ILE —eran abiertas al público—, y se celebraran por la tarde o por la noche, en un horario que lo permitía. En cuanto al repertorio, sabemos que además de obras de Haydn, Mozart, Beethoven, Mendelssohn, Schumann y Chopin, hubo al menos una velada — sin duda fueron más- compuesta «toda de música española, ejecutándose el trío escrito expresamente por el maestro Chapí» (en la Crónica de la música, cit. por Sánchez de Andrés, 2009: 253); Sopeña, por su parte, menciona que se llegaron a interpretar fragmentos de Don Giovanni de Mozart, y, «uno de los días más felices del Giner músico», una reducción para piano de Las estaciones, «de su querido Haydn» (138) Giner aprovechó las veladas para promocionar la música de cámara y el lied, formas verdaderamente minoritarias por las que sentía especial cariño.

Después del 81, ya convertidas en una sólida institución, las veladas se trasladaron al Ateneo; Giner continuó asistiendo con frecuencia, casi siempre como espectador.

\section{Más allá de la ILE: la Residencia y las Misiones Pedagógicas}

Es difícil decir cuál de las empresas musicales de Giner tuvo, a la postre, mayor trascendencia, pero sin duda la vida musical de la Residencia de Estudiantes fue la más elevada, la más relacionada con el presente musical del momento, y quizá también la que más se acercó a los ideales krausistas acerca de la educación como parte integrada en la vida de los jóvenes. A pesar de que en ocasiones se exagere su esplendor, no cabe duda de que allí sucedieron grandes cosas, y el plano musical no fue una excepción; antes al contrario. Por la casa pasaron figuras extranjeras tan relevantes como Stravinski, Ravel o Poulenc, y lo mejor del panorama musical español: Óscar Esplá, Joaquín Turina y Manuel de Falla, el nombre más importante de la música nacional en el momento. Acogió conciertos, conferencias y 
reuniones musicales de todo tipo, se fundaron varios coros, y se integró todo ello con naturalidad en su vida cotidiana.

La Residencia se fundó en 1910, y desde este momento la dirigió, a petición de Giner de los Ríos, Alberto Jiménez Fraud, hasta su exilio forzoso en el 36. El ex secretario de la Junta impulsó la música en la vida de la Residencia de un modo admirable; al igual que Giner en Santa Cecilia o en las veladas de la ILE y el Ateneo, afirma Adela Presas que Fraud «no solo tenía la idea, sino la habilidad para involucrar en ella a aquellas personas que consideraba idóneas para llevarla a cabo» (2004: 65-66):

Y podemos ver cómo, pese a la intención formativa con que se plantearon las primeras sesiones y el coro de residentes, tanto la importancia de los músicos como la de los intérpretes que frecuentaban la casa, ya como residentes o como visitantes, hizo que poco a poco estos recogidos conciertos fueran adquiriendo un mayor relieve, que destacará ya nítidamente con la fundación de la Sociedad de Cursos y Conferencias y los importantes conciertos que esta patrocinó (ibid.).

Desde los primeros días de la Residencia en el n. ${ }^{\circ} 14$ de la calle Fortuny - contaba solo con diecisiete plazas-, refiere Presas, hubo un piano de media cola en el salón. Muy pronto el residente Antonio Juan Onievo, con ayuda de Eugenio d'Ors, organizó el coro en el que se cantaban canciones sencillas, esencialmente folclore; parte de ellas las armonizaría luego Martínez Torner en sus Cuarenta canciones españolas. Él mismo pasaría a dirigir el coro en 1916, aunque no está claro con qué asiduidad ensayaban o actuaban; pero el vínculo de Torner con el centro siempre fue intenso, como se evidencia en el prólogo: «el deseo de la Residencia [...] es que la lectura de sus páginas deje en el ánimo de nuestros jóvenes estudiantes un sedimento de belleza y un ansia creciente de conocimiento y amor hacia la tradición artística de nuestra patria» (1924: XV).

El músico asturiano aportó mucho a la Residencia. Compaginó con la colaboración sus labores de recopilador de folclore y su empleo en el Centro de Estudios Históricos, donde trabajó a las órdenes de Menéndez Pidal, que dirigía el Departamento de Filología. Además de la dirección del coro, Torner divulgó gran parte de su tarea en las conferencias que se celebraban asiduamente en la Residencia, en las que también participaron Menéndez Pidal, Bal y Gay y Adolfo Salazar, gran introductor de la música contemporánea en España (llegó a hablar de Schoenberg en alguna de sus charlas) ${ }^{7}$.

7. Salazar redactó muchos de los programas y guiones para los conciertos-conferencia; además, «procuraba aprovechar la visita de los músicos importantes como Ravel, Stravinski, 
Va quedando patente que en la Residencia, más allá de las iniciativas concretas, se iba generando y fortaleciendo un ambiente de aprendizaje y continuo disfrute de la música. Bal y Gay, en este sentido, decía preferir los conciertos nocturnos, y considerarlos mejores para los estudiantes, por su intimidad:

Quienes en ellos actuaban eran músicos de bien merecido prestigio, pero al mismo tiempo figuras familiares en la vida musical madrileña, de la que los residentes filarmónicos formábamos parte; así podíamos acercarnos a ellos y plantearles cuestiones musicales que nos interesaban, cosa que no habríamos osado hacer con un Ravel, un Falla o un Stravinski. Además de esos, el repertorio cultivado en aquellas sesiones íntimas estaba compuesto por la música clásica y romántica que necesitábamos como base de nuestra educación [...]. Reuniones posmeridianas, casi siempre dominicales, tenían lugar en el salón en torno al piano. Edward Wilson —que estaba traduciendo entonces las Soledades de Góngora y hoy es profesor de Español en la Universidad de Cambridge- leía conmigo a cuatro manos una gran cantidad de sinfonías y cuartetos clásicos que se guardaban en nuestra biblioteca; muchas veces, a petición de José Solís [...] me enfrentaba a Chopin; algunas tardes pasábamos de la música culta a la popular (en Pérez-Villanueva, 1990: 216).

Bal y Gay refiere, también, la presencia de Lorca y Alberti, quienes a su vez recogieron en escritos autobiográficos sus experiencias. Lorca, en particular, vivió durante largos periodos en la Residencia, y colaboró muy activamente en las conferencias: Presas Villalba habla de su «gran predilección por las canciones folklóricas, en las que mostraba lo más sabroso del pueblo». Tanto sus habituales improvisaciones en el piano del salón como sus conferencias-concierto generaban una «fascinación debida a la conjunción que en él se daba de lo culto y lo popular, arrastrando a sus compañeros a seguirle en sus viajes musicales por España». Lorca conocía los trabajos de Torner y Felipe Pedrell, pero imprimía un aire más bohemio y relajado a sus enseñanzas; memorable, según Presas, fue el concierto que ofreció junto a la cantante y bailarina La Argentinita en 1933; en 1935, cuando estos conciertos se habían trasladado a un nuevo auditorio

Poulenc, etc., para hacer un concierto en la Residencia, y si además incluía una conferencia, mejor. Se prestó atención a las diversas tendencias musicales de la época, desde la recuperación de repertorios preclásicos, hasta recitales folklóricos, o la música contemporánea, a la que se dedicaron cuatro importantes conciertos a partir de 1933, que serán una auténtica ventana abierta de novedades en el Madrid de los años treinta» (Presas, 2004: 88). 
externo, volvieron a tocar para los residentes (Presas, 2004: 74). Se recoge aun un último testimonio esclarecedor, extraído de la correspondencia de Juan Ramón Jiménez:

Por la noche, y a fin de que los alumnos, que pueden salir si quieren, no salgan, cosa difícil ya por la distancia que hay al centro, se organiza hasta las once un concierto de canto. Da gusto ver a tanto muchacho de 15 a 25 años, tan limpios, tan alegres, cantando y tocando cantos populares. Anoche, por ejemplo, no salió uno solo [...]. Además se dan conciertos todos los sábados» (2004: 69).

En conclusión: en la Residencia se logró un clima de respeto, cultura y vida intensamente artística que estaba muy cerca del ideal krausista de Giner y los demás; la presencia de la música y un enfoque lúdico-didáctico de la misma desde el principio contribuyeron en gran medida a estos logros. El crecimiento de la Residencia, tanto en tamaño como en prestigio, es parejo al crecimiento de su vida musical y al de un Madrid que iba despertando a la música de cámara, a las vanguardias europeas y a una forma diferente de escuchar y hacer música. A esto ayudó no poco que la Junta para la Ampliación de Estudios dispusiera de un fondo para que los jóvenes músicos pudieran estudiar fuera, de modo que, aparte de verdaderas avanzadas españolas en el extranjero - Falla en París—, se inició y se potenció un continuo ir y venir de influencias y novedades musicales entre las generaciones más jóvenes.

Todos estos procesos tuvieron lugar en centros de educación muy concretos, como la ILE, o en enclaves estrechamente relacionados con ellos, como la Residencia. Sin embargo, uno de los últimos esfuerzos que se hicieron antes de la guerra buscaba trascender la centralización urbana de la cultura y desplazarse a las periferias y las zonas rurales, donde el índice de analfabetismo todavía superaba el 40\%. Así, las Misiones Pedagógicas se pusieron en marcha en el 1931, bajo la dirección de Bartolomé Cossío y al amparo de la recién proclamada II República.

Tiempo atrás, en 1881, Giner de los Ríos y Cossío ya habían concebido esta idea de unas «misiones ambulantes», sin éxito en sus intentos de ponerlas en marcha; hubo alguna tentativa experimental, en la que estuvieron implicados Rafael Altamira o Cossío, pero el servicio propiamente dicho no se creó hasta el mismo año 31. La idea era sencilla: un grupo de maestros e intelectuales, remedando el modelo de las misiones eclesiásticas, se desplazaría a las zonas rurales con menor o nulo acceso a la cultura y trataría de despertar el interés del pueblo por la misma. Así, el Servicio de Bibliotecas se ocupó del fomento de la lectura, proporcionando 
bibliotecas fijas o itinerantes; la Sección de Cine y el Museo Ambulante buscarían realizar una tarea similar en sus terrenos, y el Retablo de Fantoches - títeres- y el Teatro del Pueblo otro tanto. La difusión de la música halló su lugar en esta iniciativa, desde luego, y el enlace más directo con la Residencia y el movimiento institucionista no sería otro que Martínez Torner, único director del Coro del Pueblo.

El Teatro y el Coro del Pueblo acostumbraban a viajar juntos, ya que, según Rodríguez Richart, sus componentes, unos cincuenta estudiantes de ambos sexos, eran los mismos (2009: 124). Sabemos que los implicados eran absolutamente voluntarios: «estudiantes universitarios en su mayoría, generosos e idealistas, que sacrificaban sus fines de semana y hasta parte de sus vacaciones de verano para participar en el teatro, en el coro o en otras actividades» (ibid.), chóferes que cubrían los trayectos sin cobrar y autobuses cuyo alquiler no se cobraba al Patronato, que no disponía de un presupuesto generoso. Además del Coro, en las Misiones también se puso en funcionamiento el Servicio de Música, que consistía básicamente en viajar con un gramófono y una pequeña selección de discos de pizarra, que durante un tiempo fue responsabilidad del alicantino Óscar Esplá8, mientras que Torner y Pablo de Andrés Cobos se encargaban de redactar pequeñas reseñas bibliográficas para los maestros encargados del Servicio. Los discos y el reproductor podían quedarse en los pueblos, o permanecer una corta temporada y ser luego llevados a otro lugar. Normalmente se dejaban en el colegio al cuidado de los maestros, quienes organizaban audiciones por la mañana para los niños, y por las tardes o noches para los adultos, a veces también dentro de la escuela. En cuanto al repertorio ofrecido, era de lo más variado:

Con el canto gregoriano y la lírica regional española se incluyen obras de Bach, Haendel, Mozart, Beethoven, Schubert, Mendelssohn, Weber, Chopin, Liszt, Wagner, Rossini, Berlioz, Gounod, Verdi, Franck, Brahms, Strauss, Saint-Saëns, Debussy, Mussorgsky, Borodín, Rimsky Korsakoff, Grieg, Puccini, Dukas, Ravel, Stravinski, Chapí, Bretón, Albéniz, Falla, Esplá, Turina, etc. La preferida es la zarzuela y la popular regional junto a algunas piezas sencillas de los clásicos (Canes Garrido, 1993: 156).

8. Nigel Dennis (2011: 23) comenta que en las casi performance en que consistían las sesiones del Museo del Pueblo también se ponía música clásica de fondo; «todo iba encaminado hacia el estímulo de la experiencia estética que tanta importancia tenía para Cossío». 
Qué hay tras el «etc.» de Canes no lo podemos saber, pero la lista ya parece suficiente. De esta manera, «ingenua pero eficaz», según Sopeña (144), la visión de Giner, Cossío y los demás iba tomando forma. Hasta finales de 1933 se repartieron treinta y ocho gramófonos, una cifra en realidad muy escueta, pero los municipios que el Teatro y el Coro visitaron fueron muchísimos más. Además, los maestros locales, a quienes se solía confiar el gramófono, acostumbraban a viajar a los pueblos cercanos para dejarlo prestado unos días. Era una forma precaria de acercar la música a la gente, pero era la primera y la única. Hacia el final de las misiones se habían entregado casi ochenta.

Sea como sea, y sabiendo que el presupuesto anual de 1934 para todas las Misiones, salvo el Servicio de Bibliotecas, fue de 650.000 pesetas ${ }^{9}$, comprendemos la verdadera importancia del voluntariado en esta iniciativa. María Luisa Mallo ofrece un detallado testimonio de la rutina del Coro:

Las vacaciones de Navidad, Carnaval, Semana Santa y final de curso se empleaban en giras de quince días que posibilitaran el llegar a pueblos más remotos [...], como [los de] la Alta Sanabria, los Valles del Tiétar y el Tormes, la Sierra de Béjar [...] para deleitar gratuitamente con comedias y canciones a los campesinos y serranos que, según el testimonio directo de Jesús Gallego, «oían embobados las bellezas de nuestros clásicos, pues en los pueblos precisamente donde no hay teatros, es donde con más entusiasmo se escuchan las representaciones teatrales [...] y todo esto era obra de Torner y de Casona, asturianos a $[\mathrm{m}]$ bos hasta los tuétanos, a quienes algún día se hará justicia, honrándoles como se merecen (Mallo, 1980: 70).

A pesar de su lugar central en el Coro, durante los últimos años de la República los cargos de Torner se multiplicaron, aunque siguió dirigiéndolo y coordinando el Servicio de Música hasta al menos 1936. En 1932 entra como profesor en el Conservatorio, en la cátedra de Prácticas del Folclore, y también en la ILE, y en 1934 pasaría a formar parte de la Junta de Música. Tengamos en cuenta, para terminar, que Torner no solo se encargaba de seleccionar los materiales del coro y dirigirlo en las Misiones: también debía ensayar regularmente con los integrantes en Madrid, en la Escuela Normal del Paseo de la Castellana. Mallo habla de una labor verdaderamente «ingrata», "pues muchos de los estudiantes que componían los coros no tenían apenas conocimientos de solfeo» (Mallo, 1980:

9. En los años anteriores, desde 1931, los presupuestos habían sido de 300.000, 525.000 y 700.000 pesetas, respectivamente (Canes, 1993: 155). 
73). Como Torner siempre quiso que la música antigua española estuviera presente, tenía que realizar verdaderos esfuerzos para montar las obras de hasta seis voces de Tomás Luis de Victoria, Juan del Enzina o Antonio de Cabezón; toda esta febril actividad recuerda mucho el modo gineriano de desenvolverse. Torner, además, aún pudo sacar otro provecho para su propia actividad investigadora: «insisto en que la mejor música iba en dos direcciones: la que se escogía durante las excursiones, la que luego identificaba Torner y la que se incorporaba al teatro» (Sopeña, 1990: 144).

Dadas las limitaciones mencionadas, es evidente que tanto el Servicio de Música como el Coro del pueblo podían sentirse más satisfechos por la tarea que estaban realizando que por los resultados obtenidos, en términos absolutos. En episodios como el de la Misión de Sanabria, que relata Canes, en el que los maestros llegaron a una zona absolutamente miserable, con la población desnutrida y enferma (Canes Garrido, 1993: 160 ss.), quedaba claro que la nación estaba aquejada de problemas más graves que la incultura o el analfabetismo. Ello no restaba sentido a los esfuerzos de gentes como Torner o Casona, pero los dotaba de un matiz distinto, una realidad que quedó patente cuando se agudizó el clima prebélico, e incluso después del estallido de la guerra: entonces entidades como las Misiones o la Residencia devinieron símbolos, más allá de sus modestas actividades: eran vistas a la vez como dignos ejemplos de lo que los sublevados pretendían destruir, y como baluartes de resistencia frente a la barbarie. Un ejemplo: en el número 453 (19 de noviembre de 1936) del magacín gráfico Estampa, reconvertido en publicación de propaganda republicana tras el golpe, aparece un reportaje patriótico de Eduardo de Ontañón llamado «Las misiones pedagógicas, consuelo de heridos de guerra» (pp. 11-13). En él se narra, acompañada de muchas imágenes, una función del Teatro y Coro en un hospital de heridos del frente, donde el entusiasmo y la camaradería embargan a asistentes, voluntarios y profesores. Cuando el coro comienza a cantar jotas, tonadas y otras piezas regionales «al final, todos aplauden con igual contento, porque la voz popular les ha llegado por igual y les ha hecho despertar la dulce añoranza del paisaje nato que todos llevamos dormido dentro» (13).

El fin de todas estas iniciativas estaba ya cerca. Tras la sublevación de julio, Torner siguió trabajando en su investigación, y lo hizo, con pequeñas interrupciones, hasta que pasó a Francia en 1939, tras la caída del frente de Tarragona. Las interrupciones consistieron sobre todo en traslados: el asturiano y su familia se fueron desplazando con el Gobierno de la nación, según las sucesivas derrotas obligaban a este a cambiar de 
sede. Así, Torner marchó a Valencia ese mismo verano, en un coche del Ministerio de Instrucción Pública, llevándose buena parte de su archivo personal, y luego a Barcelona en octubre del 37, dejando esta vez gran parte del archivo tras de sí. En ambas ciudades continuó trabajando y publicando (González Cobas, 2002: 164 ss.). Las primeras semanas en Francia fueron verdaderamente traumáticas, y acabaron con Torner hospitalizado, enfermo de disentería, cerca del campo de refugiados de Argelés, de donde el Comité Inglés de Ayuda a los Refugiados Españoles lo había sacado. Su hijo mayor, Eduardo, había sido enviado a un lejano pueblo de Normandía.

Torner pasó el resto de su vida en Londres, donde mucho más adelante (1947) su familia se reunió con él. Según González Cobas, aunque fue muy bien considerado, «sin duda de ninguna clase, Torner nunca fue feliz aquí» (2002: 167). Trabajó para la BBC, dio conferencias, clases, musicó radiodifusiones de obras de Lorca, y en general continuó avanzando en el campo del folclore y la música tradicional española, publicando numerosas obras de diversa envergadura. Nunca regresó a España. Ampliamente reconocido, pero pobre, hubo de contar a menudo con la ayuda de otros exiliados mejor situados, y murió en 1955, en un hospital de beneficencia. La última actuación del Teatro y Coro del Pueblo había tenido lugar casi veinte años atrás, en julio del 36, en el madrileño Hospital de Sangre Giner de los Ríos.

\section{Coda}

En el fondo, en todos los campos en que tuvo alguna influencia, esta reforma heterogénea musical siguió una estrategia muy similar: ampliar las estructuras de conocimiento y difusión musical más allá de sus límites establecidos. En el Conservatorio, donde la música se enseñaba cada vez más como un arte mecánico, la reforma consistió en proveer a los músicos de la base estética e histórica que les era escamoteada. En las enseñanzas primarias y secundarias se introdujo la música transversalmente en casi todas las otras asignaturas, y también en la vida de la comunidad educativa en general, a través del coro y las veladas. Otro coro, el de la Residencia, sirvió para estrechar lazos entre los internos, mientras que la variedad $\mathrm{y}$ el atractivo de sus sesiones musicales permitieron que los alumnos «que pueden salir, si quieren, no salgan», como se congratulaba Juan Ramón. Mediante la música - y otras actividades-, un pequeño albergue de estudiantes de las afueras acabó siendo uno de los centros culturales más atractivos de la Edad de Plata. En cuanto a las Misiones, sencillamente 
llevaron la música allá donde apenas la había, y por mediación de Torner y otros revalorizaron tradiciones que se iban perdiendo en las periferias del país y de la cultura dominante.

Ya se ha insistido en el carácter colectivo de cada una de estas iniciativas, pero es indiscutible que, en última instancia, todas son producto de aquel andar resuelto y enérgico que comenzaron Giner de los Ríos y los suyos en los años 60 del siglo XIX. Resulta inevitable, desde nuestra posición actual, cuestionarse el estado de cosas en lo tocante a la pedagogía y la cultura musicales, y visualizar estos ciento cincuenta años como una progresión lineal. Las variables son numerosísimas, las circunstancias socioeconómicas muy diferentes, y es cierto que a menudo un velo arcádico suele distorsionar nuestra visión del periodo que se dio en llamar Edad de Plata. Pero, con todo, probablemente parte de lo que quiso hacer Giner en materia de música debería por fin ser realizado, y parte de lo que logró hacer, repetido.

\section{Bibliografía citada}

CANES GARRIDO, Francisco, «Las Misiones Pedagógicas: educación y tiempo libre en la Segunda República», Revista Complutense de Educación, 4, 1 (1993), pp. 147-168.

DenNis, Nigel, «Ramón Gaya y el Museo del Pueblo de la Misiones Pedagógicas», Escritura e Imagen, 7 (2011), pp. 15-26.

Estampa. Revista Gráfica y Literaria de la Actualidad Española y Mundial [Madrid], 453 (1936).

GINER DE LOS Ríos, Francisco, Estudios de literatura y arte, Madrid, Librería de Victoriano Suárez, 1876.

- Obras completas, VII: Estudios sobre educación, Madrid, Espasa-Calpe, 1935.

- Obras completas, XV: Estudios sobre las artes industriales y Cartas literarias, Madrid, Espasa-Calpe, 1926.

- Obras completas, XVI: Ensayos menores sobre educación y enseñanza, Madrid, Espasa-Calpe, 1927.

Gómez Amat, Carlos, Historia de la música española. 5. Siglo XIX, Madrid, Alianza, 1988.

GONZÁlez COBAS, Modesto, «El discreto exilio del musicólogo Eduardo Martínez Torner», en A. Fernández Insuela (ed.), Sesenta años después: el exilio literario asturiano de 1939 (Actas del Congreso Internacional celebrado en la Universidad de Oviedo), Oviedo, Universidad de Oviedo, 2000; <http://www.cervantesvirtual.com/nd/ark:/59851/bmcqz276> [consulta: 10 julio 2015]. 
KRAUSE, Karl Christian Friedrich, Compendio de Estética, traducido del alemán y anotado por Francisco Giner, Sevilla, Imprenta Girondés y Orduña, 1874; 2. edición ampliada con la Teoría de la música, Madrid, Librería de V. Suárez, 1883.

- Compendio de Estética, traducido del alemán y anotado por Francisco Giner, ed. Pedro Aullón de Haro, Madrid, Vérbum, 2009.

MALlo DEl CAMPO, María Luisa, Torner. Más allá del folklore, Oviedo, Universidad de Oviedo, 1980.

MARCO, Tomás, Historia de la música española. 6. Siglo XX, Madrid, Alianza, 1989.

MARTín Moreno, Antonio, «La enseñanza musical en España en el siglo XIX: el Curso completo de música de la Escuela Normal de Zaragoza (1861) y la Historia de la música de la Academia Santa Cecilia de Cádiz (1883)», Publicaciones. Facultad de Educación y Humanidades de Melilla, 35 (2005), pp. 75-108; <http://revistaseug.ugr.es/index.php/publicaciones/article/view/2293/2411> [consulta: 10 julio 2015].

MARTínez TORnER, Eduardo, Cuarenta canciones españolas, Madrid, Publicaciones de la Residencia de Estudiantes, 1924.

Ossa Martínez, Marco Antonio de la, La música en la guerra civil española, Cuenca, Universidad de Castilla-La Mancha, 2011.

PÉreZ-VillanueVa Tovar, Isabel, La Residencia de Estudiantes, Madrid, Ministerio de Educación y Ciencia, 1990.

Platón, República, ed. Conrado Eggers Lan, Madrid, Gredos, 2007.

Pliego DE ANDRÉS, Víctor, «El Servicio de Música: Eduardo Martínez Torner y Pablo de Andrés Cobos», catálogo de la exposición Las Misiones Pedagógicas, 1931-1936, Madrid, Sociedad Estatal de Conmemoraciones Culturales y Residencia de Estudiantes, 2006, pp. 414-443.

Presas Villalba, Adela, «La Residencia de Estudiantes (1910-1936): actividades musicales», Música. Revista del RCSMM, 10-11 (2003-2004), Madrid, Real Conservatorio de Música de Madrid, 2004, pp. 55-103.

RODRÍGUEZ RICHART, José, Dos patrias en el corazón. Estudios sobre literatura española en el exilio, Madrid, Vérbum, 2009.

SÁNCHEZ DE ANDRÉS, Leticia, «El pensamiento y la actividad musical de Francisco Giner de los Ríos. Iniciativas krausoinstitucionistas en el ámbito de la educación musical (1869-1915)», en José Manuel Vázquez Romero (ed.), Francisco Giner de los Ríos: actualidad de un pensador krausista, Madrid, Marcial Pons, 2009, pp. 199-258.

- «Manuales de origen krausista para la enseñanza de la estética y la historia del arte y de la música en los institutos de bachillerato», Revista Arbor. Ciencia, Pensamiento y Cultura, 187-749 (2011), pp. 535-545; <http://arbor.revistas. csic.es/index.php/arbor/article/viewFile/1324/1333> [consulta: 10 julio 2015]. 
SARGET ROS, M. ${ }^{a}$ Ángeles, «Perspectiva histórica de la educación musical», Ensayos: Revista de la Facultad de Educación de Albacete, 15 (2000), pp. $117-130$.

SOPEÑa IbáÑEZ, Federico, «La Institución Libre de Enseñanza y la música», Música. Revista del RCSMM, 1 (1994), pp. 125-146.

Fecha de recepción: 13-8-2015

Fecha de aceptación: 4-12-2015 



\title{
GINER DE LOS RÍOS, CRÍTICO LITERARIO
}

\author{
JOAQUÍN JUAN PENALVA \\ Universidad Miguel Hernández (Elche)
}

\section{Resumen}

El artículo ofrece un repaso por las principales aportaciones de Francisco Giner de los Ríos en el ámbito de la crítica, la historia y la estética literarias, tarea que desempeñó fundamentalmente en la Revista Meridional de Granada entre 1862 y 1863 y en algunos periódicos de Madrid. Esos trabajos, sumados a otros posteriores, conformaron su primer libro, Estudios literarios (1866), que tuvo una segunda edición ampliada en 1876, con el título de Estudios de literatura y artes. Después de 1876, Giner de los Ríos abandonó los estudios literarios, aunque regresó a ellos poco después, cuando publicó sus «Cartas literarias» en El Pueblo Español. Esta nueva serie de textos apareció a finales de 1878 y principios de 1879, y suponen su última aportación a la crítica literaria. Entre los autores de los que se ocupa, destacan Ventura Ruiz Aguilera, a quien le dedica cuatro artículos, y Benito Pérez Galdós.

Palabras clave: Francisco Giner de los Ríos; crítica literaria; historia literaria; estética literaria.

\begin{abstract}
This paper presents a review of the main contributions that Francisco Giner de los Ríos made in the field of literary criticism, history and aesthetics, which he mainly carried out in the Revista Meridional of Granada between 1862 and 1863, and later in some newspapers from Madrid. All these works and some he wrote afterwards were compiled in Estudios literarios (1866), his first published book, which had an extended edition in 1876, Estudios de literatura y artes. After 1876, Giner de los Ríos left the field of literary studies, but he came back soon, when he published «Cartas literarias» at El Pueblo Español. These new writings appeared at the end of 1878 and beginning of 1879 , and they were Giner's last contribution to the literary criticism. Among the authors he wrote about, we can emphasize Ventura Ruiz Aguilera (Giner wrote four articles about him) and Benito Pérez Galdós.
\end{abstract}

Keywords: Francisco Giner de los Ríos; literary criticism; literary history; literary aesthetics.

Anales, 27 (2015), pp. 131-138

DOI: 10.14198/ALEUA.2015.27.07 
Aunque hoy en día es más recordado como uno de los fundadores de la Institución Libre de Enseñanza, Francisco Giner de los Ríos también ejerció, durante algunas etapas de su vida, de crítico literario. Publicó sus primeros artículos en Granada, en cuya universidad estudiaba desde 1853, concretamente en la Revista Meridional, en la que escribió fundamentalmente sobre política y literatura. Giner nunca formuló un sistema filosófico propio, pero su vida fue ejemplo de cuanto creía y defendía — no en vano los profesores krausistas eran considerados textos vivos-. En sus primeros años en Madrid, lugar al que se trasladó en 1863, conoció a Gumersindo de Azcárate, con quien inició varias empresas. El verdadero maestro de Giner fue Julián Sanz del Río, importador de la filosofía krausista, a quien le unió una estrecha relación entre 1863 y 1869.

Giner de los Ríos fue un autor muy polifacético. Valorado fundamentalmente por su labor como pedagogo y guía de hombres, caló hondo en todos sus discípulos, que lo consideraron, más que un escritor o un filósofo, un conversador y un amigo. El testimonio de quienes lo conocieron, si bien es fundamental, fue siempre encomiástico y admirativo, lo que, en ocasiones, ha impedido una aproximación objetiva a su obra escrita, que según esos mismos seguidores es tan solo un tímido reflejo de las ideas del maestro. No necesita Giner de tal cautela, pues su producción, variada y extensa, se defiende por sí sola. Otra cosa es que no podamos valorar en su justo término su importancia como texto vivo, pues de esa faceta suya solo contamos con las apreciaciones de quienes tanto le quisieron.

Además de pedagogo, Giner fue también filósofo, sociólogo y jurista, pero sus escritos no se circunscribieron únicamente a esas disciplinas, sino que abordaron también la crítica e historia literarias, el arte, la rejería, la tapicería, el mobiliario y las custodias de las iglesias, entre otros muchos y pintorescos temas. Tradujo la obra de algunos autores extranjeros, sobre todo filósofos, entre los que podemos destacar a Krause, Leonhardi, Ahrens, Roeder, Falckenberh y Compayré. A lo largo de toda su vida colaboró en diversas publicaciones periódicas como Revista General de Legislación y Jurisprudencia, El Reino, Revista Meridional, Revista Popular, Ilustración Artística, La Lectura, La España Moderna, El Pueblo Español, Revista Mensual de Filosofía, Literatura y Ciencias de Sevilla, Revista de Educación, Revista de España... Además, contribuyó a la creación de dos nuevas tribunas, en este caso científicas: el Boletín-Revista de la Universidad de Madrid y el Boletín de la Institución Libre de Enseñanza.

La fundación de la Institución Libre de Enseñanza supuso un hito en su trayectoria intelectual, según reconocen todos los estudiosos de la 
figura de Giner. Así, a partir de 1876 sus escritos se orientaron fundamental, aunque no exclusivamente, hacia la pedagogía. Ahora bien, los primeros artículos publicados por Giner versaron sobre crítica, historia y estética literarias, y aparecieron en la Revista Meridional de Granada. Esos trabajos, sumados a algunos posteriores, conformaron el volumen Estudios literarios (1866), a la sazón, su primer libro publicado, que tuvo una segunda edición ampliada en 1876, con el título de Estudios de literatura $y$ artes.

Desde 1868 centró gran parte de sus esfuerzos en estudios de carácter filosófico y jurídico, relacionados con su cátedra de Filosofía del Derecho y Derecho Internacional. De esta época son sus libros Introducción a la filosofía del derecho (1869), Enciclopedia del derecho (1870), Principios elementales del derecho (1871), Lecciones sumarias de psicología (1874) y Estudios filosóficos y religiosos (1876).

En 1880, Giner pronunció el discurso de apertura de curso en la ILE, publicado con el título de El espíritu de la educación en la Institución Libre de Enseñanza. A partir de ese momento, el tema de la pedagogía, que ya había estado presente en algunos de sus libros de la década anterior, cobró una importancia fundamental: La futura ley de Instrucción Pública (1869), Los estudios de facultad (1870), Instrucción y educación (1879), Enseñanza y educación (1881), La enseñanza confesional y la escuela (1882), Campos escolares (1884), Las reformas del señor Pidal en la enseñanza de las maestras (1885), Estudios sobre educación (1886), El espíritu mecánico en la educación (1887) y Educación y enseñanza (1889).

Giner fue colaborador habitual de la Revista de Derecho y Sociología, que comenzó su andadura en 1895. Durante esos años, coincidiendo con el primer lustro de la revista, proliferaron sus trabajos de índole sociológica, reunidos en los volúmenes Las personas sociales en la ética de Wundt (1895), El estado de la persona social (1896), La ciencia como función social (1898) y Estudios y fragmentos sobre la teoría de la persona social (1899). Este interés por la sociología no empañó, sin embargo, su constante preocupación por la pedagogía, asunto central de La enseñanza individual en la escuela (1895), Grados naturales en la educación (1897) y Sobre la enseñanza de la filosofía (1898). De hecho, en la última etapa de su vida Giner se ocupó exclusivamente de esa disciplina en El problema de la educación nacional y las clases "productoras» (1900), Pedagogía correccional (1900), La escuela que «cerrará presidios» (1901) y Pedagogía universitaria (1905).

Los escritos sobre literatura de Giner, pues, se circunscriben al momento de su formación intelectual, cuando más directamente recibe la 
influencia de la filosofía alemana. Reunidos, según se ha dicho, en 1866 (Estudios literarios) y 1876 (Estudios de literatura y artes), casi todos los publicó antes en la Revista Meridional de Granada entre 1862 y 1863, y algunos en periódicos de la corte. El propio autor, en el prólogo al volumen de 1866, indicaba que,

escritos en su mayor parte poco después de los veinte años, edad en que no es dado a la medianía producir sazonados frutos, deben considerarse tan solo como hijos de ese afán que el espíritu siente por representarse sus propias ideas e impresiones, según los acontecimientos de la vida van solicitando su atención y promoviendo en él un cúmulo de reflexiones desordenadas e incompletas (5).

Todos estos trabajos fueron reunidos por Manuel Bartolomé Cossío, su más fiel discípulo, en 1919, en el tomo tercero de las Obras completas de su maestro. Giner consideraba que la literatura de su época se encontraba en crisis, tal como explicó en numerosos textos, entre ellos en el prólogo de 1876, donde hablaba en términos de crisis general de las artes:

El Arte presente es el Arte de la vulgaridad. El drama desciende a una conversación discreta; la ópera, a un espectáculo de física recreativa; la lírica, al álbum de las damas; la pintura, al figurín y al almacén de antigüedades: todo ello, en suma, a fútil pasatiempo, a mero adorno secundario de otras más imperiosas necesidades (XII).

También se ocupó Giner de la historia literaria y de la estética, sobre todo en «El arte y las artes» (1871) y «¿Qué es lo cómico?» (1872). En estética, Giner sigue a Krause y considera que la belleza se identifica con la idea de verdad, bien y Dios. Como resulta habitual en muchos pensadores de formación alemana, las ideas ginerianas destilan cierta galofobia.

Uno de sus artículos más interesantes es «Del género de poesía más propio de nuestro siglo», donde se refiere a la crisis de la literatura, de la que tan solo se escapa la lírica, pues el poeta, «reconcentrado en la expresión artística de los sentimientos que encuentra en su alma, apenas nos ilustra indirectamente acerca de la sociedad a que corresponde, y es un guía menos precioso que los de aquellos otros géneros para el estudio de los tiempos pasados (1876: 63).

Así, aunque considera que la epopeya es la más perfecta de las manifestaciones de la épica —en «De la poesía épica, y en particular, de la epopeya» (1864)—, ya que «[n]o se limita a una esfera particular del mundo que tiene ante sus ojos, sino a todas» (1876: 72), reconoce que a finales del siglo XIX no se dan las condiciones necesarias para su aparición. En 
«Poesía erudita y poesía vulgar» (1863), Giner entra de lleno en la dicotomía clásicos-románticos, tema fundamental de un trabajo más extenso de ese mismo año: «Dos reacciones literarias (clásicos y románticos)». En ambos se cargan las tintas sobre los aspectos negativos del neoclasicismo francés, que abominó de la propia tradición medieval y optó por modelos ajenos.

El artículo más interesante del volumen es «Consideraciones sobre el desarrollo de la literatura moderna» (1862), donde se presenta un complejo panorama de la evolución de la literatura a partir de la Edad Media. Se trata de una literatura lastrada fundamentalmente por el exceso de sentimentalismo, realismo e individualismo, «extravíos» que se propagaron fundamentalmente en Francia. Según Giner, uno de los casos más nocivos de la influencia de la literatura francesa sobre la española fue la del romanticismo español, que «no expresa el progreso de nuestros antecedentes nacionales; sino, con notables excepciones, la continuación, naturalmente algo degenerada, del neo-romanticismo francés» (1876: 230). Para Giner, toda creación artística que aspire a permanecer en la historia «debe por un lado, referirse a las leyes necesarias de lo bello; por otro, al carácter de la civilización en que nace: lo inmutable y lo temporal, lo accidental y lo absoluto han de tener en ella representación» (1876: 241).

Junto a estos trabajos de índole histórica y teórica, también se incluyó en este volumen una serie de reseñas. La primera, «Una dolora en prosa» (1865), es un comentario de Lo absoluto, de Ramón de Campoamor. Elogia Giner el propósito divulgativo del libro, que se sitúa dentro de la corriente idealista, y lo califica de poema didáctico, «aquel noble género que aspira a representar sensiblemente la belleza de las ideas y los sentimientos que su contemplación interior despierta en el espíritu del hombre» (1876: 259).

Hasta cuatro artículos llegó a dedicarle Giner de los Ríos, entre 1862 y 1867, a los libros de poemas de su amigo Ventura Ruiz Aguilera. Se detiene especialmente en Elegías, donde Ruiz Aguilera pretendió atrapar la memoria de la hija muerta, y no tanto en Armonías y Cantares, Proverbios ejemplares y La Arcadia moderna: Églogas e Idilios realistas y Epigramas. En todos ellos, Giner elogia desmesuradamente la obra de su amigo, hasta el extremo de afirmar que su poesía debería recitarse en las plazas públicas.

Aparecen también en este volumen dos notas dedicadas a sendos estudios sobre el Quijote: La Estafeta de Urganda o Aviso de Cid Asam-Ouzad Benengeli sobre el desencanto del Quijote, de Nicolás Díaz de Benjumea, y El Quijote y la Estafeta de Urganda, de Francisco María Tubino. En ambos casos, Giner subraya la multiplicidad de lecturas de la novela de Cervantes, 
que trasciende la crítica o parodia de los libros de caballerías. Díaz de Benjumea, en palabras de Giner, aboga por la «identidad entre el mismo Cervantes y su héroe, considerando las aventuras de este como el trasunto alegórico de la infortunada vida del príncipe de nuestros ingenios» (1876: 301), mientras que Tubino cree que «la novela de Cervantes no es directamente sino una crítica literaria, por más que, en forma mediata, contenga otros sentidos diversos, germinación espontánea del genio de su autor» (1876: 307).

La última reseña incluida en Estudios de literatura y artes es la titulada «Un novelista español» (1871), que se centra en La Fontana de Oro, la primera novela de Benito Pérez Galdós. Giner la considera interesante porque se refiere «a un período tan memorable en nuestra historia contemporánea como el del 20 al 23, ofreciendo un animado cuadro de la vida y cultura que por entonces ofrecía esa postrada sociedad, a trechos galvanizada por los sacudimientos políticos» (1876: 313). Alaba sobre todo la creación del personaje de Clara y el sello castizo de que está impregnada toda la obra.

Después de 1876, Giner de los Ríos abandonó los estudios literarios, a los que regresó poco después, cuando publicó sus «Cartas literarias» en El Pueblo Español. Esta nueva serie de textos apareció a finales de 1878 y principios de 1879, y suponen su última aportación a la crítica literaria. Esas «cartas» fueron recogidas, junto a los Estudios sobre artes industriales (1892), en el volumen XV de sus Obras completas, publicado en 1926, y se pueden dividir en dos grupos. El primero lo conforman «Sobre el discurso de apertura de la Universidad», «Sobre la Institución y el Conservatorio», «Sobre publicaciones de Historia», «El Ateneo de Madrid y el Sr. Moreno Nieto», «Sobre la Sociedad de Bibliófilos» y «La "Biblioteca de Autores Aragoneses"». Los títulos de los artículos son bastante descriptivos y no hace falta entrar en más detalles. El segundo grupo incluiría los estudios y reseñas propiamente literarios.

El primer trabajo de esta índole es «Poesías de Flores Arenas», donde Giner recorre brevemente la producción lírica y dramática de este autor, a propósito de la aparición de sus Obras escogidas, publicadas por la Real Academia Gaditana de Ciencias y Letras en edición no venal. En «Sobre La familia de León Roch» vuelve a la novelística de Pérez Galdós y subraya la superioridad de los personajes femeninos sobre los masculinos, una idea que ha asumido unánimemente la crítica posterior. La considera una novela de tesis, pues «está toda ella subordinada a un fin moral: mostrar cómo en España la religión, el principio mismo del amor y concordia entre los hombres, se convierte hoy en potencia diabólica de perversidad y de 
odio» (1926: 287). Además, ataca la caracterización del personaje principal, así como la sensación de "galería de retratos» (1926: 289) que se desprende de toda la obra. Más general es su trabajo «Sobre publicaciones extranjeras», un breve pero completo recorrido por las novedades editoriales que habían ido apareciendo en toda Europa a lo largo de 1878. En «Sobre el teatro» se ocupa de las causas que han motivado la crisis del género dramático en España, agravada por la ausencia de grandes intérpretes, capaces de dignificar con su trabajo producciones mediocres, y por la práctica inexistencia de la figura del director de teatro, encargado de elegir las obras de acuerdo con un programa que atienda a criterios estéticos y ofrezca suficiente variedad en sus contenidos. La última de las «cartas literarias» publicadas en El Pueblo Español se titula «Sobre el libro de González Serrano Goethe», donde Giner, con ocasión del lanzamiento de dicho volumen, aprovecha para regresar a uno de sus autores alemanes predilectos.

Tras este paréntesis, Giner volvió a sus quehaceres habituales y redujo ya definitivamente sus opiniones literarias al ámbito privado de conversaciones y correspondencia. Así, en carta a Clarín de 18 de agosto de 1891, confesaba no estar al día en cuanto a novedades editoriales. Había leído Su único hijo y le elogiaba a su autor la «nota amarga, pesimista, humana» (1965: 113) de la novela. No obstante, Giner consideraba que el género se encontraba en crisis, a la que había contribuido en buena medida la tendencia naturalista: «Nunca he visto como hoy tanta y tan elevada idealidad, y al par tanto rebuscamiento, mezclado con ella, de fotografiar el lado desagradable, animal y grosero de la vida» (1965: 113). Entre la correspondencia de Giner se conservan también dos breves notas dirigidas a Azorín, que le había enviado sendos ejemplares de España y de Lecturas Españolas (1965: 122-123).

Sin duda, el mejor trabajo sobre la crítica literaria gineriana es «Las ideas literarias de Francisco Giner de los Ríos», de Juan López-Morillas. Allí se afirma que el ideal de arte de Giner pasa por la «entrañada conexión entre lo esencial y lo formal» (López-Morillas, 1966: 36). El arte sería, por tanto, «la suprema actividad humana» (1966: 37) y la literatura un elemento fundamental para reconstruir la historia íntima o interna de los pueblos. Pero eso no actúa en detrimento del valor estético propio de la obra literaria, que ha de aunar el fin estético con el fin moral. Según López-Morillas, Giner aspiraba a tres fines: «a) mostrar que la cultura francesa es nociva para la española; $b$ ) alentar el estudio crítico del pasado literario español como inmejorable remedio contra la manía de imitar; y c) 
instar al literato a ser fiel a su espíritu y a su tiempo» (1966: 48). Estos tres objetivos tenían como meta la resolución de la crisis de las letras españolas de acuerdo con el carácter optimista que caracterizaba al pensamiento krausista. Para Giner, la crítica literaria se encontraba en estrecha relación con la filosofía, y el fin de ambas tendría carácter ético.

Más recientemente, Adolfo Sotelo Vázquez se ha ocupado del mismo tema en el artículo «Las ideas literarias de don Francisco Giner de los Ríos» (2002), si bien se centra fundamentalmente en las opiniones de Francisco Giner de los Ríos sobre la novelística de Galdós y su relación con las de otros críticos de la época.

Lo cierto es que, desde su perspectiva idealista, Giner diagnosticó muchos de los males de la literatura moderna y analizó con solvencia unas cuantas obras, si bien, como apuntaba ya López-Morillas en su momento, «el interés de Giner por la literatura, no obstante ser profundo, queda siempre subordinado a su interés por la filosofía, entendida esta en el doble sentido de hermenéutica histórica y de propedéutica de una vida humana plena y armónica» (1966: 55).

\section{Bibliografía citada}

GINER DE LOS Ríos, F, Estudios literarios, Madrid, Imprenta de R. Labajos, 1866.

- Estudios de literatura y artes, Madrid, J. M. Pérez, 1876.

- Obras completas de D. Francisco Giner de los Ríos. XV. Estudios sobre artes industriales y Cartas literarias, Madrid, La Lectura, 1926.

- Ensayos y cartas: Edición de homenaje en el cincuentenario de su muerte, México, Fondo de Cultura Económica, 1965.

- Ensayos, ed. Juan López-Morillas, Madrid, Alianza, 1969.

LÓPEZ-Morillas, J., «Las ideas literarias de Francisco Giner de los Ríos», Revista de Occidente, año IV, 2. ${ }^{a}$ época, 34 (1966), pp. 32-57.

Sotelo VÁzQuez, A., «Las ideas literarias de don Francisco Giner de los Ríos», en La elaboración del canon en la literatura española del siglo XIX, Barcelona, Universitat de Barcelona, 2002, pp. 407-414.

Fecha de recepción: 17-11-2015

Fecha de aceptación: 24-11-2015 


\title{
LA COMPETENCIA DE LA RAZÓN PRÁCTICA EN LA CONFORMACIÓN DEL HUMANISMO GINERIANO ${ }^{1}$
}

\author{
Delia MANZANERO \\ Universidad Rey Juan Carlos de Madrid
}

\section{Resumen}

En este artículo, sustentamos que el conocimiento de las construcciones teóricas del siglo XVI puede resultar muy útil con vistas a la conformación de la filosofía jurídica gineriana y los esquemas de organización social de los siglos XIX y XX. Ciertamente no se trata de trasladar sin más con una conciencia anacrónica, como en alguna ocasión se ha pretendido, aquellos esquemas al presente, pues el solo establecimiento de algunas analogías no es suficiente para difuminar una distancia de tres siglos. En cualquier caso, creemos que un estudio detenido de estos esfuerzos históricos por revitalizar principios jurídicos y sociales como el de razón práctica, puede ser de gran utilidad para comprender el contexto en que se fraguó la filosofía jurídica de Francisco Giner y su amplificación y extensión durante la Edad de Plata española. Al mismo tiempo, creemos que su estudio posee el relevante interés de entrañar una posible lectura de los clásicos iusnaturalistas hispanos desde y para la cultura filosófico-jurídica contemporánea, por lo que también dedicaremos algunas líneas a este tema.

Palabras clave: Francisco Giner de los Ríos; razón práctica; iusnaturalismo; derecho.

\begin{abstract}
In this article, I support the fact that knowing the theoretical constructs of the sixteenth century can be very useful for shaping Giner's legal philosophy and the social organisation systems of the nineteenth and twentieth centuries. This is certainly

1. Esta investigación se realiza en el marco del proyecto de investigación «Fundamentos y desarrollo de la idea krausista de Europa: universalismo, internacionalismo, educación y cultura» (I+D+i: FFI2011-23682, 2012-2015) de la Universidad Pontificia Comillas, dirigido por Ricardo Pinilla Burgos y financiado por el Ministerio de Economía y Competitividad. Asimismo, esta investigación se inscribe dentro de una Ayuda Juan de la Cierva - Formación Posdoctoral adscrita a la Universidad Rey Juan Carlos de Madrid y financiada por el Ministerio de Economía y Competitividad (FPDI-2013-17242).
\end{abstract}

Anales, 27 (2015), pp. 139-157

DOI: 10.14198/ALEUA.2015.27.08 
not a question of simply transferring those systems to the present time with an anachronistic consciousness, as it has on some occasion been intended, for the mere establishment of some analogies is not enough to blur a distance of three centuries. In any case, I believe that a careful study of these historical efforts to revitalise legal and social principles such as that of practical reason, may be very useful to understand the context where the legal philosophy of Francisco Giner was forged, as well as its amplification and extension during the Spanish Silver Age. At the same time, I believe that studying this question has the relevant interest of involving a possible reading of Iusnaturalist Hispanic Classics from and for contemporary philosophical and legal culture, so I will also dedicate some lines to this subject.

Keywords: Francisco Giner de los Ríos; practical reason; Iusnaturalism; law.

Cuando se trata de analizar las múltiples influencias que ha recibido la obra jurídica y sociológica de Francisco Giner de los Ríos, es preciso reparar en ese proceso de recuperación krausista de los temas y la metodología jurídica de los clásicos hispanos de la Escuela del Derecho Natural. Para tratar de esta etapa de recuperación de las tesis iusnaturalistas que se despliega durante el siglo XIX y primeras décadas del XX, subrayaremos las concomitancias existentes entre los krausistas españoles y los clásicos españoles, para llegar hasta lo que consideramos un eslabón imprescindible en esta fase de recuperación de la doctrina del Derecho Natural: la lectura que hace el iusnaturalismo krausista de los clásicos hispanos.

Antes de iniciar este recorrido, consideramos oportuno señalar brevemente lo que nos motivó a emprender esta investigación sobre los precedentes de la filosofía social y jurídica de Giner en la Escuela de Derecho Natural española. El principal estímulo fue, sobre todo, el hallazgo de las patentes y enriquecedoras relaciones que pueden establecerse entre sus doctrinas, aunque quizá, el leitmotiv determinante para abordar este estudio fue la lectura de un artículo de Adolfo Posada, "El Cuerpo místico" del P. Suárez y el "Organismo social” del Maestro Giner», cuyo título es ya indicativo de ese intento de establecer de modo expreso la estrecha relación existente entre ambas corrientes de pensamiento:

Pienso que un estudio imparcial y sereno de la obra de no pocos de los «grandes españoles» de los siglos XVI y XVII — teólogos y filósofos del derecho, metafísicos y místicos- descubriría relaciones profundamente sugestivas entre sus actitudes espirituales, sus concepciones generales del mundo ético y jurídico y las de los llamados, entre nosotros, «krausistas», que no obstante sus atavíos europeos y a pesar de su formación ideológica bajo el influjo de las corrientes centrales de la filosofía alemana —Kant, 
Fichte, Schelling, Hegel, pero, sobre todo, Krause- tenían la raíz más honda de su alma en lo más íntimo del pensamiento místico y metafísico español. Algo de esto apuntaba D. Juan Valera en estas líneas de un pueblo a una de las ediciones de Pepita Jiménez (escrito en 1886, en Nueva York, 5. a edición de La Lectura, de 1927). «Entonces, decía Valera, me empeñé en demostrar que si Sanz del Río y los de su escuela eran panteístas, nuestros místicos de los siglos XVI y XVII lo eran también; y que si los unos tenían por predecesores a Fichte, Schelling, Hegel y Krause, Santa Teresa, San Juan de la Cruz y el iluminado y extático Padre Miguel de la Fuente, por ejemplo, seguían a Tauler y a otros alemanes, sin que yo negase a ninguno la originalidad española, sino reconociendo en esta encadenada transmisión de doctrina el progresivo enlace de la civilización europea». No lo olvidemos: «los de la escuela» de Sanz del Río, lo recuerda Valera, eran Salmerón, Giner, Azcárate, Federico de Castro y González Serrano (Posada, 1928: 118).

Bien claro parece de este texto de Posada, extractado del Boletín de la Institución Libre de Enseñanza, que el krausismo español no es hijo de la filosofía idealista alemana con exclusividad, y conviene reparar, pues, en que, junto a esos atavíos europeos, le acompañaron otros adornos y prendas que provendrían de la propia historia del pensamiento español. Por esta razón, trataremos de dar cuenta de este fenómeno de recuperación del legado de nuestros clásicos, que fue llevado a cabo, paradójicamente, no por quienes se presentaban como tradicionalistas, sino desde las premisas reformadoras y liberales krausistas que auspiciaron una lectura renovadora, en clave liberal y democrática, de sus doctrinas.

Con respecto a este tema, dice Adolfo Posada que este interés suyo por recuperar para su época la tradición de pensamiento de la Escuela de Derecho Natural española se despertó «al leer, de nuevo, en el gran infolio del P. Francisco Suárez S. J., en el tratado De Legibus ac Deo Legislatore, edición de 1613, puesto ahora en castellano por Torrubiano y Ripio, 1918, y al comparar o relacionar algunos de los razonamientos y concepciones de aquel insigne pensador español, teólogo y filósofo de primera magnitud, uno de los magni hispani que estudia Kohler, con ciertas ideas capitales del maestro Francisco Giner, expuestas y explicadas estas en algunos de sus libros, verbigracia, en sus estudios de Filosofía y Sociología y en varios de sus trabajos sobre La persona social» (Posada, 1928: 118). Corresponde, pues, a Adolfo Posada el incuestionable mérito de haber impulsado este proceso reivindicativo de los iusnaturalistas clásicos hispanos y su empeño por conjugarlo con el pensamiento ilustrado de la tradición krausista, en la común convicción que ambos tenían por revalorizar el papel social y 
democrático de las instituciones políticas tradicionales hispanas. Ello se pone particularmente de manifiesto en su afán por hallar afinidades entre el pensamiento del filósofo y teólogo jesuita Francisco Suárez con el pensamiento de su maestro, Francisco Giner, quienes, en efecto, presentaban profundas afinidades en materia de sociología y de filosofía política:

Se trata, no más, de notar cierta relación analógica entre el punto de vista del teólogo y filósofo de los siglos XVI y XVII (1548 a 1617) y su manera amplia de ver y definir, de concebir la «sociedad humana» en el «sistema» del mundo, de la realidad y de la vida: obra divina como un orden substantivo, o mejor, como un «Cuerpo», y el punto de vista de la concepción «orgánica» de la realidad, y en ella y como ella, de las «sociedades», sostenido por el maestro y filósofo del siglo XIX (y principios del xx, 1829-1915). [...] Hállanse ambos filósofos [Suárez y Giner] - magni hispani-, cada cual a su modo y en su momento, dentro de una de las corrientes más constantes y constructivas de la historia del pensamiento, como ahora diríamos, «sociológico»y «político» (Posada, 1928: 118-119).

En ese contexto se sitúan, pues, las obras de Francisco Giner, Adolfo Posada y Joaquín Costa, junto con otros de los más representativos exponentes del krausismo español y del espíritu regeneracionista del 98, que mostraron tener una notable erudición sobre el pensamiento jurídico y político hispano del Siglo de Oro y que hicieron sus aportaciones a este sector de la historiografía filosófico-jurídica de la Escuela de Salamanca. Se produce así lo que podríamos considerar un revival del iusnaturalismo en este periodo de la Edad de Plata española, en el que los regeneracionistas vuelven su mirada hacia los escritores del Siglo de Oro para buscar en ellos, como exponentes de los ideales de la España anterior a un largo periodo de decadencia, estímulos y revulsivos para reformar la vida cultural y política en España.

Ese propósito determina que su revisión de los clásicos suponga una lectura «interesada» —en el mejor de los sentidos del término- y que, las más de las veces, se subordine su gusto por la erudición filológica y metafísica a la intención pragmática que pretenden derivar de ese pensamiento hacia los problemas acuciantes del contexto ideológico del regeneracionismo de la España de finales del siglo XIX y principios del XX; por ejemplo, en su reivindicación de las libertades de los ciudadanos y de las personas sociales, de unos principios universales para el Derecho Internacional, la orientación de toda política al bien común, así como el derecho y el deber del pueblo a resistir la tiranía mediante la desobediencia a las 
leyes injustas, etc., ideas todas ellas presentes en el iusnaturalismo de la Escuela de Salamanca que vuelven a adquirir vitalidad y a fortalecerse en la doctrina krausista, y cuyas consecuencias se van a proyectar en todos los aspectos de la vida cultural y política española.

Dados, pues, estos antecedentes, encontramos en el citado artículo de Posada un testimonio de estas relaciones entre las concepciones generales de la Filosofía del Derecho y Sociología de Francisco Giner de los Ríos (1839-1915), con las ideas sobre el corpus mysticum de Suárez (15481617) expresadas en el De Legibus, en las que el krausismo encontraría, de modo indirecto, también su raíz histórica y doctrinal. La recuperación de esta idea del corpus mysticum a la que Posada dedica su estudio, a la manera en que lo expuso Francisco Suárez entre los escolásticos, vino principalmente de la mano de la noción de organicismo social y la caracterización de la sociedad hecha por la filosofía jurídica krausista y, a su través, por la obra de Rousseau: «A su tiempo, Rousseau, en el siglo XVIII, hablará del "yo común" de la sociedad que surge del pacto, y el "cuerpo místico" de Suárez resurgirá en las concepciones modernas del organismo social, como veremos en Giner» (Posada, 1928: 119).

El interés de Posada por hallar analogías entre las doctrinas de los magni hispani de la Escuela de Salamanca y las concepciones sociológicas y jurídicas de la moderna teoría gineriana del organismo social — por oposición a las teorías del individualismo atomista - representa un punto de inflexión muy interesante para la comprensión de la relación que Giner establece entre sociedad y Estado, entre la cuestión social y la cuestión política.

Vista con una lente del siglo XXI, la trascendencia de esta idea de la razón práctica, y la consiguiente distinción entre Estado y sociedad, aparecen como algo decisivo, y toda la doctrina adquiere un matiz de actualidad. Aunque ni Suárez ni Giner se plantearon el problema que ha agitado a la conciencia científica de hoy, es, sin embargo, un hecho que trazaron con toda claridad esta diferencia entre el Estado oficial y el Estado no oficial, y que la misma puede poseer, en sí, un gran alcance para la teoría social contemporánea. Por esta razón consideramos muy valioso el empeño de Posada de buscar «coincidencias de concepto o de orientación, o de puntos de vista, entre los grandes pensadores que han intentado dar solución o explicación a algunos de los eternos y constantes problemas, dignos siempre de la reflexión humana» (1928: 117), y, por tanto, creemos que merece la pena seguir indagando en las conexiones que hay en la doctrina jurídica y social de ambos pensadores. 
Pensamos que este análisis de la naturaleza de la sociedad, tan esencial en Derecho como en Sociología, y del carácter real y sustancial de las personas sociales ginerianas - entendidas a la manera del corpus mysticum suareciano como corporaciones donde hay un consorcio de voluntades-, puede suscitar nuevas respuestas a la luz de los nuevos conocimientos de la sociología y la cultura jurídica presente, así como ofrecer algunas claves para la comprensión del legado doctrinal de los pensadores clásicos. Así lo ha hecho ver Rainer Specht en su artículo «Derecho natural español. Clasicismo y modernidad», donde afirma que la herencia intelectual de los principales tratadistas del Derecho Natural constituye

un punto culminante de la Filosofía práctica formulada en términos de moral science, y se cuenta entre las construcciones más impresionantes que ha forjado nuestra civilización: una Filosofía práctica que abarca toda la realidad. Que haya sido olvidado por nuestra conciencia cultural, a veces poco cuidadosa en la conservación de los fenómenos, es una de las razones que impiden hoy a la opinión pública comprender a Europa como unidad cultural (Specht, 1990: 343-354).

Nos referiremos, pues, a esta valiosa y persistente tradición de pensamiento de los magni hispani, que tiene en Francisco Suárez a uno de sus más excelsos representantes, para tratar de establecer cuáles fueron los rasgos distintivos comunes de esos clásicos iusnaturalistas, ver si se dio entre ellos algún tipo de coincidencia de inquietudes o incluso de comunidad de método o enfoque, y, finalmente, para indagar en qué consistió su legado doctrinal y qué aspectos tuvieron una mayor amplificación a finales del siglo XIX y principios del Xx, tal y como fueron recibidos por el krausismo decimonónico español. Desde luego, dar cuenta pormenorizada de las diferentes actitudes hermenéuticas avanzadas de esos pensadores iusnaturalistas resultaría una tarea excesiva, cuando no inabarcable, por lo que nos limitaremos a bosquejar un itinerario orientador de los principales aspectos y posiciones más representativos de esta Escuela de Derecho Natural a fin de analizar sus posiciones doctrinales en temas que fueron apreciados y desarrollados por los krausistas españoles y que todavía siguen abiertos en los debates contemporáneos, como es el problema de la definición y función de los conceptos de razón práctica y epiqueya. Tratemos, pues, de resumir los aspectos básicos más modernos del pensamiento clásico iusnaturalista español, circunscribiendo nuestro análisis de la Escuela de Derecho Natural a aquellos rasgos comunes de su concepción del Derecho que han sido elaborados, secundados e interpretados por la literatura crítica krausista. 
Una de las tesis principales de la Escuela de Derecho Natural española es la fundamentación racional del orden jurídico, lo cual supone, como punto de partida, un rechazo de las tesis no-cognitivistas - como el escepticismo, relativismo e irracionalismo- en tanto en cuanto el iusnaturalismo defiende la competencia de la razón práctica para fundamentar las normas y juicios morales. La incompatibilidad con estas corrientes nocognitivistas es clara, pues al afirmar los escépticos y relativistas la indeterminación radical del Derecho, renuncian así a una de las notas más esenciales para el iusnaturalismo español, al elemento deliberativo y racional que es capaz de generar expectativas de reforma en la sociedad, dado que sus tesis escépticas impiden todo intento de justificación racional. Buena muestra de ello es el escepticismo con el que muchos autores críticos se refieren a los derechos fundamentales, lo cual evidencia también un cierto alejamiento de lo que hoy constituye una seña de identidad de las tesis progresistas y de las posiciones doctrinales que, tanto en la época de Giner como en nuestros tiempos, sostienen con mayor énfasis la fe en el Derecho y la lucha contra la injusticia que este promueve. Así lo hizo notar uno de los más importantes discípulos de Giner, Adolfo Posada, en la traducción directa del alemán de La lucha por el Derecho de Rudolf von Ihering:

aquí se habla de la lucha del Derecho contra la injusticia. Si en esta hipótesis el Derecho no lucha, es decir, no hace una heroica resistencia contra aquella, se negará a sí mismo. Esta lucha durará tanto como el mundo, porque el Derecho habrá de prevenirse siempre contra los ataques de la injusticia. La lucha no es, pues, un elemento extraño al Derecho; antes bien, es una parte integrante de su naturaleza y una condición de su idea (Ihering, 1974: 7-8).

Se trata, en efecto, de emprender una lucha por el Derecho, por decirlo con una expresión que tanto gustaba emplear a krausistas como Posada o Giner. Esta fórmula no solo es el título de un libro de Ihering que Posada tradujo al español, sino que tuvo una mayor significación, sirviendo casi podríamos decir de lema frente a la pobreza de ideales del positivismo vigente abocado al inmovilismo social, y sirviendo al mismo tiempo de acicate para los ánimos decaídos, pues hay momentos, como dice Giner siguiendo en esto a Ihering, en que «el teórico se anticipa al sentido de su época» (1899: 30).

El prólogo de Clarín a esta obra de Ihering resume muy bien las enseñanzas que había recibido de Giner en sus clases de doctorado, e interesa traerlo a colación porque está impregnado de las aspiraciones o ideales 
krausistas en la lucha contra la injusticia que se libraba en el contexto decimonónico español:

[son] sofismas que se conocen con nombres más o menos huecos, más o menos bárbaros; sofismas que toman su apariencia de argumentos de donde pueden, ora de las ciencias naturales, y hablan entonces de evolución; ora de mal interpretados positivismos y experimentalismos, y entonces hablan de lo posible, de lo oportuno, de lo práctico, de lo histórico. Y existe una íntima relación entre una y otra enfermedad de nuestro espíritu liberal, y por esto, si del mal primero, del formalismo, se puede decir que ya casi todos hace tiempo están contagiados, no será extraño que la nueva laceria, el posibilismo que se llama, o quietismo que podría llamarse, lleguen a padecerla aquellos liberales que hoy no la conocen, por fortuna. Es evidente que un mal se engendra de otro: poco importa que los apóstoles de la pasividad política, del indiferentismo disfrazado de hipócritas apariencias de misticismo político se digan inspirados por la ciencia, por la moderna idea, por los adelantos de los estudios históricos y naturales; de todo esto toman el color, pero en calidad de enfermedad el quietismo (que también podría decirse jobismo, ya que tanto agradan los nombres nuevos) se deriva necesariamente de la influencia formalista que por vicio secular padece el concepto del derecho más vulgarizado (Clarín, 1921: XII-XIII)

Bien se aprecia en estos fragmentos cómo los iusnaturalistas krausistas emprenden sus críticas contra el escepticismo y las tesis inmovilistas a que abocaba el positivismo normativista más formalista, pues al centrarse este en discursos descriptivos o meramente explicativos, cuando no puramente críticos de cualquier intento de legitimación del Derecho, no se dejaba lugar para un discurso justificativo, imposibilitando así algo que es crucial para el krausismo: que se pueda dar cuenta del discurso interno del Derecho, de su relación con la moral, de su legitimación. En verdad, hay en el fondo de las tesis irracionalistas y del emotivismo ético algo contrario a la filosofía jurídica krausista: la consideración de la justicia como un ideal irracional y, en consecuencia, la negación total de la posibilidad misma de la razón práctica. Esta visión posmodernista del Derecho, naturalmente más presente hoy en día que en la época de Giner, y cuya trayectoria se deja sentir también en ese periodo de finales del XIX y principios del Xx en que Giner escribe, puede mostrarse en la obra de algunos autores contemporáneos del realismo jurídico (Frank, Wendell \& Nickerson, 2008: 117-133) y en los enfoques críticos del derecho (Boaventura o Kennedy), quienes comparten también este carácter antirracionalista que les lleva a defender versiones fuertes de escepticismo epistemológico y 
de relativismo cultural y que hacen, por lo tanto, imposible un discurso propiamente justificativo.

Pero si se aceptaran las tesis escépticas y puramente descriptivas de su teoría crítica, ¿para qué preguntarse entonces por la posible mejora del ordenamiento jurídico o por la relación entre Derecho y Moral, que, como sabemos, es uno de los grandes temas de la Filosofía del Derecho krausista? Obviamente, para los escépticos, formular esta pregunta no tiene sentido y no aporta nada a la ciencia jurídica. Y es precisamente aquí donde radica una de las críticas más certeras que hacía Clarín (1921: XIIXIII) a estas tesis escépticas por incurrir en una especie de contradicción pragmática, pues se trata de una concepción que, al mismo tiempo que trata de promover cierto compromiso con la práctica, renuncia a establecer criterios que puedan servir de guía a esa práctica, abocándonos así a esa enfermedad del quietismo estéril. Por lo tanto, el escepticismo no solo viene a refutarse a sí mismo por ser un principio impráctico, sino que lo hace de manera peligrosa al minar por su base cualquier intento de discurso racional y, en tal sentido, nos parece que la doctrina krausista aporta una perspectiva más ajustada y cabal del Derecho.

Ciertamente no todas las críticas dirigidas al escepticismo por los defensores de una racionalidad práctica han sido tan certeras; positivistas como Norberto Bobbio o Hans Kelsen también han criticado ese supuesto idealismo y falta de realidad que habría en el iusnaturalismo, no para minar de modo tajante cualquier posibilidad de fundamentación del Derecho, sino para salvar precisamente el pluralismo de los sistemas de legitimidad y defender que las normas de justicia no constituyen sino valores relativos:

La negativa a admitir, desde el punto de vista del conocimiento científico, la existencia de un ser trascendente situado por encima de toda posible experiencia humana, es decir, la oposición a la existencia de lo absoluto en general y de valores absolutos en particular, conduce, desde el punto de vista de una teoría científica del derecho, a la afirmación de que la validez del derecho positivo no puede depender de su relación con la justicia. Semejante dependencia no podría, en efecto, existir más que si la justicia fuese un valor absoluto, es decir, si se supone la validez de una norma de justicia que excluye la validez de cualquier otra norma que no esté conforme con aquella. Si se admite que puede existir una pluralidad de normas de justicia diferentes y eventualmente contradictorias, en el sentido de que cabe presuponer como válida tanto una como otra de dichas normas, y si, por consiguiente, el valor de justicia se presenta como relativo, resultará que todo ordenamiento jurídico positivo entrará fatalmente en contradicción con una u otra de estas normas de 
justicia y no habrá, por tanto, en virtud de esa contradicción con alguna de las normas de justicia, ordenamiento jurídico positivo que no deba ser considerado inválido. Pero, al mismo tiempo, y por otra parte, todo ordenamiento jurídico positivo puede ser conforme a una cualquiera de las numerosas normas de justicia que solamente constituyen valores relativos sin que esta conformidad sea considerada como fundamento de su validez (Kelsen, 1966: 100-101).

Los autores positivistas contemporáneos consideran que una norma puede ser válida sin necesidad de que sea justa, pues parten de la total independencia del Derecho en su relación con la justicia. En tal sentido, denuncian el idealismo caballeresco y escapista del iusnaturalismo, al cual, un realista como Holmes, refiriéndose a este mismo empeño iusnaturalista de preservar una idea de justicia universal, lo había comparado en una ocasión con los caballeros a los que no basta con que se reconozca que su dama es hermosa, sino tiene que ser la más bella que haya existido y pueda llegar a existir (Holmes, 1920: 310; citado en Atienza, 2005: 25-34). Este argumento, en tono un tanto sarcástico, vendría a recusar esa vocación de universalización e inmutabilidad que hay siempre en las tesis iusnaturalistas.

A este respecto, y ante una eventual crítica positivista a la filosofía krausista, conviene advertir que no hay en el krausismo una complacencia ni un asentimiento acrítico que imponga una ley natural de modo abstracto y uniforme. Como puede deducirse de las obras de Giner y Posada, los krausistas españoles son conscientes de que todas las creencias y valores son relativos a otras creencias y valores, así como a la comunidad y las prácticas sociales determinadas en que se aplican. Ahora bien, la aceptación de esta tesis no nos conduce necesariamente a la tesis relativista que sostiene que la crítica es imposible entre distintas culturas:

No todas las prácticas sociales están, entonces, blindadas contra todo tipo de crítica por razones. Nadie afirma que sea imposible criticar todo tipo de creencias (y esto implica creer que al menos algunas prácticas pueden ser criticadas). Afirmar tal cosa significaría negar que los individuos pueden cambiar de creencias en virtud de las razones de otros y de las propias (Valdecantos, 1999: 57).

Conviene, pues, distinguir bien esta versión del escepticismo contemporáneo - contra la que se pronuncian los krausistas y los iusnaturalistas clásicos-, cuya obsesión es probar que todas las creencias son incapaces de resistir a la crítica, por oposición a lo que constituía el fin del escepticismo clásico, a saber: buscar el modo en que cualquier creencia puede ser puesta en cuestión, lo cual implica un clima mental de respeto y aprecio 
por lo diferente, que está en la línea de esta tradición clásica española, en la que hay una clara apuesta por el diálogo y la racionalidad de la acción. No otra cosa propone el krausismo español que, por encima de sus posicionamientos, supone la elaboración y reelaboración de una doctrina de manera libre, autónoma y sin prejuicios, para la cual, dice Giner, «todo acto de justicia contribuye a afirmar esta virtud en la conducta, no solo por lo que el hábito consolida la recta disposición del sujeto, sino por el influjo de su ejemplo sobre los demás: aquí es donde se halla la mejor garantía» (1926: 136).

Este principio racional del orden jurídico es el que sería posteriormente reelaborado por el iusnaturalismo krausista del siglo XIX y de principios del siglo Xx, particularmente en su concepción de la racionalidad como libertad, que exige que la norma moral que la acción cumple satisfaga el principio de universalización, es decir, que pueda encontrar un reconocimiento general en su ámbito de aplicación. Por esta razón, la doctrina de los iusnaturalistas clásicos hispanos sigue siendo familiar a la teoría jurídica y política del presente, que es una teoría de la acción racional.

No obstante, conceptos tales como «razón» y «res publica», o el más ambiguo y polisémico de todos de «naturaleza», aunque sean utilizados sin hacer mayores especificaciones, han variado notablemente y adoptado diferentes ropajes en los últimos cuatrocientos años. En general, puede afirmarse que la Filosofía del Derecho de hoy en día pone un mayor énfasis en que la razón debe servirse de orientaciones históricas y sociales; de ahí que Giner haga hincapié en que lo que es recto no lo puede fijar una razón abstracta, sino una razón práctica que se mueve en contextos históricos determinados y que se dirige a fines concretos:

[Se trata de la] dilucidación en cada momento de lo que hay de eterno y permanente (principio de la filosofía), lo que hay de temporal y mudable (hechos de la historia) y la acomodación de los principios a los hechos (filosofía de la historia). [...] Manifiéstase el Derecho en una serie de estados particulares, necesariamente mudables y sucesivos, que son sus manifestaciones temporales, o los hechos jurídicos. La serie toda de dichos estados en que el Derecho, sin perder por eso nada de su inagotable fondo, se muestra, es lo que constituye la vida del Derecho: pues que en general es la vida aquella propiedad por la que un ser determina su esencia y cualidades en estados sucesivos (Giner, 1916: 58).

Esta concepción de la racionalidad práctica que retoman los krausistas tiene, pues, un claro precursor en el papel que los iusnaturalistas clásicos españoles concedieron a la fuerza de la razón en el Derecho. En virtud 
de este principio racional, los iusnaturalistas clásicos han sido considerados como el eslabón entre el Derecho Natural clásico y el moderno. Sin embargo, su concepto del Derecho, como toda doctrina de transición, presenta rasgos ambivalentes, pues siguen fieles a una fundamentación metafísica del orden jurídico y a unas «razones últimas» de tipo ontológico que conforman el substrato axiológico material de sus construcciones. Por esta razón, de los clásicos españoles, en su papel de eslabones de conexión entre el pensamiento medieval y el moderno, se ha dicho que les incumbe una tarea decisiva en el proceso de secularización del iusnaturalismo teológico medieval que condujo a la Escuela del Derecho Natural racionalista. A este respecto conviene recordar, por ejemplo, cómo Francisco Suárez coadyuvó a la formación del imperio de la ley al proclamar que, tras las disposiciones específicas de la ley, existían unas normas racionales de validez general, que él llamó ley natural, a la que todos estamos sometidos y que a nadie, ni siquiera al papa, le estaba dado modificar. De igual modo, los argumentos de la Escuela de Derecho Natural española llevaron hasta sus últimas consecuencias el postulado tomista de la autonomía del orden humano regido por la racionalidad natural, respecto al orden trascendente de la fe y de la gracia, lo cual implicaba un abandono del objetivismo ontológico en función de un subjetivismo tendente a potenciar la dimensión del Derecho como conjunto de facultades de la persona; una doctrina que preanunciaba la modernidad y que conocería un desarrollo mayor en el concepto de Derecho inmanente gineriano: «En la fidelidad [de Giner] al principio de la inmanencia en el Derecho, se encuentra, a nuestro juicio, la base de la que con razón llama el señor Dorado Montero (El Derecho y sus sacerdotes, pág. 580, nota) escuela española de filosofía del Derecho» (Ríos Urruti, 1916: 110-111).

Se opera, pues, una transición del a priori trascendente que imponía una realidad objetiva con la indiferencia soberana de la omnipotencia divina, a un a priori práctico de la voluntad, inmanente, basado en la necesidad natural del hombre considerado en su estado originario.

En cualquier caso, y habida cuenta de sus limitaciones, es en estas concepciones racionalistas donde reside la gran aportación del Derecho Natural a la conformación del humanismo, al desarrollo de las libertades y a la legitimación democrática del poder. Por esta razón, consideramos que en la actual coyuntura filosófico-jurídica, abierta al reconocimiento de la competencia práctica de la razón para establecer pautas éticas 
fundamentadoras de una convivencia social justa, la doctrina de los clásicos iusnaturalistas hispanos sigue representando un provechoso estímulo.

Otro aspecto recurrente en las aportaciones bibliográficas actuales al estudio de los iusnaturalistas clásicos hispanos es el referido a su papel en la génesis y evolución de los derechos humanos y en el reconocimiento de su decisiva participación en la génesis del Derecho Internacional. En esta materia, destacan sobre todo las tesis humanitarias de Bartolomé de las Casas en el Debate de Valladolid (1550) y del considerado hoy padre del Derecho Internacional, Francisco de Vitoria, en respuesta a los problemas éticos planteados por el descubrimiento de América. Vemos, pues, que a estos autores clásicos hispanos les incumbió un decisivo papel en la constitución del acervo teórico iusnaturalista que conformaría luego el Derecho Internacional. Una vez más, su punto de vista sobre la ley natural se vio puesto a prueba y, nuevamente, su concepto de Derecho no quedó reducido a un código rígido e inmutable, sino que supieron adaptar a los nuevos tiempos y a las exigencias concretas de su época los preceptos del Derecho Natural, dando solución a numerosos conflictos éticos y jurídicos que les fueron planteados por vez primera.

Asimismo, debe recordarse que en este contexto histórico e ideológico de los siglos XVI-XVII se estaban fraguando las bases de la Teoría del Derecho Natural moderno, las cuales estaban ligadas a una serie de rasgos característicos de su marco político, como fueron la aparición del Estado moderno, las teorías absolutistas y la consolidación de la potente locomotora de la «razón de Estado» que arrasaría en Europa en el contexto de las doctrinas monárquicas (Sabine, 1965: 291 ss.).

Detengámonos un poco en este aspecto, pues iusnaturalistas clásicos como Francisco Suárez defendieron un concepto de soberanía opuesto al de estas doctrinas de las monarquías absolutas de su tiempo y a la puesta en marcha del concepto de razón de Estado de Maquiavelo. Un enfoque suareciano del Derecho que, al mismo tiempo que se enfrenta a estas doctrinas de la «razón de Estado», guarda una estrecha relación con la definición de soberanía que ofrece Francisco Giner nada desdeñable.

Como es bien sabido, la reflexión de Maquiavelo sobre la razón de Estado parte de desprender o separar la filosofía política de toda teología y ética, para así ganar la autonomía de lo estrictamente político. Se trata de una secularización de la soberanía consistente en hacer valer la independencia total del Estado. De acuerdo con Maquiavelo, el Estado puede y debe ser amoral, inmoral o moral según convenga, es decir, según la razón misma de su conservación y del incremento de fuerza, pues de lo 
que se trata es del «Estado», de su razón, de incrementar su poder. De aquí proviene el manido lema de que el fin justifica los medios, según el cual, el fin de incrementar su poder justificaría todos los medios empleados, desde mentir hasta no respetar los convenios ni las promesas, así como el uso retórico del Derecho por el Príncipe para mantener ciertas apariencias engañosas en su provecho. Por lo tanto, no se toma en consideración la moralidad de los medios empleados, ni se trata de descubrir eso «justo» que hay en el Derecho; por este motivo, en lugar de la dialéctica como método de razonamiento encaminado a la verdad, cuyo conocimiento es posible y necesario para los iusnaturalistas, se ensalza el valor de la retórica en ese nivel básico instrumental para servir mejor a la razón de Estado.

Todo esto se traduce en materia de política internacional, podríamos decir con Hobbes, en el reino del estado natural en que cada Estado queda abandonado a sus propias fuerzas, pues de lo que se trata es que cada uno busque su propia auto-afirmación, su propio provecho. «Mi patria ante todo, con razón o sin ella», o, en otras palabras, «legalidad, con moralidad o sin ella», una expresión reivindicada por algunos juristas positivistas contemporáneos en la que reverberan ciertos ecos de la tesis de Maquiavelo, donde lo que pasa a primer plano no es cuestionarse por la justicia de determinada resolución, sino preguntarse qué bien particular nos ha de traer proseguir con determinada política para mantener el Estado, es decir, todo aquello que hace que persista en su ser, que aumente su fuerza, sin importar los medios que puedan emplearse para alcanzar dichos fines. En estas sentencias queda claramente expresada la razón de Estado, la consideración de los fines utilitarios que puedan ayudar al Estado, sin consideración alguna de una conciencia universal de justicia. Por esta razón, krausistas como Fernando de los Ríos no dudan en dirigir sus más encendidas críticas a las doctrinas que persiguen un estatalismo exacerbado:

El Estado, pues, no nace, para estos pensadores, porque haya de cumplir una misión esencial y positiva a lo humano, sino porque es preciso un orden inhibitorio que paralice las acciones dañosas que intentemos realizar, o las castigue una vez cumplidas. ¿Es otra la razón que determina en Kant el advenimiento del Derecho público? Se trata para él, simplemente, de asegurar lo mío y lo tuyo, que ya tenemos en el estado de naturaleza; de aquí que el Derecho público o civil, como le llama él con exactitud, a nuestro juicio, no tenga un contenido jurídico propio; su razón de ser es amparar, vigilar para que no se haga; es, pues, el Estado policía, como gráficamente ha sido designado, y al Derecho, que de él se ocupa, se le llama adjetivo. Su necesidad no se funda en lo que hace, sino en lo que evita hacer; no por la moralidad que tengamos, sino por aquella de que 
carecemos, surge el Estado; es un recuerdo perenne de nuestra imperfección (Ríos Urruti, 1916: 184-185).

De modo semejante a como los krausistas se opusieron a las tendencias formalistas y estatalistas del Derecho, la obra de Suárez y de los tratadistas iusnaturalistas de la Escuela de Salamanca en general, apunta también en una dirección completamente opuesta a esta de Maquiavelo y de Hobbes, trazando en este sentido lo que podría denominarse como una línea antimaquiavélica en la filosofía jurídica española que llega hasta los krausistas:

error de Maquiavelo y de los políticos: que ante el gobierno temporal no hay que preocuparse de lo espiritual. Acerca del problema propuesto pueden citarse dos opiniones. Una es que poder seglar y el derecho lo que buscan directa y primariamente es la estabilidad política y su conservación; que el tema y, por consiguiente, la materia de las leyes es lo que sirve para la estabilidad política y para su conservación y progreso; y que en orden a este fin se dan las leyes, ya se encuentre en ellas una verdadera honestidad, ya solamente una honestidad fingida y aparente, incluso disimulando lo que es injusto si resulta útil para el estado temporal. Es la doctrina que los políticos actuales, y el que más ha tratado de persuadirla a los príncipes seglares ha sido Maquiavelo, fundándose únicamente en que de otra manera no puede conservarse el estado temporal, de donde procede su perverso juicio de que no puede ser rey verdadero y inestable quien se atiene a las leyes de la virtud y se somete en todo a ellas (Suárez, 1967: 240-246).

A esta línea de pensamiento antimaquiavélica en España coadyuvó la noción del «bien común», otro de los conceptos clave de la Escuela de Salamanca, gracias al cual se logró imprimir una orientación y carácter a la doctrina iusnaturalista que ha sido muy fecunda para posteriores versiones iusnaturalistas como la krausista. De acuerdo con este concepto central del bien común, se determinaba que el fin del buen Príncipe no es otro que el bien de la comunidad. Por ello, en aras de conseguir y preservar el citado bien común, ciertos principios de justicia debían condicionar el ejercicio del poder político, lo que venía a justificar y legitimar el reconocimiento del ius belli (más usualmente conocido por la expresión escolástica de la guerra justa, bellum justum). Aquí quedaba fundado el derecho de resistencia frente a un gobierno tiránico, esto es, el derecho a la resistencia activa cuando el rey obre contra las normas del Derecho Natural o abandone el fomento del bien público. Sobre esta cuestión, sentencia Francisco Suárez que cuando el monarca traspasa el límite de la esfera de sus atribuciones lícitas, entonces debe renacer la soberanía popular originaria. 
Asimismo, de la idea del bien común se deriva también otro principio determinante muy ligado a lo anterior: la idea de que la justicia está por encima de las conveniencias políticas, de las razones patrióticas o de Estado, puesto que es algo que va más allá de cualquier pueblo. Se trata, pues, de sentar unos principios de justicia que interesen a toda la humanidad, pues no son los intereses particulares de uno u otro Estado lo que está en juego, sino la idea misma de justicia. De acuerdo con la doctrina iusnaturalista, la idea del bien común debe prevalecer sobre los intereses particulares del Príncipe y sobre esa razón del Estado maquiavélica a la que nos hemos referido; gracias a este principio moral entre los pueblos, fue posible hablar de la necesidad de «causa justa» para la declaración de la guerra y para sentar las bases del Derecho Internacional que tan importante fue luego para asentar el Ideal de la Humanidad krausista: «el género humano, aunque de hecho está dividido en pueblos y reinos, mantiene, sin embargo, en todo momento una cierta unidad, no ya solo la específica, sino cuasipolítica y moral como lo indica el precepto natural de la solidaridad y ayuda que se extiende a todos, incluso extranjeros y de cualquier nación» (Suárez, 1967: 135).

De lo dicho puede colegirse cómo la noción del bien común (Gemeinwohl) consiguió, por un lado, establecer los límites del poder estatal, fundamentar los derechos humanos, y por otro lado, sentar las bases de un modelo de referencia para el Derecho Internacional humanitario, que sirviera para controlar el empleo de ese instrumento terrible, y al mismo tiempo necesario, que es el Derecho.

Pero, indiscutiblemente, uno de los aspectos más estudiados en la Escuela de Salamanca, y que más tarde pasaría a ocupar un lugar central de la filosofía jurídica y política gineriana, es el que contribuyó a consagrar las libertades fundamentales del individuo, aunque con el caveat -que conviene considerar y que se pone de manifiesto en el completo e interesantísimo libro del profesor Antonio-Enrique Pérez Luño sobre este periodo histórico, cuya exposición aquí seguimos de cerca- de que «fueron ideas elaboradas para un contexto presidido por una ética social sin asomo de derecho individual; siendo el nuestro tiempo de derecho individual sin ética social» (1992: 116).

Así - tal como se ha puesto de manifiesto en algunos manuales de Derecho Constitucional-, conviene «advertir, con Álvarez Conde, que "en la defensa de los derechos del hombre es donde mejor encontramos la modernidad de esta Escuela, y su aportación a la democracia junto con el principio de soberanía popular matizado, que encontramos en Suárez". 
En definitiva, es en la Escolástica española donde comienza a andar el camino que con el tiempo culminará en el Estado Constitucional» (Navas \& Navas, 2005: 54).

Al manifestar de modo terminante e inequívoco que la salvación moral del sujeto humano era algo regulado por la ley moral natural y, por tanto, que era una cuestión que debía ser decidida por el individuo — sin que en esta materia el derecho positivo debiera imponerle una regulación imperativa-, se estaba asentando la base fundamental de los derechos de libertad, de la cual luego se impregnaría el krausismo, y muy especialmente, «la concepción sociológica ética y jurídica de Giner, alcanza[da en] el principio de lo "inmanente" en el Derecho» (Posada, 1928: 119-120), al que Giner dota incluso de entidad jurídica como Estado individual.

A este respecto, tal teoría iusnaturalista plantea un problema ético fundamental, que no solo atañe a los juristas, sino a cualquier persona preocupada por los límites del Estado y de sus servidores, y que establece que solo se debe obedecer a la autoridad en cuanto se mantenga dentro de sus atribuciones legales y no ataque u olvide los imperativos del Derecho Natural, lo cual implica la remisión a criterios morales para legitimar el orden jurídico. En este plano de la fundamentación de los derechos humanos, frente a las posturas individualistas y positivistas, tanto los clásicos hispanos como los krausistas españoles decimonónicos defienden y reivindican el fuero de una posición intermedia (social-individualistische). Dicha posición sería la única capaz de conjugar los valores individuales de la persona en función de su racionalidad, con la sociabilidad natural humana heredada de la tradición aristotélico-tomista que define al hombre como zoon politikon y que, por tanto, concibe la plena realización del ser humano en su incorporación a la sociedad y al Estado. De hecho, entre los aspectos que caracterizaron el pensamiento político krausista destaca precisamente su confianza en la sociedad como un elemento nuclear e intermedio entre el individuo y el Estado, y cuya autonomía encuentra en el concepto de selfgovernment su mejor expresión ${ }^{2}$.

Confiamos en que este breve esbozo de las principales tesis de la Escuela de Salamanca sobre el Derecho, la política y las libertades, sirva

2. Sobre la complexión y alcance del Estado social y el Estado individual en la obra de Francisco Giner, véanse los artículos «Dos en uno. El concepto de Estado individual krausista y su relevancia biopolítica» (2009) y «La micrópolis del yo. Representación, soberanía e individuo en los escritos de Francisco Giner de los Ríos» (2007: 199234) de José Manuel Vázquez-Romero. Sobre el autor que popularizó el concepto del selfgovernment, Gumersindo de Azcarate, véase Capellán (2005). 
para asentar algunos de los principios fundamentales de la Filosofía del Derecho gineriano y ayude a comprender su posición doctrinal y sus esfuerzos por vincular el Derecho a la Moral como un medio objetivo y necesario para garantizar su realización.

A modo de síntesis, puede concluirse que la vindicación de la superlativa necesidad de armar al individuo de una malla férrea de garantías por medio del concepto de racionalidad práctica que garantice la limitación democrática del ejercicio del poder estatal y el arbitrio del poder público, y que ya estaba presente en estado embrionario en los autores de la Escuela de Derecho Natural española, es un pensamiento que ha tenido gran proyección e influencia en el iusnaturalismo hispano: primero en la Ilustración, lo cual puede verse en el gran protagonismo cultural que tuvieron los miembros de la Escuela de Derecho Natural y su implicación en episodios clave de la formación de la identidad moderna — ello ha sido analizado por diversas obras que estudian este nexo entre la Compañía de Jesús y la modernidad (Betrán, 2010)—; y posteriormente, a través del tamiz de la filosofía krausista, donde conoce un nuevo desarrollo, con una proyección en el pensamiento contemporáneo que alcanza hasta nuestros días, donde conserva su interés en el proceso de fundamentación de los valores de los Estados de Derecho y donde encuentra su mejor realización práctica en todos los regímenes constitucionales de los países efectivamente civilizados ${ }^{3}$.

\section{Bibliografía citada}

ATIENZA, M., «Argumentación jurídica y Estado constitucional», en María José Añón \& Pablo Miravet Bergón (eds.), Derecho, justicia y Estado, Valencia, Tirant lo Blanch, 2005, pp. 25-34.

BETRÁn, J. L., La Compañía de Jesús y su proyección mediática en el mundo hispánico durante la Edad Moderna, Madrid, Sílex Ediciones, 2010.

CAPellán de Miguel, G., Gumersindo de Azcarate: biografía intelectual, Valladolid, Junta de Castilla y León, 2005.

[CLARÍN] GarCíA-AlaS Y UReÑA, «Prólogo» a Rudolf Von Ihering, La lucha por el Derecho, trad. Adolfo Posada, Madrid, Nueva Edición, 1921.

Frank, J., O. Wendell Holmes \& K. NiCKerSOn LleWellyn, «Legal Realism and Skepticism», en J. Feinberg \& J. Coleman (eds.), Philosophy of Law, Belmont (USA), Thomson Higher Education, 2008, 8. ${ }^{a}$ ed., pp. 117-133.

3. Véase al respecto uno de los más recientes estudios colectivos dedicados al pensamiento gineriano (Vázquez-Romero, 2009a) donde se pone de manifiesto la actualidad de la obra de Francisco Giner. 
GINER DE LOS Ríos, F., «La Ciencia, como función social», BILE [Boletín de la Institución Libre de Enseñanza], 23, 1 (1899), pp. 26-32, 55-64.

- \& Alfredo CALDERón, Prolegómenos del Derecho [Obras completas, I], Madrid, Espasa-Calpe, 1916.

- \& Alfredo Calderón, Resumen de Filosofía del Derecho [Obras completas, XIV], Madrid, Espasa-Calpe, 1926.

IHERING, R. von, La lucha por el Derecho, trad. Adolfo González Posada, Buenos Aires, Editorial Heliasta, 1974.

KELSEN, H., «Justicia y Derecho natural», en AA. VV., Crítica del Derecho Natural, ed. y trad. Elías Díaz, Madrid, Taurus, 1966, pp. 29-163.

Navas Castillo, A. \& F. Navas Castillo, Derecho Constitucional: Estado Constitucional, Madrid, Librería-Editorial Dykinson, 2005.

PÉREZ LuÑo, A. E., La polémica sobre el nuevo mundo: los clásicos españoles de la Filosofía del Derecho, Madrid, Trotta, 1992.

PosadA, A., «El "Cuerpo místico" del P. Suárez y el "Organismo social" del Maestro Giner», BILE, 52, 1 (1928), pp. 117-121.

Ríos URruti, F. de los, La Filosofía del Derecho en Don Francisco Giner y su relación con el pensamiento contemporáneo, Madrid, Biblioteca Corona, 1916.

Sabine, G., Historia de la Teoría Política, trad. Vicente Herrero, México, FCE, $1965,3 .^{\mathrm{a}} \mathrm{ed}$.

SPECHT, R., «Derecho natural español. Clasicismo y modernidad», Anuario de Filosofía del Derecho, 7 (1990), pp. 336-390.

SuÁrez, F., Tractatus de Legibus ac Deo Legislatore. Tratado de las leyes y de Dios Legislador [reproducción anastática de la edición príncipe, Coimbra, 1612], edicion bilingüe, trad. J. R. Eguillor Muniozguren, intr. L. Vela Sánchez, Madrid, Instituto de Estudios Políticos, 1967.

ValdeCantos, A., Contra el relativismo, Madrid, Visor, 1999.

VÁzQUEZ-ROMERo, J. M., «La micrópolis del yo. Representación, soberanía e individuo en los escritos de Francisco Giner de los Ríos», Pensamiento. Revista de Investigación e Información Filosófica, 63, 236 (2007), pp. 199-234.

- (ed.), Francisco Giner de los Ríos: actualidad de un pensador krausista, Madrid, Marcial Pons, 2009a.

- «Dos en uno. El concepto de Estado individual krausista y su relevancia biopolítica», en J. M. Vázquez-Romero (ed.), Francisco Giner de los Ríos; actualidad de un pensador krausista, cit. supra (2009b), pp. 27-82.

Fecha de recepción: 13-6-2015

Fecha de aceptación: 8-10-2015 



\title{
PANENTEÍSMO Y MÍSTICA ACTIVA EN «A DON FRANCISCO GINER DE LOS RÍOS», DE ANTONIO MACHADO ${ }^{1}$
}

\author{
Ángel L. PRieto de Paula \\ Universidad de Alicante
}

\section{Resumen}

El poema necrológico que dedica Antonio Machado a Francisco Giner de los Ríos es un retrato moral del homenajeado, pero también una proyección de la personalidad del poeta, que presta su voz para que el muerto exponga a sus discípulos el núcleo de su doctrina. El tema de la composición constituye un modelo ético en el que se confunden dos propuestas morales hasta convertirse en una sola: la del «santo laico» que ha prevalecido como denominador común de algunos reformadores de la España contemporánea, quienes, ante el ocaso de las creencias tradicionales, habilitaron una nueva religión racional y sin dogmas, pero con estrictos principios de comportamiento.

Palabras clave: Francisco Giner de los Ríos; Antonio Machado; mística; panteísmo.

\begin{abstract}
The necrological poem that Antonio Machado dedicates to Francisco Giner de los Ríos is a moral portrait of the honoree, but also a projection of the personality of the poet, who lends his voice for the dead man to expose to his disciples the core of his doctrine. The theme of the composition constitutes an ethical model in which two moral proposals are conflated into a single one: that of the "secular saint», which has

1. Este artículo es una revisión de «Panenteísmo y mística activa en Antonio Machado (sobre "A don Francisco Giner de los Ríos")», capítulo de mi libro La lira de Arión: de poesía y poetas españoles del siglo XX, Alicante, Universidad de Alicante, 1991, pp. 55-84. Elimino de él algunas referencias preliminares a la filosofía krausista, y mantengo el grueso del comentario, con las matizaciones que he creído pertinentes. Dada su condición de reedición, aunque revisada, de un texto ya publicado, con el que he pretendido sumarme al homenaje a Giner, no ha podido seguirse en este caso el método de selección mediante pares ciegos al que se han sometido las restantes colaboraciones del presente volumen.
\end{abstract}


prevailed as a common denominator among some of the reformers of contemporary Spain, who, facing the decline of traditional beliefs, enabled a new rational religion without dogmas, but with strict principles of behaviour.

Keywords: Francisco Giner de los Ríos; Antonio Machado; mysticism; pantheism.

\section{Propuestas tras un derrumbe}

Desde mediados del XIX, el consolador universo de la fe amenazaba derrumbe, sin que la anquilosis de las religiones positivas pudiera responder a la desorientación provocada. Sin embargo, la heterodoxia religiosa, y hasta el ateísmo militante, precisaban para su expresión literaria una vinculación funcional a esas creencias desvitalizadas. Los edificios doctrinales en construcción obedecían aún a las necesidades que cubría la vieja religiosidad. En España, los cascotes del desmoronamiento llegarían hasta la época modernista. En palabras de Ricardo Gullón, a los escritores del momento (Unamuno y Ángel Ganivet, Antonio Machado y Juan Ramón, Azorín y Baroja) «[1] a burocratización de las religiones y la erosión de las creencias les dejó desamparados frente a la muerte» (en Castillo, 1968: 378). Y así como en la Antigüedad la presencia de los dioses y, en general, de lo sobrenatural e inexplicable hundía al hombre en un estado de thambos, estupor provocado por el asedio de seres o instancias superiores (Festugière, 1944: 41-42), en este momento histórico el thambos ya no tiene aquel sentido primigenio: no serán los dioses, sino su ausencia, el motivo de la zozobra. A los embates que sufría un mundo zarandeado, a veces caprichosamente, por fuerzas divinas, sucede ahora un silencio planetario, un territorio espiritual vacío.

En esta situación, la penetración española del krausismo, en la segunda mitad del Ochocientos, supuso el injerto de un espiritualismo racionalista, basado en un sistema de integraciones, en el tronco de una religiosidad en crisis y de una estructura social necesitada de renovación. Sobre el soporte de Fichte, Schelling o Hegel, este sistema de armonización se alejaba del sensualismo como negación de lo ultrasensible, del materialismo como negación del espíritu, del idealismo que supusiera —y solamente de éluna negación de la realidad exterior, del fatalismo como negación de la libertad y, finalmente, del ateísmo como negación de Dios. Y así como el krausismo recaló ferazmente en España, al punto de que casi podría decirse que se hizo en España, sus ecos son perceptibles mucho tiempo después de su repliegue oficial, como lo muestra el poema de Antonio Machado «A don Francisco Giner de los Ríos». 
Sanz del Río, tan importador como, etimológicamente, inventor del krausismo, había propiciado una regeneración moral que no pasaba por la revolución ni los cambios forzados, sino por la colaboración con la historia. En cambio sus discípulos, urgidos favorablemente por los acontecimientos de la Gloriosa en 1868 y una vez desaparecido el maestro en 1869, no se limitaron a allanar las dificultades, sino que quisieron acelerar el curso natural de su meliorismo, ocupando rectorados o ministerios, en marcha hacia el mundo de universal armonía al que aspiraban. Con la Restauración, roto el espejismo de la utopía racional y desalentados, desperdigados o recluidos en el ostracismo los primeros krausistas, los más constantes pasaron, algunos de grado y otros resignadamente, a la acción pedagógica. La ILE (1876) marca ya un periodo de decadencia, donde el racionalismo armónico termina contaminado de positivismo cientificista, dando paso al krausopositivismo, especie de alianza contra natura que trata de acomodar el idealismo krausista al signo de los tiempos. Es la época en que la doctrina es sustituida por el ejemplo, y la metafísica en que consistía se convierte en una ancilla ethicae (Rodríguez de Lecea, 1982: 60). De ese ejemplo moral, difundido mediante la colonización krausista, hizo la caricatura Menéndez Pelayo, subrayando su condición de fruto de una logia francmasónica, fratría o secta:

Se ayudaban y se protegían unos a otros; cuando mandaban, se repartían las cátedras como botín conquistado; todos hablaban igual, todos vestían igual, todos se parecían en su aspecto exterior, aunque no se pareciesen antes, porque el krausismo es cosa que imprime carácter y modifica hasta las fisonomías, asimilándolas al perfil de D. Julián o D. Nicolás. Todos eran tétricos, cejijuntos, sombríos; todos respondían por fórmulas hasta en las insulseces de la vida práctica y diaria; siempre en su papel; siempre sabios, siempre absortos en la vista real de lo absoluto (1956: 1091).

Imposible resulta imaginar la obra teorética de Sanz, y su concepción misional de la enseñanza, sin tener en cuenta el fervor religioso. Para estos utopistas, la recreación de Dios en la vida de los hombres configuraba la historia humana como curso de perfeccionamiento que comienza en la edad simple, en que brilla lo germinal y la pureza mágica del paraíso primigenio, pasa por la edad opositiva y culmina en la edad armónica, con el ingreso del hombre en la «ciudad de Dios en la tierra». El impulso teológico pretendía integrarse sin violencia en el cristianismo, al margen del panteísmo hegeliano: el referido fervor no se detiene en la filantropía o el amor al prójimo, sino que incluye la oración a Jesús y la comunión frecuente. 
El nunca suficientemente aclarado panenteísmo krausista acogía en su seno idealismo germano y cristianismo latino, racionalismo y mística activa, ascetismo e iluminismo. La creencia en un Ser Absoluto no muy distinto del Ser Supremo de la Ilustración dieciochesca, situado sobre la realidad mundanal, les hace equidistar tanto del teísmo (disociación Diosmundo) como del panteísmo (confusión Dios-mundo); o, lo que viene a ser igual, los lleva a participar de uno y de otro, manteniendo cierta concepción dual propia del teísmo, pero sobre una integración del ente divino en la realidad cósmica, sin llegar a la fusión panteísta. En este orden de cosas, las religiones positivas eran entendidas por los krausistas como un paso intermedio en un proceso evolutivo de perfeccionamiento. En el umbral de la plenitud, pretendían salvar lo que las religiones históricas tienen de valor, particularmente el sentimiento de amor universal del cristianismo. Poco a poco fue asentándose la idea de una religión racional, que antes de los ataques furibundos de los impugnadores integristas podía asimilarse al cristianismo sin problemas (mucho más difícilmente al catolicismo incluso entendido de manera liberal). Esta religión había de ser compatible, primero, con la razón; segundo, con la libertad humana. Para un krausista de la primera hornada como Giner, núcleo de estas páginas y del poema de Antonio Machado del que se ocupan, «no hay ni puede haber género alguno de antagonismo entre la Religión del Mesías y la libertad fundada por ella sobre bases indestructibles» (1922: 326). Otra cosa era la ganga litúrgica (rituales, milagrería, jerarquías eclesiales) y el conjunto de adherencias dogmáticas y formales que convirtió el cristianismo, en cuanto doctrina moral de Jesús, en su desviación católica, eclesiástica, formularia y rígida. Aunque tampoco conviene extremar parecidos y minimizar disensiones, como hace Alain Guy refiriéndose a Sanz del Río cuando escribe que «cabe preguntarse si no sería simplemente que iba adelantado a su tiempo y si el Concilio Vaticano II no hubiera aceptado la mayor parte de sus tendencias» $(1985: 253)^{2}$.

Ello así, es lógico pensar que las relaciones entre el hombre y ese Ser Supremo que no precisaba de tramoya milagrosa ni aparato litúrgico,

2. La consideración del krausismo como un catolicismo más o menos desprovisto de su coraza dogmática decimonónica es muy habitual; así, en A. Jiménez-Landi puede leerse: «Los deseos de don Fernando [de Castro] y las palabras de don Julián, que parecían heréticas hace cien años, y, sin duda, se pronunciaban con intenciones poco ortodoxas, hoy, no obstante, resultan una profecía. Lo peor para las mentes reaccionarias, y aun para la misma Iglesia, es que los profetas del Concilio Vaticano segundo hayan sido, en parte, precisamente los heterodoxos» (1973: 158). 
deberían establecerse libremente y de modo directo, como una conexión íntima que se produjera, en la pretensión de Sanz del Río, en la conciencia del hombre. Algo, por cierto, que queda muy cerca de la «Profesión de fe» del vicario saboyano en el Émile (1762) de Rousseau, un referente no solo educacional para los profesores institucionistas: la figura de Jesucristo aparece como canon en la medida en que es portador de una contrastada belleza moral, a la que Sócrates, por ejemplo, solo se acerca3; y el Evangelio, pese a estar poblado de cosas increíbles que repugnan a la razón humana, ensombrece a los libros de los filósofos. Un poco más allá y tenemos la religión de Fernando de Castro, a quien con tanta crueldad trató Menéndez Pelayo, el cual se chancea (luego de muerto y, según el airado santanderino, condenado) del antiguo clérigo reducido al estado seglar cuando proponía una Iglesia universal con un culto sincrético, cuyos sacerdotes serían los ancianos y sus santos los fundadores de religiones y hombres famosos, de Buda a Sócrates, de Zoroastro a Lutero, de San Agustín a Fénelon, de Séneca a Cervantes, de Marco Aurelio a Santa Teresa, de Cristo a Copérnico (1956: 1161).

Aceptando sin reservas la sinceridad religiosa de los krausistas, parece que el catolicismo liberal era solo un paso, más breve de lo que hubiera resultado sin la intransigencia eclesiástica, que no se detenía ahí, sino que conducía al alejamiento del estricto catolicismo. Resulta en cierto modo patético el inicial afán krausista por conciliar razón y fe; un anhelo que, en cuanto tal, presenta algún parecido, por su esforzado voluntarismo, con el intelectualismo tomista. Pero, pujante la doctrina novísima, la Iglesia católica se encargó de enconar las posturas: el inconcluso Concilio Vaticano I (1869-1870) convocado por Pío IX proclamó el dogma de la infalibilidad papal, fijó las relaciones entre razón y fe, definió la revelación y atacó el racionalismo; y el racionalismo y el panteísmo fueron dos de

3. «Cuando Platón pinta a su justo imaginario cubierto por todo el oprobio del crimen y digno de todos los premios de la virtud, pinta rasgo a rasgo a Jesucristo, el parecido es tan sorprendente que todos los Padres lo han percibido y es imposible engañarse en ese punto. ¡Qué prejuicios, qué ceguera no hay que tener para osar comparar el hijo de Sofronisco con el hijo de María! ¡Qué distancia del uno al otro! [...] La muerte de Sócrates filosofando tranquilamente con sus amigos es la más dulce que se pueda desear; la de Jesús expirando en los tormentos, injuriado, burlado, maldecido por todo un pueblo es la más horrible que se pueda temer; al tomar la copa envenenada Sócrates bendice a quien se la presenta y que llora; en medio de un suplicio horroroso, Jesús ruega por sus encarnizados verdugos. Sí, si la vida y la muerte de Sócrates son de un sabio, la vida y la muerte de Jesús son de un Dios» (Rousseau, 1990: 417). 
los errores establecidos también por el primer Syllabus (1864), inspirado asimismo por el citado Papa.

Se ha afirmado en repetidas ocasiones que, sin la hostilidad sufrida por los representantes del krausismo, este apenas hubiera dejado rastro de su paso. No creo que sea cierto, como sí lo es el que, fruto de esa hostilidad, se precipitara el divorcio definitivo con la Iglesia católica y acabara la ilusión conciliadora de catolicismo y libertad individual. Algunos krausistas expresaron angustiadamente sus contradicciones, avances y retrocesos. Así, Gumersindo de Azcárate afirma en su Minuta de un testamento, palpitante autobiografía espiritual: «yo podía continuar rezando el Padre Nuestro, que aprendiera de labios de mi inolvidable madre; pero no podía recitar aquel Credo que también ella me enseñara, pero que definitivamente no era ya el mío» (1876: 32). Entre actitudes como esa y las de otros más extremistas, como Fernando de Castro, que se refiere al Papa como Vicedios en la tierra, las posturas más frecuentes fueron las de quienes abandonaron el dogma católico como resultado de los avances del positivismo; un positivismo que, al cabo, resultaba tan opuesto al catolicismo doctrinal como al romántico idealismo krausista. Sirva de ejemplo el del penalista de la Universidad de Salamanca Dorado Montero, quien, en una carta que remite a Federico Urales, tras elogiar la flexibilidad con que trataba Giner en sus clases de Filosofía del Derecho el tema del catolicismo, viene a concluir serenamente que la propia cultura, las lecturas sin más, le han hecho perder la fe (en Urales, 1977: 93-94)4. Y no deben extrañar los ires y venires de tantos seguidores de Sanz del Río cuando el propio Sanz, ante el hostigamiento de Ortí y Lara y de Aparisi y Guijarro, que lo acusaban de panteísta y corruptor de la juventud estudiosa, llega a proclamar su plena ortodoxia católica («Carta y cuenta de conducta», 1865).

Tal vez el punto más brumoso de la religiosidad krausista sea la actitud ante la inmortalidad individual. Parece que las vagas referencias a una reintegración cósmica de naturaleza panteísta, considerada como mera engañifa por Unamuno, no solventaron la angustia personal de muchos de ellos. De cualquier forma, el aspecto teórico del pensamiento sobre la

4. Federico Urales (pseud. de Juan Montseny) solicitó a diversos intelectuales (Pompeyo Gener, Unamuno, Santiago Rusiñol, Juan Maragall, Eduardo Marquina, Dorado Montero, etc.) que especificaran sus raíces culturales y los escritores que les habían influido más. El objetivo de tales consultas era la redacción de La evolución de la filosofía en España, que publicó en Revista Blanca entre 1900 y 1902. Una parte de ese estudio (la que arranca de los orígenes del socialismo español) se recoge, con idéntico título, en el volumen citado (Urales, 1977). 
religión —si esta es ligazón entre hombre y Dios, hombre y naturaleza, hombre y otros hombres - se encuentra necesariamente orientado a lo moral, lo mismo que la filosofía de la historia o que la lógica, que la epistemología o que la estética. Todas esas y otras disciplinas adquieren pronto entonación prescriptiva y una indisimulable vertiente ética.

\section{El Giner de Antonio Machado}

Sobre esta conexión entre inmortalidad individual y dechado moral versa el poema necrológico que dedicó Antonio Machado a don Francisco Giner de los Ríos. Convengamos en que su interés es doble: permite un acercamiento a Giner a través de la semblanza trazada por uno de sus conocedores más cercanos, y, al lado, nos da acceso al hombre que lo escribió. La afirmación de Unamuno de que el biógrafo termina escribiendo siempre su autobiografía es más que una boutade; un ejemplo lo ofrece este poema, donde se produce la confluencia, me parece, entre ambas figuras: la de Antonio Machado y la de Francisco Giner de los Ríos.

El poema, cuyo pie reza «Baeza, 21 de febrero de 1915», apareció publicado el 26 de febrero en la revista España. No se demoró mucho tiempo Machado en componerlo: Giner había muerto el 18 de febrero. El hecho de que pueda confrontarse, y no solo a efectos de interpretaciones dudosas, con una necrológica en prosa que Machado publicó en el baezano Idea Nueva el 23 de febrero de 1915, ofrece un interés añadido al texto lírico, en el que se entreveran la semblanza humana del muerto y la exposición de ideas religiosas y morales de índole krausista, filtradas ambas en el tamiz del autor.

La relación de Machado con Giner había comenzado muy temprano. $\mathrm{Su}$ abuelo, don Antonio Machado y Núnez (naturalista y difusor del darwinismo en España), y su mismo padre, don Antonio Machado y Álvarez, el folclorista Demófilo, fueron activos proinstitucionistas. Con el traslado a Madrid del abuelo, seguido por toda la familia, Manuel y Antonio Machado pasaron a estudiar en la Institución Libre de Enseñanza, asunto del que hay mucho dicho (AA. VV., 2012-2013) y en el que no vamos a profundizar aquí. Antonio cursó allí sus estudios desde 1883 hasta 1888. Su relación afectiva con la Institución, frente a la confesada aversión al Instituto y a la Universidad, queda explicitada en una nota que escribió a comienzos de 1913:

Me eduqué en la Institución Libre de Enseñanza y conservo gran amor a mis maestros: Giner de los Ríos, el imponderable, Cossío, Caso, Sela, 
Sama (ya muerto), Rubio, Costa (D. Joaquín —a quien no volví a ver desde mis nueve años-). Pasé por el Instituto y la Universidad, pero de estos centros no conservo más huella que una gran aversión a todo lo académico (Machado, III, 1988: 1524).

En parecidos términos se expresa en una carta a Juan Ramón Jiménez escrita por las mismas fechas (ibid.: 1521). Todavía el consejo de Giner llevaría a Machado a abandonar su proyecto de colocarse en el Banco de España y a preparar oposiciones a cátedras de institutos en la disciplina de francés.

Pero vayamos ya al poema (Machado, II, 1989: 587-588), el CXXXIX de la reunión de sus poesías completas:

Como se fue el maestro,

la luz de esta mañana

me dijo: Van tres días

que mi hermano Francisco no trabaja.

5 ¿Murió?... Solo sabemos

que se nos fue por una senda clara,

diciéndonos: Hacedme

un duelo de labores y esperanzas.

Sed buenos y no más, sed lo que he sido

10 entre vosotros: alma.

Vivid, la vida sigue,

los muertos mueren y las sombras pasan;

lleva quien deja y vive el que ha vivido.

¡Yunques, sonad; enmudeced, campanas!

15 Y hacia otra luz más pura

partió el hermano de la luz del alba,

del sol de los talleres,

el viejo alegre de la vida santa.

...Oh, sí, llevad, amigos,

20 su cuerpo a la montaña,

a los azules montes

del ancho Guadarrama.

Allí hay barrancos hondos

de pinos verdes donde el viento canta.

25 Su corazón repose

bajo una encina casta,

en tierra de tomillos, donde juegan

mariposas doradas...

Allí el maestro un día

30 soñaba un nuevo florecer de España. 
La composición fue incluida por Machado en la versión ampliada de Campos de Castilla que aparecería en sus Poesías completas de 1917. Es mucho más, desde luego, que un mero poema de circunstancias, según lo parecen otros de la serie «Elogios» que encabeza, en la que ensalza a escritores como Azorín, Juan Ramón, Valle-Inclán, Rubén, Ortega o Unamuno.

Del talante espiritual de Giner solo vamos a hablar aquí al trasluz de los versos de Antonio Machado. Si queremos asomarnos excepcionalmente fuera, no lo haremos atendiendo a los testimonios de sus discípulos, fervorosos y concluyentes, sino al de Menéndez Pelayo, tan poco dado a la indulgencia con cuantos intelectuales olieran algo a krausismo, y tan especialmente áspero con Sanz del Río, Salmerón y Fernando de Castro. Pues bien, el polígrafo cántabro resulta parcamente contemporizador con Giner, de quien resalta su capacidad propagandista, pues podía «convertir en krausistas hasta las piedras; hombre honradísimo por otra parte, sectario convencido y de buena fe» (Menéndez Pelayo, 1956: 1163).

Los versos reproducidos aluden, claro, a la muerte de Giner; sin embargo, no estamos ante un poema fúnebre o elegiaco, ni aparece en él tratada la muerte con las habituales notas de aflicción y abatimiento. Por el contrario, ella da plenitud a la vida del maestro, al tiempo que plantea una exigencia moral a quienes quedan en la tierra: la del trabajo, la de la pureza, la de la bondad, la de la esperanza en una patria mejor, según la hermosa utopía hispanokrausista de dignificación de la vida española y mejoramiento del mundo.

El poema, silva arromanzada con sencillas asonancias á-a en los versos pares, no presenta «apartados» cerrados, pero tiene diversos tramos distinguibles a lo largo de sus treinta versos. Tras el comienzo (vv. 1-4), con una referencia indirecta a la muerte del maestro, los versos siguientes (5-14) recogen las reflexiones de Machado y la propia propuesta moral de Giner. Desde el verso 15 se exponen los pensamientos de Machado, que alude en el mismo plano al cuerpo del maestro fallecido, al paisaje que amó y donde se propone que sea enterrado, y, en fin, a la regeneración de España soñada por aquel.

Por las circunstancias que motivaron el poema, y aun por tratar este un asunto filosófico como el de la trascendencia individual, es central la referencia a la muerte. Sin embargo, no hay nada de la tanatofanía católica, con su aparatosa espectacularidad («Sic transit...»); por el contrario, «A don Francisco Giner de los Ríos» es un poema vitalista, de incitación a la existencia en plenitud. La lobreguez de la muerte está alumbrada por una luz que refulge, y hasta el propio término muerte está soslayado. La de don 
Francisco no ocurre en el poema: ocurrió antes, y el «murió» se convierte en un «se fue» (v. 1). Por lo mismo, en el verso 4 accedemos a una afirmación que debe leerse más allá de su epidermis: «mi hermano Francisco no trabaja». Lo mismo da decir que el hermano Francisco ha muerto, pero, sobre la elusión del término muerte, se eleva ahora una primera propuesta moral: trabajo igual a vida.

El vitalismo del poema está emparentado con el espíritu del franciscanismo, que lo permea por completo: alegría, austeridad, castidad, limpieza de alma... El tratamiento dado al «hermano Francisco» del comienzo, quien es, a su vez, «hermano de la luz del alba, / del sol de los talleres», nos conduce a un universo de amor y sencillez, de comunicación con la naturaleza, en una suerte de laus criaturarum... Todo ello nos recuerda, es evidente, al otro hermano Francisco, «il poverello d'Assisi», más atento al ejercicio cordial que a las acartonadas rigideces teológicas.

El poema va desgranando un largo muestrario de iluminaciones y chispazos religiosos y morales: luz epifánica y claridad solar (vv. 2, 6, 15, 17) como camino de elevación (v. 20). A la luz y a la altura se accede mediante la misma operación del espíritu humano. Al lado, asimilación de vida a trabajo (vv. 3-4), bondad (v. 9) como componente esencial del espíritu (v. 10), vitalismo que huye del regodeo funeral (vv. 11-14), pureza (v. 26), fraternidad (vv. 4, 16-17, 19), alegría (v. 18), magisterio (vv. 1, 29). Pese a su aire espiritual, nada hay en el poema que recuerde esa cuestión religiosa con cuya presencia «el alma española suena a cartón piedra» (Machado, III, 1988: 1519).

Son tres los pilares que sostienen el peso de los versos: 1) muerte sustraída a las notas con que habitualmente se nos presenta; 2) tendencia a hacer el bien como término de sí mismo, sin interesada búsqueda de un premio ulterior; y 3) espíritu globalizador que fusiona o re-liga —religiosamente - individuo, naturaleza y coro humano. ¿Qué relación guardan estos tres pilares con la doctrina krausista? En Ideal de la humanidad para la vida, una obra donde Julián Sanz del Río reconduce y recrea con su pluma el original de Krause, figuran unos «Mandamientos de la humanidad» que fueron lo más leído - y en muchos casos lo único entendido- de su autor (López-Morillas, 1980: 82-83). De estos mandamientos, especie de grageas que condensan las lecciones del maestro, unos son generales y otros particulares. Fijémonos, por lo que respecta a nuestro propósito, en dos de ellos. Reza así el segundo (de los generales):

Debes conocer, amar y santificar la naturaleza, el espíritu, la humanidad sobre todo individuo natural, espiritual y humano (Krause, 1860: 100). 
Y el decimotercero, primero a su vez de los particulares «y prohibitivos»:

Debes hacer el bien, no por la esperanza, ni por el temor, ni por el goce, sino por su propia bondad: entonces sentirás en ti la esperanza firme en Dios y vivirás sin temor ni egoísmo y con santo respeto hacia los decretos divinos (ibid.).

La primera de las referidas tres ideas-clave conecta estrechamente con la tercera. Una se cierra en la otra circularmente. La muerte no es desintegración en la nada, sino que alimenta a la vida; el hombre revierte en la naturaleza. Los elementos del mundo natural aparecen henchidos de divinidad, y de humanidad también, en una mostración de la pathetic fallacy: la luz habla y llama hermano a Francisco; el viento canta; la encina está vestida con atributos de castidad; las mariposas de oro juegan en tierra de tomillos. El poema brilla con ese encendimiento prosopopéyico de los elementos naturales, que configuran el espacio sagrado donde debe descansar Giner. Los epítetos crean una atmósfera de desnudez y autenticidad, precisamente en tanto que depuran sin añadir nada desde un ángulo puramente representativo: hondos barrancos, verdes pinos. La naturaleza se señala con sustantivos referidos al mundo de las realidades elementales: río, sierra, barranco, encina. Junto a los sustantivos, adjetivos de sencillo cromatismo: azules montes, pinos verdes, mariposas doradas. Antes de que los dos versos finales ( Allí el maestro un día / soñaba un nuevo florecer de España») cierren el poema con su aliento regeneracionista y nos desciendan al corazón de la patria y de los otros hombres, en esos paisajes de pureza que tanto amó el maestro se produce la reintegración, una particular forma de unión en una naturaleza animada: volver a la tierra para cerrar - y proseguir - el ciclo de la vida.

El esbozo de este territorio animado tiene mucho en común con el locus amonus, por lo que hace al espacio, pero también con un illud tempus no retrospectivo a lo lejos, como es lo usual, sino prospectivo y profético. Paraíso y edad de oro. El paraíso conoce numerosas expresiones literarias, pero suele presentarse como encuentro y fusión armónica; así en las profecías bíblicas $^{5}$. El franciscanismo hermana las fuerzas enemigas en la vigorosa literatura de Isaías, mucho antes de la entrada en escena de los fraticelli. Y aunque la edad de oro se sitúa generalmente, como hemos

5. «Habitará el lobo con el cordero, / y el leopardo se acostará con el cabrito, / y comerán juntos el becerro y el león, / y un niño pequeño los pastoreará» (Is 12, 6). En 62, 25 algo similar: «El lobo y el cordero pacerán juntos; / el león, como el buey, comerá paja, / y la serpiente comerá polvo». 
señalado, en el pasado remoto a la manera hesiódica, aquí la bondad, la verdad y la belleza son proyección del presente hacia el futuro mejor. Mediante el mejoramiento progresivo hacia el porvenir utópico: así es la corriente de pensamiento krausista que nutre la composición.

Siguiendo con ambos bastiones de significado (ideas primera y tercera: muerte arrancada a la muerte; y fusión entre individuo, naturaleza y coro humano), cabe preguntarse por el tratamiento que el poema presta a la inmortalidad individual. Aunque no directas, sí hay alusiones a ello, que pueden contrastarse, además, con el artículo necrológico que Machado escribió en los días siguientes a la muerte de Giner, y que en algunos párrafos parece un guion escrupulosamente tenido en cuenta para redactar el poema.

En los versos 5 y 6 tenemos una primera clave: «¿Murió?... Solo sabemos / que se nos fue por una senda clara». Como no se trata aquí de la muy palmaria muerte física, y tampoco nos hallamos ante una pregunta retórica (que sería más inane que inocua), hay que concebir la pregunta en un nivel de trascendencia: «¿Murió?» Esto es: ¿Ha muerto definitivamente? La religiosidad natural pensaba en un dios como sustancia espiritual de la naturaleza, pero no parece que sea solo un vago panteísmo, sin respuesta positiva acerca de esa inmortalidad individual, el que explique sin más el encogimiento de hombros con que Machado responde a la pregunta que él mismo formula: "Solo sabemos...». Y tampoco parece únicamente desdén de Machado hacia las formulillas adormecedoras de la Iglesia católica aplicadas de manera mecánica ${ }^{6}$. Ni únicamente desdén, ni únicamente serenidad ante la reintegración panteísta, el «Solo sabemos...» apunta a la ignorancia real del destino humano y, con ello, a la certidumbre ética de que ese destino no debe condicionar la vida del hombre.

6. En esa especie de currículum que citábamos atrás, y que escribió el poeta a comienzos de 1913, afirma Machado: «Estimo oportuno combatir a la Iglesia católica y proclamar el derecho del pueblo a la conciencia y estoy convencido de que España morirá por asfixia espiritual si no rompe ese lazo de hierro». Líneas más abajo, concluye: «Admiro a Costa, pero mi maestro es Unamuno» (Machado, III, 1988: 1525). Esta referencia admirativa a Unamuno, y las numerosas que le dedicó en otras ocasiones, pueden hacer pensar que lo que ataca Machado, en la línea del vasco, no es tanto el dogma católico cuanto la inercia espiritual engendradora de hipocresía, conformismo y «falta de virilidad espiritual» (ibid.). 


\section{Significado de un emblema}

El poema cede en este punto la voz al muerto (vv. 7-14), en lo que podemos considerar su testamento ideológico (claro que redactado por Machado, el autor-demiurgo). Tras la invitación al trabajo, Giner propone como norma de conducta — segunda idea nuclear a que antes nos hemos referido, y decimotercer mandamiento de Ideal de la humanidad - la persecución del bien en sí mismo: «Sed buenos y no más» (cursiva mía); nada importa el provecho o la falta de provecho que de ello se desprenda. Pero el corazón de la composición está en los versos 11-14, y, dentro de ellos, en el 13:

Vivid, la vida sigue,
los muertos mueren y las sombras pasan;
lleva quien deja y vive el que ha vivido.
¡Yunques, sonad; enmudeced, campanas!

No nos detendremos en la incitación más evidente: la de honrar al muerto mediante la vida laboriosa (símbolo positivo: yunque, glorificación del trabajo como insignia moral), no mediante el lamento esterilizador (símbolo negativo: campana, ostentación luctuosa del dolor); ni siquiera en una algo menos obvia ( «Vivid, la vida sigue, / los muertos mueren...») que remite a una formulación evangélica («deja a los muertos enterrar a sus muertos», Mt 8, 22; Lc 9, 20). Detengámonos, más bien, en el verso 13: «lleva quien deja y vive el que ha vivido». Exactamente, ¿cuál es el significado de este emblema?

Veámoslo así: sobre lo incierto de la otra vida, al hombre contingente solo le es dado actuar en esta; única o no, nuestra capacidad de acción se ciñe al ahora, de modo que la hipotética posesión futura se nutre de lo que cosechamos en el presente. Si hubiera que granjearse por merecimiento algún futuro, este es el único camino ${ }^{7}$; pero si no fuera así, igualmente el hombre debería actuar, y actuar «igualmente» (tal que si sus hechos hubieran de hacerlo acreedor a ese premio inexistente), contraído al único ámbito en el que su acción cobra sentido y se agota. Lo cual nos remite a Senancour y su Obermann, en una reflexión traída a colación a menudo por Unamuno: «si la nada nos está reservada, hagamos que sea una injusticia» (carta XC). Pero ello es así no por una vaga idea estoica que, como en la

7. En esta línea se pronuncia Fernando de Castro en su Memoria testamentaria (1874), publicada póstumamente, en la que da cuenta de su particular credo religioso, y donde afirma, tras pedir que no intervenga clérigo alguno en sus exequias: «estoy persuadido de que lo que más recomienda el alma a Dios, no son los rezos y las misas del sacerdote, sino las buenas obras que se hubieren hecho en vida» (en Jiménez-Landi, 1973: 400). 
novela alpina de Senancour, obliga a una resistencia independiente de lo que haya al cabo, como el soldado que queda en pie dentro de su armadura ya muerto; sino porque en el ideal ético krausista el bien — punto segundo al que nos vamos a referir pronto- se autojustifica, sin proyectarse interesadamente en otra cosa. En suma, si solo se posee como un mérito aquello que se ha ofrecido como una desinteresada donación, entonces «lleva quien deja», tiene el que da. Y, por ende, «vive el que ha vivido»: vive (un presente proyectado al futuro: vivir la vida tras la muerte, si es que existe esa vida; vivir la vida presente, si es la única) quien ha vivido esta sin considerarla mero objeto de transacción.

El poeta ha usado, para marcar las insistencias, de las fórmulas paralelísticas («la vida sigue», «los muertos mueren», «las sombras pasan»; enseguida: «lleva quien deja», «vive el que ha vivido»), para concluir en un quiasmo: «iYunques, sonad; enmudeced, campanas!». Los imperativos, ahora como antes (Hacedme, Sed, Vivid, sonad, enmudeced), son expresión pedagógica de la lección del maestro. El estilo apretado del poema se esponja en la semblanza necrológica publicada en Idea Nueva (Machado, III, 1988: 1575-1577):

... Y hace unos días se nos marchó, no sabemos adónde. Yo pienso que se fue hacia la luz. Jamás creeré en su muerte. Solo pasan para siempre los muertos y las sombras, los que no vivían la propia vida. Yo creo que solo mueren definitivamente - perdonadme esta fe un tanto herética一, sin salvación posible, los malvados y los farsantes, esos hombres de presa que llamamos caciques, esos repugnantes cucañistas que se dicen políticos, los histriones de todos los escenarios, los fariseos de todos los cultos, y que muchos cuyas estatuas de bronce enmohece el tiempo, han muerto aquí y, probablemente, allá, aunque sus nombres se conserven escritos en pedestales marmóreos.

De la índole moral de Giner afirma en el mismo artículo Machado:

Era don Francisco Giner un hombre incapaz de mentir e incapaz de callar la verdad; pero su espíritu fino, delicado, no podía adoptar la forma tosca y violenta de la franqueza catalana, derivaba necesariamente hacia la ironía, una ironía desconcertante y cáustica, con la cual no pretendía nunca herir o denigrar a su prójimo, sino mejorarle. Como todos los grandes andaluces, era don Francisco la viva antítesis del andaluz de pandereta, del andaluz mueble, jactancioso, hiperbolizante y amigo de lo que brilla y de lo que truena. Carecía de vanidades, pero no de orgullo; convencido de ser, desdeñaba el aparentar. Era sencillo, austero hasta la santidad, amigo de las proporciones justas y de las medidas cabales. Era un místico, 
pero no contemplativo y extático, sino laborioso y activo. Tenía el alma fundadora de Teresa de Ávila y de Íñigo de Loyola; pero él se adueñaba de los espíritus por la libertad y por el amor.

Era —lo dice Machado- un místico «laborioso y activo», cuyo ejercicio espiritual provoca elevación, sublimación de la materia, donación a los hombres. En otras palabras: el amor como término de sí mismo (segunda idea sustantiva del poema).

En efecto, tras la invitación al trabajo («Hacedme / un duelo de labores y esperanzas»), Giner ha señalado como norma de conducta la persecución desinteresada del bien («Sed buenos y no más»), incluso poniéndose a sí mismo como dechado ( «sed lo que he sido / entre vosotros: alma»). Dicho en primera persona, esto puede interpretarse como jactancia, o al menos como expresión del «orgullo modesto, que es lo español y lo cristiano» que aconsejaba el apócrifo Juan de Mairena a sus alumnos, si no fuera porque constituye una deriva de la voz del poeta hacia el psiquismo de quien está hablando; en otras palabras, un elogio que formula Machado sobre Giner y que canaliza en la voz del propio Giner, así autoelogiado. (Juzgue cada quien si lo que se gana en inmediatez conativa con la primera persona compensa lo que se pierde en imagen de la humildad que se pretende conseguir; yo pienso que no).

En realidad, este ejercicio espiritual es más devocional que propiamente místico. En su oscilante vinculación entre la bondad utilitaria y la bondad desinteresada, la literatura espiritual española ha bandeado entre ortodoxia y heterodoxia. El bien por el bien como precepto de Dios: esta máxima de Krause («perogrullada» la llama Menéndez Pelayo, que la adscribe sin más a la ética kantiana) es de raigambre estrictamente cristiana, sin que quepan en esto reservas como las que expresa el referido autor cuando afirma que tal fórmula sería en efecto cristiana, «y de las más corrientes si no supiéramos lo que significa la palabra Dios en todo sistema panteístico» (Menéndez Pelayo, 1956: 1081). Un fuerte curso religioso había recogido las brasas sanjuanistas hasta llegar a predicar la indiferencia absoluta con respecto a cualquier bien, no ya solo futuro y alcanzable, sino presente: la sumisión a la divinidad exigía total independencia espiritual con respecto a la pulsión de salvación. Esto adquiere sublimación espiritual en el soneto «A Cristo crucificado» del Siglo de Oro, cuyo anónimo autor, que asume la ortodoxia católica a los efectos teóricos, desvincula de aquella su comportamiento moral, dominado por una simpatía pietista que expresa su amor al Cristo doliente al margen de premios o castigos: «No me mueve, mi Dios, para quererte / el cielo que me tienes prometido; 
/ ni me mueve el infierno tan temido / para dejar por eso de ofenderte»...; con el corolario de la determinación de amar a Jesús no ya sobre todas las cosas, sino al margen de todas las cosas: «pues aunque cuanto espero no esperara, / lo mismo que te quiero te quisiera» (en Blecua, 1987: 175176). Recordemos también, por contraste, las Coplas manriqueñas, en las que se encarece el buen comportamiento como pago para la obtención del premio de la vida futura.

Pero el desprendimiento de los intereses, manifestado tanto en «A Cristo crucificado» como en la semblanza machadiana de don Francisco Giner, tiene una larguísima tradición en la literatura de los espirituales de varias épocas: el Maestro Eckhart, y Taulero, y San Juan de la Cruz, y Miguel de la Fuente, y Miguel de Molinos... Angelus Silesius (Johann Scheffler), autor de El querubín peregrino, encerró en su célebre aforismo sobre la rosa esa manera de obrar que se agota en sí misma: «La rosa es sin porqué, florece porque florece». El molinosismo predicó la doctrina quietista que llevó el despego y la negación del propio interés hasta los extremos que siguen (radicalizada versión del «me hice perdidiza, y fui ganada», del Cántico sanjuanista):

Sabrás que se ha de desapegar y negar de cinco cosas el que ha de llegar a la ciencia mística. La primera, de las criaturas; la segunda, de las cosas temporales; la tercera, de los mismos dones del Espíritu Santo; la cuarta, de sí misma, y la quinta, se ha de desapegar del mismo Dios. Esta última es la más perfecta, porque el alma que así se sabe solamente desapegar es la que se llega a perder en Dios, y solo la que así se llega a perder es la que se acierta a hallar (III, 176) .

Con el molinosismo concuerdan los krausistas en el despego y la humildad, pero no en el nihilismo quietista (pues ellos son hombres de acción, si no revolucionaria sí reformadora); y tampoco concuerdan en el odio de sí, que le hace a Molinos afirmar: «No tiene humildad interior el que no se aborrece a sí mismo con un mortal odio, pero pacífico y quieto. No llegará jamás a alcanzar este tesoro el que no tuviere un bajo y profundísimo conocimiento de su vileza, de su hediondez y miseria» (III, 103). Un amor tan negador, en fin, que le llevaría a la misma negación del amor y al más radical abismarse en la nada: «no mires nada, no desees nada, no quieras nada...» (III, 195).

8. Cito especificando «libro» y entrada numérica; sigo la edición de José Ángel Valente (1990). 
La renovación espiritual a que tendían estos idealistas muestra estrechas afinidades con rasgos erasmistas, como son el afán de interiorización y el desdén por las manifestaciones litúrgicas externas ${ }^{9}$, notas patentes en el poema (enmudecimiento de las campanas), y de manera mucho más explícita en la citada necrológica en prosa. Afirma en ella Machado: «Desdeñaba don Francisco Giner todo lo aparatoso, lo decorativo, lo solemne, lo ritual, el inerte y pintado caparazón que acompaña a las cosas del espíritu y que acaba siempre por ahogarlas» (Machado, III, 1988: 1576). Esencia erasmista que recoge —o de la que participa- el krausismo.

El poema camina hacia la integración, como confluencia y desembocadura de las llamadas dispersas a lo largo de la composición. El verso 15 marca una inflexión en el tono, al inicio de ese proceso integratorio: el viejo Giner marcha «hacia otra luz más pura». Aparece ahí entrevista la dualidad, mediante un sistema de correspondencias: luz atenuada por la opacidad del existir, por un lado; luz «más pura», sin obstáculos ni cendales, por otro. Una vez muerto y la tarea cumplida, «el viejo alegre de la vida santa» habita ya la naturaleza divinizada. A partir del verso 19, y tras la solicitación autorial a los amigos de que entierren el cuerpo del maestro en su amada Sierra de Guadarrama, el poema se demora en la descripción anticlimática, y de talante panteísta, de una naturaleza animada, esto es, vertebrada por el soplo creador que hace - ya se ha dicho- que el viento cante, las encinas se invistan de castidad, jugueteen las mariposas (trasunto de la mariposa tricolor que, tras la muerte de Platero, el burrillo

9. Krause y Erasmo no solo coinciden, respecto a su integración cultural en España, en el hecho de que a uno y a otro se les prestara más atención en España que en sus países de nacimiento. También lo hacen en que su pensamiento logró avivar el aletargado talante filosófico español, que en el caso del krausismo terminó propiciando un modo de filosofía «nacional» (Posada, 1981: 25 ss.). Con razonamientos diversos, numerosos autores (Azorín, Fernando de los Ríos, Joaquín Xirau, Eloy Terrón, Elías Díaz, José Luis Abellán, etc.) creen que el krausismo, como antaño el erasmismo, es «español» en la medida en que no solo se ajustaba a las necesidades nacionales de reforma, sino también porque España, al contacto con la doctrina foránea, dio forma a un pensamiento que permanecía en estado latente, lo que quiere al cabo decir que encontró en el krausismo aquello que estaba buscando. La idea de que el pensamiento español «se hizo krausista» por casualidad —o por pereza intelectual de Sanz del Río- procede de Menéndez Pelayo, quien propaló la especie de que Julián Sanz del Río tropezó azarosamente con el krausismo en su viaje de estudios a Alemania, como lo podría haber hecho con cualquier otra corriente de pensamiento. En su incidencia en la religiosidad española, erasmismo y krausismo no coinciden tanto en el corazón doctrinal como en la necesidad, en el XVI igual que en el XIX, de vitalizar una espiritualidad ahogada en ostentaciones litúrgicas, y reprobar la corrupción e hipocresía de las costumbres. 
cuya historia había encandilado al agonizante don Francisco, se irisaba cuando se cruzaba con el rayo solar que se colaba por el ventanuco de la cuadra). Y no deja de ser reseñable, por lo sugerente a unos y por lo enojoso a otros, que la imagen machadiana del nuevo alborear de la patria con que se cierra el poema, al hilo de la particular religión del Guadarrama de la que el maestro Giner era el sumo sacerdote («Allí el maestro un día / soñaba un nuevo florecer de España»), sirviera años después a los poetas fascistas para poetizar la estampa de un país amaneciente donde comenzaba a reír la primavera.

El poema ajusta tensamente la naturaleza de lo cantado a unas palabras que rehúyen las metáforas ostentosas y los bruñidos juegos verbales. Los suaves engarces sintácticos y las frecuentes esticomitias van trenzando un discretísimo encadenamiento - mera enumeración normalmente- de ritmo e ideas. La serenidad de la composición es compatible, sin embargo, con la abundancia de apóstrofes e imperativos, vocativos, exclamaciones: «Sed buenos», «Vivid», «Yunques, sonad; enmudeced, campanas», «Oh sí, llevad, amigos»... Son, todos ellos, elementos acordes con la entonación parenética y exhortatoria de carácter «magisterial», como corresponde a la elevación del canon ético que se propone.

Machado dibuja la etopeya de un texto vivo, cuya ejemplaridad ética arrastra más que los libros en que se expone su doctrina. En estos versos se quintaesencian las estancias plurales de la novísima filosofía krausista (y, por irradiación, gineriana y aun machadiana): amor al trabajo, moralidad radical, tolerancia, espiritualidad en que se hermanan naturaleza y hombre, sencillez franciscana, patriotismo. Gumersindo de Azcárate lo resumía así en Minuta de un testamento, donde daba cuenta de su alejamiento de la Iglesia: "como ideal práctico la vida santa de Jesús, como regla de conducta una moral pura y desinteresada, como ley social el amor y la caridad, como dogma el Sermón de la Montaña, como culto la Oración dominical» (1876: 31-32). Y Sanz del Río, maestro del maestro de Machado, había instado a sus discípulos: «Dejad tras de vuestro nombre un rastro de bellos ejemplos y doctrinas, y una memoria sin tacha».

Tan hermoso ideario encontró, además, un poeta que lo convirtió arte. «A don Francisco Giner de los Ríos» es, por todo lo anterior, un monumento grávido de pensamiento y estremecido de emoción: un poema mayor, sin duda, en la obra de don Antonio Machado «el bueno». 


\section{Bibliografía citada}

AA. VV., La Institución Libre de Enseñanza y Francisco Giner de los Ríos: nuevas perspectivas, 3 vols., Madrid, Fundación Francisco Giner de los Ríos / Institución Libre de Enseñanza / ACE / Residencia de Estudiantes, 2012-2013.

[AzCÁrate, G. de], Minuta de un testamento, publicada y anotada por W..., Madrid, Impr. J. M. Pérez, 1876.

Blecua, J. M. (ed.), Poesía de la Edad de Oro. II: Barroco, Madrid, Castalia, 1987.

Castillo, H. (ed.), Estudios críticos sobre el Modernismo, Madrid, Gredos, 1968.

FESTUGIÈRE, A. J., L'histoire générale des religions. Grece-Rome, Paris, Quillet, 1944.

GINER DE LOS Ríos, F., Estudios filosóficos y religiosos [Obras completas, VI], Madrid, La Lectura, 1922.

GuY, A., Historia de la filosofía española, Barcelona, Anthropos, 1985.

JimÉnEZ-Landi, A., La Institución Libre de Enseñanza, Madrid, Taurus, 1973.

KRAUSE, C. Cr. [sic], Ideal de la humanidad para la vida, con introducción y comentarios por D. Julián Sanz del Río, Madrid, Impr. Manuel Galiano, 1860.

LÓPEZ-Morillas, J., El krausismo español, Madrid, FCE, 1980.

Machado, A., Poesía y prosa, 4 vols., ed. O. Macrì, Madrid, Espasa-Calpe / Fundación Antonio Machado, 1988-1989.

MenÉndez Pelayo, M., Historia de los heterodoxos españoles, II, Madrid, BAC, 1956.

Molinos, M. de, Guía espiritual, ed. J. Á. Valente, Madrid, Alianza, 1990.

PosadA, A., Breve historia del krausismo español, Oviedo, Universidad de Oviedo, 1981.

RodríGuez DE LECEA, T., «La filosofía de la religión del krausismo español», en AA. VV., Reivindicación de Krause, Madrid, Instituto Fe y Secularidad / Fundación Fritz Ebert, 1982.

Rousseau, J. J., Emilio, o de la educación, ed. y trad. M. Armiño, Madrid, Alianza, 1990.

Urales, F. [pseud. de Juan Montseny], La evolución de la filosofía en España, Barcelona, Laia, 1977. 



\title{
FRANCISCO GINER DE LOS RÍOS O EL ARTE DE FORJAR ALMAS
}

\author{
José Luis GonZÁlez Geraldo \& Benito del Rincón IgEA \\ Universidad de Castilla-La Mancha
}

\section{Resumen}

Este trabajo tiene por objeto dibujar el perfil educador de Francisco Giner de los Ríos, el hombre más carismático de la Institución Libre de Enseñanza. Apoyándonos sobre todo en el testimonio escrito de algunos de sus discípulos más cualificados, estas páginas reflejan la actividad de un maestro universitario a pie de obra. Giner superó el horizonte de su época porque se opuso al memorismo estéril y construía el saber con sus discípulos, planteando problemas e invitando a encontrar soluciones. Era, en definitiva, un educador moderno, de corte europeo. Y lo era allá donde estuviera; por eso, con su buen hacer pero, sobre todo, con su ser, iluminó una herencia pedagógica de cuatro décadas, ya en el siglo XX. Que a los educadores de hoy, bien entrado el XXI, nos sirva para reforzar nuestra responsabilidad y redoblar esfuerzos en la tarea, seguramente, más comprometida que existe.

Palabras clave: Francisco Giner de los Ríos; Institución Libre de Enseñanza; ILE; educación; krausismo.

\begin{abstract}
The aim of these lines is to present the portrait of the most charismatic educator of the Institución Libre de Enseñanza: Francisco Giner de los Ríos. Building our discourse on the written testimony of some of his most qualified disciples, these pages show the activity of a university teacher - not just a professor-. Giner exceeded the horizon of his time because he opposed the sterile memorization and built knowledge with his disciples, not only proposing problems but also inviting them to solve them. In short, he was a modern educator who was aware of the European way of teaching. And he was all these things regardless of the place where he was. Therefore, with his savoir faire, but above all thanks to his great way of being, he lit a pedagogical legacy of four decades within the twentieth century. His life may be a good mirror in which educators could see their duties and efforts reflected.
\end{abstract}

Keywords: Giner de los Ríos; Institución Libre de Enseñanza; ILE; education; krausism.

Anales, 27 (2015), pp. 179-200

DOI: 10.14198/ALEUA.2015.27.10 


\section{Introducción}

Se piensa comúnmente de él que consagró toda su vida a la educación. Y es verdad. Más verdad de lo que comúnmente se piensa.

L. ZULUETA

Pocas semanas después de la muerte de Francisco Giner de los Ríos, el 18 de febrero de 1915, el historiador Rafael Altamira publicó un libro homenaje con un sugerente y significativo título: Giner de los Ríos. Educador. La elección del calificativo no fue baladí. Él mismo profundiza en sus páginas para justificar esta elección:

He procurado evitar la palabra «pedagogo» al hablar de Giner. No es que la crea impropia tratándose de lo que él fue principalmente, sino que se ha abusado tanto de ella entre nosotros y se la ha aplicado a tantas cosas solo en la apariencia equivalentes, que he temido un equívoco. Si llamamos «pedagogo» al que sabe de Pedagogía (es decir, doctrina de los demás, y aun al que la elabora propia), es lícito que reservemos la palabra «educador» para quien, independientemente de lo que sepa e invente de esa disciplina, eduque. Puede un hombre poseer toda la ciencia pedagógica posible y ser, por las condiciones fundamentales de su espíritu, incapaz de educar. Todas las recetas juntas de todos los pedagogos, no conseguirán que sea «maestro» un sabio de alma zafia, egoísta, falta de dulzura y ductilidad (Altamira, 1915b: 72-73).

De esta forma quiso recordar Altamira al que fue cabeza visible de uno de los movimientos de ruptura y cambio pedagógico de mayor éxito y calado en nuestro país: la Institución Libre de Enseñanza (ILE). La huella de Giner no solo quedó grabada en las páginas de su legado bibliográfico, sino también, y quizá sobre todo, en los corazones de aquellos que tuvieron la suerte de comprobar el entusiasmo, la sencillez y la amplitud de espíritu del maestro de maestros, apóstol de la enseñanza, pescador de hombres, santo laico, conductor de almas, san Francisco Giner, don Paco Giner, el abuelito o, simplemente, don Francisco. De hecho, todavía hoy sigue vigente el debate que él, quizá por primera vez en España (García Velasco, 2011), entabló entre una labor pedagógica educativa y otra meramente instructiva.

Cien años han pasado desde que nos abandonó y es deseable, pero también necesario, rendir justo homenaje a su figura tal y como en su momento se hizo en el cincuentenario de su querida ILE (Giner de los Ríos, 1926), en el cincuentenario de su muerte (Giner de los Ríos, 1965) 
y, de nuevo, en el centenario de la primera (Programa de la Institución Libre de Enseñanza, 1976). Con este objetivo en mente, estas líneas profundizarán en su obra desde una perspectiva que normalmente suele escapar a los trabajos que tienen en consideración sus libros, ensayos, artículos y demás escritos que resaltan el compromiso pedagógico y la talla intelectual de Francisco Giner de los Ríos. Los textos de Giner son dignos de estudio, pero no obstante «con ser estimabilísimos [...], no darán a la posteridad idea cabal del inmenso valor de este hombre, superior a sus obras escritas» («Estudiante y maestro», 1915: 1). Cossío, discípulo predilecto de Giner, solía excusarse cuando alguno de sus estudiantes le pedía que escribiera algo sobre lo que acababa de enseñarles, pues no veía necesidad en repetir lo que había sido vivido, algo que sin duda aprendió de don Francisco, pues «[e]s manifiesto el desdén de estos hombres por trasladar a obras acabadas su inquietud docente. Se esforzaban sobre todo en ofrecer ellos mismos un modelo de vida; ellos mismos "se escribían" en el comportamiento de sus alumnos» (Molero, 2000: 78).

Cuando alguien pregunta a un profesor a qué se dedica, este rápidamente suele acotar el rango de su influencia a la asignatura impartida. Así, solemos encontrarnos con profesores de historia, de música, de física, etc. Pocos caemos en lo obvio: ante todo somos profesores de seres humanos. El arte de hacer hombres, haciendo patente lo que en ellos es latente (López-Morillas, 1989), forjando personas y no solo profesionales, era sin duda la obra lenta, pero segura, que quisieron Giner y sus colaboradores. De ahí que el calificativo de pedagogo, pese a ser pertinente, le quede pequeño al compararlo con el de educador.

Por estos motivos, consideramos necesario realizar un viaje al epicentro de su día a día, penetrando en aquellas clases donde la relación entre maestro y discípulo era total (Molero, 1987), convirtiendo la enseñanza en un desdibujado ente abstracto difícil de encajar en las premisas de nuestro siglo. Un siglo demasiado preocupado por la posada y no tanto por el camino - por los resultados y no tanto por los procesos-, pero donde todavía puede encontrar su reflejo, más o menos borroso pero igualmente pertinente y deseable (González Geraldo, 2011).

Para conseguirlo hemos acudido al recuerdo de las personas que de él recibieron influencia, bien fuera en relación con su cátedra o en la ILE, y que días, meses e incluso años más tarde, plasmaron por escrito sus vivencias para honrar su memoria y agradecer la educación recibida. Por tanto, no es la voz de Giner la que paladearemos, sino la de sus discípulos; no acudiremos a la semilla, sino a los frutos. Este tipo de escritos solían 
producirse con más frecuencia de la que quizá creamos, sobre todo desde febrero de 1915 y casi siempre en el aniversario de su muerte. Muchos de estos artículos y recuerdos fueron compilados en la sección In Memoriam del BILE ${ }^{1}$. En el fondo «Giner» de la Real Academia de la Historia (34-680/41-763/41-770) están custodiados muchos de los recortes de periódico, e incluso algunos manuscritos originales, de los elogios que posteriormente serían publicados en el BILE. La naturaleza de los artículos recogidos en esta sección del boletín no es solo numerosa sino también ecléctica; por ello hemos priorizado aquellos que no solo exponen aspectos que son de utilidad a la hora de reconstruir la docencia de don Francisco, sino también aquellos que fueron narrados en primera persona, como si de una confesión al diario personal se tratara, admitiendo con ello el beneplácito del giro hacia el individuo que deriva de una concepción posmoderna de la investigación historiográfica, en nuestro caso, educativa. No es casualidad, por tanto, que al igual que en la obra que se publicó en el cincuentenario de su muerte (Giner de los Ríos, 1965), muchas de las referencias utilizadas procedan del BILE.

Este trabajo está estructurado en cuatro partes: su vida, su institución, su cátedra y su huella. Nos ayudará a evocar el momento de aquellas clases y también los sentimientos que en ellas se fraguaron, así como el cúmulo de circunstancias que hicieron de don Francisco una fuente inagotable de influencia educativa.

\section{Su vida}

Como ocurre con muchos de los mejores españoles, la personalidad de D. Francisco ha sido muy superior a su obra escrita. La posteridad no podrá comprender el influjo decisivo ejercido por el maestro sobre sus contemporáneos.

A. REYES

En la vida de Giner podemos diferenciar tres momentos: su etapa como estudiante, sus primeros años como catedrático y finalmente su cenit como fundador de la ILE (Molero, 2000: 34). Seguiremos los dos primeros puntos para conocer, breve pero necesariamente, a la persona que dio lugar al educador y establecer las bases que nos permitirán bosquejar los

1. En 1929 dejan de publicar la sección In Memoriam. Vuelve a aparecer, de manera esporádica, a partir de marzo de 1930 hasta finales de 1936. Hay que resaltar cómo la muerte de Cossío en 1935, entre otros, recoge el testigo de recuerdos que hasta entonces había ocupado, principalmente, la figura de Giner. 
fundamentos de la ILE, institución sin la cual sería imposible entender el calado de la obra de Giner.

Francisco Giner de los Ríos fue el mayor de seis hermanos. Nació en una casa de tres plantas en la ciudad Ronda el 10 de octubre de 1839, teniendo la fortuna de ser criado por una madre inquieta, inteligente y con una cultura que sobrepasaba lo que, para su época, podría esperarse. Su padre fue funcionario de Hacienda, posibilitando una vida acomodada, pero también sujeta a traslados frecuentes, que hicieron que sus años de estudiante discurrieran en distintas ciudades: enseñanza primaria en Cádiz y bachillerato en Alicante.

Giner gozó de una «expresión inteligente y delicada, con gran viveza en el mirar, un rasgo que le caracterizó siempre» (Jiménez-Landi, 1996a: 84), tal y como puede comprobarse en cada retrato y fotografía, donde unos ojos oscuros, casi siempre en una ladeada cara con claras reminiscencias árabes, nos invitan a creer en la serenidad estoica y la pasión ardiente, romántica y aristocrática que le caracterizaba (Castillejo, 1937). Tanto su familia como sus maestros pronto se rendirían ante la sagacidad del joven Giner. Tal y como apuntó su abuelo, «[e]ste niño me admira por sus preguntas y por sus respuestas. O mucho me equivoco, o dará que hablar» (en Jiménez-Landi, 1996a: 83).

En Barcelona se inicia en el derecho y la filosofía de la mano de F. Javier Llorens y Barba, de quien aprendió el amor por la profesión docente más que las doctrinas recibidas. Terminará sus estudios universitarios en Granada, licenciándose en 1859 tras haber conectado con la filosofía alemana (Kant, Hegel, Ahrens y Krause, principalmente) gracias a don Francisco Fernández y González, único profesor cuya cátedra salvaba del sentimiento de pérdida de tiempo que le quedó de sus años de estudiante en la ciudad andaluza. Quizá fueran esa inquietud y desasosiego los que le impulsaron a cultivar no solo sus estudios intelectuales sino también las artes, perfeccionando sus conocimientos musicales o su vocación hacia la pintura, llegando a tocar varios instrumentos - Mozart era su favoritoy a realizar varios retratos y escenas entre los que podemos destacar una cabeza de San Pablo o las ruinas de un templo griego que presidió durante muchos años el comedor de la ILE (Jiménez-Landi, 1996a: 85).

Entre las amistades forjadas durante estos años es inevitable resaltar la que estableció con Nicolás Salmerón, pues el destino imbricó sus nombres en las costuras de la historia en más de una ocasión. Tras su llegada a Madrid, en 1863, entabla amistad, entre otros, con el insigne Julián Sanz del Río, verdadero texto vivo para entender la evolución del pensamiento 
gineriano al amparo del krausismo. Allí trabajó como agregado diplomático y, al mismo tiempo, cursó el doctorado. Siempre le quedó tiempo para visitar el Ateneo, así como otros círculos culturales parecidos a los que ya frecuentaba en Granada y que le sirvieron para relacionarse con personalidades como, por ejemplo, Benito Pérez Galdós. En 1867, dos años después de alcanzar el grado de doctor en Derecho Civil y Canónico, y gracias a las influencias de su tío Antonio Ríos Rosas, que impidió el veto que hacia Giner se tenía por sus pensamientos krausistas, finalmente obtiene la cátedra de Filosofía del Derecho y Derecho Internacional de la Universidad Central. Ante él se abre un mundo de posibilidades que no tardará en volatilizarse cuando Julián Sanz del Río, Fernando de Castro y Nicolás Salmerón son apartados de sus cátedras por no aceptar las rígidas propuestas que el ministro Orovio trataba de imponer en cuestiones políticas y religiosas. Estamos ante el suceso conocido como la Primera Cuestión Universitaria. Giner protesta ante las destituciones de sus compañeros y amigos, sufriendo un destino similar.

Tras la revolución de 1868, los perjudicados no solo recuperan sus cargos sino también mayor poder para reformar la universidad que los desterró de sus cátedras. No obstante, el efímero Sexenio Revolucionario no fue suficiente para conseguirlo. Si la Septembrina repuso a los catedráticos, la Restauración borbónica devolvió el ministerio a Orovio, quien a través del Real Decreto de 26 de febrero de 1875 puso sobre la mesa, por segunda vez, la cuestión universitaria. Estado e Iglesia se enfrentaban de nuevo a la academia. Giner, entre otros, se negó a ceder el terreno conseguido y acatar nuevas normativas que seguían tratando de recortar la libertad y autonomía universitaria. La reacción por parte del Gobierno no se limitó a la separación de la cátedra, sino que recurrió también al destierro y a la prisión.

De esta forma volvería don Francisco a Cádiz: enfermo y afligido para ser encarcelado en el castillo de Santa Catalina, prisión militar. Allí se encargará de meditar y elaborar las bases de la ILE con el objetivo de fundar una universidad libre, completamente alejada de la que en esos momentos les repudiaba. En 1881 será repuesto en su cátedra y, simultaneando esfuerzos, continuará con su sueño de ver un nuevo florecer en España usando para ello la herramienta educativa. Alérgico a la vida pública que la política podía ofrecerle, «[n]o quiso ser subsecretario, ni ministro, ni siquiera caballero gran cruz de Alfonso XII, Orden creada para él. Fue Maestro — con M mayúscula—, maestro del pensar, el sentir y el querer» (Zozaya, 1915: 64). 
Sin entrar en más detalles sobre su vida, pues no es el objetivo de estas páginas, es ciertamente irónico pensar que una persona que se dedicó por completo a nutrir el espíritu de todos los que le rodeaban terminara muriendo, según su discípulo Cossío, de una gran desnutrición (JiménezLandi, 1996c). Evocando a su madre con su último aliento, don Francisco nos abandonó a primera hora del 18 de febrero de 1915, casi el mismo día que su respetado Pestalozzi. Al día siguiente, en su funeral, Giner ofreció su última lección: «quería enseñarnos a ser humildes y a ser inquebrantables enfrente de la muerte. Por ello prohibió, en la exposición y enterramiento de su cuerpo, toda pompa, todo ritualismo, todo aparato fúnebre que afeara o ridiculizara el trance augusto del no ser» (Dicenta, 1915: 43).

\section{Su institución}

D. Francisco Giner no tuvo hijos; no creó un hogar; es decir, lo creó, y muy grande. ¿Qué otra cosa que una inmensa familia era su Institución, alma de su alma, obra total suya, de aquel su enorme espiritu educador genial?

A. DE SEGOVIA

Admitimos que es ciertamente pretencioso encabezar este apartado con un posesivo que el mismo Giner rechazaría, pues no estuvo solo en esta empresa y, además, nunca quiso aparecer al frente, forzando con ello la elección de otra persona para el puesto que, por méritos, debía recaer en él (Castillejo, 1937). Incluso existen dudas sobre si la idea original fue suya, de Salmerón o quizá de ambos (Jiménez-Landi, 1996a: 334), pero lo cierto es que el «alma» de la Institución no fue otra que la de don Francisco:

En aquel grupo famoso de los discípulos de Sanz del Río, entre aquellos hombres animados todos del más sincero entusiasmo por la ciencia y la virtud, Azcárate, Calderón, Costa, Messía, Tapia, Salmerón, Soler, Quiroga, Caso, Linares, Cossío, Posada y tantos otros, fué [sic] D. Francisco siempre el fuego que encendía los corazones y el lazo que los conservaba unidos (García Morente \& De los Ríos, 1918: 60).

La historia no admite debate: «Francisco Giner de los Ríos y la Institución Libre de Enseñanza, o la Institución Libre de Enseñanza y Francisco Giner de los Ríos: dos nombres que aparecen siempre juntos y cuya separación es imposible» (Jiménez García, 1987: 131). Por ello creemos necesario hablar de su institución.

Así, convencidos de que para conseguir una nueva sociedad era preciso forjar un nuevo ideal de hombre, las bases y estatutos de la ILE son 
firmados el 10 de marzo de 1876. El 29 de octubre de ese mismo año, a las dos de la tarde, el presidente de la incipiente ILE, Laureano Figuerola, leía el discurso que abría el primer curso académico. El objetivo era fundar una universidad libre, a imagen de la que existía en Bruselas, pero pronto, gracias principalmente a los consejos de Azcárate y Figuerola (Jiménez-Landi, 1996a: 334), consiguieron el éxito centrándose en la segunda enseñanza, incluida desde sus comienzos, pero también con la enseñanza primaria. Del sueño de construir una educación superior de calidad, pasaron a alcanzar una calidad superior en los niveles educativos previos, entendidos de manera unificada. El interés que suscitó la iniciativa era tal que, viendo los nombres de sus valedores y accionistas, puede decirse que prácticamente «representaban a la España liberal en todas las esferas» (ibid.: 382).

Entre sus estatutos cabe destacar el artículo quince. El mismo que don Laureano Figuerola resaltó en el discurso de inauguración del primer curso académico y que el propio Giner usó en un breve escrito publicado póstumamente para conmemorar el cincuentenario de su obra:

La Institución Libre de Enseñanza es completamente ajena a todo espíritu o interés de comunión religiosa, escuela filosófica o partido político, proclamando tan solo el principio de la libertad e inviolabilidad de la ciencia y de la consiguiente independencia de su indagación y exposición respecto de cualquiera otra autoridad que la de la propia conciencia del profesor, único responsable de sus doctrinas (Giner, 1926: 20).

En este escenario, y rehusando siempre acudir al apoyo estatal para mantener la libertad a la que aspiraban, encontramos una institución educativa de paz, libertad de pensamiento, nuevas ideas y respeto mutuo (Castillejo, 1937). No había exámenes, ni libros de texto, y cada estudiante construía intuitivamente su propio material. Siempre que era posible, acudían a la fuente real de la enseñanza y no a su representación. La coeducación allí implantada era completamente novedosa y motivadora. Nada que ver, en definitiva, con los postulados memorísticos y librescos que solían atestar las aulas. Todavía hoy, algunos de estas propuestas serían novedad en nuestras aulas. Al concretar sus fuentes pedagógicas y su propia producción escrita, puede apreciarse que Rousseau, Pestalozzi y Froebel influyeron abiertamente en su obra (Molero, 2000: 76).

Alejado del estereotipo que todavía hoy se tiene hacia el maestro como persona de dudosa capacidad, la excelencia del profesorado fue un factor imprescindible para entender el éxito de Giner y sus correligionarios (Molero, 1987). El papel activo del alumno era esencial, pero siempre 
acompañado de maestros bien preparados. La figura del educador — diríamos hoy- es la principal variable del proceso educativo.

Paralelamente, recogiendo las ideas krausistas, la educación del cuerpo debía acompañar necesariamente a la instrucción de la mente, por lo que las excursiones y deportes eran comunes dentro de la ILE. La renovación pedagógica del siglo XX en España recogería con fuerza este testigo. Defendiendo una educación integral, a la par que neutra, tampoco se olvidaba el cultivo de las cualidades más humanas: «La inteligencia, por sí misma, da luz, no calor» repetía Giner a sus discípulos (1922: 132). Para los institucionistas la instrucción solo tiene razón de ser en cuanto puede cooperar a formar hombres en sentido universal, educador e íntimo (Giner, 1926: 25), buscando una realización total del ser humano que atienda y dé respuesta a la completa estructura que nos conforma. La educación integral que hoy jalona casi la totalidad de las leyes educativas era para - y en-Giner una realidad.

En un momento en que los maestros sufrían la desconsideración y el desprecio propios de un pueblo analfabeto, las conexiones de la ILE con las más punteras innovaciones pedagógicas del momento eran más que patentes. De esta forma, España estuvo abierta a las influencias extranjeras, extranjerizantes para un cierto sector que observaba estas conexiones con recelo (Martín-Sánchez Juliá et al., 1940). Entre otras, hay que destacar las influencias anglosajona, alemana, belga y francesa (Otero, 1994) y, con todo lo dicho, entenderíamos la simiente de históricos organismos y actividades que explican en gran medida la vida cultural de las primeras décadas del siglo pasado: Museo Pedagógico Nacional, Colonias Escolares, Misiones Pedagógicas, Junta para Ampliación de Estudios (JAE), Residencia de Estudiantes o Instituto-Escuela, por señalar los más relevantes. Intereses espurios aparte, nadie podrá nunca negar el éxito de la ILE como escuela, convento y hogar (Pijoán, 1927a). Todo ello nos lleva a preguntarnos: ¿cómo eran las clases de este austero y sobrio maestro?, ¿por qué es tan profunda la huella que Giner dejó en sus discípulos y compañeros?

Su cátedra

Su clase en la Universidad era la prolongación de sus amistades y familia. Ninguno de cuantos la visitaron podrá olvidar aquellos ratos en que sacudian el espiritu de penosas rutinas...

L. LÁZARO Y JUNQUERA

Al hablar de sus clases no nos referimos, fundamentalmente, a la metodología o al programa que llevaba a cabo, sino a la actitud que en ellas 
mostraba y al sentimiento que en ellas irradiaba. No queremos recoger vestigios de sus enseñanzas, sino de su educación. Antonio Zozaya recordó así su primer encuentro con «el gran Giner»:

Llegó hasta nosotros, nos saludó como a personas de su más alta estimación, nos tendió sus manos finas y nerviosas, calzadas de guantes amarillos, y nos invitó cortésmente a acompañarle al interior de la cátedra. No hay que decir que lo hicimos de muy buen grado y encantados de tan simpática acogida. Amigos míos —nos dijo, después de sentarse entre nosotros, como un camarada-, deseo hacerme merecedor del afecto de ustedes, y mi mayor pesar será no colaborar dignamente en la obra de cultura que «todos» juntos hemos de emprender. Yo no paso lista ni examino; así, la asistencia a mi clase es absolutamente voluntaria. Siento no ofrecer a ustedes mi libro de texto, porque no lo tengo, y lo dejo a elección de cada cual; en cuanto al programa, lo he impreso y suplico a ustedes que tengan la bondad de aceptarlo. Admitimos el ejemplar y no pudimos menos de pensar en la diferencia entre nuestro nuevo catedrático y otros que habían convertido la enseñanza en materia de explotación. Y comenzó un diálogo espontáneo, admirable, verdaderamente pedagógico. Comprendimos que estábamos en un universo nuevo [...] hasta entonces habíamos sido alumnos estudiosos; a partir de aquel día, comenzamos, en verdad, a ser hombres (Zozaya, 1915: 64).

Desde su cátedra, dentro del clima de complicidad arriba sugerido, Giner nunca desdeñó una idea de sus alumnos por absurda que fuera, estimulando a sus estudiantes a pensar y reflexionar a través del método socrático, despertando interés por la ciencia, respeto a la verdad y amor por la humanidad. El proselitismo no tenía cabida en sus lecciones, aceptando siempre la ideología e idiosincrasia de sus estudiantes.

La Filosofía del Derecho, materia que impartía, no era sino la excusa perfecta para ayudar a sus alumnos a crecer y madurar. Solía repetir la máxima de Kant: «Yo no enseño Filosofía, sino a filosofar [...] No enseñaba, pues, la ciencia, sino a pensar, y no pareciéndole aún bastante el saber pensar bien, hacía más: enseñaba a vivir» (García Morente \& De los Ríos, 1918: 62). Por este motivo no se preocupaba «de que sus discípulos conocieran una construcción filosófica o una teoría jurídica más, sino de que en el progresivo desenvolvimiento de su espíritu llegasen a un estudio más elevado y perfecto» (Ureña, 1915: 317).

Al no ser obligatorias para la obtención del grado, sus clases no solían estar abarrotadas; ni siquiera iban a diario todos los matriculados. Pese a ser un gran orador, Giner se cuidaba mucho de no hacer oratoria, cortando secamente sus palabras cuando el entusiasmo le llevaba a 
pronunciar un improvisado discurso para volver al tono familiar de la conversación, sencilla pero persuasiva, que le permitía charlar con la lengua y con el corazón. Cuando don Francisco se dejaba llevar por la situación, abandonándose a sí mismo hacia las cimas de la elocuencia, solía romper

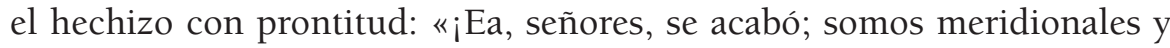
sensibleros, somos incorregibles!» (Palacios, 1926: 63); o "Cuidado, que estoy haciendo retórica» (Horrillo, 1931: 316). Incluso aquellos que no se sentían motivados por el contenido de sus clases reconocían la capacidad que tenía para atraer y remover el pensamiento de quienes lo escuchaban (Ballester-Soto, 1916). Unos estudian, otros escriben, pero su tragedia y función, como el mismo Giner reconoció, fue tener que hablar siempre con todo el mundo (Pijoán, 1927a), lo que él llamaba «el santo sacramento de la palabra» (Giner de los Ríos, 1965: 1). No obstante, de aquellas charlas y conversaciones salieron libros de extraordinario mérito (Horrillo, 1931). Así, de la palabra del educador, como semilla, obtuvimos excelentes frutos, algunos de ellos recogidos en las referencias de este artículo.

Además de no pasar lista ni realizar exámenes, raramente se sentaba o hablaba desde la plataforma: «Decía que su clase era como la plaza pública, libre para todo el mundo; pero no había clase de más orden, respeto, cortesía y educación, no impuestos por precepto, sino difundidos por el ejemplo que trascendía de la conducta y de los modos y maneras del profesor insigne y único [...] Y es que Giner, en todo procedía según pensaba» (Juncal, 1915: 72). Incapaz de mentir o de callar la verdad, era el ejemplo su mayor baza pedagógica, enseñando en sus paseos, conversaciones y tertulias de los miércoles tanto o más que en su cátedra o bajo el auspicio de la ILE: «¿Que antes de Giner de los Ríos hubo en España y en todas partes buenos maestros y excelentes profesores? Indudable. Pero Giner de los Ríos, sobre poseer las más altas virtudes, encarnó, personificó y enseñó como nadie la humanización de la enseñanza» («Estudiante y maestro», 1915: 1). Solo un educador con sólidas virtudes humanas es capaz de transmitirlas; la coherencia del educador, el alineamiento entre pensar y vivir son necesarios para educar.

En el antiguo decanato de la Facultad de Filosofía y Letras, un espacio pequeño, agradable y con cierta intimidad, a media tarde, en una suave luz y en discreto silencio, se reunía el maestro con sus discípulos. Las clases solían comenzar con la lectura del diario del curso, realizado y leído por los propios alumnos ante la supervisión y cuestionamiento de don Francisco: «Acostumbrado a ver deshechas, una por una, las afirmaciones que se había permitido hacer, el alumno adquiría pronto una cautela, 
una reserva, una prudencia peculiares, que constituyen uno de los estigmas más aparentes de los discípulos de D. Francisco Giner» (Bernaldo de Quirós, 1915: 187). Tras la lectura, daba comienzo una investigación, cimentada en el método socrático, y no era raro que la sesión terminara con una reflexión en voz alta por parte de Giner conforme moría la luz diurna y alguien, en respetuoso silencio, se levantaba para encender los candelabros que estaban sobre la chimenea que, en las tardes de invierno, revestía el aula de un resplandor tan cálido como el ambiente de enseñanza conseguido por don Francisco. Un recuerdo íntimo y melancólico, casi hogareño, que tiende (tendía) a repetirse:

El aula-laboratorio donde D. Francisco Giner de los Ríos daba su clase en la Universidad Central, en los años que yo la conocí — hace más de 30era como la palma de la mano, muy chiquitita, capaz para siete u ocho personas lo más. A la derecha, entrando, tenía una chimenea, pequeña también, que el bedel, Joaquín, un buen hombre, encendía los meses de invierno. De espaldas a esta chimenea, de pie, siempre de pie, cuántas veces, sin darse quizá cuenta, ha sido elocuentísimo, removedor, profundo. Era su sitio predilecto; de visión inolvidable (Horrillo, 1931: 315).

Amante de las cosas sencillas y desdeñoso de las superficiales e inertes, don Francisco pronto distinguía entre los estudiantes preocupados por el aprendizaje y los alumnos deseosos del éxito académico:

Cuando veía aparecer, en sus clases del Doctorado —él tenía una pupila de lince para conocer a las gentes- a esos estudiantones hueros que van a las aulas sin vocación alguna pero ávidos de obtener a fin de un año un papelito con una nota, para canjearlo más tarde por un diploma en papel vitela, sentía una profunda tristeza, una amargura que rara vez disimulaba. Llegaba hasta rogarles que se marchasen, que tomasen el programa $\mathrm{H}$ o el texto $\mathrm{B}$ para que, a fin de curso, el señor $\mathrm{X}$ los examinase (Machado, 1915: 220).

De esta forma, con la fina ironía cáustica que le caracterizaba, separaba el maestro el grano de la paja, el interés del interesado: «Viene usted con demasiados sobresalientes y demasiados premios — solía decir a los licenciados más sabihondos-; ya veremos si sirve usted para algo...» (Palacios, 1926: 62). Siendo consciente de que sus enseñanzas solo podían interesar realmente a unos pocos, «[a] consejaba con no fingida sinceridad que a la clase no viniesen sino los que tuvieren ese interés verdadero por la cosa. Y así, [... ] resultaba al cabo la clase reducida a un escaso número de verdaderos estudiosos, 8 o 10, entre los que siempre había algunos discípulos de 
años anteriores» (García Morente \& De los Ríos, 1918: 61). Era entonces, habiéndose quedado en intimidad, cuando empezaba realmente la clase. Sobre sus hombros pesaba con fuerza la responsabilidad de forjar seres humanos que construirían una España mejor. Como recuerda otro de sus discípulos, «[e]n un país donde todo está por hacer y es tan enorme el atraso, un hombre de la sensibilidad de D. Francisco no podía limitarse a sentarse en el sillón de profesor y lanzar diariamente una lección sin preocuparse del alumno» (Alas Argüelles, 1915: 254).

No importaba que estuviera dentro o fuera de un aula; Giner era educador allá donde estuviese, viviendo siempre por y para los demás: «y no solo dió [sic] doctrina y ciencia, que no era lo que él más estimaba, sino que dio [sic] vida e ideal y nobleza y ánimo y dignidad y profundo sentido del propio valor de la persona» (García Morente \& De los Ríos, 1918: 60-61). Al terminar las clases por cuestiones de horario, discípulos y maestro bajaban las escaleras juntos, siguiendo la clase oficiosa y ociosamente: «Recuerdo que un día nos dieron las siete en una farola de los bulevares. D. Francisco no tenía prisa cuando estaba comunicando a los jóvenes sus lecturas, sus estudios, sus enseñanzas» (Ballester-Soto, 1916: 287); estos llegaban incluso a seguirle en sus largos paseos a orillas del Manzanares para continuar recibiendo sus enseñanzas ( «La figura de actualidad», 1921). No importaba el lugar ni el momento; don Francisco no acudía a la cátedra, pues la cátedra siempre iba con él:

Y la cátedra no terminaba en la Universidad, ni en la Filosofía, ni - menos- en el Derecho: continuaba a la salida, en la calle, cuando acompañábamos al maestro; y seguía los domingos en el campo, o en la sierra, o en los pueblos aldeanos, embebiéndonos en la Naturaleza; o en los museos y las viejas ciudades castizas, reviviendo el Arte y la Historia, donde él nos descubría realmente a España, a la pasada y a la por venir —ila eterna!-, despertándonos en la verdadera adoración hacia ella... Que ya ni por casualidad se rozaba en la conversación el objeto limitado y concreto de la «clase», difundida y extendida entonces, en la comunión apasionada de las almas, a la vida afectiva y a la moral, y a la personalidad entera (Palacios, 1926: 63).

Todo educador que se precie conoce el valor del leitmotiv semper discentes. No era raro, por tanto, no solo ver compañeros y alumnos que volvían a sus clases por el mero gusto de disfrutar de sus enseñanzas, sino también encontrárselo, codo con codo, compartiendo asiento con otros estudiantes mucho más jóvenes que él. Así lo conoció Ballester-Soto, que vio a un viejecito nervioso entrar un poco tarde en la clase de Salmerón y, 
con extraordinaria atención, apuntar alguna frase o indicación de vez en vez, desapareciendo por la calle Ancha con agilidad tras terminar la clase (Ballester-Soto, 1916). Igualmente solía acudir a las clases de su querido Bartolomé Cossío, en el Museo Pedagógico (Jara, 1921). Incluso en sus propias clases don Francisco no dejaba de ser estudiante; en ellas no había catedrático, solo personas embriagadas por el espíritu investigador hasta conseguir un peculiar laboratorio de humanidad donde todos aprendían (Sánchez, 1918). De esta forma, es lógico comprobar cómo, en sus clases «no hacía lecciones seguidas, ni explicaba un sistema, ni siquiera un asunto monográfico determinado. Confiaba a los alumnos trabajos especiales, estos los producían en notas, sobre las que recaía el más minucioso estudio. El profesor suscitaba problemas, aportaba información, sugería dudas y reservas, provocaba nuevos estudios y confrontaciones, indicaba autores y libros y hablaba de su significación sobre los puntos más importantes (Palacios, 1926: 62).

Giner no era un hombre de masas; se sentía mejor en las distancias cortas y en grupos reducidos. En su cátedra, casi en familia, labró en tierra fértil. No obstante, pese a que sus clases fueron un oasis de educación en el desierto de la instrucción que por entonces predominaba, su mayor éxito extralimitó su cátedra, entendida esta como parte exclusiva del sistema educativo.

\section{Su huella}

¡Qué clase! Pero, ¿esta clase, hay que preguntar, esta clase única en su época, donde de modo tan admirable se enseñaba a trabajar y a pensar, era toda la labor del gran maestro para sus discípulos? Estoy por decir que ni siquiera la mejor; porque la clase, por ser clase, y aun dada por un maestro todo espíritu, saber, vocación, luz, pasión, es una cosa intelectual, y D. Francisco, por imperativo de su propia estructura y por amor a sus discípulos, atendía, para reformarlos, a todos los aspectos y direcciones de la vida, y no solo en la persona de sus discípulos. Por esto, D. Francisco donde era más grande, donde hacía más por las almas, donde más las conquistaba, era en su casita de la Institución, o en el campo, o en la calle.

A. HORRILlO

Sirvan las anteriores palabras para constatar la gran influencia que don Francisco tuvo no solo dentro sino también, y quizá sobre todo, fuera de la universidad. Educar es una profesión eminentemente vocacional; 
un maestro no trabaja enseñando, más bien vive enseñando sin llegar a distinguir con claridad la delgada línea que separa su trabajo del resto de facetas de la vida. Así era Giner, que alcanzaba su máxima expresión como educador cuando no se encontraba enseñando en su cátedra. Será, pues, dentro de los confines de su amada ILE, así como en las numerosas excursiones y conversaciones informales que de ella surgieron, donde realmente encontremos los orígenes de la profunda huella que dejó en los que le conocieron: tanto adultos como niños.

Como hemos comentado anteriormente, la ILE surgió con la intención de llegar a ser una universidad libre, con ciertos tintes ateneístas (JiménezLandi, 1996b), pero pronto cambió de rumbo al conservar la educación secundaria y al poco tiempo instaurar la primaria (1878) e incluso una escuela de párvulos (1885). Este giro no solo tuvo como causa la falta de medios para sostener tamaña empresa, sino también la intuición de que el verdadero cambio que habría de dar una España mejor, para llegar a tener profundas raíces, debía ser sembrado cuanto antes. Giner así lo reconoce al citar a San Anselmo: «Si plantáis un árbol, y lo atáis y apretáis por todas partes, de suerte que no pueda extender sus ramas, ¿qué os encontraréis, cuando lo desatéis, al cabo de muchos años? Un árbol con las ramas torcidas y encogidas» (Giner de los Ríos, 1910: 290). El cambio universitario no solo era difícil de conseguir, sino quizá también demasiado tardío de ser alcanzado. Era preciso influir prontamente en la juventud. Desde este nuevo prisma, y precisamente por haber sido un gran pedagogo, don Francisco nunca fue pedante. La magia que ofrecía a sus estudiantes universitarios no desaparecía al relacionarse con la infancia; las clases que Giner impartía en la ILE, al igual que las de su cátedra, estaban llenas de vida y aprendizaje socrático en estado puro:

Si en el trato con jóvenes y hombres poseía ese tacto, ese delicado sentimiento de adaptación, en el trato con los niños, era admirable el arte con que sabía compenetrarse en seguida con las frágiles y vacilantes emociones de la tierna edad. Nunca fingía la puerilidad; nunca jugaba a niño; nunca hacía ese ademán de condescendencia, como quien se rebaja a tratar con párvulos. [...] iqué sensación tan profunda entre de admiración y ternura hemos sentido al verle y oírle en alguna de sus clases con los niños de la Institución Libre de Enseñanza! Los chicos hablaban, interrumpían, se interrogaban unos a otros y al maestro. Jamás aquello fué [sic] desorden ni algarabía, sino el movimiento natural de un interés que Don Francisco ingenuamente despertaba a cada cosa que decía. En apariencia, allí se charlaba; en realidad, se pensaba, y a los pocos minutos de oir [sic] aquella clase, veíase cómo las cuestiones iban de suyo 
suscitándose unas a otras en la discusión ordenada de los infantiles ingenios. D. Francisco, de vez en cuando, con una observación, con una objeción situada en el plano mismo en que se movía el discurso, reponía las cosas en su punto o alzaba como por encanto un tramo más el nivel de la conversación. Hemos oído a chicos de 12 años discurrir sobre Metafísica con ingenua, sí, pero certera agudeza. Hemos visto a Don Francisco enseñar historia de las religiones en unas clases en donde el que menos hablaba era el maestro mismo (García Morente \& De los Ríos, 1918: 62).

Con todo, observamos cómo en los jardines y aulas de la Institución Giner fue un excelente guía de la juventud (Mesa, 1920). Allí, junto a aquellos espíritus vírgenes, don Francisco se convertía en el abuelito, normalmente rodeado de racimos de chiquillos, entre los árboles del jardín (Pijoán, 1927a). El recuerdo que dejó en los corazones de los niños es entrañable:

Los párvulos aguardábamos, jugando en el jardín de la Institución, al maestro querido. Cuando aparecía D. Francisco, corríamos a él con infantil algazara y lo llevábamos en volandas hasta la puerta de la clase [...] En su clase de párvulos, como en su cátedra universitaria, D. Francisco se sentaba siempre entre sus alumnos y trabajaba con ellos familiar y amorosamente [...] Toda la España viva, joven y fecunda acabó por agruparse en torno al imán invisible de aquel alma tan fuerte y tan pura (Machado, 1915: 220).

En realidad, entendía Giner que debía haber continuidad entre las tres etapas del sistema educativo: «La universidad tendría, [...] a la vez que carácter profesional, carácter general, constituyendo en este último respecto un nuevo grado del mismo tipo que la escuela primaria y la secundaria, y en continuidad indivisa con esta» (Giner, s/f).

No es por tanto de extrañar que, gracias a su cercanía y carisma, bien desde la cátedra o desde la ILE, se llegara a afirmar que fue el hombre del momento que más influyó en España, dando muchos de los profesores y políticos, entre otros profesionales, más eminentes que ha visto nuestro país. Y que incluso tuvo — quizá con cierta exageración pero significativamente comparado- «más influencia social en ciertos aspectos que todas las órdenes religiosas juntas» (Juncal, 1915: 72). La profundidad de la huella que dejó es de tal magnitud que quedó escrito:

Si algún día España llega a ser grande en el mejor sentido de la palabra y los pueblos civilizados del planeta vuelven hacia nosotros su mirada, acaso haya historiadores superficiales que escriban cuatro palabras sobre el maestro, sin concederle apenas importancia. Pero si algún historiador de espíritu se ocupa entonces de contar los orígenes de nuestro 
engrandecimiento, buscándolo en sus causas remotas, llegará después de seguir mil caminos subterráneos, a colocar en puesto culminante al viejecito modesto, bueno y pulcro que ahora descansa provisionalmente en el cementerio civil entre sus amigos y maestros (Alas Argüelles, 1915: 255).

Cierto día, uno de sus estudiantes se lamentaba de que por no haber salido nunca de España, solo había conocido a don Francisco. Otro de sus discípulos le contestó sin dudarlo: «Ni aunque hubieses visto Universidad por Universidad y Seminario por Seminario de toda Europa, encuentras otro D. Francisco. Profesores eminentes, sí, muchos; pero un maestro, un maestro como D. Francisco, en ninguna parte» (Horrillo, 1931: 316). Altamira, en este sentido, afirmó que había que remontarse a Jovellanos para encontrar semejanzas morales e intelectuales suficientemente elevadas como para asemejarlas a las de don Francisco (1915a: 59).

Sabio, generoso, bueno, recto, amable, inteligente, dulce, tolerante, finamente irónico, austero, sencillo, afable, modesto, curioso, sociable, gracioso, enérgico, virtuoso, elocuente, seductor, poético, inolvidable... Los adjetivos que resaltan los porqués de su magnética personalidad educadora son tan numerosos como múltiples son los discípulos que le honraron con sus recuerdos. Según parece, uno de los últimos libros que don Francisco tuvo el placer de disfrutar fue Platero y yo. Una obra íntima, tierna, sencilla, exquisita y única, según un escrito de Giner al autor (Jiménez-Landi, 1996c: 84). Por su parte, así lo recordó Juan Ramón Jiménez:

Iba y venía, como un fuego con viento; y se erguía, silbante víbora de luz; y se derramaba y se prendía, chispeante enredadera de ascuas; y se abalanzaba, leonzuelo relampagueante; y se encauzaba, reguero puro de oro; y aparecía, sin unión visible, aquí y allá, por todas partes, delgado, aéreo, inasequible, con la elasticidad libre de la diabólica llama [...] Sí, una alegre llama condenada a la tierra [...] más que nada, luz, graciosa luz, luz (Jiménez, 1924: 224).

Luminosidad que, lejos de apagarse, quedó albergada en el alma de sus discípulos. Se atribuye a Horace Mann la autoría de esta sentencia: «El maestro que intenta enseñar sin inspirar en el alumno el deseo de aprender está tratando de forjar un hierro frío»; nada que ver con la luz que Giner irradiaba, siempre llevada a la realidad de los actos. La influencia de un maestro convierte la docencia en un ejercicio tan duradero como profundas y sentidas sean sus enseñanzas. No es una locura pensar que don Francisco, a través de estos cien años, de corazón en corazón y mientras sea recordado, sigue de algún modo entre nosotros. 


\section{Conclusiones}

Don Francisco Giner ha constituido un caso excepcional en la historia de la España contemporánea. Pudo serlo todo, llegar a todo, alcanzar las más útiles posiciones, las más ventajosas prebendas, y renunció, no solo a lo honorífico, sino a lo positivo y práctico. No necesitaba nada, porque su exclusivo anhelo era hacer aquella fecunda siembra de ideas y de estímulos, y lo que vale más aún, de amor y de cordialidad.

E. MESA

En el centenario de su muerte, el recuerdo de Francisco Giner de los Ríos evoca la imagen de un maestro generoso, amable y cercano, capaz de infundir respeto (auctoritas) sin necesidad de imponerlo (potestas), encendiendo el amor, avivando el entusiasmo y moderando la pasión (García Morente \& De los Ríos, 1918).

La coherencia entre sus ideales y acciones le granjeó el reconocimiento de los que en él vieron fuente de luz, constancia y bondad. Para él, como para cualquier moralista, lo esencial era la conducta y no solo la luz que otorga el saber (Altamira, 1915a: 60). Fue maestro dentro y fuera del aula, respetando al alumno bajo un principio de humanidad sabiamente atemperado que le hizo sobrepasar las categorías establecidas hasta llegar a la más alta cota educativa: «Más aún que pensador y jurista, fué [sic] Don Francisco Giner educador, foco ardiente de vida y doctrina, cuyos rayos penetraban hasta en lo más íntimo de quienes se movían en torno suyo. Nadie de los que le conocieron y trataron escapó a su poderoso influjo» (García Morente \& De los Ríos, 1918: 60).

Observando sus hábitos, es inevitable preguntarse cuántos profesores de universidad, hoy en día, suelen acudir a las clases de sus compañeros para escucharles, tomar notas y aprender de ellos. Sin duda habrá quien considere que el avance de las TIC hace innecesario acudir físicamente al aula del compañero, perdiendo con estas erróneas justificaciones el aspecto humano que debería prevalecer en toda educación superior. Mientras que los libros y artículos que llegan a nosotros están cargados de saber, la sabiduría es más difícil de plasmar en papel. Esencia que otro grande de nuestro campo, Ortega y Gasset, supo apreciar al acuñar su «Pedagogía de la contaminación» (1982), recordándonos que solo a través del contacto físico podremos superar la visión mecánica de la enseñanza. ¿Dónde quedó la humanidad que hacía de la universidad un conjunto, una pluralidad, pero no solo de saberes sino de personas? (Giner de los Ríos, 1910: 
306). ¿No sería preciso, pues, dirigir nuestros pasos hacia una universidad más humana? (González Geraldo, 2014).

Antítesis de dómine, sus estudiantes paladeaban cada momento sin importar la hora de finalización de las clases. Niños y no tan niños, todos por igual como igual era la dedicación y compromiso que a todos profesaba. Actualmente, la motivación del alumnado sigue siendo una de las preocupaciones que los docentes no acaban de resolver; con frecuencia, los estudiantes están más pendientes del reloj que de las lecciones, huyendo en tropel al segundo siguiente de la hora límite. El amor incondicional que hacia ellos tenía Giner residía en el deseo de convertirlos en seres humanos «aptos para la lucha científica y social, que pudieran, con el natural desarrollo e incontrastable empuje de una rica y exuberante actividad, dar días de gloria para la patria [...] ¡Quién podrá sustituir a tan inolvidable maestro!» (Ureña, 1915: 317).

Sin duda, como ya hemos apreciado, Giner pudo tenerlo todo, pero prefirió labrar en la árida pero hermosa tierra de la juventud española, renunciando a su gloria personal en favor de la colectiva (Reyes, 1925). No hay mayor sacrificio para quien desee considerarse educador. Era un caso de abnegación viviente; no ambicionaba fortuna ni gloria, dinero ni vanidad. Quería solo ser útil a la humanidad, derrochando lo único que poseía: el tesoro inagotable de su ciencia (Ballester-Soto, 1916). Era amante de la ciencia, la justicia, la libertad y, ante todo, del ser humano. Siempre con gente joven, don Francisco amaba profundamente la juventud y lo que ella significaba como deseo de porvenir:

...mi protector comenzó a hablarme de la Patria, del porvenir de España, de la miseria de los campos, de la misión de sus juventudes — de la altísima misión de las juventudes españolas-, del abandono cultural... [...] El viejecito misterioso tenía una receta, una receta tan misteriosa como él, con la que fabricaba juventud (Martín Granizo, 1916: 159).

Quede en nuestros corazones la obra lenta, pero segura, de don Francisco, que no era otra que la siembra de humanidad, pues nada de lo humano le era ajeno (Pijoán, 1927b). Desde allí, en lo más hondo de nuestra vocación por la docencia, «entre el deseo de honrar su memoria y el temor de profanarla» (Zulueta, 1915: 45), y a sabiendas de que la obra principal de don Francisco fue hecha y disfrutada por los que en vida lo conocieron, intentaremos pagar la eterna deuda de gratitud que, como educadores, sin duda, tenemos con él: 
A algo más que querer y a llorarle está usted obligado. Cumpla usted con su deber. [...] Lleve usted a D. Francisco a la escuela para que sus discípulos le conozcan y le quieran como le conoce y quiere usted. Les hará usted un gran bien. Vivo, fué [sic] D. Francisco un gran maestro. De nosotros depende que lo siga siendo aun después de muerto (Llorca, 1915: 255-256).

\section{Bibliografía citada}

Alas ArgüELLES, L., «Nuestro don Francisco», BILE [Boletín de la Institución Libre de Enseñanza], 665 (1915), pp. 254-255.

Altamira, R., «Giner de los Ríos», BILE, 659-660 (1915a), pp. 59-62.

- Giner de los Ríos. Educador, Valencia, Prometeo, 1915b.

BAllester-Soto, V., «El Maestro de Maestros que se fue. Don Francisco Giner de los Ríos», BILE, 678 (1916), p. 287.

Bernaldo De Quirós, C., «La clase de D. Francisco», BILE, 663 (1915), pp. 186-188.

Castillejo, J., Wars of ideas in Spain. Philosophy, Politics and Education, London, John Murray, 1937.

DiCENTA, J., «La última lección», BILE, 659-660 (1915), pp. 43-44.

«El aniversario de D. Francisco Giner de los Ríos», El Día. Diario de la Noche, 18 de febrero de 1917, p. 1.

«Estudiante y maestro», El País, 19 de febrero de 1915, pp. 1-2.

García Morente, M. \& F. DE los Ríos, «El Pedagogo», BILE, 695 (1918), pp. 60-63.

García Velasco, J., Francisco Giner de los Ríos. Un andaluz de fuego, León, Fundación Sierra Pambley, 2011.

GINER DE LOS Ríos, F., Pedagogía universitaria, Barcelona, Manuales Soler, c. 1910.

- BILE, 714 (1919), pp. 287-288.

- Obras completas, VII: Estudios sobre educación, Madrid, La Lectura, 1922.

- En el cincuentenario de la Institución Libre de Enseñanza, Madrid, Olózaga, 1926.

- Ensayos y cartas. Edición homenaje en el cincuentenario de su muerte, México, Tezontle, 1965.

GONZÁlez GERAldo, J. L., «Nuevos tiempos, viejas ideas: la influencia de la ILE en los roles de maestros y estudiantes de escuela del siglo XXI», CITE 2011. XII Congreso Internacional de Teoría de la Educación, 2011, pp. 1-20.

- Hacia una universidad más humana. ¿Es superior la educación superior?, Madrid, Biblioteca Nueva, 2014.

Horrillo, A., «La clase de D. Francisco Giner», BILE, 858 (1931), pp. 315-316. 
Jara Urbano, A., «Un día triste», BILE, 734 (1921), pp. 158-159.

JimÉnEZ GARCíA, A., El krausismo y la Institución Libre de Enseñanza, Madrid, Cincel, 1987.

JiMÉNEZ LANDI, A., La Institución Libre de Enseñanza y su ambiente. Los orígenes de la Institución, I, Madrid, Ministerio de Educación y Cultura, 1996a.

- La Institución Libre de Enseñanza y su ambiente. Los orígenes de la Institución, II, Madrid, Ministerio de Educación y Cultura, 1996b.

- La Institución Libre de Enseñanza y su ambiente. Los orígenes de la Institución, IV, Madrid, Ministerio de Educación y Cultura, 1996c.

JimÉnEz MANTECón, J. R. [Juan Ramón Jiménez], «Elegía a la muerte de un hombre», BILE, 782 (1924), p. 224.

JUNCAL, J., «El maestro y su obra», BILE, 659-660 (1915), pp. 70-72.

«La figura de actualidad», BILE, 740 (1921), pp. 351-352.

LÁzAro y Junquera, L., «Don Francisco Giner de los Ríos», BILE, 666 (1915), pp. 287-288.

LlorCA, A., «Don Francisco Giner de los Ríos», BILE, 665 (1915), pp. 255-256.

LÓPEZ-MORILlas, J., «El arte de hacer hombres» [conferencia], Fundación

Juan March, 1989; <http://www.march.es/conferencias/anteriores/voz.aspx? pl=21890\&l=2> [consulta: 30 abril 2015].

Machado, A., «D. Francisco Giner de los Ríos», BILE, 664 (1915), pp. 220-221.

MARTín GRANizO, L., «El genio de la pedagogía», BILE, 674 (1916), pp. 158-159.

MARTíN-SÁNCHEZ JULIÁ, F. et al., Una poderosa fuerza secreta. La Institución Libre de

Enseñanza, San Sebastián, Editorial Española, 1940.

MESA, E., «Giner», BILE, 721 (1920), p. 127.

Molero PintAdo, A., «El modelo del maestro en el pensamiento de la Institución Libre de Enseñanza», Revista Interuniversitaria de Formación del Profesorado, 0 (1987), pp. 7-22.

- La Institución Libre de Enseñanza: un proyecto de reforma pedagógica, Madrid, Biblioteca Nueva, 2000.

ORTEGA Y GASSET, J. [1930], Misión de la Universidad y otros ensayos de educación y pedagogía, Madrid, Alianza, 1982.

Otero UrtazA, E., Manuel Bartolomé Cossío. Trayectoria vital de un educador, Madrid, Amigos de la Residencia de Estudiantes / CSIC, 1994.

PAlAcios, L., «La Cátedra de Giner», BILE, 791 (1926), pp. 59-63.

PijoÁn, J., «Mi Don Francisco Giner (1906-1910)», BILE, 813 (1927a), pp. 383-384.

- Mi Don Francisco Giner (1906-1910), San José de Costa Rica, Repertorio Americano, $1927 \mathrm{~b}$.

Programa de la Institución Libre de Enseñanza. Primer Centenario 1876-1976. Madrid, Revista de Occidente, 1976. 
REYES, A., «Don Francisco Giner de los Ríos. Hoy se cumple el X aniversario de su fallecimiento», BILE, 783 (1925), pp. 181-182.

SÁNCHEZ, B., «El maestro de los maestros», BILE, 700 (1918), pp. 209-211.

SEgOviA, A. de, «D. Francisco ha muerto», BILE, 659-660 (1915), pp. 81-82.

UREÑA, R., «El Catedrático», BILE, 667 (1915), p. 317.

ZozAYA, A., «Don Francisco el Magno», BILE, 659-660 (1915), p. 64.

ZuluetA, L., «Don Francisco», BILE, 659-660 (1915), pp. 45-48.

Fecha de recepción: 30-4-2015

Fecha de aceptación: 3-10-2015 


\title{
FRANCISCO GINER, ESTUDIANTE DE BACHILLERATO EN EL INSTITUTO JORGE JUAN DE ALICANTE (UNA NOTA DOCUMENTAL)
}

\author{
RAQUEL LÓPEZ SÁNCHEZ \\ Universidad Autónoma de Madrid
}

\section{Resumen}

El presente estudio aborda la etapa formativa de Francisco Giner de los Ríos en el Instituto Jorge Juan de Alicante, durante el periodo comprendido entre 1848 y 1852. Para ello, tomamos como punto de partida el expediente académico del entonces alumno Francisco Giner, dirigiendo una mirada retrospectiva hacia su trayectoria escolar en la capital alicantina, y proyectándola hacia la profunda reforma de la sociedad que abordó el polifacético docente mediante la metamorfosis del sistema educativo estatal.

Palabras clave: Francisco Giner de los Ríos; Instituto Jorge Juan de Alicante; expediente académico.

\begin{abstract}
The following study approaches the formative stage of Francisco Giner de los Ríos in the Secondary School Jorge Juan of Alicante, during the period understood between 1848 and 1852. We take as a point of departure the academic record of Francisco Giner as a pupil, directing a retrospective look at his academic history in the capital of Alicante, and projecting it towards the deep reform of the society that the versatile teacher approached by means of the metamorphosis of the State's educational system.
\end{abstract}

Keywords: Francisco Giner de los Ríos; Secondary School Jorge Juan of Alicante; academic record. 
—Sí, Augusto, sí — prosiguió don Avito-; la vida es la única maestra de la vida; no hay pedagogía que valga. Solo se aprende a vivir viviendo, y cada hombre tiene que recomenzar el aprendizaje de la vida de nuevo...

Niebla, Miguel de UnAmuno

Adentrarse en la irrepetible figura de Francisco Giner de los Ríos es convocar el reconocimiento del pedagogo que «estimulaba el alma de sus discípulos - de los hombres o de los niños- para que la ciencia fuese pensada, vivida por ellos mismos» (Machado, 1994: 295). El vitalismo regeneracionista de las palabras de Antonio Machado hacia el que fuera su maestro en la Institución Libre de Enseñanza dibuja con nitidez el talante comprometido de don Francisco con la dignificación del pensamiento y del trabajo en muy variados ámbitos del saber humano. La plenitud de sus enseñanzas y el esmero vocacional que calcifican en la esperanza krausista frente a la anemia intelectual de la vida española perfilan el proyecto de Giner hasta copar la formación de un «hombre dueño de sí mismo, capaz de trabajar y valerse por sí; un núcleo de fuerzas espirituales con iniciativa individual, una persona libre» (Giner de los Ríos, 1990: 134-135).

A pesar de la amplísima cantera de disciplinas sobre las que teorizó don Francisco Giner, uno de los vacíos documentales que acusan la trayectoria del enseñante es precisamente el que resulta del envés de su espíritu «laborioso y activo» en el ámbito de la docencia (Machado, 1994: 296): su faceta como alumno. Sabemos mucho de su función como enseñante; sin embargo, la juventud —-mejor aún, la etapa formativa del Francisco Giner niño- es un territorio en alguna medida por recorrer.

Un acercamiento apresurado a su biografía nos sitúa de inmediato en su Ronda natal, en la provincia de Málaga. Don Francisco nace allí en 1839 en el seno de una familia acomodada. A la temprana edad de nueve años su padre, el empleado de Hacienda Francisco Giner de la Fuente, fue destinado a Alicante, donde la familia se estableció en el número 25 de la Plaza Juan de Dios. A partir de este momento, los esbozos biográficos y los empréstitos de las investigaciones que calibran los avatares de su carrera académica nos tienen acostumbrados a pasar de soslayo por el interesante - y esto es así por lo inédito- capítulo de la etapa de formación del niño Francisco Giner una vez hubo ingresado en el Instituto Provincial de 2. ${ }^{a}$ Enseñanza de Alicante, el actual Instituto de Educación Secundaria Jorge Juan (que, en el momento en que redacto estas líneas, dirige el profesor de Latín y Griego D. José Miguel Baeza Bueno). El expediente académico del que firmaba por entonces como Francisco Giner y Ríos, cedido por el 
Instituto, permite que una mirada retrospectiva por este conjunto documental delinee con alguna precisión la memoria de don Francisco Giner en tierras de Alicante.

Previamente, y en solidaridad con esta tarea de descortezar la estadía educativa de don Francisco Giner en Alicante, la ocasión es propicia para ubicar en los anaqueles de la historia una realidad urbana que, a menudo, escapa a quienes transitamos por las calles de nuestras ciudades. Reconociendo así el mapa arquitectónico de la provincia, el Instituto de Segunda Enseñanza en que cursó don Francisco Giner se situaba en el número 9 de la calle Villavieja, frente a las recias estructuras de la Iglesia - hoy día Basílica - de Santa María en la plaza homónima. La Asegurada $^{1}$, como se conocía al caserón que el Ayuntamiento, concretamente el arquitecto Emilio Jover, había acondicionado en 1843 para albergar una escuela, constituye la construcción civil más antigua de Alicante (Cerdán Tato, 1993). Edificada en las postrimerías del siglo XVII «con la finalidad de almacenar grano y harinas para afrontar hambrunas» (Valdés, 2010)², es en 1845 cuando su sobria armazón se reviste de pupitres y encerados para acoger a un total de noventa alumnos matriculados durante el primer año académico. Suerte de epifanía o, tal vez, necesidad de escamotear los cedazos del tiempo y del olvido, no resulta difícil imaginar a un presuroso don Francisco Giner atravesar la Plaza de Santa María para recibir sus lecciones.

Así las cosas, el repertorio de documentos que conforman el expediente da cumplida cuenta de su instrucción en el centro durante el periodo comprendido entre 1848 y 1852, fecha esta última en la que culmina sus estudios con la obtención del grado de Bachiller en Filosofía, de

1. Viravens y Pastor (1876: 249) escribe: «El frontispicio principal se hizo de piedra de la cantera de San Julián: en él había ocho ventanas con rejas, en cuyo intermedio superior se puso en el centro el escudo de Armas de esta Ciudad, grabado en piedra [...]. La puerta de la Asegurada forma un arco, que exorna una sencilla portada con pedestales y pilastras; y sobre el cornisón que sostienen se colocó una lápida con los nombres del Justicia, Jurados, Racionero y Escribano-Secretario, que estaban al frente del Municipio en el año 1685 en que se hizo la referida casa».

2. Cfr. Jaén i Urban (1999: 33): «Fue levantada por el municipio para uso público, por lo que aparece el escudo de Alicante en la fachada. A lo largo de su historia ha sido utilizado para usos diversos tales como archivo municipal, escuelas, instituto y escuela de comercio hasta 1955. [...] Las plantas son diáfanas, disponiendo los entramados de los pisos en tres crujías paralelas a fachada que descansan en amplios arcos de medio punto y pilastras, todo de sillería, sin ornamentación, creando un espacio donde el valor arquitectónico se basa en la calidad constructiva». 


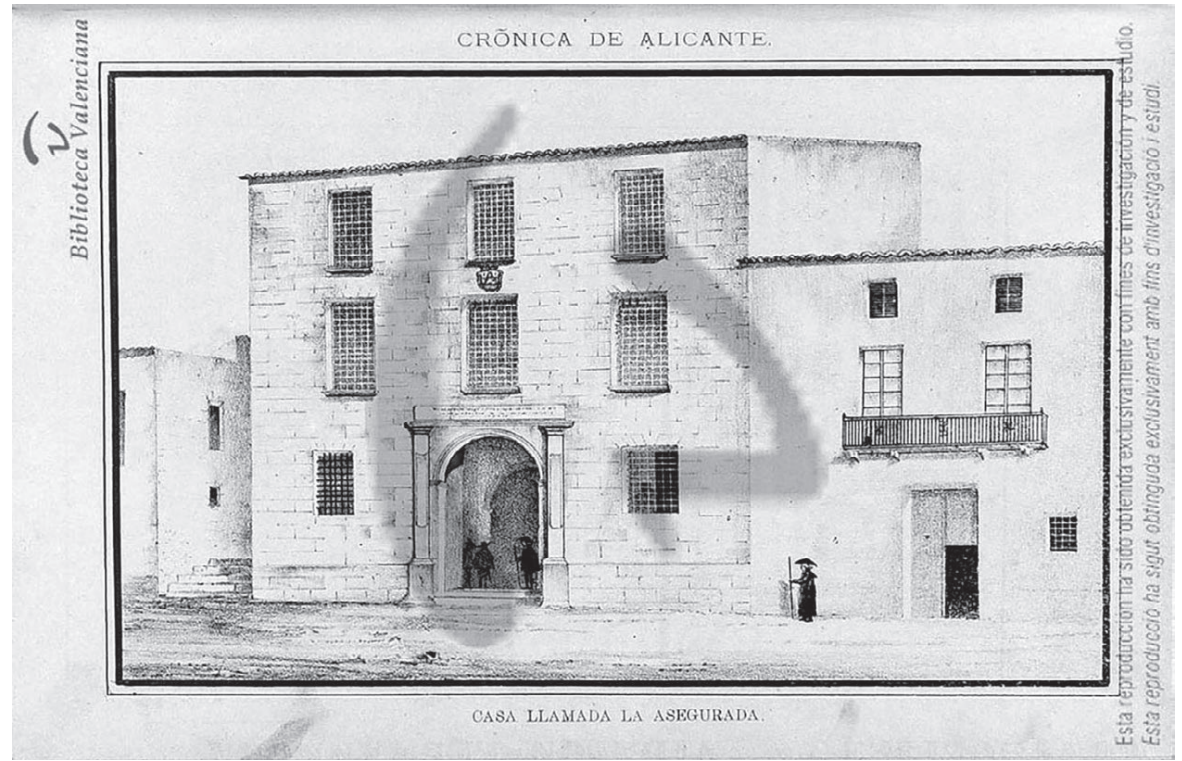

Imagen 1. La Asegurada, en la Crónica de Rafael Viravens y Pastor (1876).

conformidad con el Plan de Instrucción Pública promulgado por Pedro José Pidal y Antonio Gil de Zárate en 1845.

Apenas emprendido el viaje hacia Levante, el 30 de octubre de 1848 Francisco Giner remitió al director del Instituto una instancia solicitando su incorporación al centro, que durante esos años dirigía D. Agustín González, así como traslado de expediente desde el Colegio de Santo Tomás de Aquino en la ciudad de Cádiz — incorporado a la Universidad de Sevilla_-, en el que había cursado su primer año de Segunda Enseñanza Elemental y había comenzado también el segundo curso escolar. La instancia iba acompañada de un certificado que nueve días antes había redactado en Cádiz don Vicente Gómez de Bustamante, profesor secretario del colegio gaditano, que acreditaba la matrícula del estudiante en el centro y encarecía las notorias facultades del joven solicitante. El texto reza así:

Don Vicente Gómez de Bustamante Académico de Honor y Catedrático de Matemáticas de la Academia Nacional Gaditana de las Nobles Artes y de la Escuela especial de dicha ciencia en el Consulado de esta Plaza [...] Profesor Secretario del Colegio de 2. ${ }^{a}$ Enseñanza de $1 .^{a}$ Clase de Santo Tomás de Aquino de esta Ciudad e individuo de varias corporaciones literarias. 


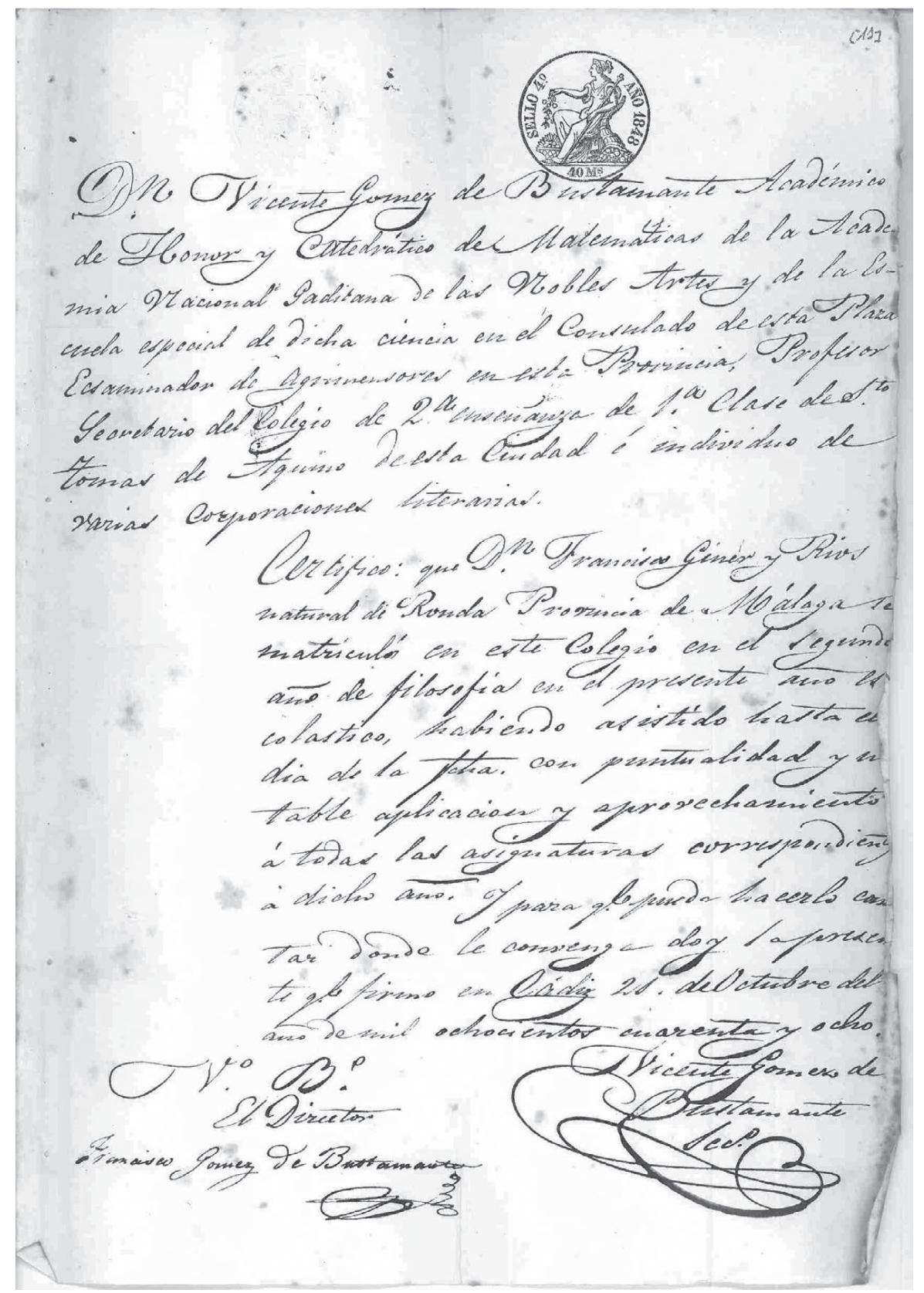

Imagen 2. Original del certificado redactado por Don Vicente Gómez de Bustamante. 
Certifico: que Don Francisco Giner y Ríos, natural de Ronda provincia de Málaga se matriculó en este Colegio en el segundo año de Filosofía en el presente año escolástico, habiendo asistido hasta el día de la fecha con puntualidad y notable aplicación y aprovechamiento a todas las asignaturas correspondientes a dicho año...

Con el visto bueno del director, otro miembro de la familia Gómez de Bustamante, don Francisco en esta ocasión, y con la anuencia del Secretario General de la Universidad de Sevilla, la petición de Francisco Giner se admitía a trámite, y el muchacho quedó matriculado en el centro alicantino el 13 de noviembre de 1848.

El primer año del recién llegado discente, Giner obtiene la calificación de sobresaliente en su segundo curso de Filosofía elemental, con lo que se dirige al director del Instituto solicitando autorización, conforme al reglamento, para poder optar al premio ordinario de excelencia académica. La instancia, registrada con fecha de 2 de julio de 1849, jalona un hito en el compendio documental de su expediente; se trata de la primera vez que, excepcionalmente, aparece rubricado «Francisco Giner de los Ríos».

Atestiguado así en la declaración del director, la petición de don Francisco Giner se resolvió favorablemente, aunque no puede decirse lo mismo del fallo del tribunal de catedráticos que ponderaban los ejercicios de Giner y de otro candidato al mismo premio, el finalmente galardonado don Estanislao Julián y Pérez.

Transcribimos a continuación un extracto del secretario en la sala de actas públicas de lo que a todas luces constituyó una contrariedad para Giner, habida cuenta de las aptitudes mostradas en sus ejercicios literarios, muy probablemente relacionados con la traducción y composición de textos en lengua castellana y latina, según se desprende de algunos originales que se recogen en el expediente:

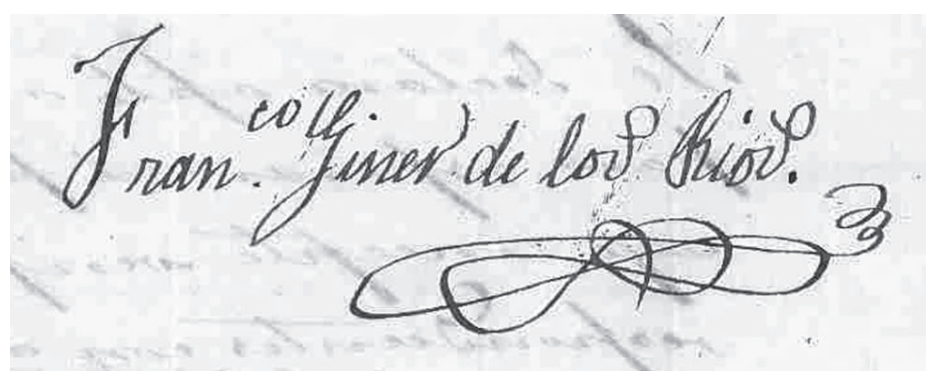

Imagen 3. Rúbrica original de don Francisco Giner de los Ríos. 


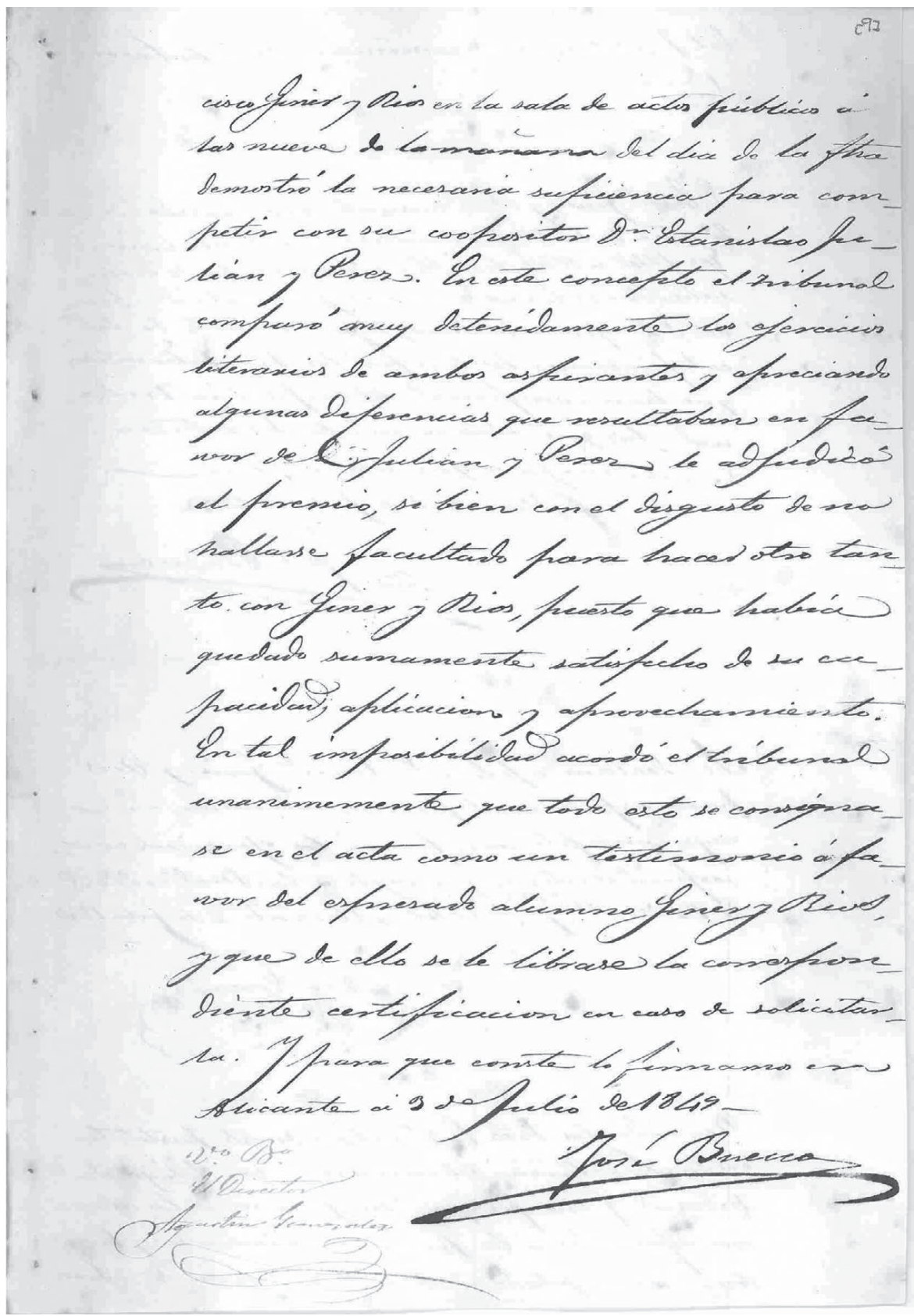

Imagen 4. Acta del secretario a propósito de la evaluación de los ejercicios optantes al premio ordinario. 
... En este concepto el tribunal comparó muy detenidamente los ejercicios literarios de ambos aspirantes y apreciando algunas diferencias que resultaban en favor de Julián y Pérez le adjudica el premio, si bien con el disgusto de no hallarse facultado para hacer otro tanto con Giner y Ríos, puesto que habrá quedado sumamente satisfecho de su capacidad, aplicación y aprovechamiento. En tal imposibilidad acordó el tribunal unánimemente que todo esto se consignase en el acta como un testimonio a favor del expresado alumno Giner y Ríos, y que de ello se le librase la correspondiente certificación en caso de solicitarla.

Posteriormente, el expediente adiciona un volumen de actas correspondientes a los cursos académicos 1849-1850, 1850-1851 y 1851-1852, que atañen al tercer, cuarto y quinto año de Filosofía elemental. En efecto, la relación de asignaturas, número de lecciones y calificaciones conforman un mosaico que concita dos circunstancias: la primera, la constancia y aprovechamiento de Francisco Giner en sus estudios durante los cuatro años que permaneció inscrito en el Instituto de la capital alicantina; la segunda, el testimonio del plan de estudios aprobado tres años antes de que el entonces niño Giner se trasladase con su familia a Alicante.

A esta luz, y como se ha dicho ya, los estudios de don Francisco Giner arraigan en las estructuras del Plan Pidal, sancionado nuevamente en 1857 por la archiconocida Ley Moyano, y con la que no transigiría la labor educacional de nuestro teórico y filósofo. De conformidad con la disposición firmada por el Ministerio de Gobernación a expensas del crédito concedido por Isabel II, el artículo 57 de la legislación refrendaba la fundación de un Instituto en cada capital de provincia, lo que sin duda vino a suponer la paulatina gravitación de la vida española hacia la cultura y la ciencia (Ruiz Berrio, 2008). El Instituto Jorge Juan de Alicante en que don Francisco Giner cursó el Bachillerato se convertía así, tras su inauguración en 1845 en la Asegurada, en el establecimiento que posibilitaba el acceso a la Enseñanza Media en la provincia.

Ahora bien, pese a la aparente panacea que suponía el nuevo plan de estudios decretado, la concepción de la paideia en que se formó don Francisco Giner se aparta mucho del principio epistemológico de texto vivo - como se consideró a los pedagogos deudatarios del krausismo- para encallar en el radicalismo eclesiástico rampante en la Década moderada (Álvarez Lázaro, 2005: 136; Ríos Urruti, 1949). En estos términos, y si cabe afirmarlo así, cláusulas como la que enseguida apuntamos constituyen ex aequo el germen de la decrepitud de un sistema educativo y de la modernidad pedagógica de los futuros prohombres de la ILE: «si se 


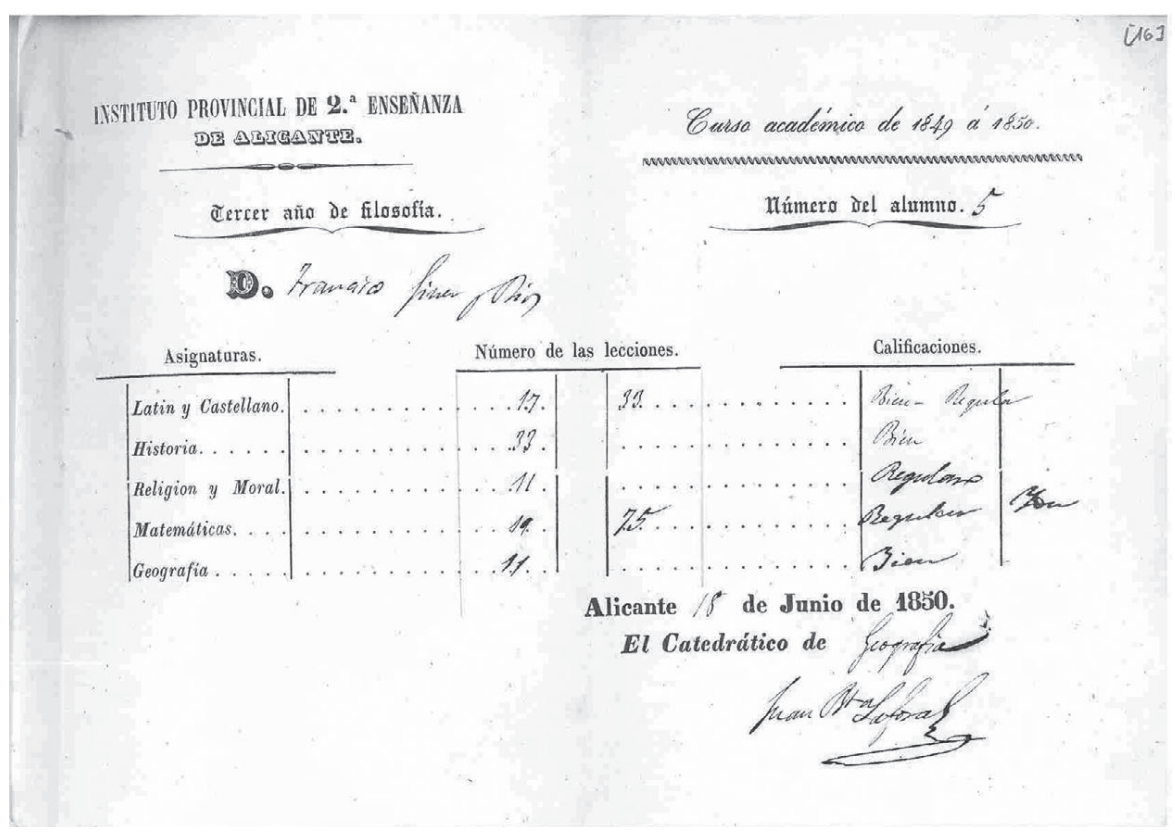

Imagen 5. Calificaciones de Francisco Giner en el curso académico de 1849 a 1850.

atiende a lo que exige una educación perfecta [...] sin la religión, sin que se labren desde la niñez sus sanas doctrinas en el corazón del hombre, perdidos serán cuantos esfuerzos se hagan para cultivar su entendimiento» (Real Decreto aprobando el Plan General de Estudios, de 17 de septiembre de 1845). Si estos planteamientos parecen circunstanciales, la etapa formativa de don Francisco Giner en Alicante evidencia el florecimiento de la enseñanza de carácter confesional, tal y como constata la materia de «Religión y Moral» diseminada en el decurso de sus estudios en el «Jorge Juan»; una asignatura esta, por cierto, que se resuelve mayoritariamente con la calificación de «regular».

Estos rasgos del Plan Pidal se subrayarían con la aprobación de la citada Ley Moyano en 1857, en un momento en que don Francisco Giner comenzaba a curtirse en su carrera académica y a imbuirse de las doctrinas krausistas a través de Nicolás Salmerón, Julián Sanz del Río y Fernando de Castro - a quienes conocería al filo de la década de los sesenta-. La Ley Moyano sería enjuiciada duramente años más tarde por don Francisco Giner en sus Escritos sobre la Universidad Española (1893-1904), cuyas 


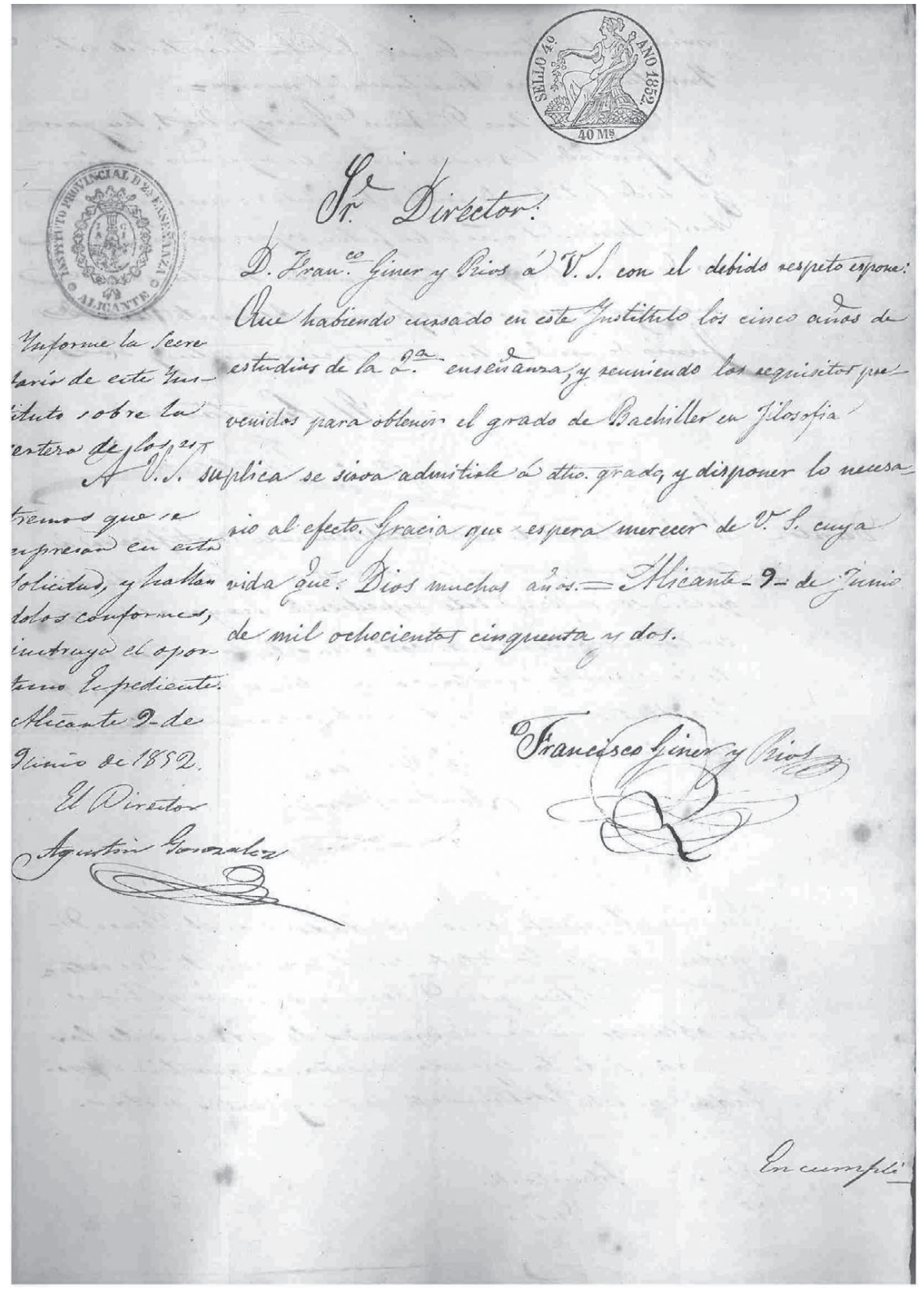

Imagen 6. Solicitud de Francisco Giner del grado de Bachiller en Filosofía en 1852. 
bases intelectuales ponían de manifiesto la confirmación de la nueva praxis pedagógica.

Al cabo, el expediente de Francisco Giner se cierra con las certificaciones correspondientes al logro del grado de Bachiller en Filosofía. Este apartado enlaza con una nueva instancia al director del centro, fechada el 9 de junio de 1852 y en la que razona lo que sigue:

D. Francisco Giner y Ríos a V. S. con el debido respeto expone: que habiendo cursado en este Instituto los cinco años de estudios de la 2. ${ }^{\mathrm{a}}$ enseñanza, y reuniendo los requisitos prevenidos para obtener el grado de Bachiller en Filosofía, a V. S. suplica se sirva admitirle a otro grado, y disponer lo necesario al efecto. Gracia que espera merecer de V. S. cuya vida de Dios muchos años.

Entendemos efectivamente que, cuando don Francisco Giner alude a sus «cinco años de estudios» en el Instituto alicantino, se está refiriendo a la culminación de la Segunda Enseñanza, que había comenzado, como ya se ha señalado, en la provincia de Cádiz. Estaba así en disposición de acceder a los estudios de Facultad mayor, para lo que marcharía sucesivamente a las Universidades de Barcelona — ciudad en que se forma en Jurisprudencia-, Granada — donde obtiene la licenciatura en Derecho-y la Central madrileña —en que recaló para realizar sus estudios de Doctorado en Filosofía del Derecho y Derecho Internacional-, llegando a alcanzar los muchos méritos que se le conocen en diversos campos del saber (PecesBarba Martínez, 1982).

El expediente recoge todo el proceso administrativo en virtud del cual Francisco Giner obtuvo el grado de Bachiller en Filosofía, desde la retribución de un total de cien reales por los derechos de examen hasta la asamblea constituida por el tribunal evaluador: el Catedrático comisionado por el Rector de la Universidad del distrito, el presidente de la Junta Inspectora, y tres Catedráticos de Latín y Castellano, y de Retórica y Poética. Finalmente, el 17 de junio de 1852 don Francisco Giner lograba «por todos los votos» el grado de Bachiller.

Con todo, cualquier intento de llegar al punto de término resulta vano. Lejos de agotarse esta panorámica de la trayectoria inicial de un Francisco Giner discente en una retrospección de carácter rememorativo, el fondo conservado en el Instituto Jorge Juan de Alicante incita a recrear una realidad cuya importancia estriba en los puntales del don Francisco Giner - conocimiento, sentimiento y voluntad — que transita estas páginas como un día lo hiciera por los montes del Guadarrama, allí donde —Machado dixit- «el maestro un día / soñaba un nuevo florecer de España». 


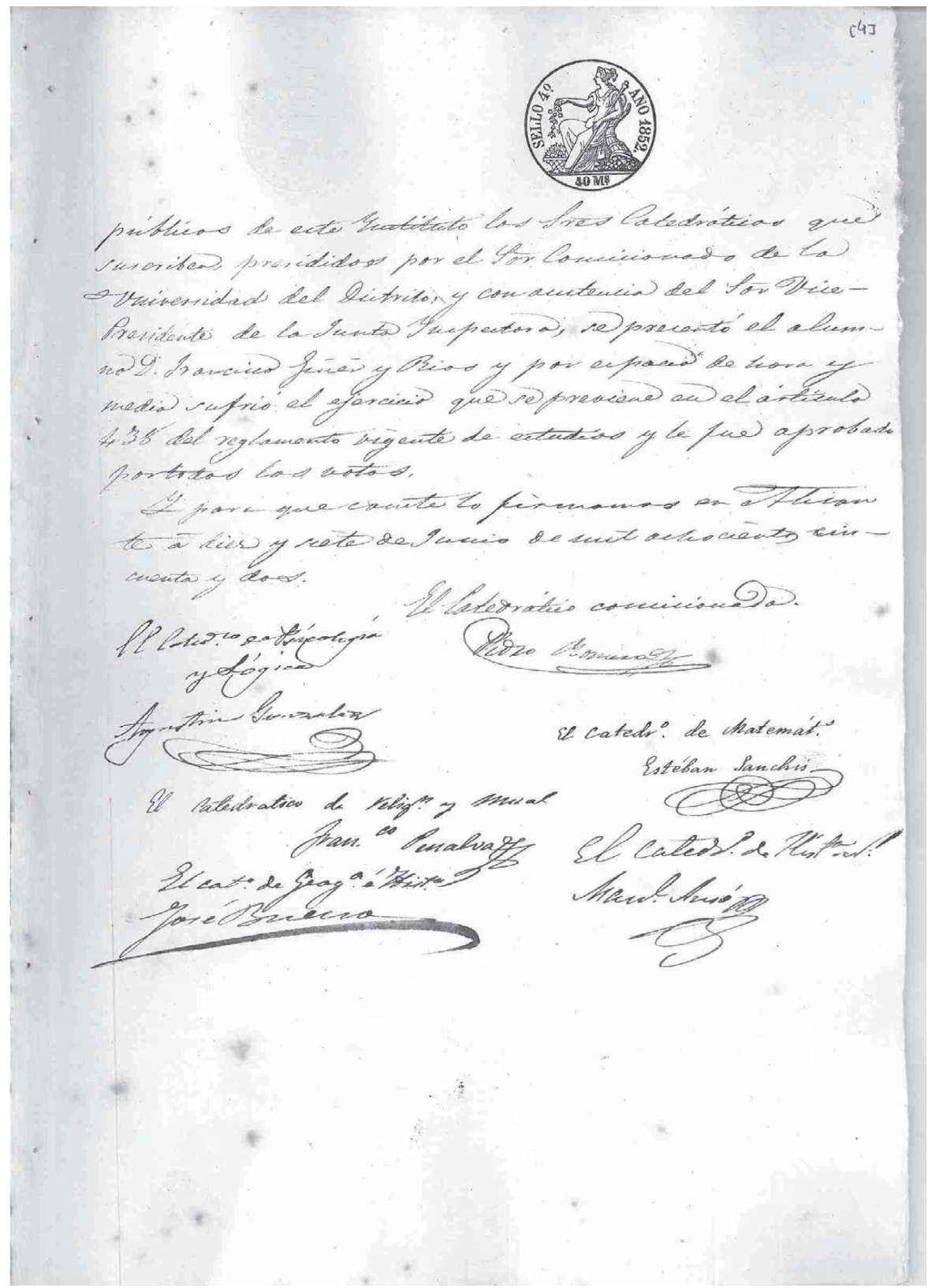

Imagen 7. Evaluación del tribunal a favor de la obtención del grado de Bachiller en Filosofía. 


\section{Bibliografía citada}

Álvarez Lázaro, Pedro F. \& José Manuel VÁzquez-Romero (eds.), Krause, Giner y la Institución Libre de Enseñanza: nuevos estudios, Madrid, Ministerio de Ciencia y Tecnología, 2005.

Cerdán TATO, Enrique, La Gatera [1993], Alicante, Biblioteca Virtual Miguel de Cervantes, 2003; <http://www.cervantesvirtual.com/obra-visor-din/la-gatera1994--0/html/> [consulta: 24 septiembre 2015].

GIL DE ZÁRATE, Antonio, De la instrucción pública en España, I, Madrid, Imprenta del Colegio de Sordo-mudos, 1855.

GINER DE LOS Ríos, Francisco, Ensayos menores sobre educación y enseñanza, 3 vols., en Obras completas, Madrid, Espasa-Calpe, 1927.

- Escritos sobre la universidad española, ed. Teresa Rodríguez de Lecea, Madrid, Espasa-Calpe, 1990.

JAÉN I URBAN, Gaspar (ed.), Guía de arquitectura de la provincia de Alicante, Alicante, Instituto de Cultura Juan Gil-Albert, 1999.

JiMÉNEZ-LANDI MARTíNEZ, Antonio, La Institución Libre de Enseñanza y su ambiente: periodo parauniversitario, II, Madrid, Editorial Complutense, 1996.

Machado, Antonio, Campos de Castilla, ed. Geoffrey Ribbans, Madrid, Cátedra, 1994.

Martínez Blanco, Antonio, La enseñanza de la religión en los centros docentes, Murcia, Universidad de Murcia, 1994.

PeCes-BARba MARTínez, Gregorio, «La enseñanza de la Filosofía del Derecho», Revista de la Facultad de Derecho de la Universidad Complutense, 5 (1982), pp. 99-110.

Puelles, Benítez, Manuel de, Política y educación en la España contemporánea, Madrid, UNED, 2011.

Real Decreto aprobando el Plan General de estudios, redactado por Antonio Gil de Zárate, 1845; <http://www.filosofia.org/mfa/fae845a.htm> [consulta: 24 septiembre 2015].

Ríos Urruti, Fernando de los, El pensamiento vivo de Francisco Giner, Buenos Aires, Losada, 1949.

Ruiz BERRIO, Julio, «El Plan Pidal de 1845: Los institutos públicos, dinamizadores de las capitales de provincia», Participación Educativa, 7 (2008), pp. 28-38.

Tiana Ferrer, Alejandro, Gabriela Ossenbach SAUter \& Florentina SAnZ FERnÁNDEZ, Historia de la educación (Edad Contemporánea), Madrid, UNED, 2012.

VALDÉS, Andrés, «La casa superviviente», Información, 2011; <http://www.diarioinformacion.com/cultura/2011/01/02/casa-superviviente/1080504.html> [consulta: 27 septiembre 2015]. 
Viravens y PASTOR, Rafael, Crónica de la muy ilustre y siempre fiel ciudad de Alicante, Alicante, Imprenta de Carratalá y Gadea, 1876.

Fecha de recepción: 30-4-2015

Fecha de aceptación: 3-10-2015 


\title{
LA INFLUENCIA DE LA INSTITUCIÓN LIBRE DE ENSEÑANZA EN RODOLFO LLOPIS
}

\author{
ADELINA SiRVENT GÁRRIGA \\ Doctora en Sociología
}

\section{Resumen}

Rodolfo Llopis, influido por los principios pedagógicos de la Institución Libre de Enseñanza, intentó renovar la educación: primero como docente en la Escuela Normal de Cuenca, y más tarde como director general de Primera Enseñanza, coincidiendo con el bienio reformista de la Segunda República. Su gran deseo de cambio social le llevó a luchar por la educación y la democracia como pilares fundamentales para la regeneración social, política, pedagógica y cultural. Su formación en la Escuela Superior de Magisterio le puso en contacto con los profesores defensores del ideario de la Institución Libre de Enseñanza, y las influencias de Francisco Giner de los Ríos y Manuel Bartolomé Cossío definieron su perfil de docente y político institucionista.

Palabras clave: Rodolfo Llopis; Institución Libre de Enseñanza; Escuela Superior de Magisterio; Segunda República española; principios educativos.

\begin{abstract}
Rodolfo Llopis, influenced by the pedagogical principles of the Institución Libre de Enseñanza, tried to renew education; first as a teacher in the Normal School of Cuen$\mathrm{ca}$, and later as managing director of Primary Education, coinciding with the reformist biennium of the Second Republic. His great desire for social change led him to fight for education and democracy as fundamental pillars for social, political, educational and cultural regeneration. His training at the School of Education put him in touch with teachers who advocated for the ideology of the Institución Libre de Enseñanza, while the influences of Francisco Giner de los Ríos and Manuel Bartolomé Cossío defined his educational and political profile.
\end{abstract}

Keywords: Rodolfo Llopis; Institución Libre de Enseñanza; College of Education; Second Spanish Republic; educational principles. 


\section{La Escuela Superior de Magisterio}

Rodolfo Llopis ingresó en la Escuela Superior de Magisterio ${ }^{1}$ en 1916; perteneció a la octava promoción. Se presentó al examen de ingreso en la convocatoria de junio y obtuvo plaza para cursar los estudios en la sección de Letras. Finalizó sus estudios en 1919. Ejerció como profesor de Geografía en la Escuela Normal de Cuenca hasta noviembre de 1930, año en que regresó a Madrid para dedicarse de lleno a la política.

La Escuela Superior de Magisterio gozó de un gran prestigio, y a ella acudieron maestros y licenciados interesados en completar su formación pedagógica con las teorías más innovadoras. También Rodolfo Llopis quiso estudiar en este centro, donde conoció las ideas de los institucionistas e hizo grandes amigos entre las figuras más destacadas de la ILE. La influencia que recibió le marcó a lo largo de su vida.

La Escuela contaba con profesores como Ricardo Beltrán y Rózpide, Luis de Hoyos, Domingo Barnés, Luis de Zulueta y Pablo Martínez Strong. Todos tenían una amplia cultura, gran vocación pedagógica y profundos valores humanos, e hicieron de esta Escuela un centro modelo, donde el reducido número de alumnos permitía una enseñanza activa y una estrecha relación entre alumnos y profesores. Estos estaban unidos en su común deseo de responder al espíritu que dio lugar a la creación de la Escuela Superior de Magisterio: elevar el nivel cultural de las Normales $y$, consecuentemente, el de la enseñanza primaria española. Los profesores, influidos por las ideas de la Institución Libre de Enseñanza, quisieron desde el principio poner a sus alumnos en contacto directo con el medio circundante, mediante visitas, excursiones y viajes. Adolfo A. Buylla, director de la Escuela, escribía en 1912: «Respondiendo a aquella necesidad que caracteriza a nuestra Escuela de vivir la enseñanza y de enseñar en vivo, adviértase que muchos [trabajos de los alumnos] se realizan del natural, ya visitando monumentos y museos de arte, bien coleccionando ejemplares de los distintos reinos» (en Ferrer, 1973: 204-205).

1. El Real Decreto de 10 de septiembre de 1911 cambió el nombre de la Escuela, que pasó a llamarse Escuela de Estudios Superiores del Magisterio. Los ministros Amalio Gimeno, Santiago Alba y Francisco Bergamín, a través de sucesivas disposiciones, fueron introduciendo mejoras en la Escuela Superior de Magisterio. Una de ellas era la concesión de becas a todos los alumnos matriculados, y otra que, cuando acabasen sus estudios, saldrían directamente colocados como profesores de Escuela Normal o como inspectores de Enseñanza Primaria. Rodolfo Llopis realizó sus estudios por el Plan de 1914 La octava promoción en la sección de Letras estaba formada por nueve alumnos y siete alumnas. 
En la sección de Letras, la Geografía fue una asignatura importante. Se impartieron las siguientes materias: «Nociones generales de Geografía y Geografía regional», «Metodología de la enseñanza de la Geografía», «Geografía de España», «Geografía universal», «Ampliación de Geografía de España», «Cosmografía y Física del Globo», «Fisiología e Higiene» y «Agricultura», esta última solo para maestros, y para las maestras «Economía doméstica». En 1922, se creó el «Seminario especial de Geografía económica de España $»^{2}$, que estaba dirigido a los alumnos que finalizaban sus estudios en este centro y a los Catedráticos de Geografía de las Normales e Institutos de Enseñanza Media. Ricardo Beltrán y Rózpide organizó este seminario desde su creación hasta 1928. La duración era de tres meses, desde marzo hasta mayo. Se realizaban reuniones semanales «de cotejo y relación de los trabajos realizados de forma individual y colectiva». El objetivo que se perseguía era «organizar y centralizar el estudio sistemático de las regiones españolas, en especial las menos conocidas, desde el punto de vista de la Geografía humana, con especial atención a las cuestiones económicas» (Rodríguez, 1997: 91).

La Escuela Superior de Magisterio formó a profesores que intentaron renovar la enseñanza a través de disciplinas como la Geografía: «Son ellos quienes, a lo largo del tercer y cuarto decenios, estimulan las visitas y excursiones, desarrollan la utilización del mapa, crean museos geográficos e impulsan los estudios locales, las llamadas "monografías de aldea" » (Vilà, 1989: 89-90). Estos profesores difundieron los contenidos, actividades y métodos geográficos en las diferentes Escuelas Normales donde ejercieron: Isidoro Reverte, en las Normales de Albacete y Murcia; Miquel Santaló, en Segovia y Gerona; Leoncio Urabayen, en Pamplona; Pedro Chico, en Soria y Madrid; y Rodolfo Llopis, en Cuenca y Madrid.

Ricardo Beltrán y Rózpide instauró la costumbre de que los alumnos realizaran un trabajo sobre un hecho geográfico: «Un pueblo, una comarca, un género de vida...». Así se iniciaron las monografías geográficas. Estas partían de distintos cuestionarios que indicaban los datos que debían recoger, como el de C. M. Jourdan y el de Albert Demangeon para una investigación regional. Pero, sobre todo, utilizaban el que Luis de Hoyos elaboró para el estudio geográfico de pequeñas localidades y comarcas (Vilà, 1989: 96).

Los trabajos de investigación que desarrollaban los alumnos en los seminarios eran muy importantes, así como las memorias de fin de

2. R. O. de 29 de noviembre de 1922 y R. O. de 20 de abril de 1923.

Anales, 27 (2015), pp. 215-226 
carrera, de planteamiento similar al de las Tesis Doctorales realizadas en la Universidad. La mayoría de los alumnos optaban por monografías geográficas de ámbito local sobre cuestiones metodológicas, clima..., y algunas se dedicaron a la Geografía histórica. Luis de Hoyos Sainz y Ricardo Beltrán y Rózpide dirigieron la memoria de fin de carrera de Rodolfo Llopis, quien eligió un pueblo costero de su provincia natal, Alicante: «Santa Pola. Monografía geográfica» (1919). Estos trabajos fomentaron el interés por la investigación en los alumnos, quienes, más tarde, siendo ya profesores, siguieron ejecutando y promoviendo estudios similares en diferentes lugares de España. Ello supuso la materialización de la investigación sistemática del territorio español, la creación de una Geografía humana de España. Hay que destacar entre los alumnos a Isidoro Reverte, Pedro Chico, Juan Leoncio Urabayen, Miguel Santaló y Rodolfo Llopis, por la labor realizada en diversos trabajos sobre Geografía.

En la Escuela Superior de Magisterio, Rodolfo Llopis entró en contacto con los representantes de la ILE: Luis de Zulueta, su profesor de Pedagogía, y Manuel Bartolomé Cossío. Sobre ellos realizó declaraciones que expresaban su agradecimiento y su influencia. Del primero dijo que preparaba sus clases concienzudamente y que estas se continuaban fuera del aula con inolvidables conversaciones: «Lo recordamos inquietando nuestras conciencias, abriendo nuestros espíritus a un mundo de insospechadas posibilidades. Lo recordamos planteando los más graves problemas morales...» («Nuestros maestros: a Zulueta», en Revista Escuelas Normales, enero de 1928). Y encontramos artículos sobre Manuel Bartolomé Cossío en los que dejó patente su amistad y admiración. En el artículo que dedicó a Fernando de los Ríos en 1946 también habló de aquel y comentó que, cuando terminó el primer curso como profesor de la Escuela Normal de Cuenca, hizo «examen de conciencia. Recapitulé mi actividad pedagógica». Al considerar que había fracasado, decidió visitar a Manuel Bartolomé Cossío para comentárselo (Llopis, 1949): «Y el Sr. Cossío [...] me fue rebatiendo uno a uno todos mis legítimos escrúpulos, animándome, alentándome, convenciéndome de que los frutos de la obra pedagógica no se pueden recoger al día siguiente».

\section{Rodolfo Llopis y los principios pedagógicos de la Institución}

La Institución Libre de Enseñanza tenía entre sus principios educativos esenciales la enseñanza neutral en cuanto a cuestiones políticas y religiosas. Los institucionistas querían «sembrar en la juventud, con la más absoluta libertad, la más austera reserva en la elaboración de sus normas 
de vida y el respeto más religioso para cuantas sinceras convicciones consagra la historia». Rodolfo Llopis, de acuerdo con ese principio fundamental, decía en una intervención parlamentaria en defensa de una enmienda socialista al artículo 48 de la Constitución: "Cueste lo que cueste, hay que respetar la conciencia del niño. [...] [E]ntendemos que la forma de respetar la conciencia del niño es que se quede a la puerta de la escuela toda clase de dogmatismo, lo mismo del tipo religioso...» (20 de octubre de 1931).

La Institución fomentaba en sus alumnos el interés hacia una amplia «cultura general, múltiplemente orientada». Se proponía que los alumnos asimilaran los conocimientos de humanidades que cada época exigía y una educación profesional de acuerdo con sus aptitudes y vocación, «escogida más a conciencia de lo que es uso». Quería prepararlos para que fueran científicos, literatos, médicos...; pero sobre todo quería prepararlos para ser hombres, "personas capaces de concebir un ideal, de gobernar con sustantividad su propia vida y de producirla mediante el armonioso consorcio de todas sus facultades». Rodolfo Llopis escribía al respecto: «La Institución despertaba en sus alumnos el interés hacia la cultura general, siguiendo una orientación educativa que consiste no en aprender las cosas sino en aprender a hacerlas» (1955: 64). Para lograrlo quería que, en el cultivo del cuerpo y del alma, nada les fuese ajeno. Les interesaba el desarrollo intelectual, físico y social, la salud y la higiene, las condiciones estéticas, la formación de la voluntad; y además, «la corrección y nobleza de hábitos y maneras; la amplitud, elevación y delicadeza del sentir; la depuración de los gustos estéticos, la humana tolerancia, la ingenua alegría, el valor sereno, la conciencia del deber, la honrada lealtad, la formación, en suma, de caracteres armónicos dispuestos a vivir como piensan» (1935: 37-38).

Rodolfo Llopis afirmaba que quien pretendiera hacer la historia de la Institución tendría que hacer la historia de España, pues, «aunque ajena a la política militante», por ella desfilaron, en demanda de consejo, desde el maestro rural que quería resolver una dificultad pedagógica «hasta los personajes más encumbrados, a quienes angustiaban difíciles negocios de Estado» (1935: 37). Él, que admiraba profundamente la labor pedagógica de la ILE, había buscado consejo en Manuel Bartolomé Cossío durante su primer curso como profesor, y seguramente lo hizo, aunque no tengamos constancia de ello, en su etapa como Director General.

Siguiendo la estela de la ILE, en la política educativa de la Segunda República se dieron los primeros pasos para que el alumno recibiera una 
educación en valores y se atendieron aspectos educativos que tradicionalmente la escuela pública no contemplaba. En 1931 Rodolfo Llopis envió una circular a los centros en la cual podemos leer: "La supresión de la enseñanza religiosa con carácter obligatorio no debe significar el abandono en la dirección moral de los escolares; por el contrario, [...] el maestro se esforzará, ahora más que nunca, [...] en inspirar en los niños un elevado ideal de conducta» (Circular de la Dirección General de Primera Enseñanza, 13 de mayo de 1931). Ese elevado ideal de conducta se fomentaría, entre otras actividades, con aquellas que la Segunda República creó como complementarias a la escuela: cantinas, colonias escolares y viajes. Respecto a las cantinas, Rodolfo Llopis defendió su función esencial: la educativa. En cuanto a las colonias escolares, el Ministerio de Instrucción Pública organizó una colonia internacional en La Granja, donde niños franceses, ingleses y alemanes convivieron con los niños españoles. En el mismo palacio donde tantas veces se habló de guerras, la República fomentó la conciencia pacifista internacional, al promover actos de esa naturaleza. En los viajes escolares los maestros y los niños hicieron multitud de excursiones por varias provincias españolas. Estas experiencias sirvieron para que unos y otros fueran creando vínculos fraternales al mismo tiempo que enriquecían su cultura: «Queremos que la enseñanza esté fecundada por esos dos principios: el principio del trabajo y el principio de la solidaridad humana» (Llopis, 1933: 227-228).

La educación estética era una disciplina importante, y su aprendizaje se realizaba a través de la contemplación directa de la obra de arte. Con frecuencia, los sábados se veía a alumnos de la Institución recorriendo museos para completar el estudio de esta materia. Visitaban las salas de arte que Madrid les ofrecía a la búsqueda de la lección vivida. Cuando la Historia del Arte estaba empezando a ser disciplina académica en diversos países europeos, la Institución ya la había introducido como elemento de estudio. El Programa institucionista así lo había establecido: «Trabajo intelectual sobrio e intenso, juego corporal al aire libre; larga y frecuente intimidad con la Naturaleza y con el arte» (Programa de la ILE, 1934: 10).

Los principios pedagógicos que la ILE defendió ayudaron a que la Geografía ocupase el lugar que merecía en el sistema educativo. Los institucionistas utilizaron las excursiones escolares como un elemento esencial del proceso de formación. En ellas, fomentaron la observación directa y los conocimientos empíricos que proporcionaban una enseñanza interdisciplinar, intuitiva, continua, activa e integral. Para las clases de Ciencias Naturales y de Ciencias Sociales, también se recurría a la observación 
directa, y los alumnos salían de sus aulas en busca de las fuentes del conocimiento. De las excursiones, nos dice Manuel Bartolomé Cossío que «ofrecen con abundancia los medios más propicios, los más seguros resortes para que el alumno pueda educarse en todas las esferas de su vida» (Cossío, 1966: 25; y Programa de la ILE, 1934: 16-17). Rodolfo Llopis hacía referencia a este principio pedagógico de la Institución diciendo que «no se conformaba con llevar la vida a la escuela; quiere llevar la escuela allí donde la vida se dé»; y añadía que, para valorarla, «hay que situarse en la época [...] y conocer el retraso en que vegetaba la enseñanza española. Solo así se apreciará el sentido revolucionario de su obra» (Llopis, 1955: 65).

Anteriormente se ha citado un artículo en el que Rodolfo Llopis describía las actividades que realizaba con sus alumnos fuera del aula, en el que podemos comprobar su clara apuesta por la metodología institucionista. Afirmaba allí que la única influencia eficaz con los alumnos se consigue estando mucho tiempo fuera de la clase, charlando con ellos, realizando salidas, excursiones y viajes. Este principio pedagógico lo asumió la educación de la Segunda República, y un ejemplo de ello lo encontramos en la circular de la Dirección General de Primera Enseñanza de 12 de enero de 1932, en la que podemos leer: «El maestro utilizará todos los grandes valores educativos que encierra el ambiente geográfico. La fábrica, el taller, la granja, el mar, todo lo que constituya la fisonomía económica y espiritual de aquella zona ha de ser familiar al niño y a la escuela» (1).

Respecto a los exámenes y a la disciplina de los alumnos, podemos ver los principios de la Institución: «absoluta protesta, en cuanto a disciplina moral y vigilancia, contra el sistema corruptor de exámenes, de emulación de premios y castigos, de espionaje y de toda clase de garantías exteriores» (Llopis, 1935: 37-38). Para ser discípulo de la ILE el alumno debía aceptar su proyecto educativo y desear ser educado. El único premio era realizar bien la tarea educativa; el único castigo no realizarla, y por lo tanto, no mantener el nivel que la comunidad educativa exigía. Para evaluar los conocimientos adquiridos, Francisco Giner de los Ríos proponía utilizar el cuaderno del alumno donde se anotaba el trabajo realizado a lo largo de la escolaridad y comprobar así los progresos alcanzados. La supresión de exámenes junto con la eliminación de toda fórmula externa de disciplina eran dos de los aspectos originales de la Institución. La idea del cuaderno que proponía Francisco Giner de los Ríos aparece en un artículo de Rodolfo Llopis: «El Diario de clase». Para él, el Diario era «un fuerte motivo de honda colaboración entre profesores y alumnos. Es una manera 
de incorporarlos a las inquietudes de la clase» (1924: 8). Los alumnos tenían que valorar y calificar el trabajo de sus compañeros, como manifestación de su llamamiento constante al sentimiento de la responsabilidad.

La coeducación era otro principio esencial del régimen escolar de la Institución, ya que no había razón para prohibir en la escuela lo que de forma natural se daba en la sociedad. Se consideraba como uno de los «resortes fundamentales para la formación del carácter moral y la pureza de costumbres»; además, «es el más poderoso para terminar con la situación actual de inferioridad de la mujer, inferioridad que no empezará a desaparecer hasta que aquella se eduque, en cuanto a la cultura general, no solo "como", sino "con" el hombre» (Llopis, 1935: 38). La implantación de la coeducación generó en la sociedad española una gran polémica. Desde el Ministerio de Instrucción Pública se propuso una implantación progresiva. El 28 de agosto de 1931 se estableció la enseñanza mixta en dos Institutos de enseñanza media en Madrid y en Barcelona. En septiembre se estableció la coeducación en las Escuelas Normales, y el 17 de abril de 1932 en las escuelas anejas de las Normales ${ }^{3}$. Sabemos que Rodolfo Llopis estaba de acuerdo con la coeducación, y así lo expresó: «Razones pedagógicas, sociales y políticas aconsejan establecerla. Y se ha establecido sin dificultad ni tropiezo alguno. A pesar de las campañas de la prensa reaccionaria» (1935: 38).

Se utilizó la metodología activa de Johann Heinrich Pestalozzi y Friedrich Froebel, que la Institución aplicó a todos los grados. En todos ellos cabía «la intuición, trabajo personal y creador, procedimiento socrático, método heurístico, animadores y gratos estímulos, individualidad de la acción educadora en el orden intelectual como en todos» (Programa de la ILE, 1934: 12). Rodolfo Llopis suscribía los principios pedagógicos de la Institución; así lo manifestó en repetidas ocasiones: en la circular de la Dirección General de Primera Enseñanza de 12 de enero de 1932; también durante su actividad docente en la Escuela Normal de Cuenca, y, por último, al conocer la Escuela Nueva y el método de Ovide Decroly durante el curso escolar en que estuvo en Suiza, Bélgica y Francia para ampliar su formación.

Según establecía el Programa, en la Institución no existía separación entre la escuela de párvulos, la primaria y la secundaria: «los tres periodos

3. La enseñanza mixta en los Institutos se implantó por Decreto de 28 de agosto de 1931 (Gaceta del 29); en las Escuelas Normales, por Decreto de 29 de septiembre de 1931 (Gaceta del 30); en las Escuelas Anejas de las Normales, por Orden de 17 de abril de 1932. 
constituyen uno solo y continuo: el de la educación general». El alumnado estaba dividido en secciones, según el grado de desarrollo, y todos debían aprender las mismas disciplinas en las primeras secciones que en las últimas, siempre de acuerdo con su nivel madurativo. Las lenguas clásicas eran las únicas materias que la Institución creía que no debían imponerse a todos los niños, sino solo a aquellos que mostrasen un especial interés. Estudiaban desde el primer grado todas las materias que constituían la base de la cultura general de la época: «la lengua materna y las vivas, las ciencias naturales, matemáticas, física, química, sociales, filosofía, la historia de la civilización, la geografía, la literatura, la teoría y la historia del arte, el dibujo y el modelado, la música y el canto, el trabajo manual...». Rodolfo Llopis defendió ante la Cámara el mismo planteamiento de la ILE para la organización de las diferentes etapas del sistema educativo. Y, en la citada defensa de la enmienda socialista al artículo 48 de la Constitución, dijo: «Hay que conseguir que, desde la escuela maternal hasta la Universidad, todas las instituciones que existan en el país [...] estén todas ellas íntimamente coordenadas y enlazadas, como si fuesen los eslabones de una misma cadena» (20 de octubre de 1931).

La Institución deseaba que sus alumnos pudieran utilizar pronto y ampliamente los libros como fuente capital de cultura, pero no empleaba los libros de texto, ni se recurría a la memorización de las lecciones. Pensaba que todo ello contribuía a mecanizar el trabajo de clase. Proponía como funciones del maestro las de despertar y mantener vivo el interés del niño, excitar su pensamiento, sugerirle cuestiones y nuevos puntos de vista, enseñarle a razonar con rigor y a resumir con claridad y precisión los resultados. Para desarrollar la memoria y enriquecerla, se seleccionaba fragmentos de textos literarios que los niños aprendían. En la citada circular enviada por Rodolfo Llopis a los centros, una vez aprobada la Constitución, leemos: «La escuela libresca de ayer ha de ser superada por la escuela activa de hoy. Los horarios viejos y los programas rutinarios han de ser superados por los centros vivos de interés y por la libre curiosidad del niño» (12 de enero de 1932). El decreto de 7 de agosto de 1931 ordenaba la creación de bibliotecas en todas las escuelas públicas. El Patronato de Misiones Pedagógicas era el encargado de la adquisición, selección y distribución de los libros. El fondo de las bibliotecas quedó integrado por obras destinadas tanto para el disfrute de los niños como de los adultos, a los que también iban dirigidas (Patronato de Misiones Pedagógicas, 1933: 64). Esta medida tomada por el Ministerio de Instrucción Pública demostraba, una vez más, el deseo de culturizar a la población. 
La Institución consideraba indispensable la activa colaboración de las familias para que su obra fuera eficaz. El niño debía vivir en familia y a ella debía volver todos los días, cuando finalizara la escuela. Esta era para el niño lo que la esfera profesional y las complejas relaciones sociales para el hombre adulto, y en ninguno de ambos casos había motivo para que se suprimiera la vida familiar, pues nada entendían tan nocivo para la educación del niño como el manifiesto o latente desacuerdo entre su familia y la escuela. "Nada, por el contrario, tan favorable como el natural y recíproco influjo de una en otra» (Programa de la ILE, 1934: 18). Para Antonio Jiménez-Landi la Institución no solo se adelantó a la Escuela Nueva, sino que la superó, ya que mientras esta impuso el internado, en la Institución se defendía que el niño debía vivir en familia completando la acción educativa de la escuela en el hogar. Es importante destacar la convivencia que establecieron maestros y discípulos, la cual se prolongaba en las excursiones y en las colonias de verano (1976: 48-54). En cuanto a la relación familia-escuela, a Rodolfo Llopis le preocupaba el absentismo escolar que se daba en España en 1931. Por ello, ante las Cortes habló de la necesidad de dar «subsidios familiares» para que los niños no dejaran de asistir a la escuela y ayudar económicamente a sus padres. Él sabía que la escuela era la que debía acercarse a las familias: «la escuela establecerá esa relación íntima con la vida del trabajo y con la vida del hogar, donde tanta influencia puede ejercer. La escuela procurará interesar a los padres y a las madres organizando enseñanzas que respondan a sus inquietudes, organizando bibliotecas, lecturas, audiciones y conferencias» (Circular, 12 de enero de 1932).

La política educativa del Ministerio de Instrucción Pública asumió la mayoría de los principios educativos de la ILE, y a ello hizo referencia Rodolfo Llopis cuando escribió que la República no olvidó la deuda que tenía con Francisco Giner de los Ríos. Según Llopis, si la República había sido posible era gracias a la madurez política y a la conciencia cívica del pueblo español. A ello llegaron los españoles gracias a dos influencias: una intelectual y otra obrera. La primera se debía directamente a Francisco Giner de los Ríos; la segunda, a Pablo Iglesias. Aquel supo despertar y crear un ideal para la vida; este, además, supo despertar la necesidad de ofrecer la vida al servicio del ideal: «La República, agradecida a estos dos hombres, al votarse la Constitución, regaló la construcción de dos magníficos grupos escolares: uno, a la ciudad de Ronda, cuna de Giner de los Ríos; otro, a la ciudad de El Ferrol, cuna de Pablo Iglesias. A mí me cupo el honor de redactar el decreto-ofrenda» (Llopis, 1955: 67). Al instalarse 
en el despacho de la Dirección General de Primera Enseñanza, había colocado en el sitio de honor un retrato de Pablo Iglesias, y a su lado los de don Francisco Giner de los Ríos y don Manuel Bartolomé Cossío. Llopis se complacía en explicar a las visitas que entraban en el despacho y miraban los retratos con mal disimulada sorpresa lo que significaba aquel modesto homenaje que rendía «a los tres grandes educadores que tanto habían contribuido a forjar la conciencia revolucionaria del país» (1933: 21).

Con motivo del cincuentenario de la ILE, Llopis escribió un artículo en La Lucha donde afirmaba: «La Institución ha producido una intensa renovación espiritual en todos los órdenes de la vida nacional» (1926: 1). Decía que el día que se pudiera hacer inventario de todo lo que la Institución y Francisco Giner de los Ríos habían dado a España, los españoles se asombrarían, pues ambos acogieron a cuantos se les acercaron, desde el maestro de escuela al político encumbrado que planteaba altos problemas de Estado.

Sin duda, la República se encontró con muchos docentes formados en los principios pedagógicos de la Institución, pero también con otros que, conocedores de sus preceptos, los asumieron por propia iniciativa y pusieron en práctica en sus aulas. Efectivamente la Institución había ejercido una gran influencia en la educación española, y esta continuó intensificándose durante los primeros años de la República. Los que vivían en provincias podían comprobar que, cuando llegaba «un profesor o un maestro liberal, con ideas claras acerca de los problemas vitales, y con suficiente decisión espiritual para no humillar su conciencia de hombre», el comentario habitual era: «Ese es de la Institución...», aunque nunca hubiera tenido contacto con ella ni con sus hombres. Y es que, «como en el ambiente español flota la influencia "institucionista", no tiene nada de particular que hasta él "arribara la inteligencia amorosa" » (Llopis, 1926: 1).

\section{Bibliografía citada}

Cossío, M. B., De su jornada, Madrid, Aguilar, 1966.

Ferrer C. Maura, S., La Escuela de Estudios Superiores del Magisterio (1909-1932), Madrid, Cedesa, 1973.

HERAS J. DE LAS, «Rodolfo Llopis, añoranza de Cuenca», Elbanzo [Cuenca], 6 (1976).

JiMÉNEZ-LANDI, A., «La ILE en sus coordinadas pedagógicas», Revista de Educación, 243 (1976), pp. 48-54. 
LLOPIS, R., «El Diario de clase», Revista de Escuelas Normales [Guadalajara], 11 (1924).

— «Este es un libro de paz», La Lucha [Cuenca], 14 de noviembre de 1926.

- «Nuestros maestros: a Zulueta», Revista Escuelas Normales (enero de 1928).

- Circular de la Dirección General de Primera Enseñanza, 13 de mayo de 1931.

- Discurso pronunciado para la defensa de una enmienda al artículo 48 de la Constitución, 20 de octubre de 1931.

- Circular de la Dirección General de Primera Enseñanza, 12 de enero de 1932.

- La revolución en la escuela, Madrid, Aguilar, 1933.

— «El señor Cossío: una vida luminosa que se apaga», Leviatán, 17 (1935).

- «Nuestro don Fernando en Instrucción Pública», Le Socialiste [Toulouse], 9 de junio de 1949.

- «Francisco Giner de los Ríos y la reforma del hombre», Cuadernos del Congreso por la Libertad de la Cultura [París], 4 de marzo de 1955, pp. 60-67.

MoratinOS IGLESIAS, J., El pensamiento pedagógico del alicantino Rodolfo Tomás y Samper, Alicante, Ayala, 1988.

Patronato de Misiones Pedagógicas, Madrid, Ministerio de Instrucción Pública y Bellas Artes, 1933.

Programa de la Institución Libre de Enseñanza, Madrid, 1934.

Rodríguez Esteban, J. A., «La Geografía en la Escuela Superior de Magisterio (1909-1932)», Ería, 42 (1997), pp. 89-106.

Vilà Valentí, J., El conocimiento geográfico de España, Madrid, Síntesis, 1989.

Fecha de recepción: 24-7-2015

Fecha de aceptación: 8-12-2015 


\section{RESEÑAS}

Gerardo Diego, Prosa musical, I: Historia y crítica musical, edición de Ramón Sánchez Ochoa, documentación de Elena Diego Martín, Valencia, Pre-Textos / Fundación Gerardo Diego, 2014.

ELISA PRIETO CONCA

C. P. M. Antonio Lorenzo, Motril

En unas «Palabras preliminares» a este volumen que reúne los textos de historia y crítica musical de Gerardo Diego (Santander, 1896-Madrid, 1987), sus hijas Isabel y Elena hacen un recorrido somero por la aventura editorial de la escritura de su padre a partir de su fallecimiento. El poeta había dedicado sus últimos años a ordenar sus escritos con vistas a la publicación, pero no consiguió ver editada su poesía, pese a que el corpus estaba ya entregado a la editorial que iba a encargarse de ello. Si eso ocurría con la poesía, la situación de la prosa era manifiestamente peor, pues casi todos sus escritos habían ido apareciendo en publicaciones periódicas, no pocas veces volanderas, a lo largo de varias décadas, y algunos permanecían inéditos. La poesía reunida pudo salir en 1989 en Aguilar, adonde la llevó Jaime Salinas, en edición de F. J. Díez de Revenga; pero el proyecto de hacer lo propio con la prosa hizo agua. Las poesías se reeditaron en Alfaguara, en el centenario del nacimiento (1996); en esta ocasión en tres tomos, y no en dos como en 1989. En esa misma editorial comenzaron a publicarse sus prosas, de las que aparecieron cinco volúmenes, a cargo los dos primeros del citado Díez de Revenga (1997) y los otros tres de José Luis Bernal (2000). Como tantas veces sucede con los buenos propósitos, el de publicar todas sus prosas no pudo completarse, y de esas cinco entregas prosísticas quedaron excluidos los textos que se recogen 
ahora, al amparo de la Fundación Gerardo Diego, y especialmente de su animosa directora gerente Pureza Canelo.

Quien no esté al tanto, quizá pueda pensar que Gerardo Diego se ocupó ocasionalmente de la música como correspondería a quien, por seguir su modesta autocaracterización, solo era un «entusiasta apasionado»o un «amador deleitante» de la música, pero no exactamente un músico o un musicólogo de oficio. Es cierto, y el preparador de esta edición, Ramón Sánchez Ochoa, se ocupa de aclararlo, que la formación musical de Diego había discurrido «de manera autodidacta, sin conservatorios, calendarios de exámenes ni programas académicos» (p. 15), lo que quiere decir que no responde a la figura de un músico profesional; pero también lo es que esa formación se prolongó a lo largo de toda su vida, que fue un asiduo practicante del piano, que tuvo una gran familiaridad con las salas de concierto, y que ofreció numerosas conferencias, muy propias del hibridismo artístico de esa generación «del 27» que él presentó al público en su recopilación de 1932 (Poesía española. Antología 1915-1931), en que las palabras iban acompañadas de la ejecución pianística, y las notas y los versos formaban un frente unitario. En suma, la música fue en Gerardo Diego una dedicación constante, y un tema sobre el que pensó mucho y escribió también mucho, por lo común con gran fundamento.

El presente volumen, primera entrega de los dos en que terminará cuajando el proyecto (el segundo dedicado a cuestiones de estética musical; confiemos en que ahora nada se interponga), resulta un utensilio principal, y no solo subsidiario o complementario, para el conocimiento abarcador de Gerardo Diego. Pero, aparte del interés intrínseco que tiene para iluminar al escritor, es también interesantísimo para efectuar el seguimiento de la vida musical española del siglo xx, y comprobar la filtración de la música de cualquier época a través de la sensibilidad de uno de los principales teóricos de la poesía de ese mismo siglo. Echar la vista al índice onomástico con que se cierra el libro, y que contiene un millar muy largo de entradas, permite ver casi de un fogonazo el campo de sus intereses, la apertura de sus criterios, así como las recurrencias y obsesiones musicales del poeta caracterizado por la curiosidad creativa respecto a otras artes. Sobre la acotación de sus campos de interés, lo mejor es oír a Sánchez Ochoa, quien especifica, de norte a sur, algunos hitos que manifiestan la amplitud de esos campos: «desde las cantigas de Alfonso X el Sabio a las últimas obras de Bruno Maderna, pasando por la polifonía renacentista, los conciertos de Bach, las sonatas para violín y piano de Beethoven, los nocturnos de Chopin, los Lieder de Schubert, los preludios de Debussy, 
los ballets mitológicos de Dallapiccola o las piezas religiosas de Messiaen» (p. 17). Basta para formarse una idea de la versatilidad estética de Gerardo Diego, cuyo carácter jánico él mismo confesó cuando se refirió a la atracción que sentía, al mismo tiempo y sin necesidad de tener que elegir, por las enseñanzas clasicistas de la tradición noble y por la fiebre vanguardista (lo que se tradujo, por ejemplo, en libros poéticos tan opuestos como Imagen, de 1922, y Versos humanos, de 1925).

Ha estado al cuidado de esta recopilación Ramón Sánchez Ochoa, profesor del Conservatorio Superior de Música de Valencia y especialista en las relaciones entre música y literatura en el ámbito del 27, lo que, al margen de esta reunión de textos ajenos, ha fructificado en Poesía de lo imposible: Gerardo Diego y la música de su tiempo (2014), premio «Gerardo Diego» de investigación literaria, donde el santanderino actúa como hilo que recorre algunos de los episodios musicales más interesantes de la época, dentro del marco dominantemente franco-español: Fauré, Debussy, Ravel, Falla, Esplá. Su conocimiento le permite tramar un recorrido suficiente, en el que la erudición no oculta las líneas básicas de la exposición, a través de los escritos de Diego en un «Prólogo» ajustado y esclarecedor, donde se nos ofrece toda la información sobre el contenido del volumen, que carece de notas aclaratorias. Por esas páginas prologales sabemos de las relaciones de Gerardo Diego con la música, en escritos que arrancan en los años veinte y alcanzan hasta los ochenta. Y por ellas también sabemos que hay dos núcleos que ordenan estos escritos como una entidad de relativa organicidad, a pesar de su amplitud temática y cronológica: el del romanticismo musical —Schubert, Schumann, Chopin- por un lado, y, por otro, el de los músicos con algún grado de coetaneidad (los que estudia en el libro antes citado y otros como Albéniz, Guridi, Mompou, Rodrigo o los hermanos Ernesto y Rodolfo Halffter). Sobre los polos de gravitación de sus intereses estéticos en relación con la música, cabe subrayar lo mismo que él confesó a propósito de su poesía: la síntesis entre clasicidad y vanguardia, como corresponde a una personalidad difluente que, en palabras de Sánchez Ochoa solidarias con lo apuntado, se siente «atraída a la vez por el pasado y el presente, lo clásico y lo romántico, la modernidad y la tradición» (p. 18).

Los escritos musicales de Gerardo Diego suelen estar suscitados por cualquier episodio cultural relativo a un recordatorio, una muerte, un aniversario, la publicación o la lectura de un libro... Otras veces responden a la tradicional reseña de un concierto, como sería propio del periodista cultural que, en rigor, no era, pero cuyas tareas realizó con puntual dedicación. 
También hay reflexiones estéticas de más largo aliento que las reseñas o «crónicas» musicales, y son, como cabía esperar, muy abundantes y de gran interés los escritos en que trata las conexiones entre las dos artes discursivas, música y poesía, y singularmente cuando estas reflexiones están ceñidas a los creadores de su generación o inmediatamente antecedentes. Los textos fueron apareciendo en periódicos diversos ( $A B C$, Arriba, La Nación, La Tarde...), revistas culturales y literarias (Escorial, Ínsula, Proel, Cuadernos Hispanoamericanos...), eso cuando no constituyeron programas de conciertos o fueron soporte mecanográfico de conferencias, programas radiofónicos, etc., que han permanecido dormidos en los archivos que hoy custodia su Fundación.

No se pueden compendiar, ni siquiera muy extractadamente, las características de estas prosas «musicales»; pero por aquí y por allá nos encontramos con una información extensa, una sensibilidad musical que es lo único que cabía presuponerle, y una agudeza valorativa sorprendente. Por poner solo un ejemplo, en la lectura que hace de la Pequeña crónica de Ana Magdalena Bach, de la que da cuenta en $A B C$ (10 de mayo de 1946), traza una deliciosa semblanza de la segunda esposa del "Gran Cantor», expone finamente las razones de esa hermosa superchería literaria en la que muchos musicólogos cayeron como incautos, y termina estableciendo la belleza - y la dificultad - de aquellos cuadernos para uso de la esposadiscípula en que los rizos de la forma y los complejos constructos polifónicos se resuelven en ligerezas para niños. A ese propósito, se dirige Diego a los «fantasiosos hércules de feria, que se lanzan a edificar sus complicadas torres de babel musicales», y les emplaza a la difícil facilidad de hacer algo parecido a lo del maestro que se agacha para estar a la altura de los discípulos sin que se le note el esfuerzo: «Muy bien, todo eso está muy bien - les diría - Magnífico tanto delirio de grandeza y tanta apoyatura maraña. Ahora, hágame el favor de llenarme estos veinticuatro compases con una invención a dos voces, con una gavotita para manos de una extensión máxima de quinta, que quiero regalársela a mi niña para el día de su santo» (p. 65). Observaciones parecidas, así como expresiones de su amor a ciertos compositores — «el prodigioso músico para niños Béla Bartók, cuya muerte llora todavía el musical universo» (p. 66)—, son muestra de que Gerardo Diego no era sin más un cronista de sociedad aplicado a la música; sino alguien que captó con sutileza sensitiva los valores de la música occidental, y en particular la de su tiempo histórico. Y aunque en sus ponderaciones prima la comprensión elogiosa, tiene también sus recelos y hasta sus manías explícitas, según corresponde a quien actúa como 
crítico que despliega su particular poética, con la que el lector puede o no estar de acuerdo. A ello se refiere Sánchez Ochoa cuando habla de su ojeriza al «sinfonismo de Rachmaninov, la "peste del chaikovskismo", los "futbolísticos" conciertos para piano de Prokofiev o el "centroeuropeísmo feísta" de algunos contemporáneos» (p. 18).

Habría sido de agradecer que el editor, además de precisar los criterios generales de la transcripción de los textos en la sucinta «Nota a la edición» (pp. 25-26), hubiera explicitado los de su disposición estructural en el volumen, que en todo caso puede seguirse con alguna dificultad si se atiende cuidadosamente al índice. El procedimiento usado no ha sido el cronológico de la escritura o publicación, que hubiera privilegiado una contemplación diacrónica de su sensibilidad y progreso musicales (claro que en detrimento del orden sucesivo de los autores, tal como corresponde a una «historia» de la música), sino el de la compartimentación de los materiales en tres secciones por razón del tema: compositores y sus obras (grupo primero), intérpretes (grupo segundo), crónicas musicales (grupo tercero). La sección principal es la de los compositores, y permite efectuar un recorrido por la música en su secuencia histórica, desde las cantigas alfonsinas hasta Gerardo Gombau; lo cual implica yuxtaponer trabajos de distinta envergadura — según el soporte para el que iban destinados-y de fechas de escritura muy alejadas entre sí.

Todo ello es opinable, pero no resulta sustancial. Lo verdaderamente importante es el rescate de estos materiales, que darán luz a la estética de Gerardo Diego y, también, a la música y los músicos de cualquier época, pero sobre todo de la contemporaneidad, tal como fueron absorbidos y apreciados por uno de los tratadistas estéticos, además de poeta, más conspicuos de su tiempo. 

Rafael Alarcón, Vértice de llama: El Greco en la literatura hispánica (Estudio y antología poética), Valladolid, Universidad de Valladolid, 2014.

CARMEn Alemany Bay

Universidad de Alicante

En el 2014 se celebró el IV Centenario del fallecimiento del Greco, y este evento se saldó, entre muchas otras cosas, con la publicación de un libro - estudio y antología - sobre aquel pintor griego que recorrió tierras italianas, vino a España para trabajar en el Escorial y vivió sus días finales en Toledo. Pero el Greco, en el planteamiento de este volumen escrito por Rafael Alarcón Sierra, es visto desde una óptica peculiar: como figura ligada a la literatura en lengua española; y es este uno de los muchos méritos que contiene Vértice de llama: El Greco en la literatura hispánica (Estudio y antología poética).

Para analizar y reseñar este amplio recorrido de la figura del Greco por los caminos de la literatura, fundamentalmente de la poesía escrita en español, sigamos el orden que nos impone la hermosa portada del libro. Empecemos a hablar sobre el autor de este sólido trabajo, Rafael Alarcón Sierra. Profesor de la Universidad de Jaén, realizó sus estudios universitarios en la de Zaragoza, y tempranamente destacó por sus análisis de Manuel Machado; es fundamental su ensayo Entre el modernismo y la modernidad: la poesía de Manuel Machado (1999). Machado (Manuel) fue la piedra de toque de su investigación; a partir de ahí, este crítico indagaría en autores que están, temporalmente hablando, en la órbita del andaluz, como Rubén Darío, Miguel de Unamuno, Ramiro de Maeztu, Azorín, Juan Ramón Jiménez, junto a algunos escritores posteriores como Federico García Lorca o, más tardío, Luis Felipe Vivanco. Todo un camino preparatorio hasta la publicación del libro que nos ocupa, en el que se intuyen tantos sólidos conocimientos. 
Respecto al título, su primera parte, "Vértice de llama», procede de uno de los versos que Rafael Alberti dedicó al Greco: «Aquí, el barro ascendiendo a vértice de llama», perteneciente al poema «El Greco», que lógicamente se incluye en la amplia antología poética que nos ofrece Alarcón Sierra en el cierre del volumen. Las siguientes palabras del título son la descripción de lo que el lector visualizará en el índice y se completará con la lectura de este libro en el que se combinan lo histórico y lo crítico, y se establece una pauta, tan presente hoy en día en lo poético, como es el diálogo de la pintura con la poesía, pero también con otras artes de la imagen.

Las palabras de Alarcón Sierra no pueden ser más explícitas e impactantes desde la «Introducción»: el Greco «es nuestro contemporáneo. Es un fecundo anacronismo moderno» (p. 9). Con esta certeza, y con la convicción de que el cretense ha sido inspiración y guía para la modernidad, pero sobre todo para esa modernidad más radical que comenzó con las vanguardias, nuestro crítico comienza la aventura, a través de un riguroso y detallado estudio, de la presencia constante y fructífera de este pintor en las letras hispánicas; sin olvidar, como también señala en las primeras páginas, que el Greco es también, y ya tirando del mito, «una creación de la primera mitad del siglo XX» (p. 9). Si bien la originalidad del cretense ya fue descubierta por anteriores pintores, Doménikos Theotokópoulos, en palabras de Alarcón Sierra, «es visto como un precedente de simbolistas, modernistas, cubistas, futuristas o expresionistas» (p. 9); es decir, autores de movimientos artísticos de los que Alarcón Sierra es un gran conocedor. Por eso no es de extrañar que, en las páginas de este libro, encontremos tanta información, tantos detalles y pormenores que solo podían venir de la sutileza de la que siempre ha hecho gala en sus investigaciones este profesor e investigador de la Universidad de Jaén.

Tras la puesta en escena, que es la precisa «Introducción», el libro se despliega en tres grandes bloques para conseguir a pie juntillas lo que se nos propuso en el título. El primero, titulado «La construcción del Greco en la modernidad», es un exhaustivo recorrido, siempre ágil, en el que se cuenta la evolución de ese que ya podemos llamar "personaje», desde el siglo XVII hasta las últimas décadas. En estas páginas, no más allá de las setenta, el lector irá intuyendo, a través de los argumentos de Alarcón Sierra, cómo se ha ido modulando y transformando la figura del Greco y cómo se ha ido asumiendo a través del tiempo su legado pictórico desde las letras. También sabremos que Azorín y Pío Baroja lo mencionan en algunas de sus novelas; o que Ortega y Gasset y Eugenio D'Ors le dedicaron 
ensayos; y que también escribieron sobre él Ramón Gómez de la Serna o Gregorio Marañón. Este primer apartado es un sorprendente compendio de información sobre literatura y arte, amén de otras disciplinas.

En la segunda parte, «El Greco en la poesía hispánica», nuestro crítico organiza, en casi un centenar de páginas, un catálogo en el que con minuciosidad se explica cómo los poetas han ido construyendo versos de los que el pintor cretense y su obra se han hecho partícipes. En cada uno de los autores enunciados — casi un centenar- se detalla, a modo de muestra, cuál es su pequeña o gran aportación; podemos citar a modo de ejemplo a Francisco Villaespesa, a Manuel Machado, a Oliverio Girondo, a Gastón Baquero, a Miguel Hernández, o a poetas más recientes como Blanca Andreu o Jorge de Arco. Del poeta de Orihuela dirá que «es quizá Miguel Hernández quien da el pistoletazo de salida en el soneto titulado "En toda su hermosura", último de los tres dedicados "A María Santísima" "(110), pues fue el primer autor del xx que se refiere al Greco en un poema de contenido religioso; pero también se menciona a poetas relevantes de geografías no hispánicas, como William Carlos Williams, «quien en su metapoético "Deep Religious Faith", incluido en uno de sus mejores libros, The Desert Music (1954), lo cita como primer ejemplo de la necesidad vital de la poesía y el arte» (p. 124).

Tras los rigurosos estudios comprendidos en la primera y segunda parte de Vértice de llama: El Greco en la literatura hispánica, el volumen se cierra con «El Greco en la poesía hispánica (Antología)». Huelga decir que es la antología más amplia sobre el Greco en la poesía hispánica, pero conviene explicitar que hasta los más avezados en conocimientos de poesía quedarán sorprendidos - a pesar de que ya han tenido noticia de ello en el capítulo anterior- de cuántos poetas de nuestra cultura han tenido en mente a ese «anacronismo moderno». La lectura de esta antología posibilita al lector comprobar cómo se ha ido configurando desde lo poético la pintura y la figura del Greco a través de los siglos, fundamentalmente en el xx, en el que fue enaltecido como icono; pero también cómo cada poeta asimila a su manera el legado del cretense, acercándolo a su propia visión del arte y aportando su propia sugestión en los versos. O bien -esta sería una nueva cala - realizar un original paseo por la poesía escrita en español, desde los textos poéticos más antiguos incluidos, los de Paravicino y Góngora, hasta los más recientes; sin olvidar aquellos poetas que dieron brillo a nuestra cultura como Alberti, Guillén o León Felipe.

La obra que aquí nos ocupa es en gran parte el corolario de una investigación sostenida a lo largo del tiempo de quien es poseedor de una vasta 
trayectoria en el campo del hispanismo, específicamente de la poesía, pero también profundo conocedor de otras artes, como es el caso de Rafael Alarcón Sierra. Las páginas de este libro enseñan, a través de un lenguaje sugestivo, pasajes sugerentes en los que nuestro crítico nos ofrece la imagen de uno de los pintores más originales y controvertidos de la historia de la pintura. He aquí, en fin, una investigación exhaustiva, realizada con agudeza y no exenta de originalidad por el tema del que se ocupa. 
Carmen Rivas Máximus, La literatura brasileña en España: recepción, contexto cultural y traductografía, Salamanca, Ediciones Universidad de Salamanca, 2014.

DAVIDE MOMBELLI

Universidad de Alicante

La traductografía, pese a haber experimentado en las últimas décadas un incremento bibliográfico y científico considerable, sigue siendo la gran ausente en las más difundidas historias de la literatura española. En muy pocas ocasiones se dedican páginas a la difusión de un determinado libro o autor extranjero en el país, lo que atañe incluso a las personalidades literarias más importantes. En efecto, el traductor ha sido desde siempre un instrumento indispensable, pero al fin y al cabo un mero instrumento, y su reconocimiento académico escaso: solo aparece en letras minúsculas en la portada, y a veces ni siquiera se explicita, y queda relegado entre los datos técnicos de la publicación, respondiendo a una simple obligación de naturaleza burocrática. Así, el interesado en cuestiones de interrelaciones culturales tiene que buscar información y datos en estudios dispersos, que intentan suplir esta carencia. Es el caso del libro de Carmen Rivas Máximus La literatura brasileña en España: recepción, contexto cultural y traductografía. La autora de esta monografía presenta un exhaustivo y documentado panorama de las letras brasileñas en España, elaborando un análisis indispensable para determinar la difusión y la importancia de la influencia en nuestro país de la literatura americana en lengua portuguesa, a través de una rigurosa y completa taxonomía, el examen estricto, el comentario selectivo y la plena reconstrucción del objeto de investigación propuesto.

La metodología empleada es, inevitablemente, comparatista. La aparente proximidad del idioma español y portugués puede albergar razones de mucha lejanía, y así lo cree Rivas Máximus. Superando el escollo de 
los «falsos amigos», que interesa otras relaciones de proximidad lingüístico-cultural como es el caso hispano-italiano (esa proximidad que aleja indiscriminadamente por principio la virtualidad más fulgurante de toda relación en los estudios comparatistas), el presente volumen se configura como el primer gran estado de la cuestión hispano-brasileña, así como el mejor instrumento determinable para el conocimiento general y el estudio de la literatura brasileña en España.

Hay que precisar que el término «literatura» es aquí entendido en su sentido más amplio, casi ilustrado, incluyendo no solo la obra literaria poética y de ficción, sino también el ensayo y los escritos de carácter más específicamente científico. Así, la autora divide su investigación en dos grandes secciones, una primera dedicada a los «géneros literarios artísticos» y otra centrada en los "géneros literarios ensayísticos».

El modus operandi adoptado en las dos partes es el mismo: Rivas Máximus tiene en cuenta el establecimiento de un determinado autor en España, su primera obra publicada, si la traducción es directa o no, y, a continuación, además de una breve e indispensable anotación biobibliográfica de los autores a pie de página, se explicita también la indicación de sus obras publicadas en el país. Finalmente, se proponen ciertos ejemplos contrastivos de traducción. Dado el carácter informativo-erudito del estudio, el estilo muestra un cierto esquematismo discursivo y la iteración de construcciones sintácticas que incurren en el formulismo. Pero ello se complementa con la claridad de la exposición y la facilidad de consulta (porque el libro es, esencialmente, una obra de consulta).

La literatura brasileña en España se abre con un capítulo de «Introducción general», en el que se delinean las características principales de la investigación y se configuran los objetivos de esta. Es destacable el apartado dedicado a «Las instituciones culturales brasileñas en España», donde se subraya la importancia que tuvo la Revista de Cultura Brasileña en la difusión de la literatura y el arte brasileños en España, máxime porque en sus páginas se editan versiones de poesía y relatos, a cargo de ilustres traductores como Cansinos-Assens, Ángel Crespo o Dámaso Alonso, para citar a los más cimeros. Cierra el capítulo introductorio una sección titulada «Sobre traducción y traductores»: allí se ofrece la nómina esencial de los traductores y se comentan brevemente algunos rasgos definitorios de su concepción y praxis de la traducción. Esclarecedores son los comentarios sobre Ángel Crespo o Basilio Losada, por ejemplo, en los que se repasan también nociones básicas de teoría traductológica. 
Una aclaración, fundamental para el entendimiento de las relaciones Brasil-España: la casi totalidad de textos brasileños hasta ahora publicados en España son traducciones recientes y, con mucha frecuencia, solo editadas a partir de los años sesenta del siglo Xx. Verdadero hito es la traducción, fechada en 1967, de la novela de Guimarães Rosa Gran Sertón: Veredas, primera novela brasileña traducida en España.

La segunda parte del libro recoge un detallado análisis de los «Géneros literarios artísticos», divididos en tres secciones: «Géneros poéticos», «Géneros narrativos», «Géneros dramáticos». Cada apartado se cierra con un análisis contrastivo de las traducciones de algunos textos fundamentales, como, en el caso de la poesía, un poema de Gregorio de Matos (1633) y otro de Antonio de Castro Alves (1847).

Es interesante el apartado dedicado a las «leyendas», un género narrativo muy frecuentado en el ámbito literario y folclorista brasileño, sobre todo porque, como recuerda la autora, «en Brasil hay un factor nuevo y relevante en la formación del inconsciente nacional, el negro africano, que, al proceder de varias naciones, de varios grupos raciales, enriquece de una forma ilimitada el ya diversificado folklore brasileño revelando en el Brasil una Cuba mucho más completa y amplia» (p. 150).

En cuanto a la novela, Rivas Máximus hace hincapié en la importancia decisiva, para la difusión de la literatura brasileña fuera de las fronteras nacionales, de autores como Machado de Assis o João Guimarães Rosa. También, pese al ostracismo (justificado) de la crítica académica respecto a su obra, se analiza el "caso Coelho», un autor muy popular cuyas novelas y relatos son continuos best sellers en el mercado editorial español y no solo en él.

De los géneros dramáticos se ofrece un diagnóstico poco alentador. En el caso del teatro, ello se debe a que la dramaturgia brasileña fue un fenómeno literario tardío, en razón de lo difícil que se hace la geografía natural y social de la nación. Su presencia en España es muy escasa y poco relevante. El cine no corre mejor suerte: aunque no se conozca mucho, su presencia se traduce en pocas pero significativas proyecciones en los festivales de cine españoles. La temática privilegiada de los films que logran sobrepasar los confines americanos es principalmente social, comprometida.

Pasando a la tercera parte del estudio, los «Géneros literario ensayísticos», el autor más traducido es, sin duda, Paulo Freire y su obra pedagógica. Muy útil es la sección dedicada a los «Estudios lingüísticos y literarios», en la que se comentan sucintamente todas las historias de la 
literatura brasileña traducidas o realizadas en España. El primer libro es de 1958: José Osório de Oliveira, Historia breve de la literatura brasileña, que durante muchos años fue el volumen principal para los que deseaban acercarse a las letras americanas. El más reciente: una Guía de literatura brasileña, publicado en Salamanca en 2004 a cargo de María Josefa Postigo. Siguen varios apartados sobre cada uno de los ámbitos disciplinares científicos y artístico-técnicos: «Estética, arte y fotografía. Exposiciones, galerías», «Escritos musicológicos», «Antropología, Historia, Política, Sociedad y Economía», «Teología y estudios religiosos y filosóficos», «Cartas»y, finalmente, «Crónicas».

En «Conclusiones sobre traductografía» se resume la investigación, reiterando las interpretaciones que se han ido ofreciendo a lo largo de ella. La relación traductográfica entre España y Brasil, repetimos, es un fenómeno reciente, de la segunda mitad del siglo Xx, y ello se debe principalmente a la juventud de la literatura brasileña. Además, en los tiempos pasados no ha sido un apoyo que España y Portugal, matriz de la lengua de Brasil, hayan vivido de espaldas estando tan cerca.

Tras el repertorio de la literatura brasileña traducida en España y otras obras complementarias descritas en los precedentes capítulos, se incluye finalmente un interesante texto de Juan Andrés, el gran comparatista español autor de una historia de la literatura universal, sobre la palabra «Brasil».

La literatura brasileña en España se presenta como una obra de consulta fundamental para cualquier estudio de literatura brasileña desde España. Es un recorrido histórico que, a través del estudio de los libros traducidos, permite proyectar luz sobre más de cinco siglos de relaciones políticas, económicas y culturales, desde que, con el tratado de Tordesillas, las dos naciones colonizadoras más potentes se repartieron, mano a mano, el territorio y el futuro del continente americano, dando inicio a la aventura geográfica de estos dos idiomas internacionales. Quizás se eche en falta un estudio de esta recepción en los principales autores españoles, clarificando ejemplos y estableciendo paradigmas de comparación. Pero este no es el objetivo del presente volumen, cuya utilidad instrumental queda validada por el rigor y la globalidad de la investigación. Gracias a un estudio como el de Rivas Máximus se podrá hacer un análisis de la recepción y fortuna textual de estas obras, con el objetivo de comprobar si el «profundo sentimiento brasileño» que permea toda la literatura de ese país, en palabras de Jorge Amado, otro de los grandes adalides de la literatura brasileña, ha podido manifestarse en las letras hispánicas. 
Carmen Alemany Bay (coord.), Artes poéticas mexicanas. De los Contemporáneos a la actualidad, Guadalajara (México), Universidad de Guadalajara, 2015.

FERRAN RIESGO

Universidad de Alicante

Las artes poéticas son una de las formas generadas por la literatura clásica que mejor se han adaptado con el paso de los siglos, y probablemente una de las pocas que se siguen cultivando con naturalidad, aun cuando vistan hoy máscaras bien distintas a las de aquella fundamental Ad Pisones de Horacio. En México, una nación cuya lírica ha demostrado a la vez profundo arraigo en la tradición - aunque no siempre en la propia, como probó a menudo Octavio Paz-y una capacidad incombustible de ruptura e innovación, las artes poéticas han conocido una floración especialmente intensa en los últimos cien años. Tal diversidad invita y casi obliga a los poetas a situarse respecto a la propia escritura, y a considerar la escritura como proceso en sí. Al cabo, ya sea en taxativos programas líricos, ya en indagaciones de carácter más abstracto, las causas, fines y modos de esta poesía se han acabado estableciendo como uno de sus grandes temas; la crítica especializada, sin embargo, no se había fijado hasta ahora en este aspecto como en una posibilidad de interpretación global.

Artes poéticas mexicanas, volumen colectivo coordinado por la profesora Carmen Alemany, ofrece un panorama cabal de la abigarrada identidad poética de la literatura mexicana contemporánea; la novedad de la propuesta, y una de las virtudes del libro, consiste en hacerlo precisamente a través de las artes poéticas, ofreciendo al tiempo una visión clara de su evolución y de la evolución de la poesía misma a través de ellas. En palabras de Alemany, se trata de «una pequeña muestra de la puesta en escena de las prácticas poéticas que evidencian los procesos creativos y singulares 
de la poesía en México» (p. 52), que se caracterizaría, en fin, por estar «siempre en movimiento, en contraste y en evolución», y que «de forma constante y diversa se ha acercado a la reflexión de la propia poesía».

La obra presenta una estructura clara, sólida y bien trabada: una amplia introducción, a cargo de Alemany y titulada «Reflexión y análisis de las artes poéticas mexicanas desde los Contemporáneos hasta las últimas tendencias», precede a quince capítulos en que los estudiosos se acercan a las poéticas de diversos autores mexicanos; normalmente, uno por capítulo, aunque hay excepciones (el caso de Ruisánchez Serra, que cierra el libro). Los capítulos se disponen en el índice también por orden cronológico de los autores sobre los que versan, de tal modo que el subtítulo del libro (De los Contemporáneos a la actualidad) resulta muy adecuado: los poemas menos recientes proceden de la década de 1930, y, los más, del año 2014. Si en las «Palabras liminares» se menciona el deseo de no «agotar ni nombrar a todos los poetas de las distintas épocas o grupos», sí se nombra en los textos a todos los imprescindibles, e incluso a muchos que están camino de serlo.

La introducción es en esencia un completo artículo que ronda las cincuenta páginas, organizado como una historia de las artes poéticas en la lírica mexicana del siglo Xx. Las corrientes, generaciones y figuras más relevantes de la época quedan ubicadas en un amplio y ambicioso panorama, vertebrado por el devenir de las preceptivas y reflexiones que sobre la propia poesía han formulado - no siempre explícitamente- los poetas, sin dejar desatendidas puntuales derivas personales. La selección de ejemplos textuales y la claridad expositiva proyectan una imagen bien definida de los cambios en las poéticas nacionales y sus etapas, mientras se comienzan a perfilar los rasgos de los poetas que más adelante se tratarán en detalle. De este modo, la introducción funciona a guisa de casillero donde ubicar los estudios que le siguen, que el lector encontrará ya razonablemente ordenados y conectados. Así, si la poesía de los Contemporáneos «sustancialmente es una definición de lo estético en el lenguaje», y en sus poéticas se aprecia «cierto intelectualismo manierista» (p. 22), en la década siguiente las propuestas literarias de Octavio Paz y Efraín Huerta marcarían dos caminos casi antitéticos en poesía; algo más tarde, Alberto Quintero Álvarez llegaría para proponer una tercera vía. Tras exponer un completo mapa de las generaciones «del medio siglo» $\mathrm{y}$ «del 72», la introducción recorre el boom poético de los años 70 y la evidente diversificación lírica que presenciaron los 80 . 
Alemany titula el apartado final de la introducción «Últimas generaciones poéticas: las artes poéticas quedaron en otra parte», y concluye aquí que la poesía mexicana más reciente o actual se caracteriza por «el desconcierto, la confusión y cierto caos» (p. 46), y «aparece determinada por el fin de la historia, por la llamada muerte del sujeto, por la autorreferencia hasta límites insospechados, por la ruptura y por la trasgresión lingüística» (ibid.); es decir, que la poesía mexicana y su autorreflexión discurren ahora, aunque sin renunciar a su propio carácter, por el cauce ya mayoritario de lo posmoderno.

A grandes rasgos, los quince capítulos proponen un mosaico de temas, autores y perspectivas que no resulta nuevo en un volumen de este tipo, pero sí particularmente acertado en este caso, dado el objeto de estudio. Abre el índice Rosa García Gutiérrez, que dedica su estudio a Xavier Villaurrutia. Selena Millares expone la conjunción de clasicismo y vanguardia en la poesía de Jorge Cuesta, mientras Cecilia Eudave se ocupa de la búsqueda de la pureza poética en la obra de Gilberto Owen. La figura central que es Paz la trata Manuel Fuentes Vázquez, ofreciendo un acertado panorama de los múltiples esfuerzos pacianos por encontrar una verdad en poesía, y explicarla. Vicente Cervera se ocupa de la poesía de Rosario Castellanos, única mujer, junto con Maricela Guerrero, que ocupa un lugar de importancia en el índice. Eva Valero se centra, por su parte, en la poesía de Jaime Sabines, y Aníbal Salazar examina la particular poética — «sui géneris», escribe en el título— de Gabriel Zaid. Otros dos escritores de igual relevancia, como son José Emilio Pacheco y Homero Aridjis, son estudiados, respectivamente, por Francisca Noguerol y por Patrizia Spinato.

Ya en el terreno de los poetas más jóvenes, Ana Chouciño busca resaltar las principales claves en la poética de Francisco Hernández, mientras que Alejandro Piña rastrea las directrices líricas de una única obra de Alberto Blanco, Un año de bondad. Ignacio Ballester recoge y organiza los principios poéticos diseminados por la obra de Vicente Quirarte, mientras que Francisco Estrada habla, aportando una nota adicional de variedad, de la reflexión poética extralírica en los escritos de Julián Hebert. Clausura el índice el capítulo que José Ramón Ruisánchez dedica a Maricela Guerrero, y tangencialmente a otras poetas de su generación: un estudio de corte psicoanalítico que enlaza con la actualidad lírica mexicana más inmediata.

Artes poéticas mexicanas es, en definitiva, un recorrido histórico por el proceso mexicano de sublimación de las artes poéticas, «aquello que podríamos denominar la esencia de la poesía desde la misma poesía» 
(p. 10), de nuevo según Alemany. Responde con fidelidad a la diversidad de su objeto de estudio, y cumple con solvencia los propósitos que quedaban planteados en las «Palabras liminares»: logra dar cumplida cuenta de toda una época literaria, recuperar voces y voluntades poéticas de indudable valor, y lo hace desde perspectivas diversas y siempre sugerentes. La novedad de centrarse en el enfoque metapoético, esa iniciativa hasta ahora inédita en la crítica mexicanista - y casi con seguridad en la hispanoamericanista en general-, reactualiza el prestigio de la tradición y dota a la obra de empaque y frescura a partes iguales. La simetría estructural entre la introducción y la ordenación del resto de contenidos le confiere un equilibrio que facilita la lectura y refuerza su entidad global, mientras que su carácter ampliamente abarcador dota a la obra de una ambición atractiva para el lector, y genera expectativas que no quedan sin cumplir. Esta combinación de factores, junto con la calidad y variedad de las aportaciones de los participantes, permite afirmar que se trata no solo de un estudio bien construido y realizado, sino, además, de una propuesta crítica pertinente, novedosa y necesaria, además de la primera incursión en un terreno casi virgen que promete generosos descubrimientos. 
Alberto Santamaría, La vida me sienta mal: argumentos a favor del arte romántico previos a su triunfo, Salamanca, El Desvelo, 2015.

LUIS BAGUÉ QUÍLEZ

Universidad de Murcia

Alberto Santamaría (Torrelavega, 1976) ostenta la doble condición de poeta y crítico. Los caprichos editoriales han querido que sus dos últimas entregas compartan un hueco en la apretada mesa de novedades. Por un lado, el ensayo La vida me sienta mal prolonga la investigación estética sobre lo sublime que el autor ha desarrollado en monografías como El idilio americano (Universidad de Salamanca, 2005) y El poema envenenado (Pre-Textos, 2008, Premio «Amado Alonso»). Por otro lado, el libro de poemas Yo, chatarra, etcétera (El Gaviero, 2015) proyecta sus intuiciones teóricas en un paisaje real y alucinado, mesetario y fabuloso, histórico y goyesco.

En La vida me sienta mal, Santamaría rastrea los orígenes del romanticismo en el tránsito del siglo XVIII al XIX y analiza su repercusión a lo largo de los siglos XIX y XX. El crítico defiende la especificidad de lo romántico como seña de identidad de la cultura contemporánea, ya sea para adherirse a sus principios o para rebatir sus fines. A diferencia de las ideas zombis, que sobreviven tiempo después de su refutación científica, la presencia del romanticismo en nuestros días sigue siendo un asunto complejo y conflictivo. Santamaría nos invita a un recorrido que no sigue el camino de la línea recta, sino que se expande y retrae en idas y vueltas, disquisiciones y merodeos, aceleraciones repentinas y frenazos bruscos. Estructurado en cuatro partes, La vida me sienta mal se lee como un tratado panorámico que sobrevuela algunas nociones y planea sobre determinados conceptos.

La primera parte se centra en la prosa poética, el poema en prosa y la versiprosa. Estas modalidades discursivas son el resultado de un sistema 
de lenguaje que por primera vez admite la representación de «la vida cotidiana en su cotidianidad». Frente a la selva normativa de la Ilustración, a finales del siglo XVIII se abre un nuevo horizonte de expectativas que implica la glorificación de la subjetividad, el triunfo del humorismo, la reivindicación de la arquitectura efímera del fragmento, o la definición de la ironía como una infinitud de contraste en la que se tensan las relaciones perceptuales e intelectuales. La desestabilización de la preceptiva dieciochesca favorece el desbordamiento de los géneros más allá de sus fronteras, así como la identificación del genio creativo con el «ingenio enfermizo». Utilizando como fuentes documentales a los Schlegel, a Chateaubriand y a Novalis, el autor suscribe la existencia de fronteras líquidas entre la prosa y la poesía: mientras que la primera exhibe una «indiferencia suprema» frente a categorías preestablecidas, la segunda aspira a la libertad expresiva sin abdicar de su naturaleza esencial. El punto de sutura entre ambos planteamientos se localiza en el fragmento, que permite acoger todos los acontecimientos de la vida humana bajo la apariencia de una realidad dúctil, maleable y cambiante.

La segunda sección estudia la literatura de viajes como vehículo para la manifestación del "pensamiento errante» que caracteriza al hombre burgués del siglo XVIII. La experiencia formativa del viaje se suma así a la experiencia lectora de guías, itinerarios y diarios. De este modo, la prosa ya no es solo una herramienta artística al servicio de la imaginación, sino un instrumento de alta precisión donde confluyen el mundo exterior y la mirada del turista. En los estertores del siglo XVIII, el viaje evoluciona desde su intención antropológica hasta una dimensión pintoresca en la que tienen cabida la sorpresa, el hallazgo y la imagen deslumbrante. Santamaría ejemplifica esta nueva sensibilidad a través de tres obras: el Diario de a bordo del aeronauta Gianozzo de Jean Paul; el Viaje sentimental por Francia e Italia de Laurence Sterne; y el Viaje de Italia de Leandro Fernández de Moratín. En todas ellas se observa la tendencia a invertir las magnitudes espaciales o a desplazar el foco desde la descripción hasta la introspección. Sin ir más lejos, Jean Paul y Sterne aseguran preferir las «absurdas minucias» de la vida cotidiana a los soberbios espectáculos de la naturaleza. En las letras españolas, ese espíritu contrasublime se encarna en la figura de Leandro Fernández de Moratín, a quien se dedican algunas de las páginas más esclarecedoras de este volumen. Alberto Santamaría parte de la tesis postulada por Luis Felipe Vivanco en Moratín y la Ilustración mágica (1972) para avanzar hacia la recuperación del otro Moratín, escondido bajo la peluca ilustrada: he aquí un personaje 
a medio camino entre el libertino barroco y el cínico proto-romántico, cuyos deseos reformistas chocan a menudo con un temperamento escéptico y desengañado. Según Santamaría, tres rasgos sitúan a Moratín como precursor del romanticismo que pudo haber sido y no fue: su engañosa complicidad con el lector, su ironía «desatada» y su interés por la fragmentación. La prosa de viajes constituiría el germen de ese Moratín extraoficial, pues revela a un individuo más sensitivo que sentimental: un observador que encuentra insospechados pasadizos entre lo urbano y lo natural, entre lo elevado y lo ridículo. Moratín soporta el viaje como una gabela incómoda y peligrosa, pero no cultiva el distanciamiento necesario para suscitar el placer negativo de lo sublime. Por el contrario, en él prevalece el pintoresquismo sobre la ensoñación filosófica o la emoción estética. Otra muestra del «ingenio enfermizo» moratiniano es la edición del Auto de fe de Logroño (1811), que publica bajo el seudónimo del bachiller Ginés de Posadilla. Este texto recoge el proceso inquisitorial contra las brujas de Zugarramurdi, que se celebró en Logroño, en 1610. Frente a la taxonomía científica y a la reflexión erudita que cabría esperar de un ilustrado, Moratín convierte la transcripción del auto de fe en un palimpsesto cargado de anotaciones burlescas, meditaciones sarcásticas y críticas mordaces. Como señala Santamaría, las notas al margen y las glosas trascienden la denuncia de la superstición y se erigen en un juego literario de primer orden, en el que se dan cita la actitud socarrona y la libertad creativa.

En el tercer apartado, Santamaría aborda las modificaciones que la Revolución industrial introduce en el paisaje norteamericano a mediados del siglo XIX. La irrupción del ferrocarril como emblema del progreso no fractura la armonía natural, sino que genera un nuevo modelo de armonía. La escisión entre la mirada atenta y las sacudidas visuales diseña un marco posromántico: la oda a una Arcadia industrial o el canto a un tiempo en marcha. En este sentido, Santamaría interpreta el poema «Ruta de las Indias», de Walt Whitman, como paradigma de una realidad orgánica que sintetiza el sentimiento del paisaje, el asombro ante la tecnología y el nacimiento de una auténtica conciencia nacional.

Por último, la cuarta parte se detiene en la recepción de la herencia romántica a comienzos del siglo XX. Al margen de un romanticismo falso (Benjamin) o «cutáneo» (Ortega), Santamaría profundiza en las conexiones entre imaginación y fantasía a partir de las polémicas en las que participaron Coleridge, Wordsworth o Percy B. Shelley. La prospección en la obra de Wallace Stevens permite comprobar la vigencia del romanticismo 
como una estrategia para reorganizar lo visible y transfigurar los objetos mediante el lenguaje. Ese es el eslabón final en una cadena de montaje que nace de la Ilustración mágica y desemboca en la magia romántica. En suma, este espléndido ensayo demuestra por la vía de los hechos lo que Ortega y Gasset formuló a modo de eslogan: «Todos somos hoy románticos». 
Cecilia Eudave, Diferencias, alteridades e identidad (Narrativa mexicana de la primera mitad del siglo XX), "Cuadernos de América Sin Nombre», núm. 35, prólogo de Carmen Alemany Bay, Alicante, Universidad de Alicante, 2015.

IGNACIO BALLESTER PARDO

Universidad de Alicante

lo que no se mueve se degrada

Cecilia Eudave

Cecilia Eudave (Guadalajara, 1968) es una escritora «inusual». Los ensayos que componen Diferencias, alteridades e identidad (Narrativa mexicana de la primera mitad del siglo XX) tratan un tema universal (la narrativa mexicana) de un modo distinto: mediante un diálogo periférico, analizando las particularidades que nos configuran desde los textos de la Revolución. No es común en la actual crítica literaria releer a este tipo de autores -especialmente los de la primera parte del libro-, por lo que este trabajo resulta indispensable para entender aquellos años (y, por tanto, también estos).

La obra de Cecilia Eudave conjuga la narración y el análisis. El prólogo de este libro es de Carmen Alemany, quien acuñó el término «inusual» para referirse fuera (o un poco más dentro) de lo común tanto a Eudave como a las predecesoras de este tipo de narrativa. Para Alemany, «existe una sutil línea que engarza esta escritura con la ensayística» (p. 10), en el seno de la cual Eudave logra «establecer un contrapunto en la lectura, espacios de discusión» (p. 20).

Diferencias, alteridades e identidad se estructura en tres partes, atendiendo cronológicamente a los textos de la Revolución, postrevolución y contemporaneidad. 
En primer lugar, «Diferencias, alteridades e identidad en la narrativa de la Revolución» recrea la idiosincrasia mexicana en el conflicto a partir del análisis de tres obras. En "Topilejo" de José Vasconcelos: el héroe anónimo de una Revolución traicionada» vemos la evolución histórica de la ideología que caracteriza tanto a Nosotros como a nosotros, es decir, las diversas asociaciones que se gestaron hace ya más de cien años en México, teniendo en cuenta los rasgos distintivos de cada espacio, tiempo y acción. Esta narrativa «intenta crear una atmósfera de introspección, de toma de conciencia y de reflexión» (p. 31). Seguidamente, «La perversión de lo festivo en "La fiesta de las balas" de Martín Luis Guzmán» explica la forma de festejar a la mexicana manera, todavía (guardando las distancias) muy presente. La narración del regocijo de la crueldad, desde las distintas perspectivas que ofrece la otra lectura de Eudave, nos podría servir para purgar «ese rencor que heredamos de una Independencia parcial, de una Revolución fallida, [...] que se instaura, como una de "las revelaciones esenciales" de esta historia narrada con mayúscula, legendaria y atroz» (p. 69). Conocer el crimen y el significado de «Fiesta» nos ayuda a entender el estado actual de México y su narrativa. En tercer y último lugar, «Un sombrero no solo es un sombrero (Reflexión en tránsito)» plantea la importancia y el simbolismo de tan cabal prenda desde Mariano Azuela a Margo Glantz. Narrador y ensayista comparten la fijación por un elemento, a priori, secundario; pero que sigue escondiendo un conejo, que es la literatura (tal como alguna vez Eudave definió este arte al hablar de Cortázar).

Por su parte, «Diferencias, alteridades e identidad en la narrativa de la postrevolución» sigue contando y acotando los rasgos que caracterizan al ser mexicano. "Tipificaciones en torno a la construcción del indígena: "El diosero" de Francisco Rojas González» contrasta las diferencias de clases que se gestaron ya en la conquista. El lenguaje con el que la narración mexicana da voz a los distintos personajes marca ya una distancia entre el nosotros «que solo reconozco si parte de mí mismo» (p. 111) y Nosotros al que venimos aludiendo como reciente tesis de Eudave. En «El Llano en llamas y Pedro Páramo: universos en clausura (Reflexión en tránsito)» la tapatía ubica ambas obras de Rulfo en los límites espaciales que transitarían posteriormente José Emilio Pacheco o Carlos Fuentes, entre otros. Como ocurría anteriormente con el sombrero, el simbolismo adquiere su máxima expresión con la poética de la tierra, vínculo temporal que conecta el pasado y el futuro en un presente maldito, infesta morada de los extremos que nos encierran. «De la geometría enajenada al confinamiento 
identitario: el manejo del espacio en El apando de José Revueltas» ya explica en estos dos sintagmas la claustrofobia textual que hemos sufrido en torno a México y su narrativa. La «geometría enajenada» y el «confinamiento identitario» son el origen y el destino del tránsito penal que sufre la novela breve de Revueltas. A propósito de la caracterización genérica que la propia Eudave traza en En breve: la novela corta en México (2014), El apando reúne en su forma las diferencias, las alteridades (irracionales, animalizadas) y la identidad de la narrativa mexicana en su forma y contenido. Dicha reclusión al cuadrado, textual y vital, continúa caracterizando a la comunicación mexicana y universal a partir de las nuevas tecnologías y redes sociales (o «geometrías enajenadas»). Así lo podemos apreciar en la nueva novela de Eudave, Aislados (2015). Vemos, pues, cómo la narrativa mexicana, desde la Revolución a la actualidad, continúa asociando textos, lugares y tiempos independientes con un lenguaje común: la transgresión. De este modo, en «El otro espacio: la alteridad femenina (Reflexión en tránsito)» la identidad de las mujeres y de las escritoras, tristemente, es una diferencia del conjunto. De nuevo la reclusión gesta una intromisión, esta vez en Ámparo Dávila y su realidad, teniendo en cuenta que «toda obra literaria es ficción en sí misma» (p. 146).

En tercer lugar, «Diferencias, alteridades e identidad en la narrativa desde la contemporaneidad» conecta los más recientes textos con la actualidad narrativa y mexicana. «Tras la huella de una identidad históricamente asumida: Los pasos de López de Jorge Ibargüengoitia» vincula la parodia de los vicios universales con los problemas contemporáneos. La risa -en este y en muchos casos - es la alteridad del llanto. La ironía y el humor negro, paradójicamente, aclaran la historia y sus errores, la Historia y sus mentiras. La precisión con la que Ibargüengoitia emplea las palabras logra generar un espacio autónomo en el que, no obstante, nos reconocemos. Asimismo, «Entre civilizados y bárbaros te veas... Una lectura de Ciudades desiertas de José Agustín» compara a México con EE.UU., analizando un lenguaje colonialista que reduce una América amplísima y haciendo hincapié en la gastronomía como identidad. Las virtudes y los defectos de ambos países suben y bajan, rompiendo la planicie, «el carácter de la horizontalidad como una vía recta que no permite extravío» (p. 183). Eudave, a través de los términos (¿opuestos?) de Domingo Faustino Sarmiento (civilización y barbarie), nos guía en este conocimiento que tanto trabajó ya en su tesis doctoral. Finalmente, «El axolote como analogía identitaria del mexicano del siglo XX» persigue al escurridizo ser «monstrificado» desde una dimensión social que parte de Juan José Arreola y 
Salvador Elizondo, entre otros narradores mexicanos. El origen diferencial que caracteriza al país queda simbolizado por la otredad o la animalización de nuestros comportamientos, apenas murmurados: «lo mexicano es incluido entre paréntesis, que a nivel de la composición es algo que está al margen (lo periférico)» (p. 232); «se necesita del otro (extranjero) para acercarnos a lo propio» (p. 238).

El «Epílogo (Reflexiones en tránsito)» advierte del crecimiento de este axolote que somos: «un pueblo en constante metamorfosis por una serie de tópicos que se arrastran desde la Independencia hasta la fecha» (pp. 243-244). La identidad es algo tan útil y fútil que solo fijándonos en ella podremos poner en tránsito. Implícitamente, los textos analizados tienen en común temas que explican las diferentes épocas a las que se adscriben estas narraciones. Ya sea por el poder, el escarnio o la violencia, el centenario revoltoso continúa competiéndonos.

Estos ensayos son ágiles, discurren ordenadamente por el surco de la Revolución mexicana; ahora bien, el escenario todavía está húmedo, Eudave riega, con sus propias manos, un terreno nada baldío. Rescatar el jolgorio de Martín Luis Guzmán, la estrechez de José Revueltas o la precoz inusualidad de Amparo Dávila permite conectar la narrativa mexicana de la primera mitad del siglo XX con el presente del país y del género; y augurar, incluso, el futuro de ambos.

Lo «inusual» es una cualidad, una alteridad de la identidad general o esperada; pero es también —si consideramos el prefijo no como negación, sino como incisión o profundización de la obra eudaviana - un tránsito vertical que rompe la horizontalidad de la crítica sobre la revolución, ¿mexicana? 


\section{LOS AUTORES}

\section{ElíAS DÍAZ}

Es catedrático emérito de Filosofía del Derecho de la Universidad Autónoma de Madrid y Doctor honoris causa por numerosas universidades europeas. Ha sido Director del Centro de Estudios Políticos y Constitucionales, y obtenido los premios Pablo Iglesias de Ciencias Sociales (1984), Castilla y León de las Ciencias Sociales y la Comunicación (1986), Internacional de Ensayo Caballero Bonald (2009). Su labor intelectual se ha orientado fundamentalmente hacia dos áreas temáticas: por un lado, problemas de filosofía política, jurídica y ética; por otro, historia de las ideas sociales y políticas en la España contemporánea. Entre sus libros, destacan Estado de Derecho y sociedad democrática (1966), Revisión de Unamuno (1968), Sociología y Filosofía del Derecho (1971), La filosofía social del krausismo español (1973), Pensamiento español en la era de Franco (1974), Legalidad-legitimidad en el socialismo democrático (1978), Socialismo en España: el partido y el Estado (1982), De la maldad estatal y la soberanía popular (1984), La transición a la democracia: claves ideológicas (1987), Ética contra política: los intelectuales y el poder (1990), Los viejos maestros: la reconstrucción de la razón (1994), Curso de Filosofía del Derecho (1998), Un itinerario intelectual: de filosofía jurídica y política (2003), De la Institución a la Constitución: política y cultura en la España del siglo XX (2009), El derecho y el poder: realismo crítico y Filosofía del Derecho (2013).

\section{JOSÉ LUIS GONZÁLEZ GERALDO}

Es doctor europeus en Cambio Social y Educación por la Universidad de Castilla-La Mancha y profesor del Departamento de Pedagogía en el área de Teoría e Historia de la Educación de esa misma universidad. Maestro y psicopedagogo (UCLM), especializado en Memoria y Crítica de la Educación (UAH-UNED), ha recibido varios galardones por su actividad 
investigadora, llegando a ser investigador asociado honorífico en la Universidad de Oxford. Sin embargo, y ante todo, se considera un educador vocacional que no tiene otra aspiración que ayudar lo mejor que pueda a sus estudiantes. Tal y como expresa en la dedicatoria de su libro Hacia una universidad más humana: ¿es superior la educación superior? (2014), «[s]in ellos la Universidad es solamente una ilusión, vacía de sentido. Con ellos la Universidad está llena de ilusiones, de sueños por cumplir». Recientemente ha trabajado en la catalogación del archivo recuperado en el centro de la UNED Francisco Giner de los Ríos, en Madrid (2013). Entre sus últimas publicaciones destaca el retrato biográfico El despertar de Prometeo: semblanza del maestro Crédulo M. Escobar (2015).

\section{JOAQUÍN JUAN PENALVA}

Es doctor en Filología Española por la Universidad de Alicante, donde ha sido becario de investigación, y máster en edición por la Universidad de Salamanca y el Grupo Santillana. Profesor de enseñanza secundaria y profesor asociado en la Universidad Miguel Hernández y en la Universidad de Alicante, es autor de los poemarios La tristeza de los sabios (2007; accésit del Premio de Poesía 2006 para Jóvenes Creadores de la Academia Castellana y Leonesa), hiberna, hibernorum (2013) y Anfitriones de una derrota infinita (2015), y, junto a Luis Bagué Quílez, del libro de poemas cinéfilos Babilonia, mon amour (2005; accésit del V Premio «Dionisia García»), y de la plaquette Día del espectador (2009). Ha colaborado en la redacción y edición de Barcelona de los prodigios. Trazado literario de un paisaje urbano (2005). Ha editado la obra del poeta cubano Virgilio Piñera, La vida entera (1937-1977) (2005), y la del chileno Humberto Díaz-Casanueva, El blasfemo coronado (1926-1991) (2006), esta última en colaboración con Luis Bagué. Fue codirector de la revista de poesía Ex Libris y colabora en Arte y Letras, suplemento del diario Información.

\section{RAQUEL LÓPEZ SÁNCHEZ}

Es graduada en Español: Lengua y Literaturas, con mención en Teoría de la Literatura y Literatura Comparada, por la Universidad de Alicante (2014), y ha realizado el Máster en Estudios Literarios en el mismo centro (2015). Ha disfrutado de una Beca de Colaboración del Ministerio de Educación, Cultura y Deporte en el Departamento de Filología Española, Lingüística General y Teoría de la Literatura de la Universidad de Alicante y de una Beca de Iniciación a la Investigación por el Vicerrectorado de 
Investigación, Desarrollo e Innovación. Actualmente, desarrolla su proyecto de Tesis Doctoral en la Universidad Autónoma de Madrid con un contrato predoctoral del Ministerio de Economía y Competitividad, en el proyecto «La metáfora como componente de la Retórica Cultural. Fundamentos y aspectos retóricos, literarios, sociales, ecocríticos y culturales de los mecanismos metafóricos», bajo la tutela del prof. Tomás Albaladejo Mayordomo.

\section{DELIA MANZANERO}

Es licenciada en Filosofía por la UAM, universidad donde realizó el Máster en Filosofía de la Historia: Democracia y Orden Mundial, y en Pensamiento Español e Iberoamericano. Asimismo, ha cursado un Máster en Teoría y Crítica de la Cultura en la Universidad Carlos III de Madrid. Obtuvo su doctorado con Mención Internacional con la tesis Actualidad de la Filosofía del Derecho de Francisco Giner y su ideal krausista de Europa. Su investigación se inscribe dentro del proyecto de investigación «Fundamentos y desarrollo de la idea krausista de Europa: universalismo, internacionalismo, educación y cultura» de la Universidad Pontificia Comillas, dirigido por Ricardo Pinilla Burgos y financiado por el Ministerio de Economía y Competitividad. Algunas de sus líneas de investigación más recientes han sido galardonadas con el Premio Europeo Carlos V (2008) - Javier Solana Madariaga y el primer accésit del III Premio Rafael Altamira (2015). Ha sido visitante académica en las Universidades de Oxford, Nueva York y Pontificia Universidad Javeriana de Bogotá. Actualmente, imparte Introduction to Law y Teoría del Derecho en la Universidad Rey Juan Carlos de Madrid, donde se inscribe su investigación dentro de una Ayuda Posdoctoral Juan de la Cierva. Comparte el mundo académico con el mundo editorial, es presidenta de la Asociación de Filosofía Bajo Palabra y directora de Bajo Palabra (Revista de Filosofía).

\section{Antonio de Murcia CONESA}

Es profesor de Filosofía en la Universidad de Alicante, donde también ha sido docente de Teoría de la Literatura y Literatura Comparada. Ha impartido clases de Hermenéutica e Historia Conceptual en el máster de la UA Metodologías humanísticas, y de Fundamentos de la Memoria Cultural en el título propio de la UCM, Poéticas de la Historia. Doctor en Filosofía por la Universidad de Murcia con una tesis sobre humanismo y filosofía en Ernst R. Curtius, ha editado y traducido una antología de 
textos de Curtius sobre hispanismo y humanismo. Ha publicado artículos en revistas especializadas como $\Delta$ aíuov, Res Publica, Analecta Malacitana o Pasajes, y capítulos en diferentes libros colectivos. Son objeto de sus líneas de investigación el humanismo europeo de entreguerras, la filosofía de la retórica y la literatura, la memoria cultural y la historia de los conceptos. Ha sido investigador invitado en el Instituto Iberoamericano de Berlín, e impartido conferencias en las universidades de Murcia, UCM, Lérida, Facultad de Bellas Artes de la UPV y Pontifica Universidad Católica de Santiago de Chile.

\section{JuAN NAVARRo DE SAN PíO}

Es licenciado en Filosofía y doctor por la Universidad de Valencia con una tesis sobre la estética del paisaje en Ortega y Gasset y en la cultura finisecular, que obtuvo el Premio Extraordinario de Doctorado. Ha publicado artículos y ensayos sobre Ortega y Gasset, Giner de los Ríos, Azorín, Santayana y Wittgenstein. Actualmente es profesor de filosofía en el IES Antonio Navarro Santafé de Villena (Alicante), donde coordina el proyecto «Paisaje: vivencia, comprensión y transformación», que ha sido Premio Nacional de Educación (2013) y Mejor Práctica en el X Concurso Internacional de Buenas Prácticas Ciudadanas de la ONU (2014). Es colaborador habitual del suplemento cultural «Arte y Letras» del diario Información.

\section{Nicolás Ortega CANTERo}

Es catedrático de Geografía Humana de la Universidad Autónoma de Madrid, presidente del Grupo de Historia del Pensamiento Geográfico de la Asociación de Geógrafos Españoles, y miembro fundador del Instituto del Paisaje de la Fundación Duques de Soria, cuyos Seminarios de investigación ha dirigido o codirigido desde 2003. Ha llevado a cabo diversos estudios sobre la conformación de la visión moderna del paisaje, teniendo en cuenta tanto sus componentes naturalistas y geográficos, como sus variadas dimensiones culturales. Dentro de esa perspectiva general, ha considerado también el ámbito español, estudiando los momentos principales de la configuración de la cultura moderna del paisaje en España, con especial atención al papel desempeñado en todo ese proceso por Francisco Giner de los Ríos y la Institución Libre de Enseñanza. Ha publicado varios trabajos sobre esos aspectos, entre los que se cuentan Paisaje y excursiones: Francisco Giner, la Institución Libre de Enseñanza y la Sierra de Guadarrama (2001), y, como editor, los libros que han recogido los resultados 
de los Seminarios del Instituto del Paisaje, tales como Naturaleza y cultura del paisaje (2004), Los valores del paisaje (2009), y Paisaje y patrimonio (2013).

\section{RiCARDO PINILLA BURGOS}

Doctor en Filosofía y Profesor de Estética y Antropología en la Facultad de Ciencias Humanas y Sociales de la Universidad Pontificia Comillas de Madrid, en la que imparte también otras materias, como Historia de la Filosofía Contemporánea, Filosofía Española y seminarios de posgrado sobre experiencia estética y trascendencia. Formó parte desde su fundación del Instituto de Investigación sobre Liberalismo, Krausismo y Masonería, que dirigió E. M. Ureña hasta su fallecimiento. Pertenece al grupo de investigación sobre el krausismo, sucesor del citado instituto, en la Universidad P. Comillas. Ha realizado estudios sobre la estética de Krause y Giner de los Ríos, así como aspectos del pensamiento político y educativo del krausismo. Trabaja también diversos temas de la estética contemporánea y sobre pensamiento musical. Ha sido profesor invitado en la Javeriana de Bogotá, la Universidad de Jena, la Católica de Portugal, la Academia de Bellas Artes de Munich y en diversos conservatorios e instituciones musicales. Desde hace tiempo colabora con Ana María Rabe organizando cursos de posgrado sobre filosofía y estética contemporáneas (Chillida, Heidegger, W. Benjamin, H. Blumenberg...). Ha publicado El pensamiento estético de Krause (2002), Krause y las artes (2013), y numerosas colaboraciones en libros y revistas especializadas. Desde 2012 dirige la revista Pensamiento.

\section{Ángel L. PRieto de Paula}

Es catedrático de Literatura Española de la Universidad de Alicante. Entre sus libros, figuran La llama y la ceniza: introducción a la poesía de Claudio Rodríguez (1989); La lira de Arión: de poesía y poetas españoles del siglo XX (1991); Musa del 68: claves de una generación poética (1996); Contramáscaras (2000); De manantial sereno (2004); Azorín frente a Nietzsche y otros asedios noventayochistas (2006); Literatura española actual (2007; con Mar Langa); Poesía: textos y contextos (2012)... Ha publicado obras de poesía (ed. bilingüe español/francés: Mesure du vide, 2012), trabajos didácticos, ensayos, traducciones en verso (Lucrecio). Ha preparado diversas ediciones con estudio crítico de clásicos y contemporáneos, y prologado obras completas de otros autores; entre ellos, Garcilaso de la Vega, Rodrigo 
Gabaldón, Tomás de Iriarte, José de Espronceda, José Luis Hidalgo, Carlos Salomón, Juan Gil-Albert, Claudio Rodríguez, Antonio Gamoneda, Félix Grande, Antonio Martínez Sarrión, Miguel Veyrat... Ha compilado antologías sobre poesía española de diversas épocas: Poesía del Renacimiento (1989); 1939-1975: Antología de poesía española (1989); Poetas españoles de los cincuenta (1995; 2002); Las moradas del verbo. Poetas españoles de la democracia (2010); Poesía del Romanticismo (2016).

\section{FERRAN RIESGO MARTÍNEZ}

Es licenciado en Filología Hispánica por la Universidad de Alicante (2013), en la que también ha completado un Máster en Estudios Literarios (2014); ha realizado, asimismo, estudios de piano en el Conservatorio de la misma ciudad, y el Máster en Formación del Profesorado en la Universidad Miguel Hernández de Elche (2015). Actualmente cursa el doctorado en Filosofía y Letras bajo la dirección de la catedrática Carmen Alemany, y prepara una tesis titulada «Música y literatura en el Río de la Plata: Roberto Arlt, Ernesto Sábato, Felisberto Hernández y Daniel Moyano». Colabora puntualmente en el Boletín que edita el CeMaB en Alicante, y con la Rassegna Iberistica y el Notiziario del Istituto di Storia dell'Europa Mediterranea de Milán.

\section{BENITO DEL RINCÓN IGEA}

Es maestro, pedagogo, orientador y, actualmente, profesor en la Universidad de Castilla-La Mancha. Admira a los educadores que, como Giner, muestran una coherencia radical entre su «decir» y su «obrar». Investiga sobre tutoría, orientación y docencia universitaria, aunque cree que su labor más importante es formar personas; actualmente, profesionales de la educación. El doctorado en Barcelona le hizo comprender la ineficacia del cambio legislativo en educación y la necesidad de que los avances surjan a pie de obra, de abajo arriba, formando a los protagonistas en sus contextos; por eso, también se ha implicado en la formación permanente del profesorado. Su propia actualización, en los últimos años, se ha centrado en considerar que toda la sociedad, desde sus múltiples instancias, es «educadora», y ha participado en acciones relacionadas con el ocio y tiempo libre, familia y formación de padres. Ha publicado en varias revistas de prestigio y ha coordinado obras como Presente y futuro del trabajo psicopedagógico. 
AdELINA SiRVENT GÁRRIGA

Es maestra de educación infantil por la Universidad de Castilla-La Mancha, licenciada en Ciencias de la Educación por la Universidad de Valencia y doctora en Sociología por la Universidad de Alicante. Defendió su Tesis Doctoral en 2012 con el título de Rodolfo Llopis educador. A la figura de Rodolfo Llopis, tanto en su vertiente política como en la específicamente educativa, ha dedicado monografías como Rodolfo Llopis y el PSOE en el exilio (Albacete, Unoeditorial, 2012) y El ideario pedagógico de Rodolfo Llopis (Alicante, IAC Juan Gil Albert, 2015). Cuenta con diversas publicaciones en revistas especializadas sobre temas pedagógicos, relativas a la enseñanza de la lectura, la educación para la paz, etc. 



\section{NORMAS PARA LA PRESENTACIÓN DE ORIGINALES}

\section{a}

Anales de Literatura Española

(Universidad de Alicante)

- Los artículos deben ser originales, inéditos, escritos en español y no hallarse en proceso de aceptación por otra revista. Para su publicación en ALEUA será necesaria la evaluación positiva de dos expertos, que juzgarán sin conocimiento de su autoría. Deberán remitirse a la dirección de la revista dos copias, una en word y otra en pdf. La extensión máxima será de 10.000 palabras totales.

- El texto irá en páginas numeradas (salvo la primera), a espacio y medio (salvo citas, notas al pie y bibliografía, a un espacio), en letra Times New Roman, cuerpo 12 (salvo título: cuerpo 14; y notas al pie: cuerpo 10). No se cortarán las palabras a fin de línea. El título figurará arriba, centrado, en mayúsculas. Tras dos retornos de párrafo y alineación derecha, se pondrá el nombre del autor, y en renglón inferior y cursiva, centro de procedencia o cargo profesional.

- A continuación, tras tres retornos de párrafo, irá un resumen y una relación de palabras clave en español y en inglés. Los rótulos figurarán a la izquierda, en versalita, separados unos bloques de otros por dos retornos de párrafo: «RESUMEN» (resumen inmediatamente debajo, máximo 150 palabras), «PALABRAS CLAVE:» (escritas a continuación, en cursiva); con las mismas características anteriores, «ABSTRACT»y «KEYWORDS:». El texto comenzará tras tres retornos de párrafo.

- El autor puede distribuir el contenido en apartados, con sus correspondientes titulillos en negrita (precedidos y seguidos de tres y dos retornos de párrafo respectivamente). La primera línea de cada párrafo 
irá sangrada con $1 \mathrm{~cm}$ a la izquierda, excepto en las citas exentas y tras títulos o titulillos, citas exentas, cuadros, tablas o imágenes.

- Se evitarán los recursos tipográficos de énfasis (mayúsculas, negritas, etc.) salvo en los casos especificados, o cuando se usen palabras que así lo exijan. Los números romanos de los siglos irán en versalitas, siempre que no estén en cursiva como en los títulos de un libro: «el siglo XIX» (pero «el siglo XIX»).

- Las citas exentas (4 o más líneas) deben ir con dos retornos de párrafo antes y después, sin entrecomillar, con margen de $1 \mathrm{~cm}$ a ambos lados. Las citas más breves irán a renglón seguido y entrecomilladas (el signo de puntuación final debe quedar fuera de las comillas). En estas, la separación entre versos se indicará con barra transversal precedida y seguida de espacio: «La luna vino a la fragua / con su polisón de nardos». En las citas textuales, la omisión de una parte interior se señalará con [...]; la introducción de palabras o letras no textuales se hará entre corchetes; y para resaltar la literalidad de un término se usará [sic].

- Se usarán comillas latinas o angulares « ». Para distintos rangos de comillas (p. e., un texto entrecomillado dentro de otro también entrecomillado), el orden es este: «latinas» (primer rango), "inglesas" (segundo rango), 'simples' (tercer rango).

- La identificación de la fuente se hará por el sistema americano, en el cuerpo del texto y entre paréntesis (Apellido[s], año de la publicación: página[s]). Si hay varias obras del mismo autor y año, se coloca secuencialmente una letra minúscula junto al año en la bibliografía final, y así se reproducirá aquí (1987a, 1987b). Si se ha citado al autor en el cuerpo del texto, solo se especifica año y página(s); si se ha citado también la obra, solo página(s); si la referencia es a la obra en general, no se pone página. En la referencia a un trabajo de un autor inserto en un libro colectivo, antología, etc., debe especificarse el autor de la cita y el editor en cuya obra está inserta. Para páginas consecutivas, puede especificarse el número de la primera más «ss.»: (Silver, 1996: 13 ss.); y si se referencian contenidos dispersos en la obra, se especifica «passim»: (Silver, 1996: passim). Ejemplos:

- Resulta evidente la precariedad del Romanticismo español (Silver, 1996: 123-124). 
- Para Silver, es evidente la precariedad del Romanticismo español (1996: 123-124).

- En esa misma obra queda clara la precariedad del Romanticismo español (123-124).

- Ya hay estudios sobre la precariedad del Romanticismo español (Silver, 1996).

- Para Lanz, el fragmento «habita el espacio de la indeterminación» (en Abril, 2011: 13).

- El fragmento «habita el espacio de la indeterminación» (Lanz, en Abril, 2011: 13).

- Para el caso de que haya más de un autor, se procede así: (Pérez \& Rosales, 1972: 134) [dos autores]; (Pérez, Rosales \& Ramírez, 1973: 233) [tres]; (Pérez et al., 1973: 233) [cuatro o más]; (AA. VV., 1975: 201-202)... [autores varios]. Si hay referencia a dos o más obras del mismo autor, o de distintos autores, se procede así: (Silver, 1996 y 2003) [dos obras del mismo autor, sin páginas]; (Silver, 1996: 123; y 2003: 107) [lo mismo, con páginas]; (Silver, 1996; Cárdenas, 2001; Salazar, 2007) [tres autores, sin páginas].

- Las notas al pie, si las hubiere, deben reservarse para comentarios o excursos necesarios. Si contuvieran referencias bibliográficas, rige el procedimiento señalado. La llamada a nota se hará con número volado a partir del 1, fuera de las comillas de cierre, si las hay, y antes del signo de puntuación de separación (coma, punto, punto y coma, puntos suspensivos) pero después de los de cierre expresivo (interrogación, admiración).

- Al final irá una «Bibliografía citada» donde figuren todas las obras referidas en texto y notas. El rótulo se pondrá en negrita, centrado, precedido y seguido de tres y dos retornos de párrafo respectivamente. Las entradas se dispondrán en párrafo francés (de $1 \mathrm{~cm}$ ), y sus datos se separan por comas. Regirá el orden alfabético de apellidos de autores; en un autor con varias obras, el cronológico de publicación; y si tiene varias del mismo año, se coloca una letra minúscula junto al año: 1987a, 1987b. Cuando la misma persona figure unas veces como autor, otras como editor..., la secuencia es esta: primero autor único, luego editor (coordinador...), por fin coautor. En estos casos de un 
autor con varias obras, la indicación de autoría (Apellido, Nombre,) se pone solo la primera vez; luego se sustituye por raya (sin coma).

- Si se trata de un libro, se seguirá este orden: Apellido, Nombre [completo o con inicial], Título del libro, Ciudad [en el idioma original], Editorial [o Imprenta, en libros antiguos], año. Cuando la obra consta de varios volúmenes, se indicará tras el título con números arábigos ( 5 vols.), si se cita en su conjunto, o con romanos (IV) el volumen referido específicamente. Si se cita una reedición de una obra, pero se desea hacer constar el año de la primera edición, se pondrá este entre corchetes [ ], antes de la coma que separa el nombre del autor y el título de la obra. Si hay hasta tres autores, se nombra a todos (desde el segundo, el orden se invierte: Nombre Apellido): Forradellas, E., J. Reboredo \& A. Sanjuán); si cuatro o más, al primero seguido de et al. (o bien: AA. VV.). En las obras colectivas, suele figurar alguien como editor, director, etc., en cuyo caso se especifica su condición entre paréntesis: Forradellas, E. (ed.). Cuando se trata de la obra de un clásico al cuidado de un editor literario, tras el autor y el título, se especifica «ed.»y-sin preposición «de»- Nombre Apellido del editor; lo mismo en el caso de un traductor («trad.») o prologuista («pról.»): Bécquer, G. A., Rimas, ed. J. M. Díez Taboada, Madrid, Alcalá, 1965.

- Si citamos un capítulo de un libro colectivo, la secuencia es: Apellido, Nombre [del autor del capítulo], «Título del capítulo», en AA. VV. [o, en su caso: Nombre Apellido (ed.)], Título del libro, Ciudad, Editorial, año, pp. primera-última. Similares criterios se adoptan cuando se cita un prólogo, epílogo, etc., de un autor distinto al del libro.

- Si se trata de un artículo de revista, se procede así: Apellido, Nombre, «Título del artículo», Nombre de la Revista, número en arábigos (año), pp. primera-última. Si el nombre de la revista tiene varias palabras, llevan inicial mayúscula todos los términos con valor semántico: Caballo Verde para la Poesía.

- Si se trata de un artículo en un diario, se cita igual que en una revista hasta el título de la publicación; a partir de ahí, se hace constar la fecha: 25 de abril de 1989.

- Para citar publicaciones en soporte electrónico o en línea, las reglas son las usuales. En las publicaciones en soporte electrónico debe especificarse al final, tras punto y coma, el soporte en cuestión (CD, DVD). 
En las publicaciones en línea debe especificarse al final, tras punto y coma, la dirección URL entre comillas simples angulares $<>$, y a continuación, entre corchetes, la fecha de la consulta: [consulta: 12 enero 2013].

- He aquí una relación bibliográfica a modo de ejemplo, según las normas especificadas:

Abellán, J. L. [1979], Historia crítica del pensamiento español, I, Barcelona, Círculo de Lectores, 1992.

Abril, J. C. (ed.), Campos magnéticos, Monterrey (México), Universidad Autónoma de Nuevo León, 2011 la.

- (ed.), Gramáticas del fragmento, Granada, El Genio Maligno, 2011b.

Cotarelo y Mori, E., «La fundación de la Academia Española y su primer director D. Juan Manuel F. Pacheco, Marqués de Villena», Boletín de la Real Academia Española, 1 (1914), pp. 4-38 y 89-127.

Egido, A., «Una introducción a la poesía y a las academias literarias del siglo XVII», Estudios Humanísticos. Filología, 6 (1984), pp. 9-26.

— «Emblemática y literatura en el Siglo de Oro», Ephialte, 2 (1990), pp. 144-158.

Góngora, L. de, Soledades, ed. D. Alonso, Madrid, Revista de Occidente, 1927.

Henry, A. (ed.), Schopenhauer et la création littéraire en Europe, Paris, Méridiens Klincksieck, 1989.

Krause, A., Azorín, el pequeño filósofo, Madrid, Espasa-Calpe, 1955.

Leopardi, G. [1975], Canti, Milán, Garzanti, 1989.

Llanos de los Reyes, M., «Perfil de Pedro Jara Carrillo», Tonos, 4 (2002); <http://www.um.es/tonosdigital/znum4/perfiles/PerfilJaraCarrillo.htm> [consulta: 26 abril 2013].

Maceiras, M., Schopenhauer y Kierkegaard: sentimiento y pasión, Madrid, Cincel, 1985.

Mary, A., Tristán, trad. E. Galvarriato, Barcelona, José Janés, 1947.

Oliver, A., «Murcia y Salvador Rueda», La Verdad, 21 de julio de 1957, p. 16.

Oteo Sans, R., «Prólogo» a J. González Soto, La palabra labrada. La poesía de Luis López Álvarez, Barcelona, PPU, 1995, pp. I-III.

Robles Vázquez, G., Negaciones subintuicionistas para lógicas con la Conversa de la Propiedad Ackermann, Salamanca, Universidad de Salamanca, 2006; $1 \mathrm{CD}$.

Ros de Olano, A., Poesías, pról. P. A. de Alarcón, Madrid, Imprenta y Fundición de M. Tello, 1886. 
Savater, F., «Schopenhauer», en V. Camps (ed.), Historia de la ética, II, Barcelona, Crítica, 1992.

Schopenhauer, A., Metafísica de las costumbres, trad. R. Rodríguez Aramayo, Madrid, Debate / CSIC, 1993.

- Parábolas, aforismos y comparaciones, ed. y trad. Á. Sánchez Pascual, Barcelona, Edhasa, 1995.

- Si hay que incluir anexos documentales, deberán situarse tras la bibliografía, en hojas aparte, numerados (ANEXO I, ANEXO II...) y con el rótulo correspondiente.

- Si el artículo precisa ilustraciones, estas han de presentarse en CD aparte, con buena resolución y formato jpg, indicando su ubicación y el rótulo que debe acompañarlas al pie. Cada autor garantiza con la mera presentación que este material es original o puede ser legalmente reproducido. 


\title{
SERIE MONOGRÁFICA DE ANALES DE LITERATURA ESPAÑOLA
}

\author{
La novela española del siglo XVIII, 1 (1995) \\ Edición de Guillermo Carnero
}

Guillermo Carnero, «La novela española del siglo XVIII: estado de la cuestión (19851995)».- J. Alonso Seoane, «Infelices extremos de sensibilidad en las Lecturas de Olavide».- J. Álvarez Barrientos, «El Emprendedor (1805), novela de aventuras original de Jerónimo Martín de Bernardo».- R. Benítez, «Vargas, novela española de Blanco White».- G. Dufour, «Elementos novelescos de El evangelio en triunfo de Olavide».- A. Fernández Insuela, «Acercamiento a una novela por entregas dieciochescas: Zumbas, de José de Santos Capuano».- M. J. García Garrosa, «La Leandra, novela moral».- M. Z. Hafter, «Sabina y Dorotea, a forgotten novel of 1797».- J. Pérez Magallón, «Epistolaridad y novela: Afán de Ribera y Cadalso».- Russell P. Sebold, «Novelas de "muchos Cervantes": Olavide y el realismo».- I. Urzainqui, «Autocreación y formas autobiográficas en la prensa crítica del siglo XVIII».

\section{Schopenhauer y la creación literaria en España, 2 (1996) Edición de M. Á. Lozano Marco}

A. Sotelo Vázquez, «Schopenhauer, Zola y Clarín».- Cecilio Alonso, «Notas sobre el pesimismo activo en la literatura española hacia 1900 (un fin de siglo entre la voluntad y el dolor de vivir».- Ángel L. Prieto de Paula, «Schopenhauer y la formalización de la melancolía en las letras españolas del Novecientos».- R. de la Fuente Ballesteros, «Ganivet y Schopenhauer: pensadores intempestivos».- P. Ribas, «Unamuno y Schopenhauer: el mundo onírico».- J. Verdú de Gregorio, «Huellas de Schopenhauer en la novela de Unamuno (San Manuel Bueno, mártir)».- F. Abad Nebot, «Schopenhauer y el joven Baroja (el léxico del dolor y de la compasión)».D. Ordoñez García, «Baroja y Schopenhauer: implicaciones narrativas del mundo como representación».- Roberta Johnson, «La voluntad de Azorín. Schopenhauer bajo prueba».- M. Á. Lozano Marco, «Schopenhauer en Azorín. La "necesidad de una metafísica”».- C. E. García Lara, «Schopenhauer en la perspectiva de Ortega». 


\title{
Letras novohispanas, 3 (1999)
}

\author{
Edición de M. Á. Méndez \& J. C. Rovira
}

Ó. A. García Gutiérrez, «Fray Toribio Motolinía: la visión urbana de un cronista novohispano».- B. Aracil Varón, «Del texto literario a la representación popular sobre la conquista: La destrucción de Jerusalén».- Teodosio Fernández, «Sobre el teatro de Fernán González de Eslava».- B. Mariscal Hay, «"Entre los juncos, entre las cañas": los indios en la fiesta jesuita novohispana».- S. Poot Herrera, "Sor Juana: nuevos hallazgos, viejas relaciones».- P. A. J. Brescia, «Las razones de sor Juana Inés de la Cruz».- Margo Glantz, «El jeroglífico del sentimiento: la poesía amorosa de sor Juana».- Aurelio González, «Construcción teatral del festejo barroco: Los empeños de una casa de sor Juana».- Octavio Rivera, «Teatro y poder en el virreinato de Nueva España: las loas profanas de sor Juana Inés de la Cruz».- M. Á. Méndez, «Antonio Núñez de Miranda, confesor de sor Juana: un administrador poco común».- M. ${ }^{a}$ D. Bravo Arriaga, «Algunas consideraciones sobre el discurso del poder y la autoría de Núñez de Miranda, en el Túmulo a Felipe IV, de 1666».- M. ${ }^{a}$ C. Espinosa, «La palabra conquistadora. Las crónicas jesuitas sobre el noroeste novohispano».- C. Comes Peña, «La formulación del criollismo en Juan José de Eguiara y Eguren».José Carlos Rovira, «El bibliógrafo Beristáin en una contienda poética desde los balcones a fines de 1796».

\section{Memorias y autobiografías, 4 (2000-2001) Edición de M. ${ }^{a}$ Ángeles Ayala}

M. ${ }^{a}$ Ángeles Ayala, «Impresiones y recuerdos de Julio Nombela».- Anna Caballé, «Escribir el pasado, yendo al futuro».- F. Durán López, «Las Memorias de un setentón de Mesonero Romanos en el marco de la autobiografía española decimonónica».- S. García Castañeda, «Las reminiscencias de Pereda».- J. Juan Penalva, «Descargos, diarios y palinodias: algunos ejemplos de literatura memorialística en la generación del 36».-Á. G. Loureiro, «Autobiografía: el rehén singular y la oreja invisible».- M. Á. Lozano Marco, «Recuerdos de niñez y de mocedad. Unamuno y "el alma de la niñez"».- Remedios Mataix, «Cualquier parecido con la realidad no es mera coincidencia: Alfredo Bryce Echenique y la reescritura de la vida».- J. A. Ríos Carratalá, «Los cómicos españoles y sus memorias».- José Carlos Rovira, «José María Arguedas y la memoria autobiográfica del indigenismo contemporáneo»-E. Rubio Cremades, «Visión y análisis de la prensa en Memorias de un setentón, de Ramón Mesonero Romanos». 


\section{Simbolismo y modernismo, 5 (2002) \\ Edición de M. Á. Lozano Marco}

Guillermo Carnero, «La ruptura modernista».- R. A. Cardwell, «"La poesía moderna, modernísima, poesía, quizás, del futuro". Los orígenes del simbolismo en España».- Ángel L. Prieto de Paula, «Subjetivación, irracionalismo, música: rasgos del simbolismo en la poesía española hacia 1900».- R. Alarcón Sierra, «Valores simbolistas en la literatura española del primer tercio del siglo XX».- M. ${ }^{a}$ P. Celma Valero, «Miguel de Unamuno, poeta simbolista».- César Oliva, «El simbolismo en el teatro de Valle Indán».- M. Á. Lozano Marco, «Azorín y la sensibilidad simbolista».F. J. Blasco Pascual, «Del modernismo a la vanguardia: el Diario de un poeta recién casado».- J. M. ${ }^{a}$ Ferri Coll, «"Oh, quién fuera hipsipila que dejó la crisálida". Raíz y sentido de una figuración simbólica en la poesía del novecientos».- J. L. Bernal Muñoz, «El color en la literatura del Modernismo».- E. Trenc, «Texto e imagen en A. de Riquer: dos lenguajes para una misma cosmovisión».- F. Fontbona de Vallescar, «Las raíces simbolistas del Art Nouveau».- X. Aviñoa, «El teatre líric català: antecedents, desenvolupament i epígons (1894-1908). Laportació musical, plastica i literaria».-J. Bassegoda i Nonell, «Símbolos y simbolismos ciertos y falsos en la obra de Antonio Gaudí».- Jorge Urrutia, «El retorno de Cristo, tipo y mito».

\section{Narradoras hispanoamericanas desde la independencia a nuestros días, 6 (2003) Edición de Carmen Alemany Bay}

Remedios Mataix, «La escritura (casi) invisible. Narradoras hispanoamericanas del siglo XX».- Paco Tovar, «Estrategias de seducción en un artificio epistolar de Gertrudis Gómez de Avellaneda: Diario de un amor».- Trinidad Barrera, «La narrativa femenina: balance de un siglo».- Carmen Alemany, «Muestrario de narradoras hispanoamericanas del siglo xx: mucho ruido y muchas nueces».- Paola Madrid, «Una aproximación a la ficción narrativa de escritoras mexicanas contemporáneas: de los ecos del pasado a las voces del presente».- Margo Glantz, «Vigencia de Nellie Campobello».- M. Ruiz Bañuls, «Luces y sombras de una mística española: Morada interior de Angelina Muñiz-Huberman ».- Teodosio Fernández, «Del lado del misterio: los relatos de Silvina Ocampo».- María Bermúdez, «La narrativa de Silvina Ocampo: entre la tradición y la vanguardia».- Eva Valero, «El desconcierto de la realidad en la narrativa de M. ${ }^{a}$ Luisa Bombal».- María Caballero, «Rosario Ferré y Virginia Woolf, o del impacto de ciertos feminismos en Hispanoamérica».- Beatriz Aracil, «Margo Glantz: el rastro de la escritura». 


\section{Literatura española desde 1975, 7 (2004) \\ Edición de J. M. Ferri Coll \& Ángel L. Prieto de Paula}

L. Bagué Quílez, «Entre clasicismo y vanguardia: el compromiso poético en los autores de los años ochenta».- J. M. ${ }^{a}$ Ferri Coll, «Itálica abolida: una colección de vanitas en la poesía española contemporánea.- J. Gómez Capuz, «La poética del pop: los recursos retóricos en las letras del pop español».- F. Gutiérrez Carbajo, «La pragmática teatral en Alfonso Vallejo».- J. Juan Penalva, «De cómo el roman fusion llego a serlo: prehistoria literaria de una nueva fórmula narrativa».- M. Langa Pizarro, «La novela histórica española en la transición y en la democracia».- A. Méndez Rubio, «Memorias de la desaparición: notas sobre poesía y poder».- Mariano de Paco, «El teatro español en la transición: ¿una generación olvidada?».- Ángel L. Prieto de Paula, «Poetas del 68... después de 1975».- J. A. Ríos Carratalá, «Humor para una nueva etapa histórica: Manicòmic, de Tricicle».- Laura Scarano, «Políticas de la palabra en el debate poético español contemporáneo».

\section{Romanticismo español e hispanoamericano Homenaje al profesor Ermanno Caldera, 8 (2005) Edición de Enrique Rubio Cremades}

M. ${ }^{a}$ J. Alonso Seoane, «Algunos datos sobre José Bermúdez de Castro y un primer acercamiento a sus colaboraciones en La Revista Española (1836)».- J. Álvarez Barrientos, «Ramón de Mesonero Romanos y el Panteón de hombres ilustres».- M. ${ }^{a}$ Ángeles Ayala, «Ángela Grassi, del romanticismo al dualismo moral».- A. Calderone, «Estética romántica de la arqueología: la poética de las ruinas en José María Heredia».- R. Charques Gámez, «¿Un cuento antirromántico de Juan Eugenio Hartzenbusch?».- L. F. Díaz Larios, "Trafalgar (1805): política, literatura y mito».- José Escobar, «Un tema costumbrista: las horas de la ciudad».- M. ${ }^{a}$ P. Espín Templado, «Las ideas literarias en la prensa de la época romántica: el debate Sobre la influencia del teatro en las costumbres (a propósito de varios artículos de Miguel Agustín Príncipe)».- H. Establier Pérez, «El teatro mágico de María Rosa Gálvez de Cabrera en el tránsito de la Ilustración al Romanticismo: una utopía femenina y feminista».- Ana M. ${ }^{a}$ Freire, «Un negocio editorial romántico (Aribau y Walter Scott)».- S. García Castañeda, «Terpsícore montañesa. Bailes y bailarines en el Santander decomonónico».- P. Garelli, «A modo de prólogo: Marcela, o ¿cuál de los tres?, comedia de Bretón de los Herreros.- D. T. Gies, «Romanticismo e histeria en España».- J. L. González Subías, «Un manuscrito "apócrifo" de Don Álvaro o la fuerza del sino».- Francisco Lafarga, «Teatro y traducción a las puertas del Romanticismo: presencia de tragedias 
de Voltaire durante el Trienio Constitucional».- Marina Mayoral, «Magia y humor en un relato de Álvaro Cunqueiro».- P. Menarini, «El problema de la autoría en la prensa romántica: apuntes sobre destinatarios, erratas e imposturas».- V. M. Peláez, «Propuesta de historia espectacular de la parodia del Romanticismo».- S. Pujol Rossel, «La mujer: una visión de época. De la necesaria documentación histórica».M. Ribao Pereira, «Poderosos y tiranos en la primera parte de El zapatero y el rey».A. Romero Ferrer, «La escena del siglo XIX, domicilio de todas las artes».- L. Romero Tobar, «Valera escribe un soneto de Zorrilla: sobre la hermandad lírica de los románticos».- E. Rubio Cremades, «Una visión del drama El Trovador, de A. García Gutiérrez: la novela homónima de R. Ortega y Frías».- Eva Valero, «El costumbrismo y la bohemia romántica en el Perú: un tránsito hacia la tradición».

\section{Humor y humoristas en la España del franquismo, 9 (2007) Edición de J. A. Ríos Carratalá}

S. Aguilar Alvear, «José Santugini: el humorista seducido por la señorita cinematografía».- M. ${ }^{a}$ L. Burguesa Nadal, «La venganza de Don Mendo o la parodia como desafío a la estética realista».- J. M. ${ }^{a}$ Ferri Coll, «La narrativa humorística de un novelista serio: Antonio Mingote».- M. ${ }^{a}$ T. García-Abad García, «Literatura, disparate y humor en Manicomio, de Fernando Fernán-Gómez».- V. García Ruiz, «Tres humoristas en busca del teatro: Mihura, López Rubio y Neville hacia 1950».- F. Gutiérrez Carbajo, «Representación del teatro cómico de Pío Baroja: El horroroso crimen de Peñaranda del Campo».- J. A. Llera, «Documentos inéditos sobre La Ametralladora y La Codorniz de Miguel Mihura».- P. I. López García, «Julio Camba a través de su epistolario».-J. Moreno, «María de la Hoz: Tono y Mihura en las trincheras».- V. M. Peláez, «Aproximación al humor de Tono».- J. A. Pérez-Bowie, «La función paródica de las estrategias metaficcionales. Apuntes sobre la adaptación cinematográfica de la zarzuela Doña Francisquita».- E. Pérez-Rasilla, «El humor en los personajes de Alfonso Paso».- J. A. Ríos Carratalá, «El verdugo (1964) y la tragedia grotesca».- M. ${ }^{a}$ V. Sotomayor, «El humor en la literatura infantil del franquismo ».- G. Torres Nebrera, «Espectáculos teatrales como escorzos narrativos en Neville: cine, toros y teatro».

\section{Escritores olvidados, raros y marginados, 10 (2008) Edición de Enrique Rubio Cremades}

Cecilio Alonso, «Sobre la categoría de raros y olvidados».- J. Álvarez Barrientos, «Fray Ramón Valvidares y Longo (1769-1826), escritor político y antimoderno».-M. ${ }^{a}$ 
Ángeles Ayala, «Una Eva moderna, última novela de Concepción Gimeno de Flaquen».- Ana L. Baquero Escudero, «Las novelas históricas olvidadas de Blasco Ibáñez».- R. Charques Gámez, «La Baronesa de Wilson. Colaboraciones en La Ilustración Artística de Barcelona».- Luis F. Díaz Larios, «Notas sobre Antonio Ribot y Fontseré».- F. J. Díez de Revenga, «Eliodoro Puche, un raro y olvidado entre simbolismo y vanguardia».- H. Establier Pérez, «Las "luces" de Sara Th***. María Antonia del Río Arrendó y su traducción dieciochesca del Marqués de Saint-Lambert».- J. M. ${ }^{a}$ Ferri Coll, «El Libro de la Academia de los Nocturnos».- Ana M. ${ }^{a}$ Freire, «Carta a una desconocida (con Gertrudis Gómez de Avellaneda al fondo)».- S. García Castañeda, «Vanitas vanitatis: las ferias de Madrid».- David T. Gies, «El otro Larra: Luis Mariano de Larra y Wetoret, dramaturgo "desconocido" de la segunda mitad del siglo XIX (con apéndice de títulos)».- J. A. Ríos Carratalá, «Versos a medianoche en el Café Varela».- L. Romero Tobar, «Ausencias en el canon de la narrativa actual: Santiago Rodríguez Santerbás».- E. Rubio Cremades, «El crimen de Villaviciosa, de Ramón de Navarrete: entre la crónica de sociedad y el relato de misterio».- Eva Valero, «Geografías de poesía y vida en los Cinco metros de Carlos Oquendo de Amat».

\section{La memoria literaria del franquismo, 11 (2009)} Edición de J. A. Ríos Carratalá

José Paulino Ayuso, «Los dramas de la conciencia y la memoria».- Francisco Caudet, «¿Será ya todo silencio?».- F. Gutiérrez Carbajo, «La memoria de Julio Diamante».- J. Juan Penalva, «Diario y Los cuadernos de Segovia: La memoria póstuma de Luis Felipe Vivanco».- Juan José Lanz, «La memoria y su silencio: Descripción de la mentira (1977), de Antonio Gamoneda, y la memoria callada del franquismo y de la transición».- Ermitas Penas, «La vigencia de la novela de aprendizaje: un análisis de Carreteras secundarias, de Martínez de Pisón y El viento de la luna, de Muños Molina».- E. Pérez-Rasilla, «La memoria histórica de la posguerra en el teatro de la transición. La generación de 1982».- J. A. Ríos Carratalá, «El paraíso ibicenco y Rafael Azcona».- J. Romera Castillo, «La memoria histórica de algunas mujeres antifranquistas».- G. Torres-Nebrera, «Imágenes fílmicas de la España del franquismo».- R. Utrera Macías, «Raza, novela de Jaime de Andrade, seudónimo de Francisco Franco». 
Novela lírica y novela poemática en el modernismo español, 12 (2010) Edición de M. Á. Lozano Marco

A. Sotelo Vázquez, «Leopoldo Alas, narrador en el fin-de-siècle: ética y estética».Ángel L. Prieto de Paula, «Unamuno: la abolición del género novela».- R. Charques Gámez, «En torno a Flor de santidad, novela poemática de Valle-Inclán».- F. Ezpeleta Aguilar, «Formación y maestro en La voluntad de Azorín».- J. M. ${ }^{a}$ Ferri Coll, «Una isla propia: sobre una novela poemática de Azorín».- Dolores Thion, «Renovar novelando: lo apolíneo y lo dionisíaco en Las cerezas del cementerio de Gabriel Miró».- M. Á. Lozano Marco, «La inspiración bíblica como materia estética en la narrativa de Gabriel Miró».- Kevin S. Larsen, «Miró y Midrash: el caso de Figuras de la Pasión del Señor».- José Ramón González, «El perspectivismo lírico de Ramón Pérez de Ayala».- Amelina Correa Ramón, «Una novela lírica de la tierra de los faraones: La serpiente de Egipto, de Isaac Muñoz».- Begoña Sáez Martínez, «Lirismos negros, novelas canallas: Las lobas de arrabal, por Antonio de Hoyos y Vinent».

\section{«Cantad, hermosas». Escritoras ilustradas y románticas, 13 (2011) Edición de Helena Establier Pérez}

M. Angulo Egea, «Hombre o mujer, cuestión de apariencia. Un caso de travestismo en el teatro del siglo XVIII».- M. ${ }^{a}$ J. García Garrosa, «La otra voz de María Rosa de Gálvez: las traducciones de una dramaturga neoclásica».- F. Morand, «Influencias medievales y originalidad en la literatura española de finales del setecientos: el caso de la gaditana María Gertrudis de Hore».- H. Establier Pérez, "Las esclavas amazonas (1805) de María Rosa de Gálvez en la comedia popular de entresiglos».- E. Palacios Fernández, «Bibliografía general de escritoras españolas del siglo XVIII».- E. Franklin Lewis, «La caridad de una mujer: modernización y ambivalencia sentimental en la escritura femenina decimonónica».- M. Cantos Casenave, «Escritura y mujer 1808-1838: los casos de Frasquita Larrea, M. ${ }^{a}$ Manuela López de Ulloa y Vicenta Matura de Gutiérrez».- R. Haidt, «Sobre la dificultad de ser Carolina Coronado: contemplación y praxis fenomenológica».- E. Penas Varela, «Juana de Vega desde la literatura del yo».- M. ${ }^{a}$ C. Simón Palmer, «En busca del mecenazgo real: autoras románticas y Palacio».- R. Fernández Cabezón, «Una voz femenina en el teatro de mediados del XIX: la comedia de Gertrudis Gómez de Avellaneda».- Ángeles Ezama, «Los relatos de viaje de Gertrudis Gómez de Avellaneda».- R. Charques Gámez, «Sab y el juego de las miradas».- M. ${ }^{a}$ Ángeles Ayala, «El testamento de D. Juan I, novela histórica de una escritora olvidada: Teresa Arróniz y Bosch».- Dolores Thion, «Joaquina García Balmaseda: una escritora isabelina al servicio de la mujer». 


\section{Literatura y espacio urbano, 14 (2012) Edición de M. ${ }^{a}$ Ángeles Ayala}

S. García Castañeda, «El peligroso Madrid de las aleluyas».- Mónica Fuentes, «Madrid en los artículos satíricos costumbristas de Modesto Lafuente».- Borja Rodríguez, «Ramón de Navarrete y Misterios del corazón (1845): ciudad del lujo y del glamour».- Ana M. ${ }^{a}$ Freire, «España y la literatura de viajes del siglo XIX».- Yvan Lissorgues, «Los espacios urbanos de la miseria en algunas novelas del siglo XIX. Una estética de la verdad».- J. M. González Herrán, «El Santander de Pereda: Sotile$z a$ (1885) y Nubes de estío (1891)».- Raquel Gutiérrez, «Luces y sombras de Madrid en la narrativa de Pereda».- Fanny Vienne, «Urbanografía: el caso de Pedro Sánchez, de Pereda y Fortunata y Jacinta, de Pérez Galdós».- Germán Gullón, «El Madrid de Galdós: de la calle a la vía urbana».- Ermitas Penas, "Gerona, de Galdós: en el espacio heroico».- M. ${ }^{a}$ Ángeles Ayala, «Galdós, flâneur y peregrino por Inglaterra: La casa de Shakespeare».- Dolores Thion, «Realismo y espacio urbano: notas sobre La Tribuna de Emilia Pardo Bazán».- R. Charques Gámez, «Recorriendo Madrid. Una cristiana y La prueba de Emilia Pardo Bazán».- Monserrat Ribao, «De la corte trovadoresca a la urbe de las maravillas: la ciudad en el teatro de Emilia Pardo Bazán».Isabel Román Román, «La descripción de espacios urbanos y sus convenciones del romanticismo a la novela intelectual».-Solange Hibbs, «La ciudad como espacio de transgresión y decadencia en la novela finisecular. La trilogía La lucha por la vida de Pío Baroja».- Fernando Romera Galán, «Las ciudades escriben su autobiografía. Espacio urbano y escritura autobiográfica».- Marisa Sotelo, «Espacio urbano y guerra civil en Luciérnagas de Ana María Matute».- Juan Antonio Ríos, «Un flâneur en Nueva York y Holanda: Jacinto Miquelarena».- Carmen Servén, «Los barrios de Elvira Lindo».- Mercedes Cano, «Doce cuentos peregrinos o el espacio de la pérdida: Gabriel García Márquez en el laberinto europeo».- Gregorio Martín, «Ciudad e identidad en La cátedra de la calavera».

\section{Revistas literarias españolas e hispanoamericanas (1835-1868), 15 (2013)}

\section{Edición de J. M. ${ }^{a}$ Ferri Coll \& E. Rubio Cremades}

M. ${ }^{a}$ José Alonso Seoane, «La participación del Conde de Campo Alange en El Artista en los tres primeros meses de 1835».- Cecilio Alonso, «Las revistas de actualidad, germen de la crónica literaria. Algunas calas en la evolución de un género periodístico entre 1845 y 1868».- Antonio Arroyo Alamaraz, "Ángel Saavedra, Duque de Rivas, en las revistas literarias españolas».- M. ${ }^{a}$ Ángeles Ayala, «El Artista (Madrid, 
1835-1836), fuente literaria de El Recreo de las Familias (México, 1837-1838)».Marieta Cantos Casenave, «Los dispositivos óptico y su recepción en la prensa del romanticismo (1835-1868). Una aproximación».- J. M. ${ }^{a}$ Ferri Coll \& Eva Valero, «Las dos Españas y la emancipación literaria americana en El Iniciador de Montevideo».- Marina Gacto Sánchez, «La estimación del artista dieciochesco a través de la estética romántica en la prensa ilustrada española».- S. García Castañeda, «Costumbrismo y prensa en la Cantabria del siglo XIX».- Raquel Gutiérrez Sebastián, «Usos, tipos, modas y costumbres del medio siglo. El costumbrismo en $\mathrm{La}$ Ilustración».- Luis Marcelo Martino, «Lecturas transatlánticas. Letras españolas en El Iniciador (Montevideo, 1838-1839)».- Ángeles Quesada Novás, «La Ilustración. Periódico universal (1849-1857). Panorámica general».-Franco Quinzano, «Prensa periódica, política y campo cultural en el Río de la Plata. Pedro de Angelis, "escritor oficial" ».- Borja Rodríguez, «La narrativa en La Ilustración (1849-1857): la "Serie B" del Seminario Pintoresco Español».- L. Romero Tobar, «El Belén (1857), periódico de un día de los últimos románticos».- E. Rubio Cremades, «Hispanoamérica y España a mediados del siglo XIX: el editor Francisco de Paula Mellado en la Revista Española de Ambos Mundos».- Dolores Thion, "Antonio Berges de las Casas, un editor para todos. De los primeros pasos en el gremio a El Museo de las Familias».- Nadia Vaíllo, «Crítica teatral de El Artista: defensa del nuevo drama romántico».- Pilar Vega Rodríguez, «Geografía literaria en la prensa romántica: la cueva encantada».

\section{Revistas literarias españolas e hispanoamericanas (1869-1914), 16 (2014) Edición de Miguel Ángel Auladell}

R. Alarcón Sierra, «El periodismo finisecular de Ramiro de Maeztu».- Cecilio Alonso, «Noticia de "Plana del Lunes", suplemento literario de El Globo (1897-1898) - P. Bellido Navarro, «El más literato de todos los periodistas o el más periodista de todos los literatos: Mariano de Cavia en El Liberal. La retórica argumentativa de la serie "Plato del día"».- M. ${ }^{a}$ P. Celma Valero, «La crítica literaria en las revistas del fin de siglo como fuente historiográfica».- D. Chozas Ruiz-Belloso, «El Museo Universal pintado por sí mismo: trayectoria de un proyecto editorial (1857-1869).- A. Correa Ramón, «Melchor Almagro San Martín y sus colaboraciones en revistas literarias de su primera etapa (1896-1914)».- Ángeles Ezama, «Primeros datos sobre la presencia del reportero en la prensa española».- Marta Giné, "La recepción del teatro lírico extranjero en las crónicas teatrales de La Ilustración Española y Americana (1888-1898)».- J. M. González Soriano, «Miguel Moya y la revista La América (1879-1882).- Francisco Lafarga, «Literatura y literatos españoles en la revista Les 
Matinées Espagnoles (Madrid-París, 1883-1888)».- Ramón F. Llorens, «Las publicaciones para niños en el fin de siglo: un suplemento de El Liberal».- Christian Manso, «El Heraldo de París (1900-1904): poesía necesaria».- Margarita Merbilhaá, «El Nuevo Mercurio (1907) en el eje España/Francia/América».- D. Muela Bermejo, «La revista La Vida Literaria (1899) como reflejo de una nueva estética finisecular».- Marta Palenque, «Un diluvio de almanaques. Los almanaques de la prensa ilustrada: Blanco y Negro (1896-1900).- Ana María Risco, «Canto y desencanto del cisne. Rubén Dario en el diario El Orden de Tucumán (Argentina, 1898).- I. Rodríguez Moranta, «La República de las Letras (1905): entre el regeneracionismo y el republicanismo militante. Correspondencia inédita con Galdós».- Isabel Román, «Regeneracionismo y costumbrismo: los nuevos Españoles pintados por sí mismos del semanario España».- Jesús Rubio Jiménez, «La Ilustración de Madrid (18701871). Revista de transición del romanticismo al realismo.- M. ${ }^{a}$ Luisa Sotelo Vázquez, «Emilia Pardo Bazán en La España Moderna (1889-1910)».- Dolores Thion, «La revista Germinal, crisol de estéticas».- J. M. Vidal Ortuño, «Rescatar del olvido (Azorín en Blanco y Negro).- Carole Vinals, «Recursos literarios en la prensa de fin de siglo: función de la ironía y función de la sátira en La Ilustración Popular y Don Quijote (1893-1904). 



